\title{
Development of Biomass Gasification to Produce Substitute Fuels
}
R. J. Evans
R. A. Knight
M. Onischak
S. P. Babu

March 1988

Prepared by the Institute of Gas Technology for Pacific Northwest Laboratory under Contract DE-AC06-76RLO 1830 with the U.S. Department of Energy

Pacific Northwest Laboratory Operated for the U.S. Department of Energy by Battelle Memorial Institute 


\section{DISCLAIMER}

This report was prepared as an account of work sponsored by an agency of the United States Government. Neither the United States Government nor any agency thereof, nor Battelle Memorial Institute, nor any of their employees, makes any warranty, expressed or implied, or assumes any legal liability or responsibility for the accuracy, completeness, or usefulness of any information, apparatus, product, or process disclosed, or represents that its use would not infringe privately owned rights. Reference herein to any specific commercial product, process, or service by trade name, trademark, manufacturer, or otherwise, does not necessarily constitute or imply its endorsement, recommendation, or favoring by the United States Government of any agency thereof, or Battelle Memorial Institute. The views and opinions of authors expressed herein do not necessarly state or reflect those of the United States Government or any agency thereof, or Battelle Memorial Institute.

\section{PACIFIC NORTHWEST LABORATORY operated by \\ BATTELLE MEMORIAL INSTITUTE for the \\ UNITED STATES DEPARTMENT OF ENERGY under Contract DE-AC06-76RLO 1830}

\begin{tabular}{|c|c|}
\hline \multicolumn{2}{|c|}{ Printed in the United States of America } \\
\hline \multicolumn{2}{|c|}{$\begin{array}{c}\text { Available from } \\
\text { National }\end{array}$} \\
\hline \multicolumn{2}{|c|}{$\begin{array}{l}\text { National Technical Information Service } \\
\text { United States Department of Commerce }\end{array}$} \\
\hline \multicolumn{2}{|c|}{5285 Port Royal Road } \\
\hline \multicolumn{2}{|c|}{ Springfield, Virginia 22161} \\
\hline \multirow{2}{*}{\multicolumn{2}{|c|}{$\begin{array}{l}\text { NTIS Price Codes } \\
\text { Microfiche A01 }\end{array}$}} \\
\hline & \\
\hline \multicolumn{2}{|c|}{ Printed Copy } \\
\hline & Price \\
\hline Pages & Codes \\
\hline $001-025$ & $\mathrm{~A} 02$ \\
\hline $026-050$ & $\mathrm{~A} 03$ \\
\hline $051-075$ & $\mathrm{AO4}$ \\
\hline $076-100$ & $\mathrm{~A} 05$ \\
\hline $101-125$ & $A 06$ \\
\hline $126-150$ & A07 \\
\hline $151-175$ & $\mathrm{~A} 0 \mathrm{~B}$ \\
\hline $176-200$ & A09 \\
\hline $201-225$ & $\mathrm{~A} 010$ \\
\hline $226-250$ & A011 \\
\hline $251-275$ & $\mathrm{~A} 012$ \\
\hline $276-300$ & $\mathrm{~A} 013$ \\
\hline
\end{tabular}


PNL-6518

UC -245

DEVELOPMENT OF BIOMASS

GASIFICATION TO PRODUCE

SUBSTITUTE FUELS

R. J. Evans

R. A. Knight

M. Onischak

S. P. Babu

Institute of Gas Technology

Chicago, Illinois 60616

March 1988

Prepared by Institute of Gas Technology for Pacific Northwest Laboratory under Contract DE-AC06-76RLO 1830 with the U.S. Department of Energy

Pacific Northwest Laboratory Richland, Washington 99352 
EXECUTIVE SUMMARY

The development of an efficient pressurized, medium-Btu steam-oxygenblown fluidized-bed biomass gasification process was conducted at the Institute of Gas Technology (IGT), Chicago, Illinois, for Pacific Northwest Laboratory (PIN) of Richland, Washington, and the U.S. Department of Energy (DOE), Biofuel and Municipal Waste Technology Division, under Contract No. $B-C 5821-A-Q$. The overall program included initial stages of design-support research before the 12 ton-per-day (TPD) process research unit (PRU) was built. These stages involved the characterization of test-specific biomass species and the characteristics and limits of fluidization control. Also obtained for the design of the adiabatic PRU was information from studies with bench-scale equipment on the rapid rates of biomass devolatilization and on kinetics of the rate-controlling step of biomass char and steam gasification. The development program culminated with the successful operation of the PRU through 19 parametric-variation tests and extended steady-state processproving tests.

The test program investigated the effect of gasifier temperature, pressure, biomass throughput rate, steam-to-biomass ratio, type of feedstock, feedstock molsture, and fluidized-bed helght on gasification performance.

A long-duration gasification test of 3 days steady-state operation was conducted with whole tree chips to identify long-term effects of fluidized process conditions; to establish gasifier material and energy balances; to determine the possible breakthrough of low concentration organic species; and to evaluate the mechanical performance of the system components.

Test results indicate that the pressurized fluidized-bed process, which has proven to be simple to operate, can achieve carbon conversions of about $95 \%$ with cold gas thermal efficiencies of about $75 \%$ and with low oil and tar production.

New information was collected on the oil and tar fraction, which relate to the process operating conditions and feedstock type. The different feedstocks studied were very similar in elemental compositions, and produced similar product gas compositions, but each has a different distribution and character of the ofl and tar fractions. This information is important environmentally and would have an impact on the proper design of process clean-up equipment. 
Page

INTRODUCTION

$\begin{array}{ll}\text { PROGRAM OBJECTIVE AND SCOPE } & 3\end{array}$

PROGRAM TASK RESULTS $\quad 4$

Task I. Characterization of Biomass 4

$\begin{array}{ll}\text { Task II. Biomass Handling Characteristics - Pressurized } & 10 \\ \text { Fluidization Tests }\end{array}$

Equipment and Test Description 10

Experimental Test Results 12

$\begin{array}{ll}\text { Task III. Bench-Scale Experiments } & 18\end{array}$

Laminar-Flow Devolatilization Experiments $\quad 21$

Experimental Bench-Scale Test Results 24

Isothermal Char Gasification Experiments $\quad 34$

Maple Hardwood and Jack Pine Results 38

$\begin{array}{ll}\text { Corn Stover Results } & 48\end{array}$

Char Surface - Area Measurement $\quad 62$

Task IV. Process Research Unit Tests 65

Description of the Process Research Unit 66

$\begin{array}{ll}\text { Shakedown Testing } & 68\end{array}$

PRU System Proving Tests $\quad 69$

Parameter - Variation Tests $\quad 74$

Task V. Data Review for Scale-Up Tests $\quad 89$

Effect of Temperature $\quad 91$

Effect of Steam Feed Rate 96

Effect of Operating Pressure $\quad 96$

Effect of Feed Rate 99

$\begin{array}{ll}\text { Effect of Feedstock Type and Role of Steam } & 100\end{array}$

$\begin{array}{ll}\text { Effect of Bed Height } & 101\end{array}$

$\begin{array}{ll}\text { Effect of Moisture } & 101\end{array}$

$\begin{array}{ll}\text { Environmental Aspects } & 102\end{array}$

$\begin{array}{ll}\text { CONCLUSIONS } & 112\end{array}$

$\begin{array}{ll}\text { ACKNOWLEGMENTS } & 113\end{array}$ 
TABLE OF CONTENTS, Cont.

Page

REFERENCES CITED

114

APPENDIX A. Mechanical Design Drawings of the Process

Research Unit Test System

A-1

APPENDIX B. Description of PRU Instrumentation

B-1

APPENDIX C. PRU Experimental Procedures

C-1

Startup Procedure

C-3

Shutdown Procedure

$\mathrm{C}-4$

APPENDIX D. Description of Gas, Liquids, and Solids

Sampling System

$\mathrm{D}-1$

APPENDIX E. Summary of Material and Energy Balances for Individual Gasification Tests

$\mathrm{E}-1$

APPENDIX F. Properties of Entrained Solids

$\mathrm{F}-1$ 


\section{LIST OF FIGURES}

Figure No.

High-Pressure Fluidization Apparatus

Experimental Fluidization Curves for $-20+40$ Mesh Sand + Char at Elevated Pressure ( 87 psia) and Ambient Temperature

Fluidization as a Function of Pressure for a 20 Vol \% Char-Sand Mixture

Fluidization as a Function of Pressure for a 33 Vol \% Char-Sand Mixture

Fluidization as a Function of Pressure for a 50 Vol \% Char-Sand Mixture

Minimum Fluidization Velocity as a Function of Char Concentration at Two Pressures

Correlation for the Prediction of Minimum Fluidization Velocity

Schematic Flow Diagram of the Laminar-F1ow Reactor System

9 Devolatilization Yields as a Function of Temperature in $5 \% \mathrm{H}_{2}, 95 \% \mathrm{He}$, and in $100 \%$ Helium

Devolat1lization Yields as a Function of Temperature for Various Residence Times at 300 psig

Gas Specie Production as a Function of Temperature for Varlous Residence Times at 300 psig

Conversion Versus Temperature

Conversion as a Function of Reaction Zone Length for Various Temperatures at $300 \mathrm{psig}$

Schematic Flow Diagram for the Thermobalance Reactor System

Gasification of In-Situ Char From Maple Hardwood in $5 \% \mathrm{H}_{2}+45 \% \mathrm{He}+\overline{50 \% \mathrm{H}_{2} \mathrm{O}}$

Gasification of In-Situ Char From Maple Hardwood in $10 \% \mathrm{H}_{2}+40 \% \mathrm{He}+50 \% \mathrm{H}_{2} \mathrm{O}$ at 300 psig and at Different Temperatures

17 Gasification of In-Situ Char From Maple Hardwood

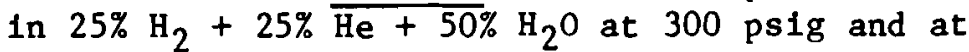
Different Temperatures 
LIST OF FIGURES, Cont.

Figure No.

Page

18

Gasification of In-Situ Char From Jack Pine in 5\% $\mathrm{H}_{2}+45 \% \mathrm{He}+50 \% \mathrm{H}_{2} \mathrm{O}$ at $300 \mathrm{psig}$ and at Different Temperatures

Gasification of In-Situ Char From Jack Pine in $10 \%$ $\mathrm{H}_{2}+40 \% \mathrm{He}+50 \% \mathrm{H}_{2} \mathrm{O}$ at 300 psig and at Different Temperatures

Gasification of In-Situ Char From Jack Pine in $25 \%$ $\mathrm{H}_{2}+25 \% \mathrm{He}+50 \% \mathrm{H}_{2} \mathrm{O}$ at $300 \mathrm{psig}$ and at Different Temperatures

Gasification of Maple Hardwood Char in Gas Mixture at a Pressure of 300 psig and at Different Temperatures First-Order Plot

Gasification of Maple Hardwood Char in Different Gas Media - Arrhenius Plot

Gasification of Jack Pine Char in Different Gas Media Arrhenius Plot

Gasification of In-Situ Char From Densified Corn Stover at $1300^{\circ} \mathrm{F}$ and at a Pressure of 300 psig With Different Reaction Gas Media

Gasification of In-Situ Char From Densified Corn Stover at $1400^{\circ} \mathrm{F}$ and at a Pressure of $300 \mathrm{psig}$ With Different Reaction Gas Media

Gasification of In-Situ Char From Densified Corn Stover at $1500^{\circ} \mathrm{F}$ and at a Pressure of $300 \mathrm{psig}$ With Different Reaction Gas Media

Gasification of In-Situ Char From Densified Corn Stover at 300 psig With Different Reaction Gas Media

Gasification of In-Situ Char From Densified Corn Stover With $50 \% \overline{\mathrm{H}_{2} \mathrm{O}, 5 \%} \mathrm{H}_{2}$, and $45 \%$ He at a Pressure of 300 psig and at Different Temperatures Limitations of First-Order Fit $5 \% \mathrm{H}_{2}+45 \% \mathrm{He}+50 \% \mathrm{H}_{2} \mathrm{O}$ at 300 psig and at Different Temperatures $1500^{\circ} \mathrm{F}$ and at a Pressure of $300 \mathrm{psig}$ in a Gas Mixture Containing $5 \% \mathrm{H}_{2}, 45 \% \mathrm{He}$, and $50 \% \mathrm{H}_{2} \mathrm{O}$ 
Comparison of the Gasification Rates of Jack Pine, Maple Hardwood, and Corn Stover In-Situ Chars With Peat and Bituminous Coal Chars

Isometric View of PRU Equipment Layout

Chronology of Selected Process Control Parameters During Test T3D-1

Oxygen Required as a Function of Gasification Temperature

Feed Carbon Conversion as a Function of Gasification Temperature

Product Gas Composition as a Function of Gasification Temperature

Gas Yleld and Heating Value as a Function of Temperature

Effect of Steam on Product Gas Composition (Whole Tree Chips From Pennsylvania) 
2 Density and Ash Fusion Temperatures of Some Biomass Species

Proximate and U1timate Analyses of Corn Stover

Analyses of Corn Stover for Cellulose, Hemicellulose, and Lignin

Summary of Laminar-Flow Devolatilization Data

Material Balances for Laminar-Flow Devolatilization Data

Reaction Rate Constant for the Gasification of Maple Hardwood and Jack Pine Char in Steam-Hydrogen-Helium Mixtures

Apparent Activation Energy for the Gasification of Maple Hardwood and Jack Pine Char in Steam-Hydrogen-Helium Mixtures

The Values of Kinetic Parameters for the Gasification of In-Situ Char From Densified Corn Stover in Different Media

The Values of the Kinetic Parameters for the Gasification of Stabilized Chars From Corn Stover in $50 \% \mathrm{H}_{2} \mathrm{O}, 5 \% \mathrm{H}_{2}$, and $45 \%$ He at Different Temperatures

Surface Areas and Total Open Pore Volumes of Maple Hardwood Char

Summary of Sysțem Proving Test Results 


\section{INTRODUCTION}

The Institute of Gas Technology (IGT), began the investigation of a pressurized, steam-oxygen blown, fluidized-bed gasification process to produce medium-Btu gas or a synthesis gas from biomass in May 1980. A technical report for the period ending June 1981 was submitted to DOE $^{1}$ and it contains laboratory and bench-scale data on various biomass species, leading to the design of a process research unit (PRU).

This final report contains the continuation of the same investigation and covers the period from June 1981 through December 1986. It includes additional areas of the bench-scale investigation to define design data for the PRU. The PRU is described and the results from shakedown operations to parametric process variable tests and long-duration operation are presented. The overall program plan is described by the following program objective and scope statement followed by the task description.

The program was divided into three phases. In Phase I we acquired design information from bench-scale experimental tests and cold-flow fluidization model tests. This information was used in Phase II to design a 12-TPD adiabatic process research and development gasification system. Phase III required construction and operation of the PRU over a variety of parameters to generate adiabatic design information for process evaluation and optimization. A long-duration test lasting for 3 days of steady-state operation was also completed.

The selection of a fluidized-bed gasifier filled with inert media offers many advantages for biomass gasification. The small alumina spheres used in the PRU offer uniform fluidization over the entire range of biomass feedrates. Biomass feed size can range from sawdust to pulpwood-sized chips.

The high heat capacity of the inert media along with its circulation most efficiently distributes the heat energy from the combustion fraction to the endothermic gasification reactions of the incoming biomass, while the low bulk density biomass char is retained in the gasifier and reduced in size exposing more char reaction surface area. The 3 to 5 minutes of biomass residence time in the fluidized-bed gasifier and the overall gas residence in the gasifier and overhead freeboard contribute to the high carbon conversion and the low oll and tar production demonstrated in the PRU tests. 
Pressurized operation makes the fluidization gas bubbles smaller and therefore the fluidization is smoother than at atmospheric pressure. Producing gas at elevated pressure is required to overcome piping losses and pressure drop through filters or other gas cleanup equipment for pipeline distribution. Pressurized gasification also contributes to improving the process efficiency for synthesis gas process applications such as methanol or ammonia production. 


\section{PROGRAM OBJECTIVE AND SCOPE}

The objective of this project was to develop an efficlent blomass gasification process to produce medium-Btu gas sultable for an Industrial fuel gas or for upgrading to substitute natural gas (SNG) or synthesis gas.

The project involved the development of a pressurized, single-stage, oxygen-blown fluidized-bed gasifier for the thermal gasification of biomass fuels. Fundamental information on the simultaneous physical and chemical processes occurring in biomass fluidized-bed gasification was needed for the rational design and scale-up of the process.

The overall program Included bench-scale experiments that led to the design and construction of the PRU. Gasification tests were conducted in the 11.5-1nch-ID fluidized-bed gastfier and new data were obtained on biomass gasification characteristics as a function of significant operating parameters at continuous, adiabatic, steady-state operating conditions and on a large scale (up to 12 TPD).

The 11.5-inch-ID PRU was designed for maximum operational flexibility in the areas of -

a. Operating pressure, atmospheric to 500 psig

b. Operating temperature, up to $1800^{\circ} \mathrm{F}$

c. Fluidized-bed heights, up to 8 feet for L/D ratios from 2 to 8

d. Biomass feed inlet locations 6 to 24 inches above the oxidant distributor.

Critical areas in which design information was incomplete were planned for evaluation; Including high-pressure feeder operation, the effect of operating parameters on adiabatic gasifier performance, and the characteristics of process effluents.

The experimental PRU test program addressed these areas and quantifled the gasification performance. The performance trends that were found as a function of primary operating variables identified approaches for system optimization and indicated the requirement for various upstream and downstream process equipment modifications or modified operating procedures. This data can be used in the process assessment and evaluation of the economics of pressurized fluidized-bed biomass gasification applications. 
PROGRAM TASK RESULTS

The program was divided into the following five tasks:

Task I. Characterization of Biomass

Task II. Blomass Hand11ng Characteristics

Task III. Bench-Scale Experiments

Task IV. Process Research Un1t Tests

Task V. Data Review for Scale-Up Tests.

Task I. Characterization of Biomass

Representative samples of selected large resource materials from the Midwest were obtained for characterization and tests. These included forest residues from both hardwood and softwood trees and corn stover as an agricultural residue. Samples were requested from sources that could supply materlal in quantities of 20 tons or greater.

Each selected biomass material was characterized by standard tests of physical and chemical properties because of the interrelationships between these properties, gasification reactivity, and fluidization. The physical properties of interest included density and particle size; significant chemical properties of interest included proximate and ultimate analysis, calorific value, ash constituents, and ash fuston characteristics. The tests were also used to characterize the chars formed from the blomass materials, which have direct relation to gasifier design and operation. The standard tests and procedures that were used to characterize the chemical and physical properties of the biomass materials are Identified in Table 1.

The characteristics of a maple hardwood, Douglas-fir hog fuel, jack pine softwood, and undensifled corn stover were determined and presented in a previous report. 2

The ash fusion characteristics in both reducing and oxidizing atmospheres along with the particle and bulk densities for Douglas-fir hog fuel, maple hardwood, jack pine softwood, and corn stover were determined and reproduced in Table 2 for discussion continutty.

The characteristic ash fusion temperatures measured for the jack pine ash are lower than those for the maple hardwood ash, but simflar to the results 
Table 1. STANDARD CHARACTERIZATION TESTS

Chemical Tests

Ultimate analysis

Proximate analysis

Ash analysis

Heating value

Cellulose and hemicellulose

Acid insoluble lignin

Physical Tests

Moisture

Ash fusion analysis

Low-temperature ashing

High-temperature ashing

Particle size analysis

Particle density

Bulk density

Surface areas by nitrogen and carbon dioxide adsorption

Mercury and helium particle densities for porosity
Standard Procedure

ASTM ${ }^{*}$ D3176-74 or "Perkin-Elmer" 240 method

ASTM 3175

ASTM D1102-56 or TAPPI** T1505-58

ASTM D2015

TAPPI 53(2):257-261 (Feb. 1970)

TAPPI T222 05-74

Standard Procedure

ASTM D2016-74

ASTM D1857

IGT standard procedure

ASTM D3174-73

ASTM D431

IGT standard procedure

IGT standard procedure

IGT standard procedure

IGT standard procedure

* ASTM is the American Society for Testing and Materials.

** TAPPI is the Technical Association of the Paper and Pulp Industry.

$171 / 65058 \mathrm{fr}-\mathrm{t} / \mathrm{RPP}$ 
Table 2. DENSITY AND ASH FUSION TEMPERATURES OF SOME BIOMASS SPECIES

\begin{tabular}{|c|c|c|c|c|c|c|c|}
\hline \multirow{2}{*}{\multicolumn{2}{|c|}{$\begin{array}{l}\text { Douglas-Fir Hog Fuel } \\
\text { Particle }\end{array}$}} & \multicolumn{2}{|c|}{ Maple Hardwood } & \multicolumn{2}{|c|}{ Jack Pine Softwood } & \multicolumn{2}{|c|}{ Corn Stover } \\
\hline & & Particle & Bulk & Particle & Bulk & Particle & Bu1k \\
\hline \multicolumn{8}{|c|}{ - Density, $1 \mathrm{~b} / \mathrm{ft}^{3} \quad \ldots$} \\
\hline 42.4 & 13.1 & 38.0 & 10.0 & 37.0 & 15.1 & 36.2 & 7.9 \\
\hline 45.6 & 18.1 & 51.8 & 11.1 & 48.0 & 16.3 & 62.4 & 17.1 \\
\hline 26.9 & 9.3 & 38.7 & 7.9 & 20.0 & 5.7 & 21.2 & 6.6 \\
\hline 37.3 & 9.4 & 41.8 & 9.2 & 35.6 & 6.5 & 70.5 & 21.3 \\
\hline \multicolumn{8}{|c|}{ Ash Fusion Temperatures, ${ }^{\circ} \mathrm{F}$} \\
\hline Reducing & Oxidizing & Reducing & Oxidizing & Reducing & Oxidizing & Reducing & Oxidizing \\
\hline 2070 & 2150 & $2700+$ & $2700+$ & 1950 & 2020 & 2250 & 2330 \\
\hline 2195 & 2295 & $2700+$ & $2700+$ & 2150 & 2620 & 2700 & $2700+$ \\
\hline 2335 & 2480 & $2700+$ & $2700+$ & $2190+$ & 2680 & $2700+$ & $2700+$ \\
\hline 2470 & 2665 & $2700+$ & $2700+$ & 2280 & $2700+$ & $2700+$ & $2700+$ \\
\hline
\end{tabular}

$171 / 65058 \mathrm{fr}-\mathrm{t} / \mathrm{RPP}$ 
for Douglas-fir hog fuel. The density values for the jack pine char are lower than the maple hardwood and Douglas-fir hog fuel char values, whereas the density values for the alr-dried samples of the three woody species are very similar.

A sample of corn stover densified into approximate 1.25-inch cubes was obtained from Professor John Goss at the University of California at Davis. The corn stover came from a California harvest, and the densification process did not use any binder additive. The bulk density of the cubes as-received was measured as $77.21 \mathrm{~b} / \mathrm{ft}^{3}$.

Characterization tests of the corn stover were completed in this program for certain smaller size fractions and are reported in Tables 3, 4, and 5. These are compared with the characterization test results of the undensified corn stover from an Illinois harvest in a similar size fraction. These tables highlight the differences between a densified material and a non-densified material.

Table 3. PROXIMATE AND ULTIMATE ANALYSES OF CORN STOVER

\begin{tabular}{|c|c|c|c|c|}
\hline & \multicolumn{2}{|c|}{ Corn Stover } & \multirow{2}{*}{$\begin{array}{l}\frac{\text { Densified }}{A s-} \\
\text { Recelved } \\
\end{array}$} & \multirow{2}{*}{$\begin{array}{r}\text { Corn Stover } \\
\text { Dry } \\
\end{array}$} \\
\hline Proximate Analysis, wt \% & $\begin{array}{c}\text { As- } \\
\text { Recelved } \\
\end{array}$ & Dry & & \\
\hline $\begin{array}{l}\text { Molsture } \\
\text { Volatile Matter } \\
\text { Fixed Carbon } \\
\text { Ash Total }\end{array}$ & $\begin{array}{r}5.0 \\
74.2 \\
13.8 \\
7.0 \\
100.0\end{array}$ & $\begin{array}{r}78 . \overline{-} \\
14.5 \\
7.4\end{array}$ & $\begin{array}{r}5.9 \\
60.1 \\
13.7 \\
20.3 \\
100.0\end{array}$ & $\begin{array}{l}-- \\
63.9 \\
14.6 \\
21.5\end{array}$ \\
\hline Ultimate Analysis, wt \% & Dry & Daf & Dry & Daf \\
\hline $\begin{array}{l}\text { Carbon } \\
\text { Hydrogen } \\
\text { Nitrogen } \\
\text { Sulfur } \\
\text { Oxygen (by diff.) } \\
\text { Ash Total }\end{array}$ & $\begin{array}{r}46.50 \\
5.81 \\
0.56 \\
0.11 \\
39.67 \\
7.35 \\
100.00\end{array}$ & $\begin{array}{r}50.20 \\
6.27 \\
0.60 \\
0.12 \\
42.82 \\
-\end{array}$ & $\begin{array}{r}37.80 \\
4.84 \\
0.65 \\
0.09 \\
35.05 \\
21.57 \\
100.00\end{array}$ & $\begin{array}{r}48.20 \\
6.17 \\
0.83 \\
0.11 \\
44.69 \\
--\end{array}$ \\
\hline Heating Value, Btu/lb & 8167 & & 6231 & \\
\hline
\end{tabular}

According to the proximate and ultimate analyses, the densified corn stover composition is very similar to the undensified material, except for the amount of volatile matter and ash. The densification process may have reduced 
Table 4. DENSITY AND ASH FUSION TEMPERATURES OF CORN STOVER

Material

$\frac{\text { Corn Stover }}{\text { Particle }} \frac{\text { Bulk }}{-}, \frac{\text { Densified Corn Stover }}{\text { Particle }}$

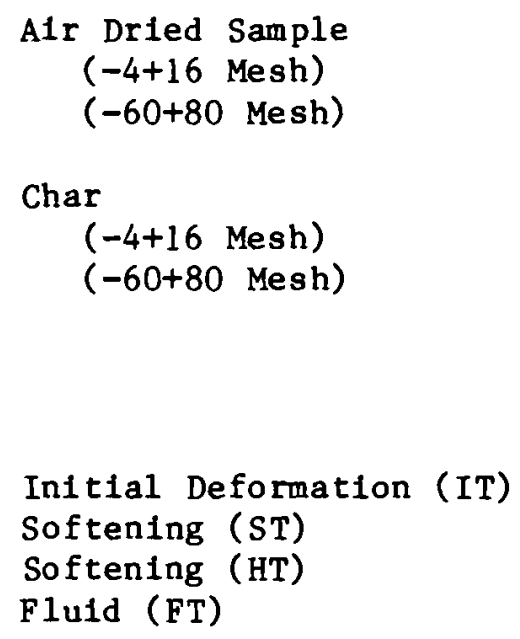

Initial Deformation (IT)

Sof tening (ST)

Softening (HT)

Fluid (FT)

$$
21.2
$$

6.6

21.3

45.6

66.2

12.1

70.5

Ash Fusion Temperatures, ${ }^{\circ} \mathrm{F}$

Reduction

Oxidizing

Reducing

Oxidizing

$\begin{array}{ll}2250 & 2330 \\ 2700 & 2700+ \\ 2700+ & 2700+ \\ 2700+ & 2700+\end{array}$

2100

2170

2270

2450

2300

$>2550$

Table 5. ANALYSES OF CORN STOVER FOR CELLULOSE, HEMICELLULOSE, AND LIGNIN

\begin{tabular}{lr}
\multicolumn{2}{c}{ Material } \\
\hline Corn Stover & Dens1fied Corn Stover \\
$(-12+16$ Mesh $)$ & wt\% (dry) $-12+16$ Mesh $)$ \\
\hline-
\end{tabular}

Composition of Blomass

Materials
Cellulose
Hemicellulose
Acid-Insoluble Lignin
Ash
Unaccounted-for Extractives

36.8

32.6

25.4

23.6

16.9

13.6

7.4

21.6

13.5

8.6

Distribution of Structural Consti tuents

Cellulose
Hemicellulose
Acid-Insoluble Lignin

46.5

46.7

32.1

33.8

21.4

19.5 
the volatile matter and also the heating value. No sample of the undensiffed California batch was avallable for testing to measure the volatile matter before densification. The ash content differences in these samples can reflect local collection and preparation procedures and are expected to vary widely among various samples.

The particle and bulk densities reported in Table 4 for various screen sizes for both densifled and undensifled ground materlal indicate some variation in values, espectally in the larger size fraction. The handling, fluidization, and reaction characteristics could be affected by the differences in composition and density.

The various ash fusion temperatures for the densified and undensified corn stover samples are also compared in Table 4. The measured temperatures for the densified corn stover sample from the Californla harvest are lower than those for the undensified sample from the Illinots harvest. This could possibly result from different ash constituents and amounts in each sample.

Table 5 presents the structural constituents of the two corn stover materials. The values of the three major constituents are similar, but somewhat lower for the densified material. Whether this is related to the lower amount of volatile matter measured for the densified material can only be answered by analyzing the undensified corn stover batch.

Additional tests were made on the samples of maple hardwood char that were prepared for the Task III bench-scale tests of char gasification rates. The surface areas and total pore volume were measured to determine if there was an effect on gasification rates from the physical structure of the chars and/or their reactivity. The results of these measurements and the discussion are presented in the Task III section.

The information on the physical and chemical characteristics of each biomass species and its char developed in this task has been cataloged for process design purposes. As an example, the ash content of a species and the corresponding ash fusion temperatures can have an impact on gasifier design and operation. The PRU gasifier was designed to entrain ash with the raw product gases; therefore, the ash Inventory in the bed is maintained low and ash sintering is minimal, especially with a properly designed oxygen distributor. Also, knowledge about the characteristics or behavior of 
specific particle size fractions is important in interpreting bench-scale experimental results, which could have significant process design consequences if properties are not uniform.

Task II. Biomass Handling Characteristics - Pressurized Fluidization Tests

The results of the cold model fluidization tests that were conducted at atmospheric pressure to determine the fluidization behavior of various mixtures of wood char and inert materials were presented in a previous report ${ }^{2}$, as were the results of an investigation of the effect of various gas distributor nozzle designs on gas jet penetration into a fluidized bed. That work showed that the measured minimum fluldization velocities were lower for the mixtures of char and inert materials than for the inert materials alone. The inert materlals reduced slugging and improved the fluidization. Furthermore, the fluidization characteristics of the mixtures were quite constant over a large range of char concentration in the fluidized bed. Hence, smooth fluidization behavior is expected over a large range of char inventory in the bed.

Tests of steam-oxygen distributor nozzle sizes and patterns provided Information on stable, controlled jet penetration lengths into the fluidized bed as a function of gas jet velocity, the fluldized-bed superficlal gas velocity, and the nozzle layout pattern.

This program report presents the results of fluidization tests that were conducted at an elevated pressure and ambient temperature to simulate the increased density of the fluidizing gas that would be in the gasifier at the selected baseline process operating conditions of $1500^{\circ} \mathrm{F}$ and $300 \mathrm{psig}$.

The purpose of these pressurized fluidization tests was to determine the effect of the fluidizing-gas density on the fluidization behavior of the low bulk-density wood char and of mixtures of char with inert materials. The gas density in the steam-oxygen gasification PDU at $1500^{\circ} \mathrm{F}$ and $300 \mathrm{psig}$ was estimated at about $0.4 \mathrm{lb} / \mathrm{ft}^{3}$; this density was simulated in the ambienttemperature $\left(80^{\circ} \mathrm{F}\right.$ ) fluidization tests by operating at 87 psia pressure.

\section{Equipment and Test Description}

The pressurlzed fluldization tests were conducted with an $11.5-1$ nch-ID Plexiglas column enclosed in a 3-foot-OD steel pressure vessel as indicated in Figure 1. The pressures inside and outside the clear plastic column were 


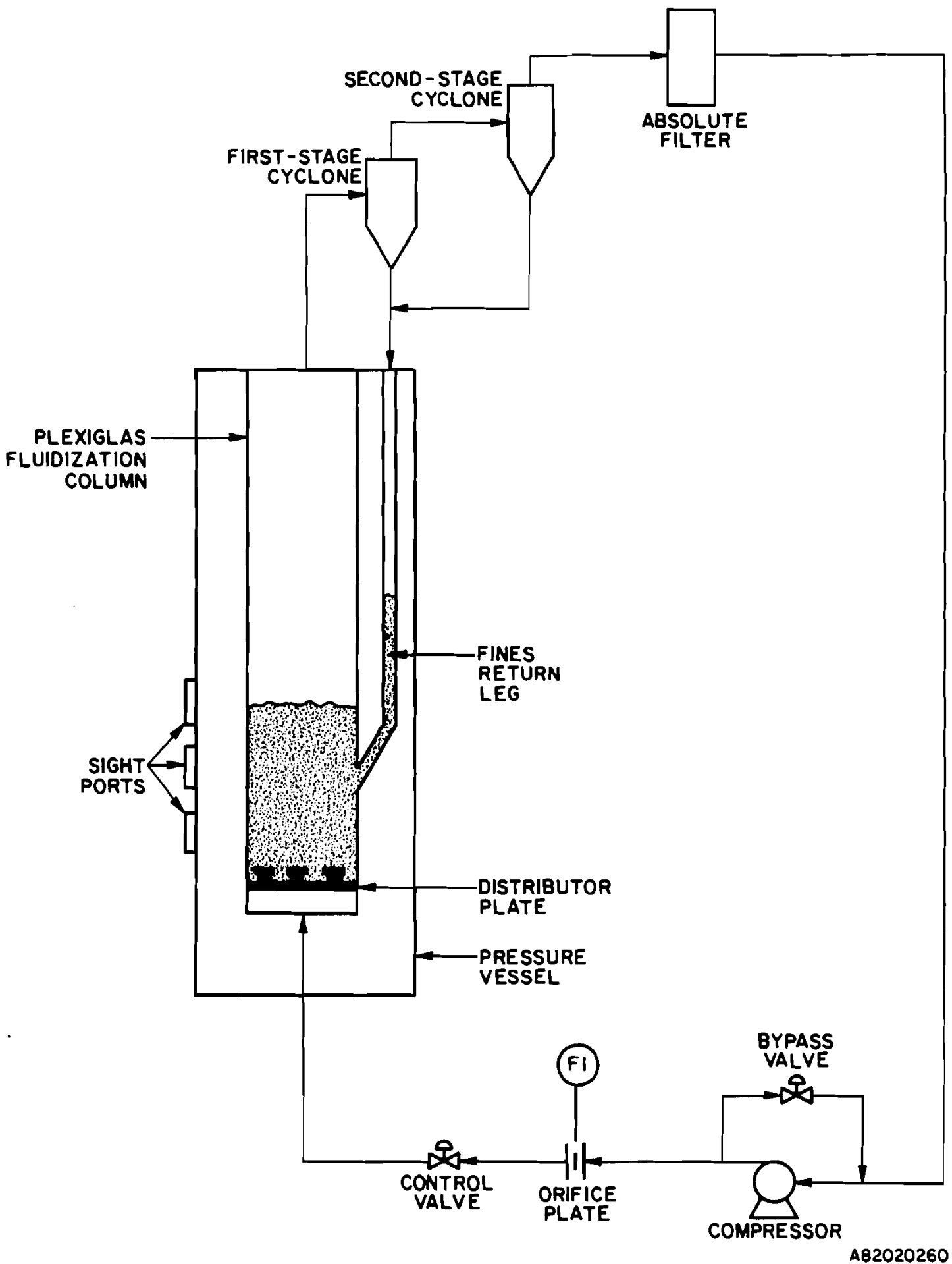

Figure 1. HIGH-PRESSURE FLUIDIZATION APPARATUS 
balanced and had the capability to be raised up to 300 psig for a fluldization test. Viewports in the steel pressure vessel shell permitted observation of the fluidization characteristics of the bed materials. The remainder of the equipment consisted of a compressor for the fluidizing gas, two cyclones, and an absolute filter. The fluidization gas was recirculated, flowing through the cyclones and filter before returning to the compressor. The fines collected in the cyclones were returned to the bed.

In a typical test run, solids were loaded into the column to a bed height of about 5 feet. The unit was then pressurized. After the gas reached the test pressure, it was directed at a low flow rate to the gas distributor. The initial flow rate was about $5 \%$ to $10 \%$ of the maximum test flow, as determined by an orifice meter. The column was given 4 to 5 minutes to reach an equilibrium, and then the gas flow was increased in increments of $5 \%$ to $10 \%$ over the range of test flow rates. For the pressurized fluidization tests, mixtures of sand $(-20+40$ U.S. sleve size) and hardwood char $(-1 / 4$ inch) were used. Sandchar mixtures of $20 \%, 33 \%, 40 \%$, and $50 \%$ char by volume were tested (in add $1-$ tion to pure char). The gas distributor plate installed in the test apparatus had a bubble cap type of design. The fluidizing gas in all tests was

nitrogen. All of the tests reported here were conducted at 87 psia and $80^{\circ} \mathrm{F}$.

Experimental Test Results

The measured values of the minimum fluidization velocity, $u_{m f}$, and the corresponding pressure drop per unit length or bed density for each char concentration tests are presented in Table 6. The atmospheric fluidization test results are also listed for comparison. Figure 2 shows the bed density variation with the superficial fluidization gas velocity at the elevated pressure. Figures 3 through 5 compare the fluldization runs conducted at 15 psia with the runs conducted at 87 psia.

As shown in Figures 3 through 5 , the minimum fluidization velocity, $u_{\text {mf }}$, in all cases is lower for the pressurized fluidization tests. This is expected because the drag force becomes greater as the density of the fluidizing gas increases. As a result, fluidization occurs at a lower superficlal gas velocity. The bed density values $\Delta \mathrm{P} / \mathrm{L}$, appear somewhat lower for the higher pressure tests if extrapolated to the higher superficial gas velocities. This is not expected; however, a possible explanation may arise from variances in the pressurized and atmospheric pressure test equipment, 


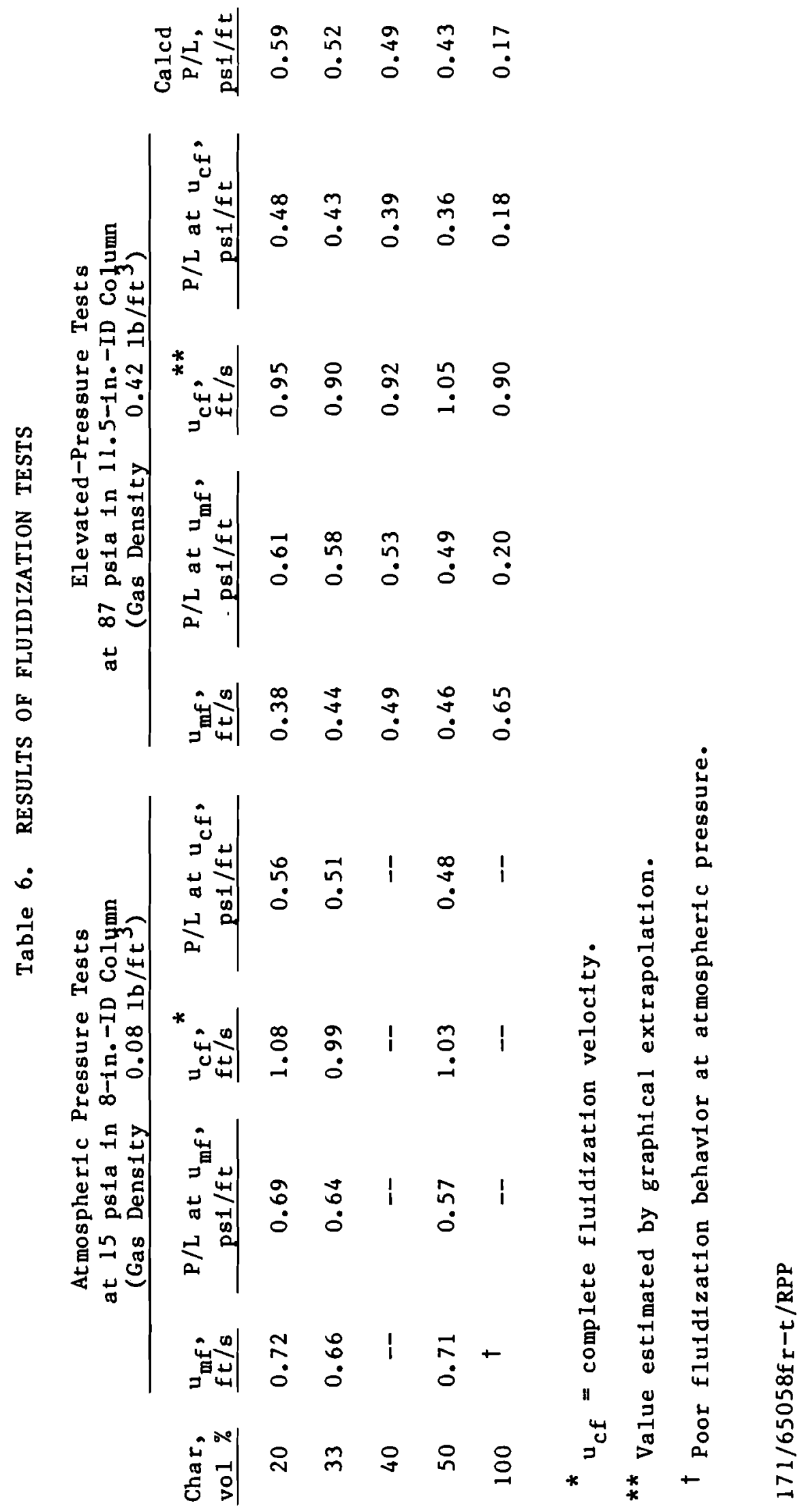

$\begin{array}{llllllllllllllllllllll}\text { I N S S } & T & \text { I } & T & U & T & E & O & F & G & A & S & T & E & C & H & N & O & L & O & G & Y\end{array}$ 


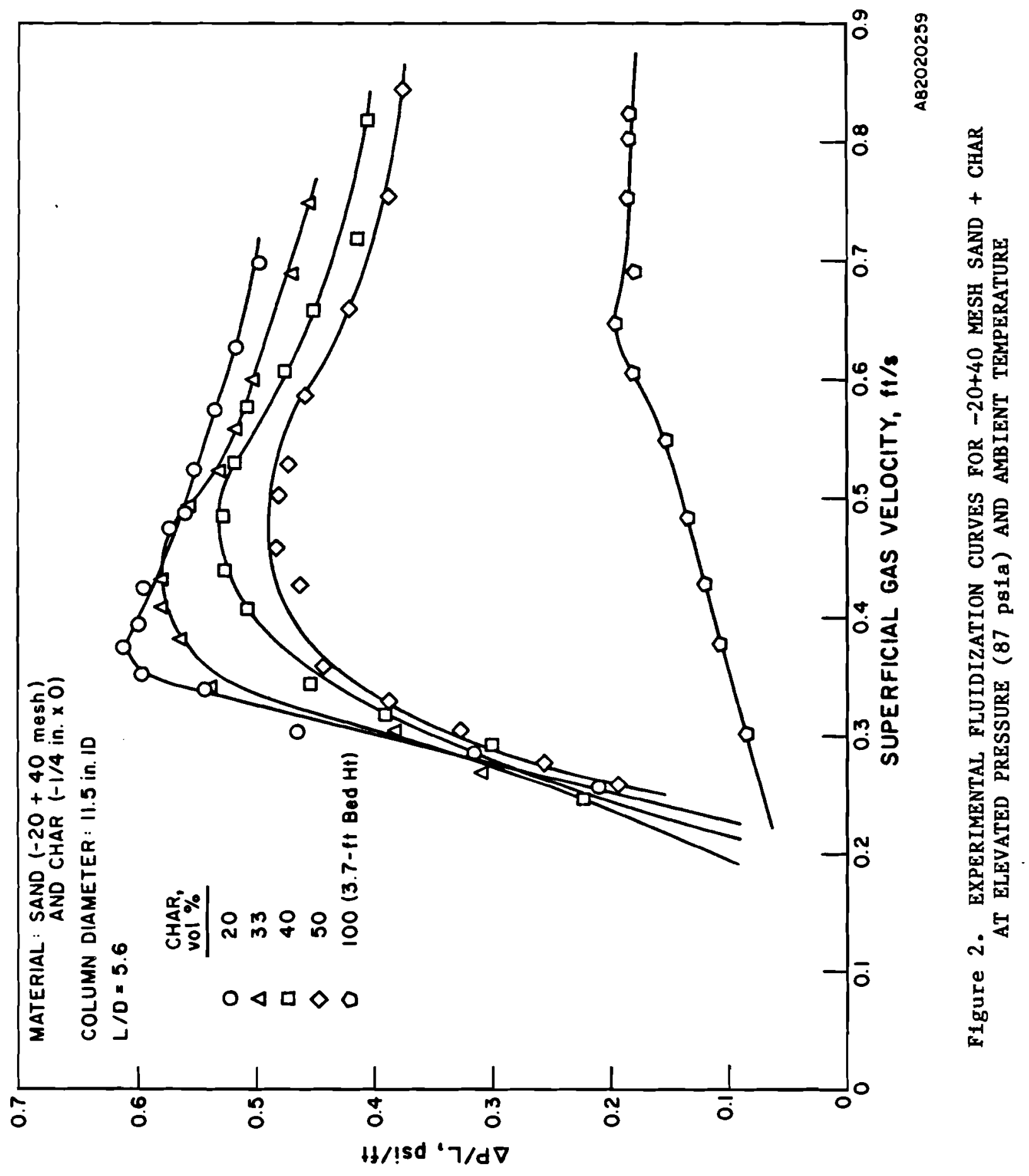




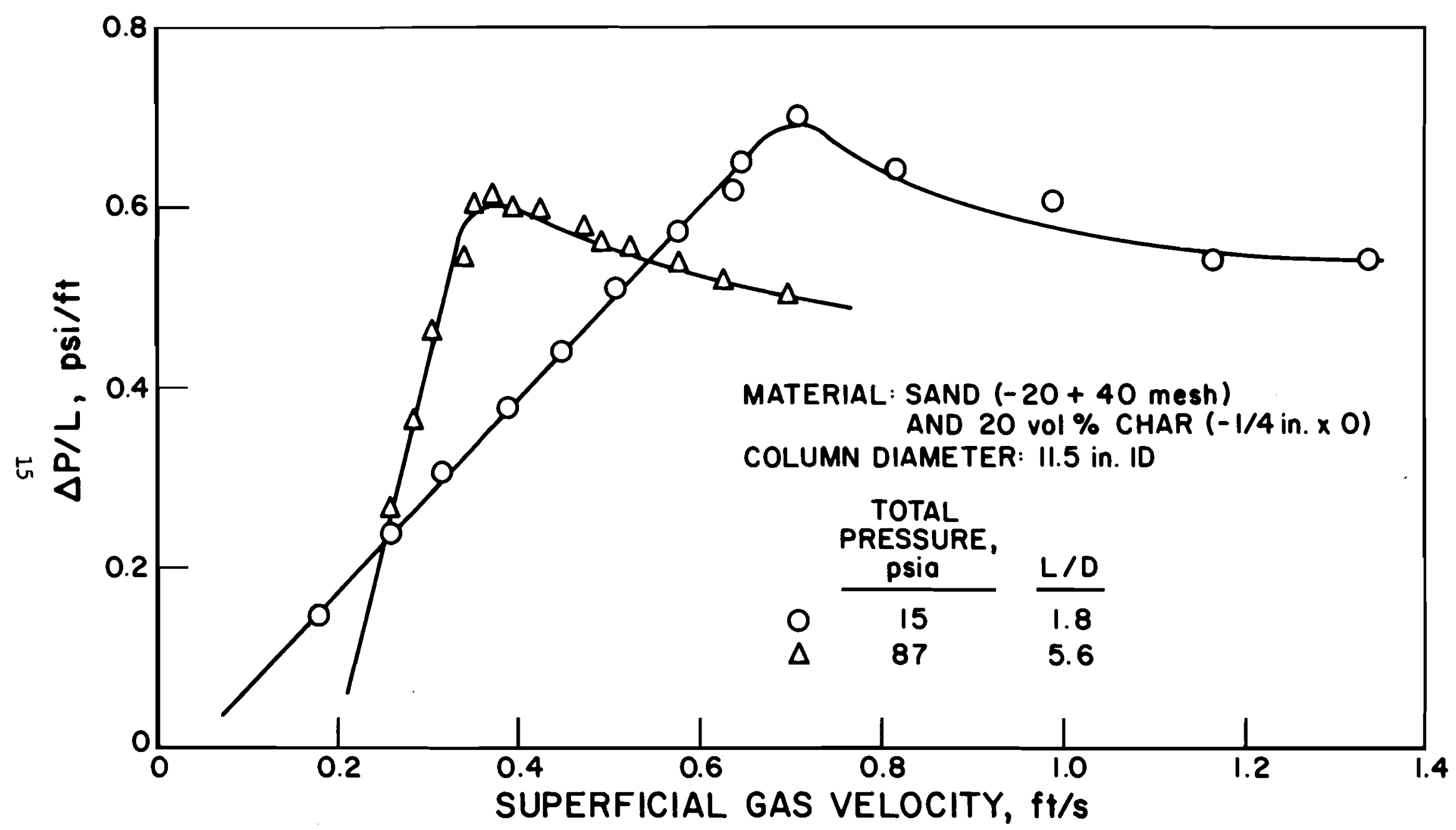

A82020261

Figure 3. FLUIDIZATION AS A FUNCTION OF PRESSURE FOR A

20 vo1 \% CHAR-SAND MIXTURE 


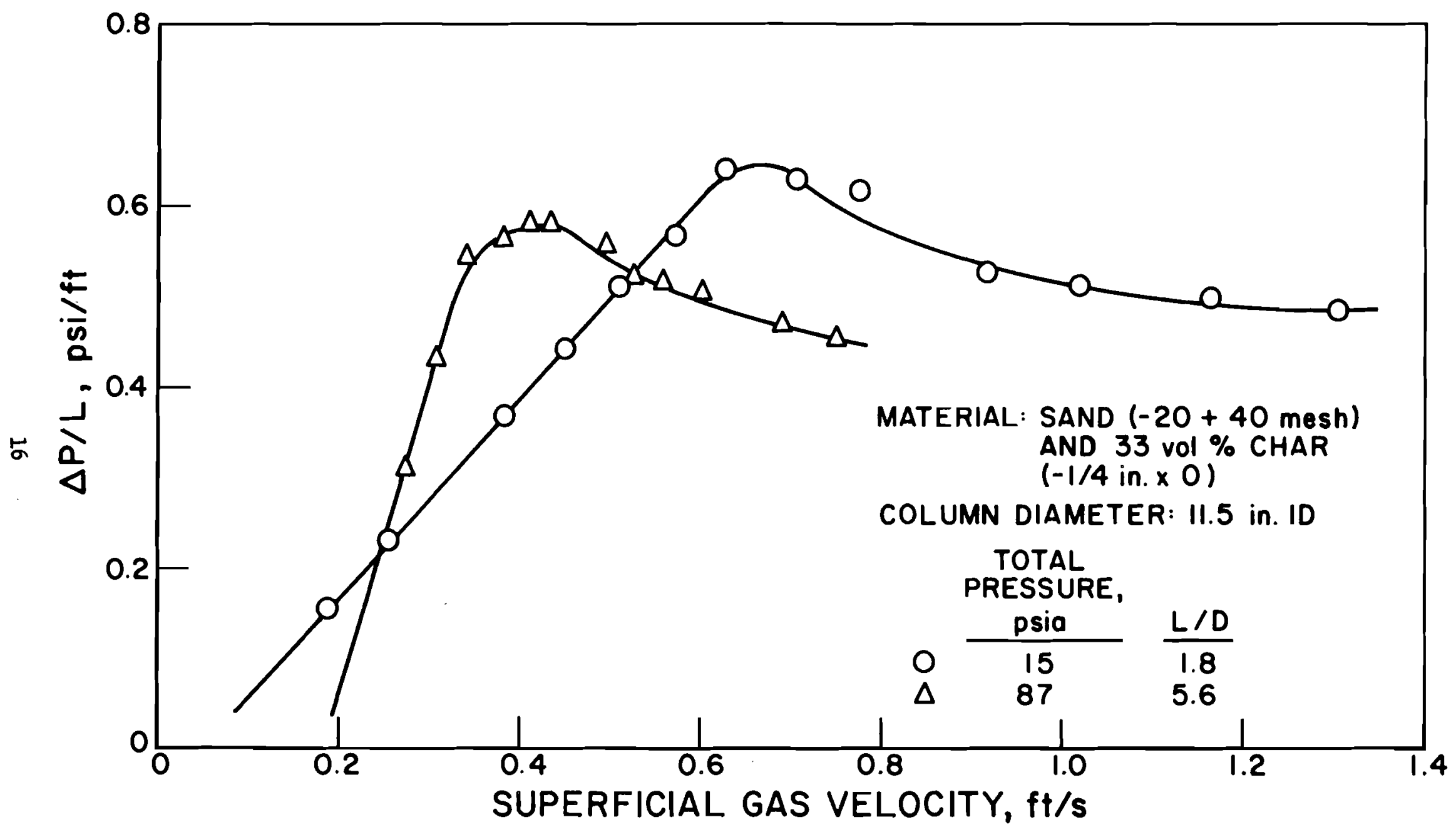

Figure 4. FLUIDIZATION AS A FUNCTION OF PRESSURE FOR A 33 vo1 \% CHAR-SAND MIXTURE 


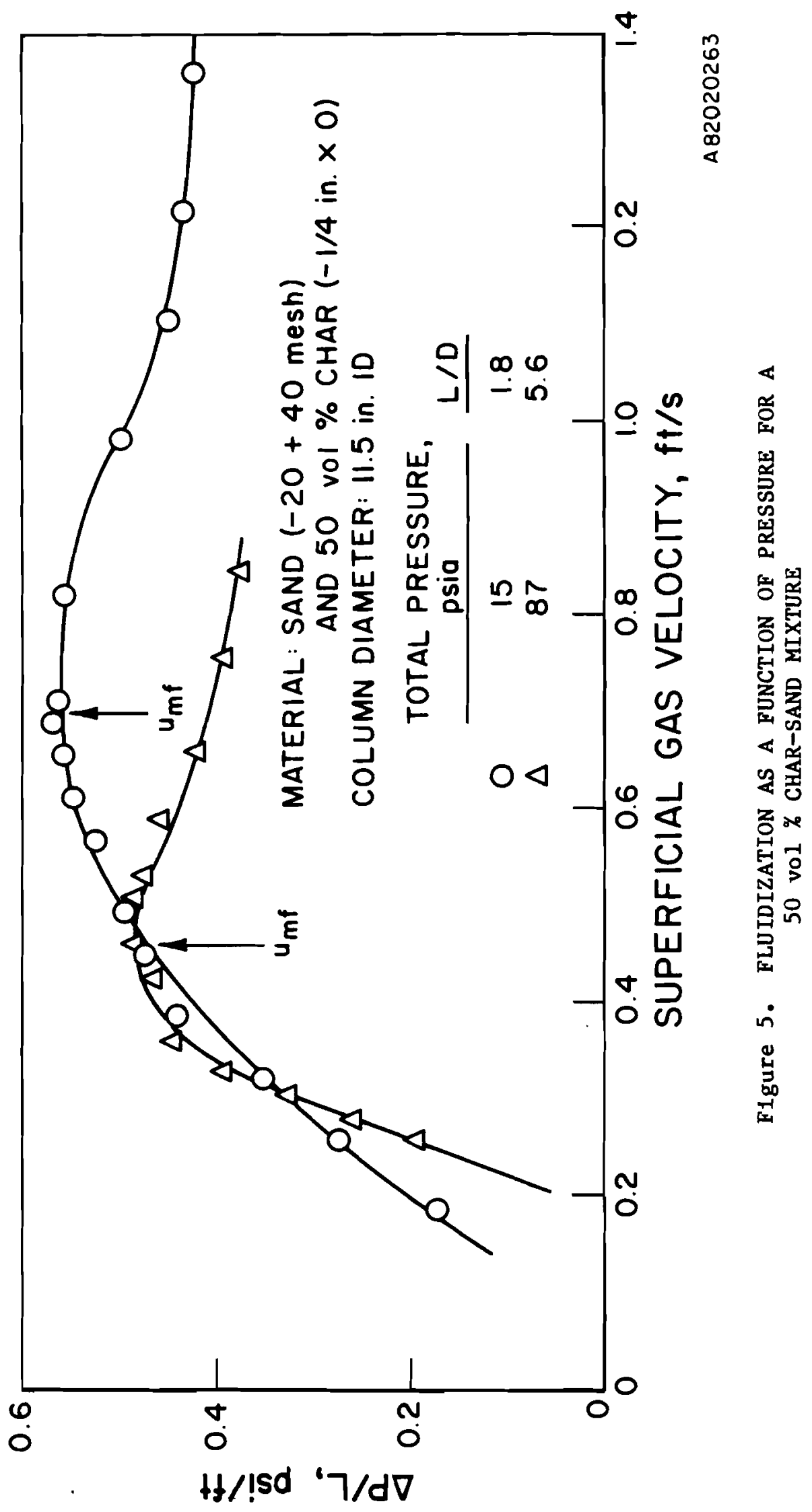


because the difference appears as a constant value of about $0.08 \mathrm{ps} 1 /$ foot, independent of the char concentration. The atmospheric pressure tests compared here were conducted in an 8-inch-ID column where wall effects could possibly be contributing to the measured pressure drop.

Figure 6 presents the relationsh1p between the minimum fluidization velocity and char concentration. As with the atmospheric fluidization tests, there appears to be a range of char inventory in the bed where the value of $u_{\mathrm{m} f}$ is approximately constant, providing a steady fluidization behavior.

One significant difference in behavior was observed during the pressurized fluidization tests. The mixtures with higher char concentrations were more easily fluidized at this elevated pressure or simulated gas density than in the atmospheric fluldization tests conducted earlier. In those tests, the mixtures with high char concentrations fluldized, but still showed a slugging tendency. In these pressurized tests, even a bed with $100 \%$ char was fluldized with no tendency to slug. The values from the $100 \%$ char test agree with the published correlation as shown in Figure 7 for both the 8-1nch-ID column at atmospheric pressure and the 11.5-1nch-ID column at 87 psia. Task III. Bench-Scale Experiments

The conversion of blomass to produce a medium-Btu gas can be divided into the following steps:

- Devolatilization - the nearly instantaneous thermal decomposition of blomass, followed by a gas-phase hydrogenation of volatile products into hydrocarbon gases. Hydrogen, carbon oxides, 11ght hydrocarbons, and water are the primary products of devolatilization.

- Char Gasification - a slow gasification of residual biomass char with steam in the presence of hydrogen to produce methane, carbon monoxide, hydrogen, and carbon dioxide.

- Char Combustion - the combustion of residual biomass char, which supplies the energy required for the endothermic char gasification reactions.

The bench-scale experimentation was conducted to investigate these first two reaction steps with maple hardwood chips, corn stover, and jack pine ch1ps. Two types of bench-scale experiments were conducted:

1. Devolatilization experiments in a laminar-flow reactor

2. Isothermal char gasification experiments in a thermobalance using a mixture of hydrogen, steam, and hellum. 


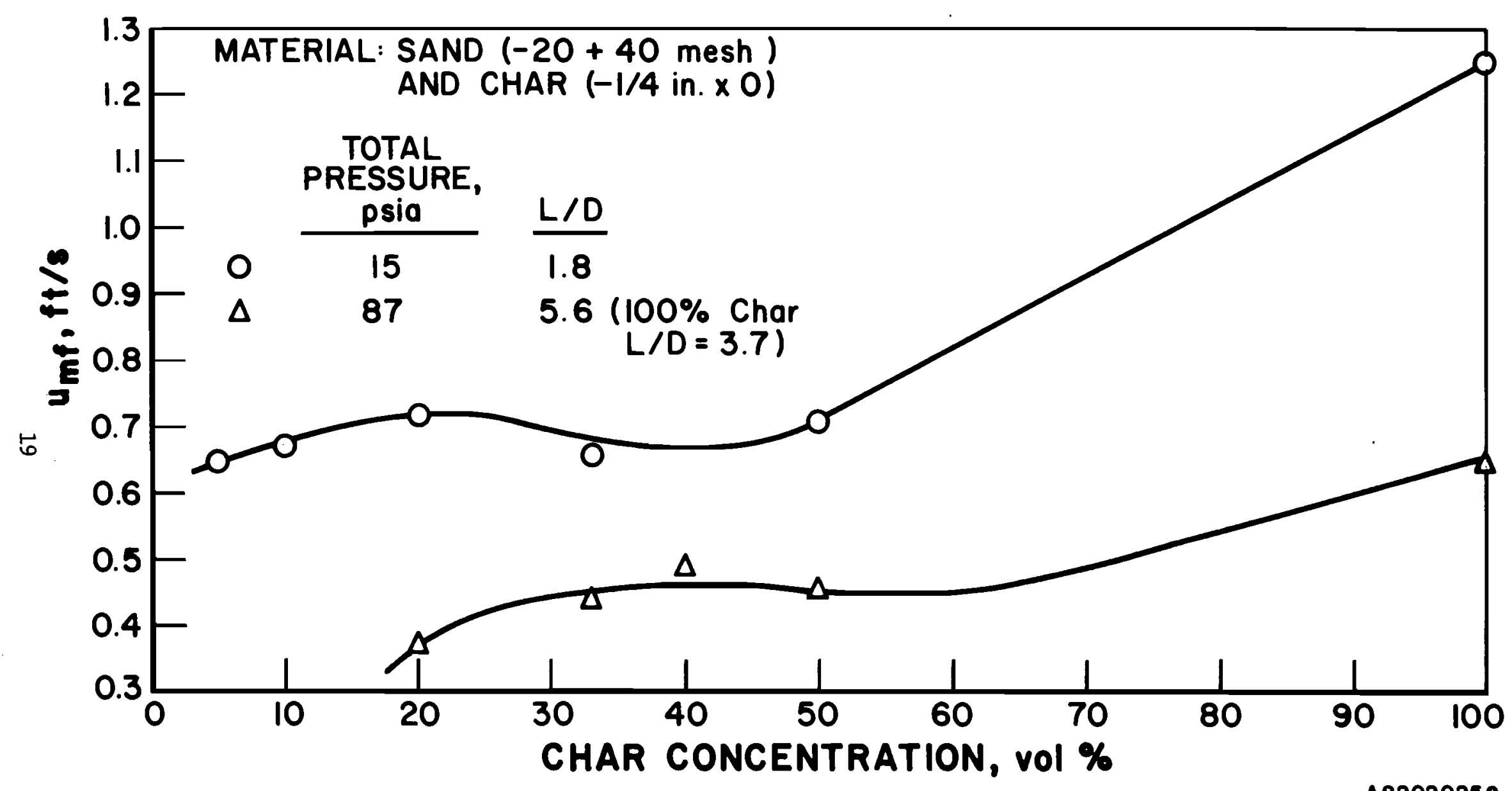

Figure 6. MINIMUM FLUIDIZATION VELOCITY AS A FUNCTION OF CHAR CONCENTRATION AT TWO PRESSURES 


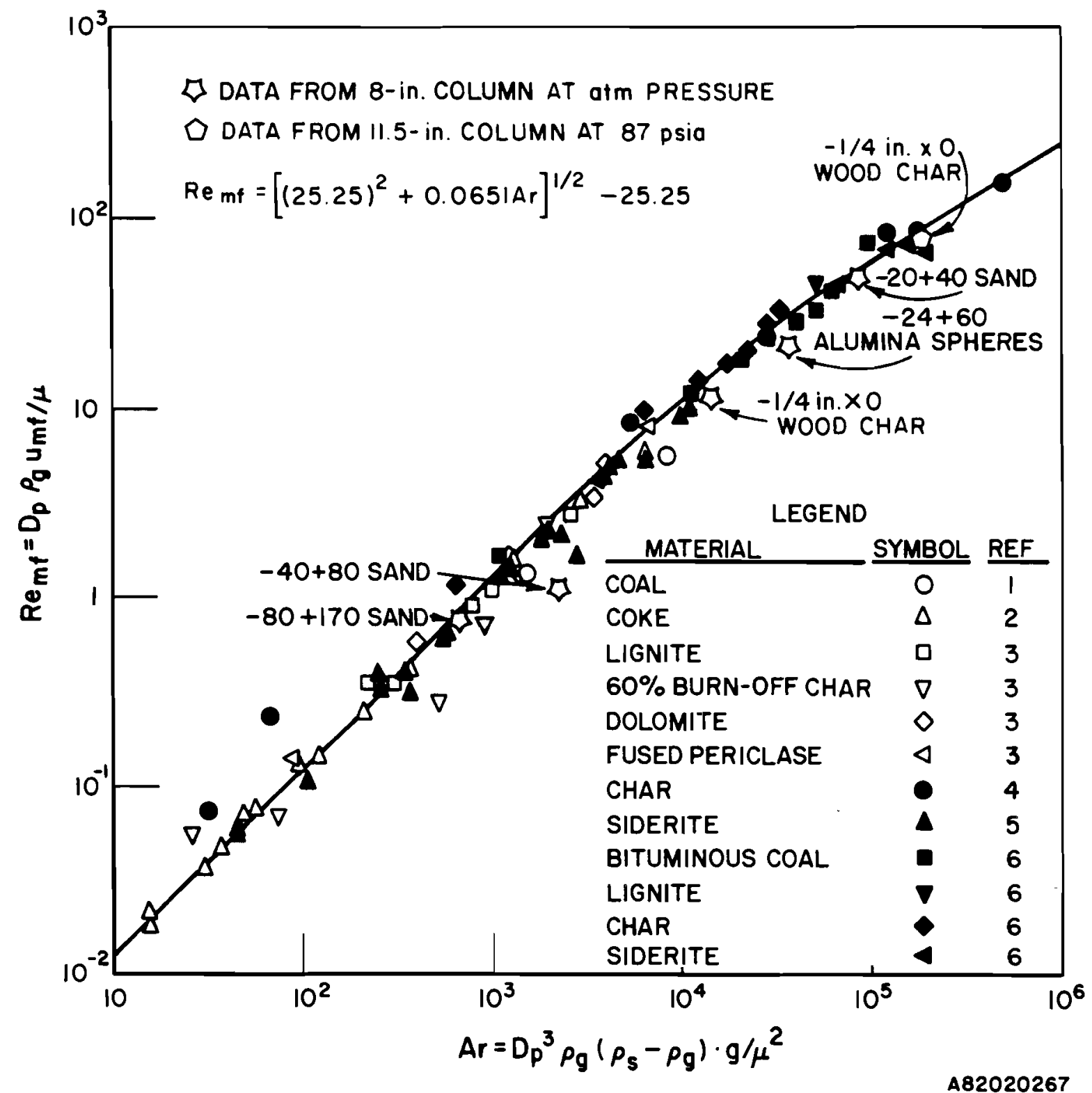

F1gure 7. CORRELATION FOR THE PREDICTION OF MINIMUM FLUIDIZATION VELOCITY (Data Points Defined in Reference 3) 
The rapid devolatilization experiments produced data on the effect of process variables on product yields and compositions. The 1sothermal char gasification experiments contributed kinetic data on the slower, ratecontrolling steam-char reactions in gaseous atmospheres containing the typical percentages of hydrogen and steam that would be expected in an adiabatic gasifier.

Laminar-Flow Devolatilization Experiments

The rapid devolatilization characteristics of maple hardwood were investigated in a laminar-flow reactor. The apparatus was devised to provide a range of devolatilization temperatures at short residence times. Figure 8 shows a simplified schematic diagram of the laminar-flow reaction system. The system 1s composed of three distinct sections: 1) feed system, 2) reactor system, and 3) product collection systems.

The feed system was designed to supply the gaseous medium at the temperature, pressure, and flow rate selected for each experiment and to introduce the sized blomass into the reactor. The gas was preheated to the selected temperature and fed to the reactor system at different volumetric flow rates so that the linear velocity of the gas in the reactor was constant for all experiments. The biomass was stored in a high-pressure feed hopper. Its feed rate could be adjusted from 0.1 to 1 gram per minute by changing the rotational speed of the screw feeder located at the bottom of the hopper. The biomass particles flowed through a water-cooled injection probe into the hot reactor zone.

The main section of the reactor system was an 8-foot-long, 2-inch-ID stainless-steel core, which was surrounded by seven electrical heaters. The f1rst two heaters were used to maintain and/or preheat the feed gas to the reaction temperature. The last five heaters were used to maintain the reactor temperature. A balanced-pressure reactor design was employed to facilitate temperature control, reduce heat-up time, and minimize the power required. The 2-1nch-ID reactor core was a thin-walled (1/4-1nch-thick) cylindrical reactor that did not see any large differential pressures. The reactor core was placed Inside a 12-1nch pipe as a pressure vesse1; the pressure between the reactor and the enclosing shell was adjusted, using nitrogen, to match the pressure inside the reactor core. This reactor system was capable of operating at temperatures up to $1600^{\circ} \mathrm{F}$ and pressures up to $1500 \mathrm{psig}$. Inside 


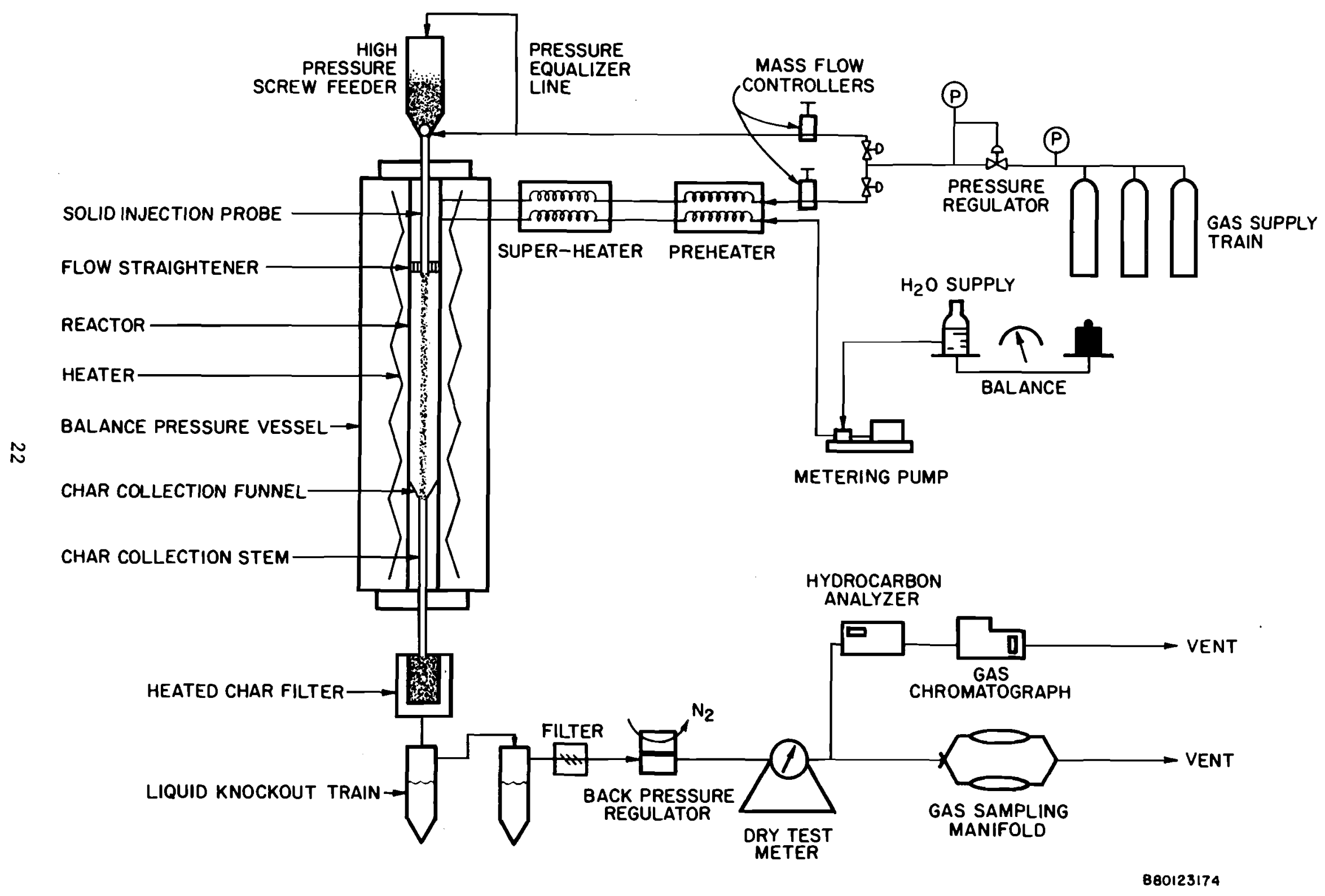

FIgure 8. SCHEMATIC FLOW DIAGRAM OF THE LAMINAR-FLOW REACTOR SYSTEM 
the reactor core was an adjustable char collection probe. The purpose of this probe was to transmit the char and gas with little or no further reaction to the char filter located at the bottom of the reactor. To quench the reaction, the probe was cooled to below $800^{\circ} \mathrm{F}$, elther with water or a1r. The probe length was adjustable so that the free-fall distance of the char particles could be varied from 12 to 48 inches, which varies the contact or residence time.

The gas and char stream passed through the collection probe and into a heated filter, where the char was separated from the gas stream. The porous sintered-metal type filter retalned particles greater than 5 micrometers. It was kept at about $450^{\circ} \mathrm{F}$ to prevent liquid products from condensing in $1 \mathrm{t}$. The solids-free gas.stream was then passed through a series of cold liquidknockout pots and a filter medium, where o1ls, tars, water, and heavy hydrocarbons were collected. The pressure of the gas stream was then reduced to atmospher1c pressure and metered through a dry-test meter. The gas stream then flowed through a sample mantfold, where gas samples were collected intermittently for mass spectroscopy analysis.

At the beginning of each experiment, the feed hopper was charged with 70 to 100 grams of prepared feed ( 1 zized to $-60+80$ mesh). After the system was brought to operating pressure and checked for leaks, the heaters were energized to heat the reactor and then to maintaln 1sothermal temperatures. During the start-up, collection bombs were placed in the sample manifold, and the devolatilization gas flow rate was set. Once the system was at operating pressure and temperature, the gas flow rate was rechecked and the experiment was inftiated by starting the feeder.

Usually within 5 minutes of feeding, the Infrared analyzer (IRA) began showing a trace of $\mathrm{CO}$ and $\mathrm{CO}_{2}$; at about 15 minutes, steady-state operation was obtained. The steady-state period was determined when the composition of the product gases monftored by the IRA remained constant. The experiment was continued at steady-state operation, generally for more than 4 hours, with gas samples taken perfodically. Improved materlal balances were obtalned with longer runs, which reduced the errors of feed rate 1rregularities and the collection of small quantities of products. To end the experiment, the solids feed was stopped, the gas flow reduced, and the unit depressurized after the reactor cooled. 


\section{Experimental Bench-Scale Test Results}

The results of the laminar-flow devolatilization experiments presented here derive from a planned, parametric study of the devolatilization behavior of maple hardwood. The rapid devolatilization behavior was investigated as a function of temperature, pressure, devolatilization gas medium, feed molsture variation, and residence time.

The temperature of the reaction zone was varied from $1000^{\circ}$ to $1600^{\circ} \mathrm{F}$ at a total pressure of $300 \mathrm{psig.} \mathrm{A} \mathrm{few} \mathrm{tests} \mathrm{were} \mathrm{made} \mathrm{at} 100$ and 200 psig. Tests with an inert helium devolatilization atmosphere simulated devolatilization pyrolysis, and a gas with a concentration of $5 \%$ hydrogen in helium was selected to simulate devolatilization in a conceptual steam-oxygen gasification process.

Table 7 lists the data from all the experiments. Elemental and overall material balances are given in Table 8. Figure 9 presents the effect of the devolatilization temperature on the yields of gas, liquids, and char for one estimated residence time in the laminar-flow reaction zone of approximately 2 seconds. Results are shown for both the hellum and the 5\% hydrogen gas mediums.

It is difficult to determine the residence time exactly of the biomass particles in the controlled temperature zone of the laminar-flow apparatus, because the particles undergo a shape change and a weight 1 oss of about $80 \%$ or more. Under these experimental conditions, particle heat-up was assumed to be principally through radiative heat transfer, which produces relatively high heating rates. Consequently, the particles would reach the reaction temperature in much less than 1 second. Particle size, density, shape, gas density, and viscosity all are factors that affect the free-fall veloctty of the particles. These factors could change dramatically as the particles devolatilize. Nevertheless, an estimate of the residence times of the solid particles was made by measuring the free-fall velocity of sized $(-60+80$ mesh) maple hardwood chips at ambient, nonreactive conditions. On this basis, the approximate residence times were $1.2,2.0$, and 3.2 seconds, respectively, for the 18-, 30-, and 48-inch reaction zones in the apparatus. 
Table 7. SUMMARY OF LAMINAR-FLOW DEVOLATILIZATION DATA

Run No.

Temperature, ${ }^{\circ} \mathrm{F}$ Pressure, psig Gas Medium Run time, mit

Amount Fed, $8($ ary

Reactor Length, in

Devolatilization Yields,

wt $z$ of dry feed

Liquids

char

Gas Composition, vol $z$

$\mathrm{CO}^{2}$
$\mathrm{CO}_{2}$
$\mathrm{H}_{2}$
$\mathrm{CH}_{4}$
$\mathrm{C}_{2} \mathrm{H}_{6}$
$\mathrm{C}_{2} \mathrm{H}_{4}$
$\mathrm{C}_{3} \mathrm{H}_{8}$
$\mathrm{C}_{3} \mathrm{H}_{6}$
$\mathrm{C}_{3} \mathrm{H}_{6} \mathrm{O}$
$\mathrm{C}_{6} \mathrm{H}_{6}$

MHC 17 MHC 18 MHC 31 MHC 33 MHC 19 MHC 20A MHC 21 MHC 25 MHC 25A HAC 28 MHC 22 MHC 22A MHC 26A MHC 29 MHC 32

\begin{tabular}{|c|c|c|c|c|c|c|c|c|c|c|c|c|c|c|c|c|c|c|c|c|c|c|c|}
\hline 1300 & 1300 & 1300 & 1500 & 1600 & 1000 & 1000 & 1000 & 1000 & 1300 & 1300 & 1300 & 1300 & 1300 & 1500 & 1500 & 1500 & 1500 & 1500 & 1500 & 1600 & 1600 & 1600 & 1600 \\
\hline 300 & 300 & 300 & 300 & 300 & 300 & 300 & 300 & 300 & 300 & 300 & 300 & 300 & 300 & 300 & 300 & 300 & 300 & 300 & 300 & 300 & 100 & 200 & 300 \\
\hline He & He & $\mathrm{He}$ & $\mathrm{He}$ & $\mathrm{He}$ & $\mathrm{H}_{2} / \mathrm{He}^{*}$ & $\mathrm{H}_{2} / \mathrm{He}$ & $\mathrm{H}_{2} / \mathrm{He}$ & $\mathrm{H}_{2} / \mathrm{He}$ & $\mathrm{H}_{2} / \mathrm{He}$ & $\mathrm{H}_{2} / \mathrm{He}$ & $\mathrm{H}_{2} / \mathrm{He}$ & $\mathrm{H}_{2} / \mathrm{He}$ & $\mathrm{H}_{2} / \mathrm{He}$ & $\mathrm{H}_{2} / \mathrm{He}$ & $\mathrm{H}_{2} / \mathrm{He}$ & $\mathrm{H}_{2} / \mathrm{He}$ & $\mathrm{H}_{2} / \mathrm{He}$ & $\mathrm{H}_{2} / \mathrm{He}$ & $\mathrm{H}_{2} / \mathrm{He}$ & $\mathrm{H}_{2} / \mathrm{He}$ & $\mathrm{H}_{2} / \mathrm{He}$ & $\mathrm{H}_{2} / \mathrm{He}$ & $\mathrm{H}_{2} / \mathrm{He}$ \\
\hline 300 & 292 & 210 & 300 & 70 & 152 & 194 & 180 & 266 & 333 & 299 & 240 & 270 & 250 & 284 & 270 & 184 & 134 & 50 & 98 & 360 & 300 & 300 & 210 \\
\hline 5.44 & 7.80 & 61 & .55 & 1.02 & 17.81 & 27.28 & 32.12 & 30.73 & 55.25 & 59.92 & 52.53 & 38.21 & 40.81 & 47.87 & 53.64 & 23.91 & 15.01 & 2.14 & 9.53 & 78.13 & 47.29 & 57.01 & 28.06 \\
\hline 3.1 & 3.1 & 3.1 & 3.1 & 3.1 & 3. & 3.1 & 3.1 & 3.1 & 3.1 & 3.1 & 3.1 & 3.1 & 3.1 & 3.1 & 3.1 & 3.1 & $12.1^{\star \star}$ & $25.9^{\star \star}$ & $12.6^{\star \star}$ & 3.1 & 3.1 & 3.1 & 3.1 \\
\hline & 30 & 30 & & & n & 18 & & & 30 & & & & & & & & & & 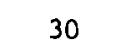 & & 30 & & \\
\hline
\end{tabular}

$\begin{array}{lllllllllllllllllllllllll}45.8 & 68.3 & 66.8 & 70.5 & 72.5 & 72.2 & 48.4 & 48.3 & 47.2 & 60.2 & 65.7 & 64.8 & 58.8 & 75.4 & 72.2 & 79.7 & 73.3 & 84.6 & 83.3 & 90.4 & 80.6 & 80.7 & 85.8 & 84.9 & 79.6\end{array}$ $\begin{array}{llllllllllllllllllllllllllll}25.0 & 11.4 & 11.6 & 14.2 & 8.0 & 5.4 & 33.9 & 26.3 & 24.6 & 18.0 & 15.1 & 14.2 & 12.1 & 12.9 & 15.0 & 9.1 & 8.5 & 6.7 & 4.9 & 13.7 & 8.6 & 6.3 & 11.4 & 6.6 & 6.6\end{array}$ $\begin{array}{llllllllllllllllllllllllll}12.4 & 10.3 & 7.9 & 9.7 & 9.0 & 6.6 & 13.6 & 14.5 & 12.8 & 16.0 & 4.7 & 4.8 & 5.6 & 9.7 & 6.3 & 3.5 & 7.4 & 9.2 & 6.6 & 7.7 & 9.5 t & 6.5 & 5.4 & 5.1 & 6.4 t\end{array}$

$\star 5 z \mathrm{H}_{2}, 95 \% \mathrm{He}$.

Feed moisture content may affect devolactlizat ton results.

$\uparrow$ Corrected by ash balance.

$171 / 65058 \mathrm{fr}-\mathrm{t} / \mathrm{RPP}$

\begin{tabular}{|c|c|c|c|c|c|c|c|c|c|c|c|}
\hline 50 & 48 & 50 & 47 & 44 & 45 & 58 & 55 & 54 & 55 & 54 & 56 \\
\hline 15 & 10 & 9 & 11 & 10 & 11 & 14 & 18 & 20 & 16 & 8 & 9 \\
\hline 12 & 16 & 16 & 17 & 23 & 24 & - & -- & -- & -- & - & -- \\
\hline 14.0 & 19.3 & 18.7 & 19.7 & 19.2 & 19.3 & 17.8 & 17.8 & 17.9 & 21.6 & 27.1 & 25.0 \\
\hline 2.6 & 1.5 & 1.6 & 1.2 & 0.3 & - & 4.1 & 2.8 & 3.3 & 4.3 & 7.9 & 7.6 \\
\hline 3.5 & 3.7 & 3.5 & 3.5 & 1.6 & - & 4.1 & 1.9 & 1.6 & 0.9 & 1.4 & 1.4 \\
\hline 1.8 & - & -- & -- & -- & -- & 1.4 & 0.9 & 0.8 & 0.9 & -- & -- \\
\hline-- & -- & -- & -- & -- & -- & -- & 1.9 & 0.8 & 0.9 & -- & -- \\
\hline 0.9 & - & -- & -- & -- & -- & 1.4 & 1.9 & 1.6 & - & -- & -- \\
\hline-- & 0.7 & 1.2 & 0.8 & 1.6 & 0.7 & -- & - & -- & 0.9 & 0.9 & 1.0 \\
\hline
\end{tabular}

$\begin{array}{ccccc}55 & 54 & 54 & 51 & 51 \\ 10 & 9 & 9 & 8 & 9 \\ -- & -- & -- & -- & -- \\ 24.7 & 25.5 & 26.1 & 37.8 & 35.2 \\ 7.5 & 8.7 & 7.5 & 0.7 & 2.1 \\ 2.1 & 1.4 & 1.7 & 0.7 & 1.2 \\ -- & -- & - & -- & - \\ -- & -- & -- & -- & - \\ -- & -- & -- & -- & - \\ 0.8 & 1.4 & 1.7 & 1.7 & 1 .\end{array}$

$\begin{array}{cccccccc}52 & 51 & 49 & 48 & 57 & 58 & 58 & 53 \\ 7 & 10 & 8 & 10 & 9 & 8 & 7 & 7 \\ -- & - & -- & -- & -- & -- & -- & - \\ 38.8 & 35.4 & 37.7 & 38.6 & 32.5 & 32.2 & 33.7 & 37.6 \\ 0.4 & 1.5 & 2.4 & 1.3 & - & 0.1 & 0.4 & 0.3 \\ -- & 1.0 & 1.2 & 1.3 & -- & 0.3 & 0.4 & 0.3 \\ -- & - & -- & -- & -- & -- & - & - \\ -- & -- & -- & -- & -- & -- & -- & -- \\ -- & - & -- & -- & -- & -- & -- & - \\ 1.8 & 1.6 & 1.2 & 1.3 & 1.4 & 1.7 & 1.1 & 1.9\end{array}$


Table 8. Material baLANCES FOR LAMINAR-FLOW DEVOLATILIZATION DATA

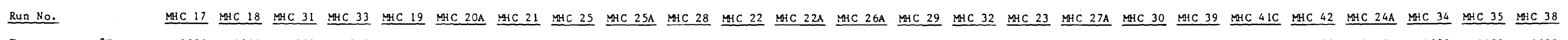

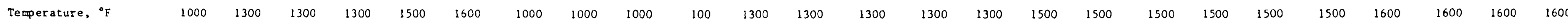

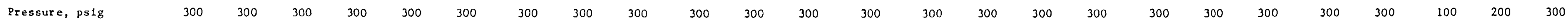

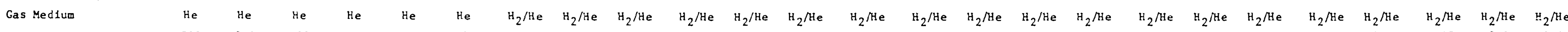
Run Time, min Amount Fed, $g$ (dry) Feed Molsture, $z$ $\begin{array}{cccccc}200 & 300 & 292 & 210 & 300 & 270 \\ 30.95 & 56.44 & 47.80 & 35.61 & 51.55 & 51.02\end{array}$ Reactor length, in $\begin{array}{llllll}152 & 194 & 180 & 266 & 333 & 299\end{array}$ Balances, $z$

$\begin{array}{lllllll}\text { Carbon } & 73 & 84 & 80 & 86 & 85 & 76 \\ \text { Hydrogen } & 86 & 90 & 86 & 96 & 91 & 83 \\ \text { Oxygen } & 92 & 95 & 93 & 103 & 94 & 100 \\ \text { ral1 }^{*} & 83 & 90 & 86 & 94 & 90 & 84 \\ \text { version }^{\text {** }} & 85 & 89 & 91 & 90 & 90 & 92\end{array}$

Conversion ${ }^{\star *}$

id, char collected.

* Conversion $=($ gas +11 quid $) /($ gas +1 1quid + char $)(z)$

$171 / 65058 \mathrm{f}-\mathrm{t} / \mathrm{RPP}$ 


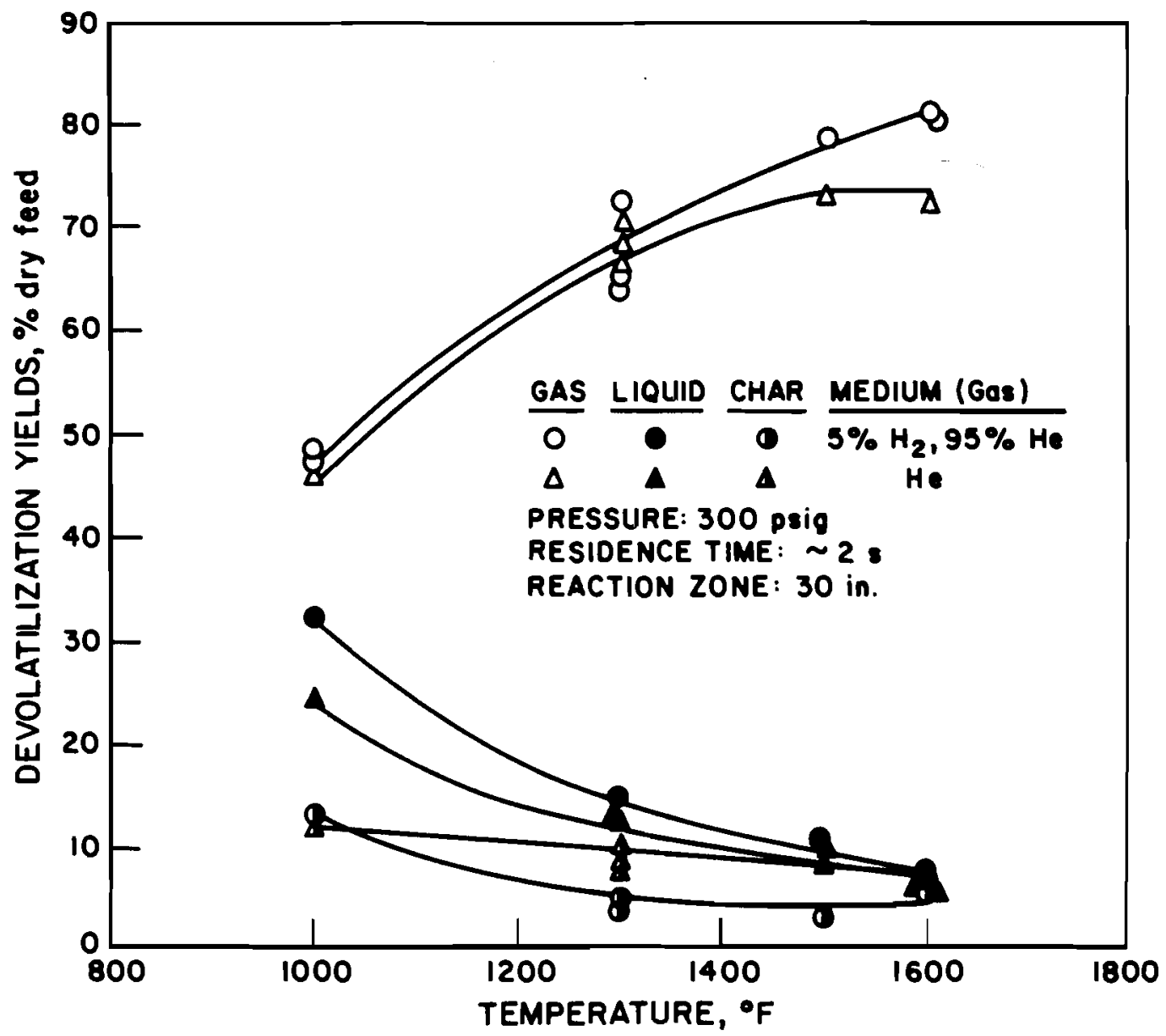

$\triangle 82020323$

Figure 9. DEVOLATILIZATION YIELDS AS A FUNCTION OF TEMPERATURE IN $5 \% \mathrm{H}_{2}, 95 \% \mathrm{He}$, AND IN $100 \%$ HELIUM 
Figure 10 depicts the yields for the three residence times or reaction zone lengths as a function of temperature. As expected, the gas production shows a consistent increase as the reaction time and temperature increase. The Increased gas ylelds obtalned as the solids residence time is increased could result not only directly from higher conversions, but also possibly through secondary liquid decomposition reactions or even steam-char reactions at the higher temperatures.

The effect of the length of residence time upon the char and liquid yields is not as clear as with the gas yields. Secondary reactions such as thermal cracking of the heavier hydrocarbons may be occurring to cause the observed slight increase, rather than a decrease, in the char yields for the longest residence-time run, assuming that no measurement or collection error is present. If secondary reaction effects are contributing to the char values, then more definitive experiments are required to uncover these effects. These results show definite trends for temperature and residencetime dependence that are useful for process design in general and analysis of the PRU test results.

Figure 11 shows the effect of the temperature and residence time on the ratio of $\mathrm{CO}, \mathrm{CH}_{4}$, and $\mathrm{CO}_{2}$ gas products to feed carbon. There is a small change in the production of $\mathrm{CO}_{2}$ relative to the feed carbon as both residence time and temperature are Increased; however, larger effects on both $\mathrm{CO}$ and $\mathrm{CH}_{4}$ production are observed. It is the increased production of $\mathrm{CO}$ and $\mathrm{CH}_{4}$ that is primarily responsible for the increased overall gas production shown in Figures 9 and 10. Combined, they account for $75 \%$ to $90 \%$ of the product gases.

Note that a lower value of methane was measured at $1600^{\circ} \mathrm{F}$ than at $1500^{\circ} \mathrm{F}$. Th1s was confirmed with a duplicate experimental run. Other investigators ${ }^{4-6}$ have reported that methane content diminishes as temperatures approach $1800^{\circ} \mathrm{F}$ and beyond. Such conditions would favor the production of a synthesis gas for methanol conversion. The laminar-flow bench-scale apparatus was limited to controlled temperatures of $1600^{\circ} \mathrm{F}$ in the reaction zone. The PRU, however, was designed for operating temperatures up to $1800^{\circ} \mathrm{F}$.

Figure 12 shows an increase of the conversion of blomass to gases and liquids with temperature for the three residence times. The conversion fraction is defined as the ratio of the gas plus liquid products to the sum of gas, liquid, and char products on a weight fraction basis. A relationship may 


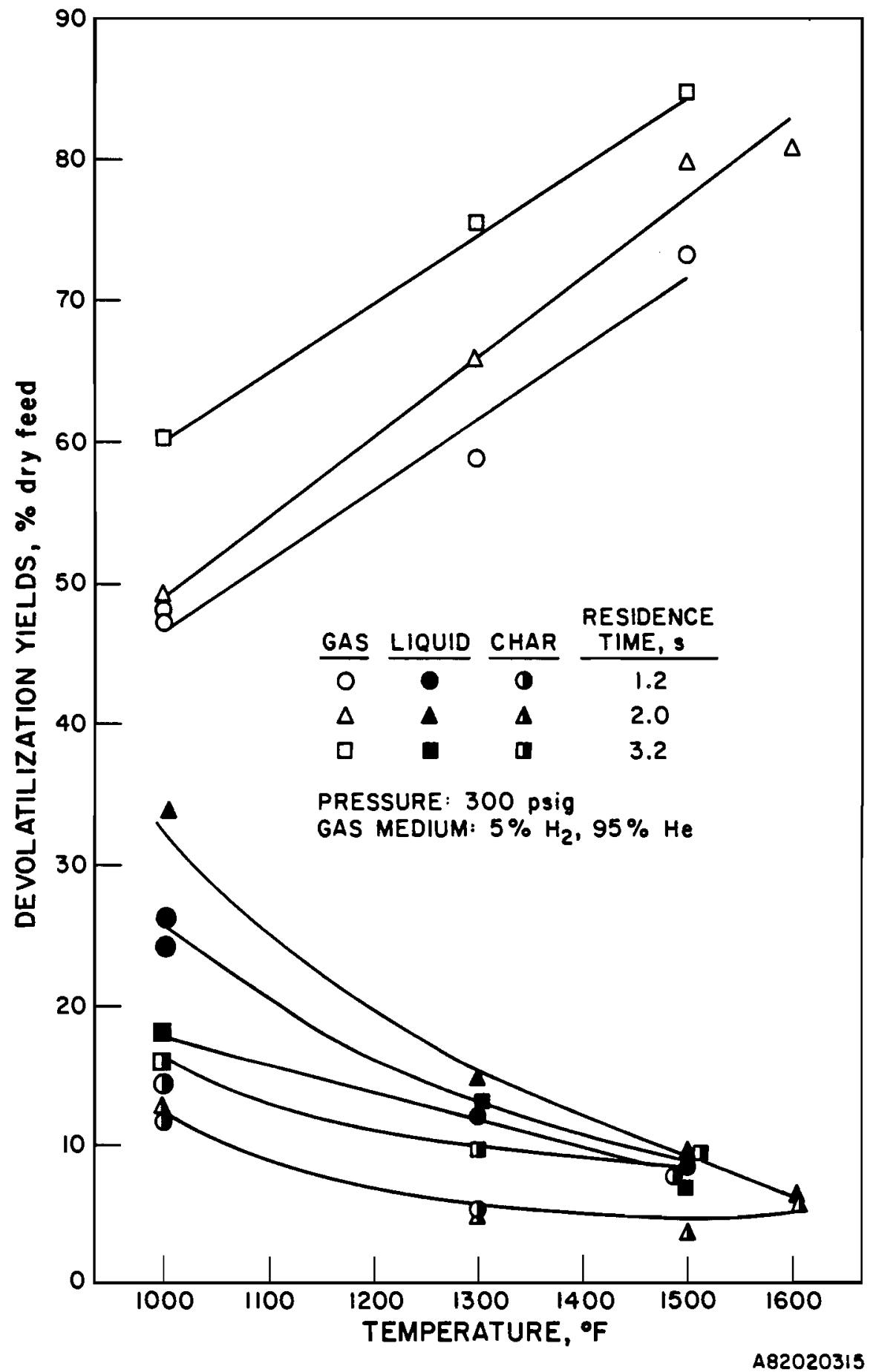

Figure 10. DEVOLATILIZATION YIELDS AS A FUNCTION OF TEMPERATURE FOR VARIOUS RESIDENCE TIMES 


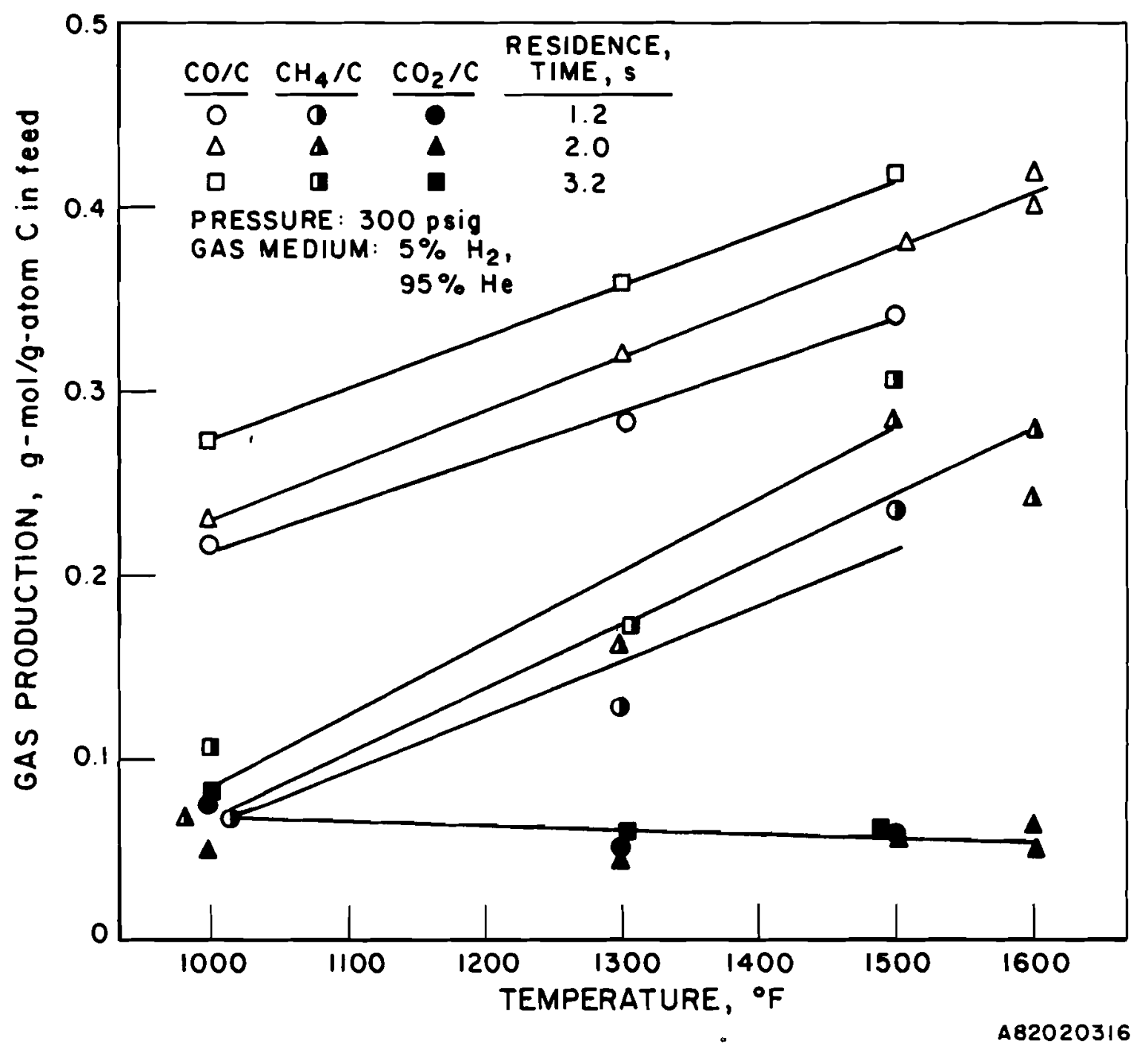

Figure 11. GAS SPECIE PRODUCTION AS A FUNCTION OF TEMPERATURE FOR VARIOUS RESIDENCE TIMES AT 300 psig 


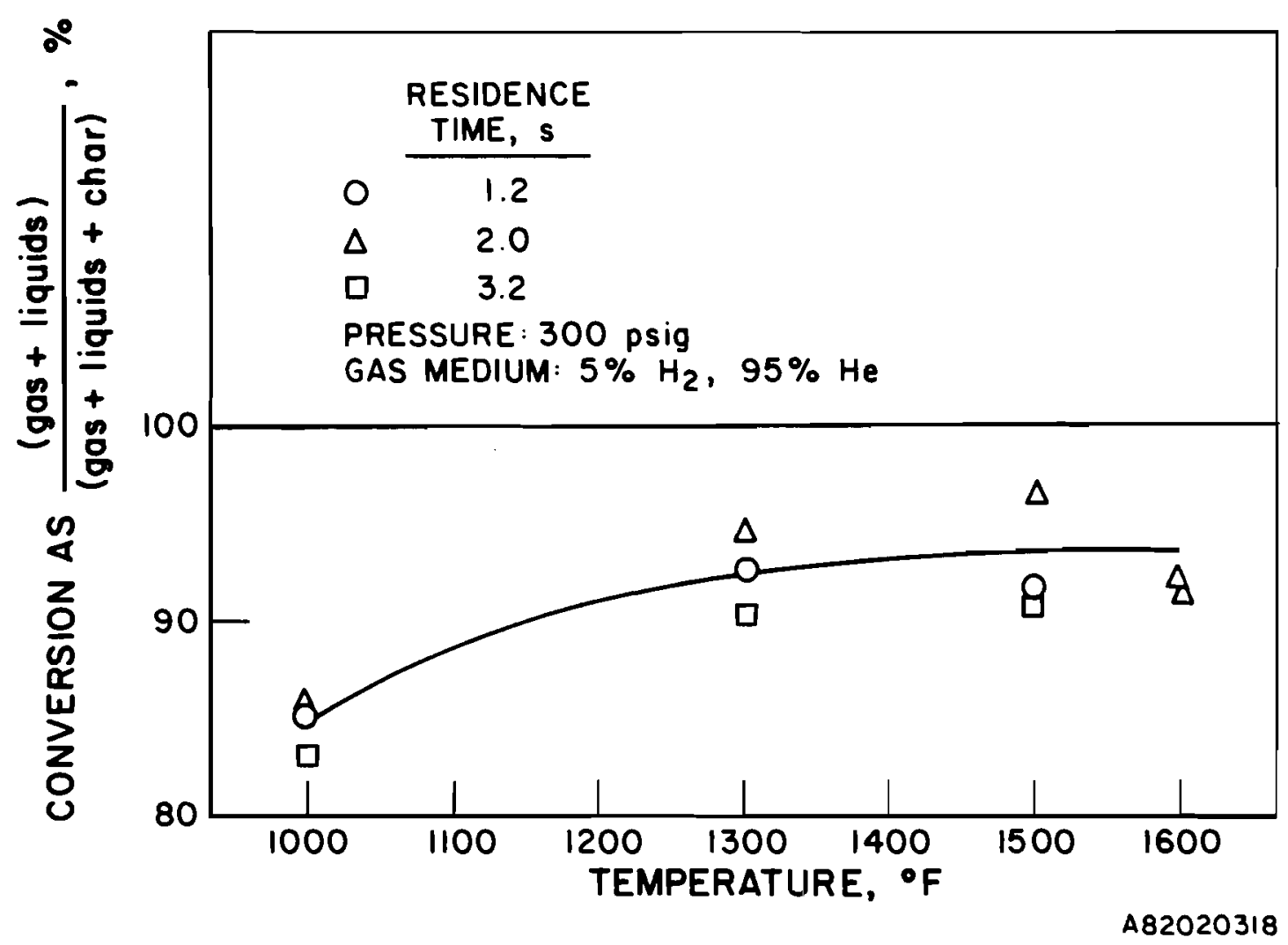

Figure 12. CONVERSION VERSUS TEMPERATURE 
exist between the conversion and residence time, as shown in Figure 12; however, the variation is within the experimental uncertainties.

Figure 13 plots the conversion against the reaction zone length, which is a more precise value than the estimate of residence time. For temperatures of $1300^{\circ}$ to $1600^{\circ} \mathrm{F}$, a slight difference in conversion is shown; however, these differences are still within the experimental uncertainties. The decrease for the longest residence time could be due, perhaps, to the formation of char from a portion of the liquids. More definitive experiments would be necessary to confirm that.

Three runs were made to explore the effect of total pressure on devolatilization. These runs were made at $1600^{\circ} \mathrm{F}$ and 100,200 , and $300 \mathrm{ps} 1 \mathrm{~g}$ with the approximate 2-second residence time. The pressure did not affect the conversion level or overall gas composition significantly. The most significant differences observed were that about $5 \%$ less gas, but $45 \% 1$ ess 11quids, was measured at 300 psig than at 100 psig.

Three different feed molsture experimental runs were conducted to Investigate the effect of feed molsture content upon the ylelds and conversions. The molsture content was varied from 3 to 12 to 27 weight percent, approximately, for run conditions of $1500^{\circ} \mathrm{F}, 300 \mathrm{psig}$, and a 2-second residence time.

The duration of the experiments with the 12 and 27 weight percent molsture content values was shorter than for most previous experiments because steady feeding was difficult with the molst $-60+80$ mesh material. The feeder would feed steadily for only about one-half of the previous run times. Hence, shorter run times were made. As these have greater experimental error, duplicate runs at each condition were planned. Consequently, feeding problems were recurrent with the higher moisture material in the small-diameter screw feeder currently in the laminar-flow apparatus. Very little difference could be discerned among the various runs to attribute to feed molsture variation. A modified experimental procedure or apparatus would be necessary to isolate the effect of feed molsture content.

Isothermal Char Gasification Experiments

The gasification of the blomass char, obtalned from devolatilization, is the slowest step in the overall conversion process for the production of 

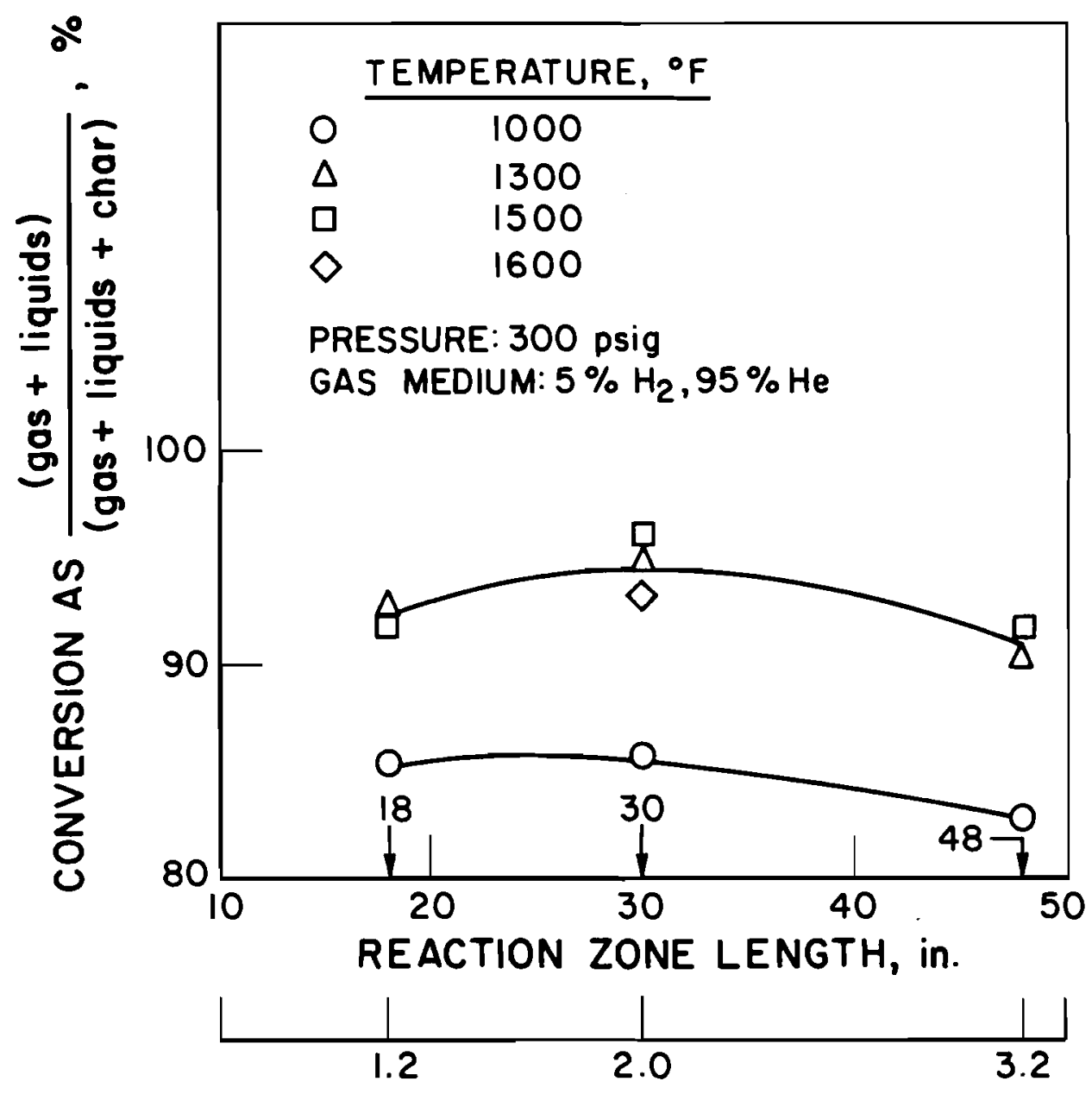

ESTIMATED RESIDENCE TIMES, $s$

A82020319

Figure 13. CONVERSION AS A FUNCTION OF REACTION ZONE LENGTH FOR VARIOUS TEMPERATURES AT 300 psIg 
medium-Btu gas from biomass. To obtain a measure of the rate of gasification of the char under the proposed reaction conditions (temperature, pressure, and gas composition), a series of prepared chars were gasified at a total pressure of $300 \mathrm{psig}$ over a temperature range of $1350^{\circ}$ to $1700^{\circ} \mathrm{F}$ in a gas medium consisting of about $50 \% \mathrm{H}_{2} \mathrm{O}, 5 \% \mathrm{H}_{2}$, and $45 \%$ inert gas (He). As mentioned previously, the selection of these main experimental conditions of temperature and pressure was based on the designed PRU operating conditions. Experiments at different total pressures and different gas mediums were also conducted.

All of the char gasification rate experiments were conducted in a thermobalance reactor. This apparatus is capable of continuously monftoring the weight of a sample reacting under simulated process conditions. Figure 14 is a schematic diagram for the thermobalance reactor system. In a typical experiment a representative sample of 1 to 2 grams of the char is suspended in a wire mesh screen basket from a transducer and brought in contact with the gasification medium at predetermined reaction conditions. In this bench-scale experimentation task, two series of char gasiflcation experiments were made with maple hardwood, jack, pine softwood, and corn stover. Essentially, the chars were prepared in two different methods.

The chars in the first serfes of experiments were obtained by devolatilization in nitrogen ( $1 \mathrm{~atm}$ ) in the temperature range of $1350^{\circ}$ to $1700^{\circ} \mathrm{F}$. These were reported previously. ${ }^{2}$ The rate of heating was $\sim 20^{\circ} \mathrm{F} / \mathrm{min}$, and the chars were kept at the maximum temperature for 30 minutes. The reactivity of the chars produced under these slow heating conditions is recognized to differ from that of chars produced in-situ, that 1s, at high heat-up rates in the gasification reactor. Experience with other carbonaceous materials indicates that the chars obtalned under slow heating conditions have a lower reactivity than chars obtained under high heating rates where only a very short time is allowed for char stabllization. The justification of using the laboratoryproduced or stabilized chars in the Inttial experimentation, however, is that their mode of generation is well defined. As their reactivity could be lower than that of the chars produced in-situ, using their reactivity data to estimate the residence time in the PRU reactor would yield a conservative value for the residence time.

A subsequent serles of experiments were conducted with in-situ chars produced directly inside the thermobalance reactor. A procedure was devised 


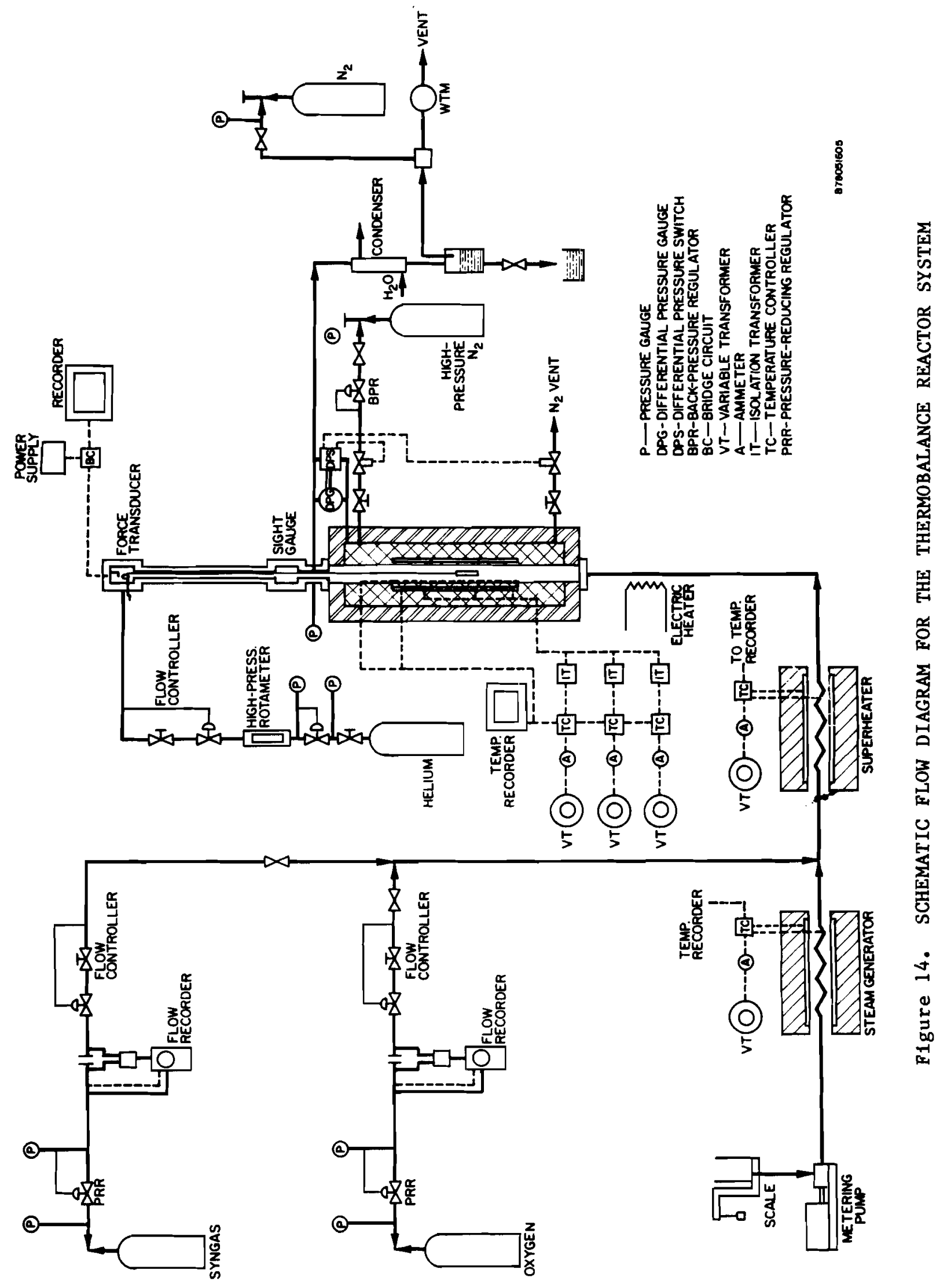


to run the raw biomass materials in the thermobalance reactor and to separate the change in weight due to devolatilization from the change due to char carbon gasification.

The raw blomass ( $1 \mathrm{gram})$ was placed in a wire mesh basket and put into the cooler, near room temperature, upper chamber region of the thermobalance reactor. The preselected temperature, pressure, and gas medium were established in the lower region; then the basket was quickly lowered into it and the weight change continuously monitored. The principal mode of heating is radiation; hence, the heat-up rate was expected to be quite high. In this method, the char produced in-situ reacted immediately upon devolatilization.

A parametric study of the rate of gasification of the in-situ chars of the three representative biomass materials simllar to that for the stabilized chars was completed in this program. The corn stover char behavior, as with the stabilized chars, was different from that of chars of maple or jack pine.

Maple Hardwood and Jack Pine Results

Gasification of the in-situ chars of maple and jack pine was conducted in three steam-hydrogen mixtures: 1) $5 \% \mathrm{H}_{2}+45 \% \mathrm{He}+50 \% \mathrm{H}_{2} \mathrm{O}$, 2) $10 \% \mathrm{H}_{2}+40 \%$ $\mathrm{He}+50 \% \mathrm{H}_{2} \mathrm{O}$, and 3) $25 \% \mathrm{H}_{2}+25 \% \mathrm{He}+50 \% \mathrm{H}_{2} \mathrm{O}$.

The experimental results showing the char weight-loss fraction (dry ashfree basis) with reaction time at various temperatures are shown in Figures 15 through 17 for maple hardwood and in Figures 18 through 20 for jack pine. In addition, using the first steam-hydrogen mixture, the effect of pressure on the rate of gasification was studied with maple hardwood and is also shown in Figure 15. Two effects may be present to produce the behavior shown by the 10-psig data. One is that the rate or slope at $10 \mathrm{psig}$ is lower because of the strong dependence of the rate on the partial pressure of steam; the pressures of 100 and 300 psig significantly increase the rate. The second effect is that the initial amount of devolatilization or initial weight loss producing the in-situ char is greater at lower pressures.

The experimental results of gasification of maple hardwood and jack pine chars were analyzed and described with the first order rate expression -

or

$$
\frac{d x_{c}}{d t}=k\left(1-x_{c}\right)
$$

$$
-\ln \left(1-x_{c}\right)=k t
$$




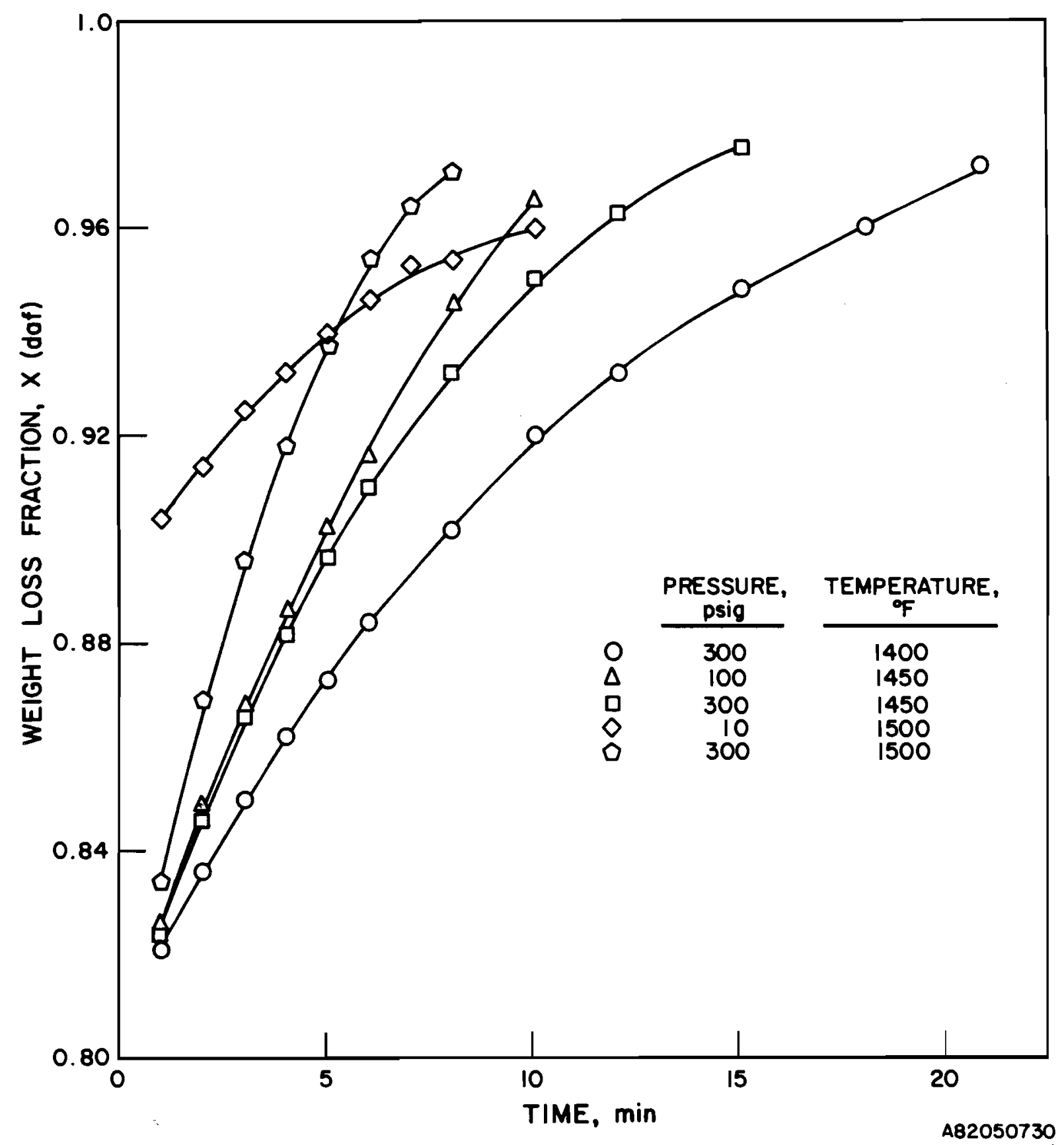

F1gure 15. GASIFICATION OF IN-SITU CHAR FROM MAPLE HARDWOOD $(-12+16$ Mesh $)$ IN $5 \% \mathrm{H}_{2}+45 \% \mathrm{He}+50 \% \mathrm{H}_{2} \mathrm{O}$ 


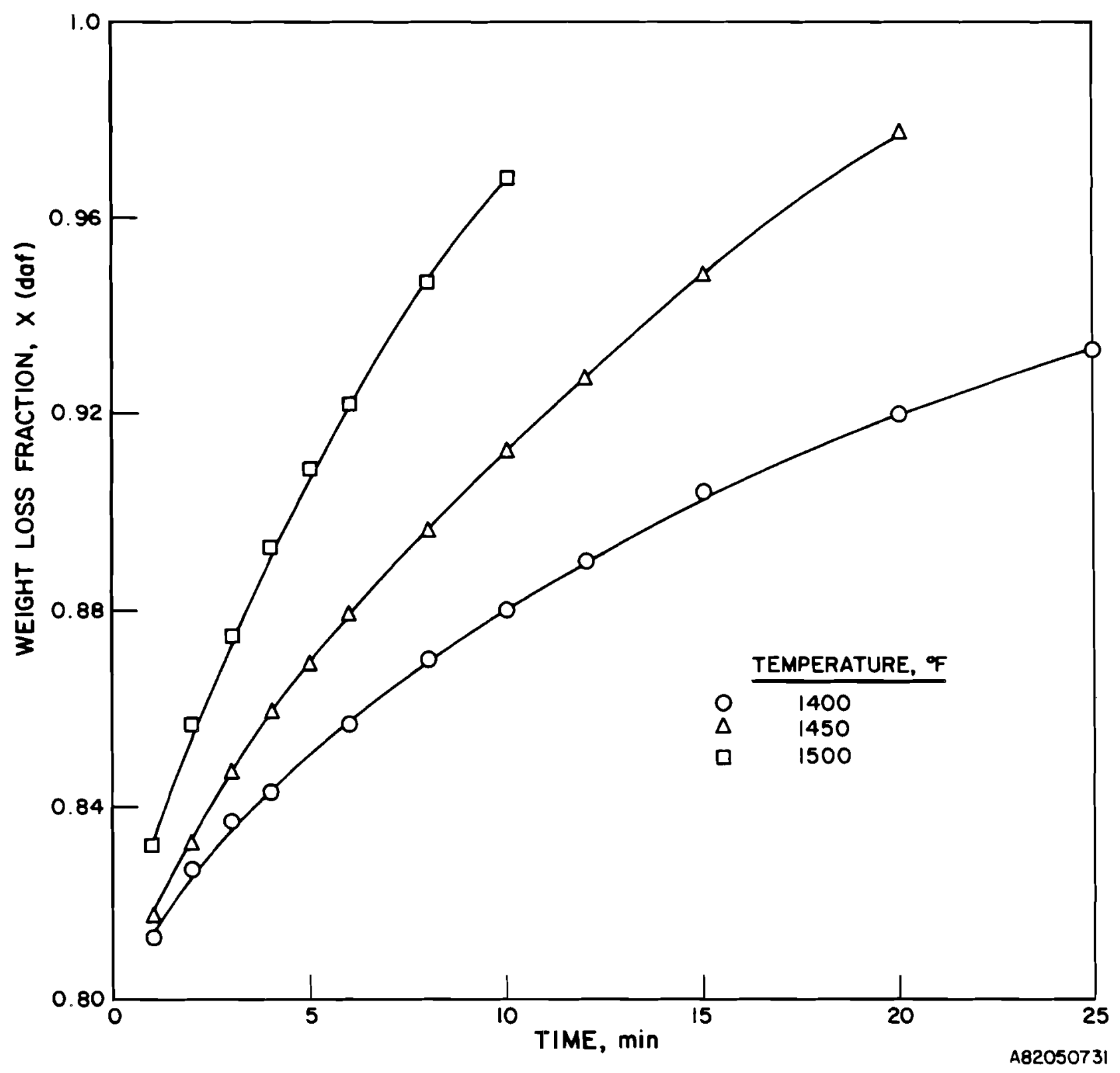

Figure 16. GASIFICATION OF IN-SITU CHAR FROM MAPLE HARDWOOD $(-12+16 \mathrm{Mesh})$ IN $10 \% \mathrm{H}_{2}+40 \% \mathrm{He}+50 \% \mathrm{H}_{2} \mathrm{O}$ AT 300 psig AND AT DIFFERENT TEMPERATURES 


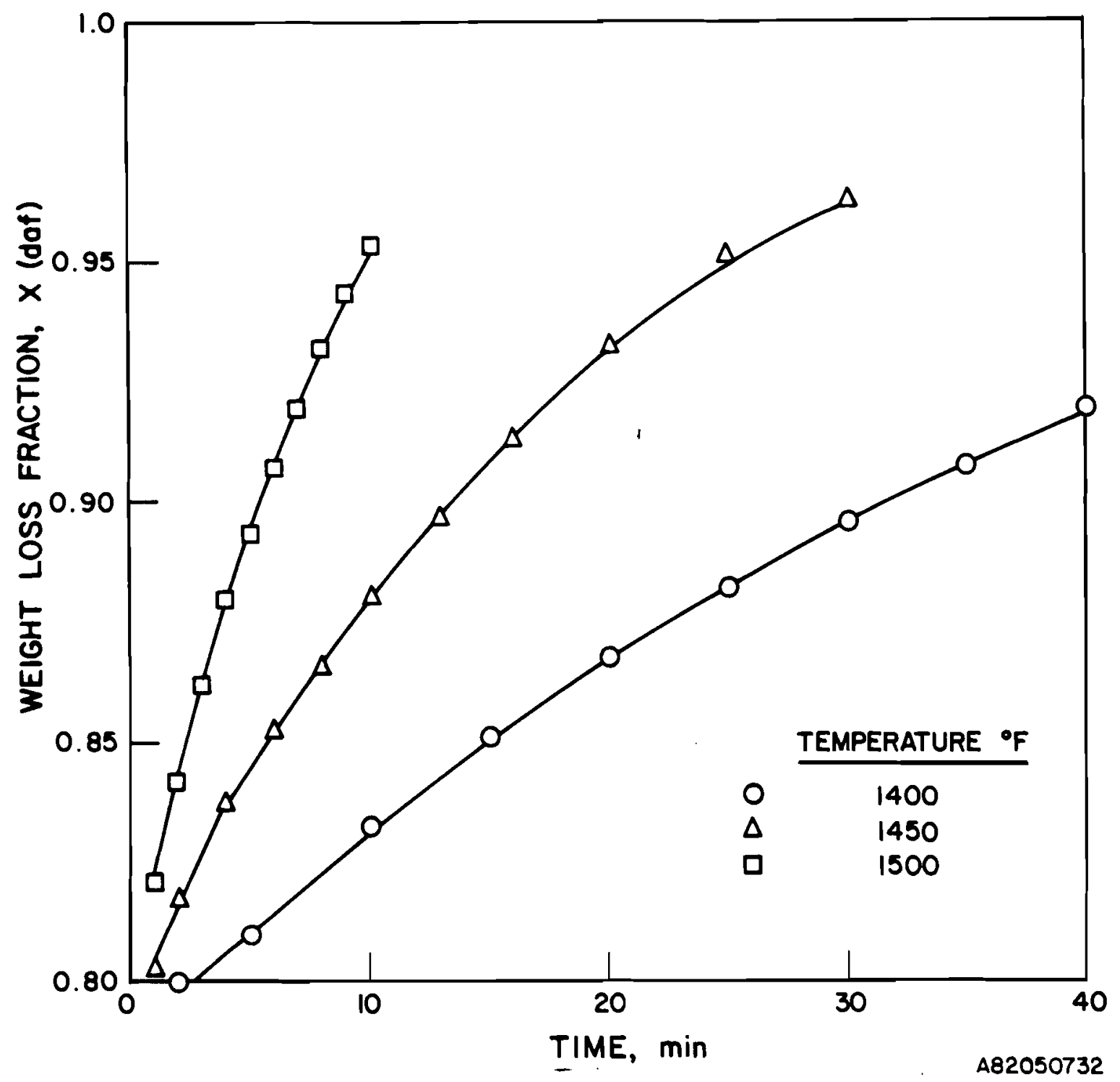

Figure 17. GASIFICATION OF IN-SITU CHAR FROM MAPLE HARDWOOD $(-12+16 \mathrm{Mesh})$ IN $25 \% \mathrm{H}_{2}+25 \% \mathrm{He}+50 \% \mathrm{H}_{2} \mathrm{O}$ AT 300 psig AND AT DIFFERENT TEMPERATURES 


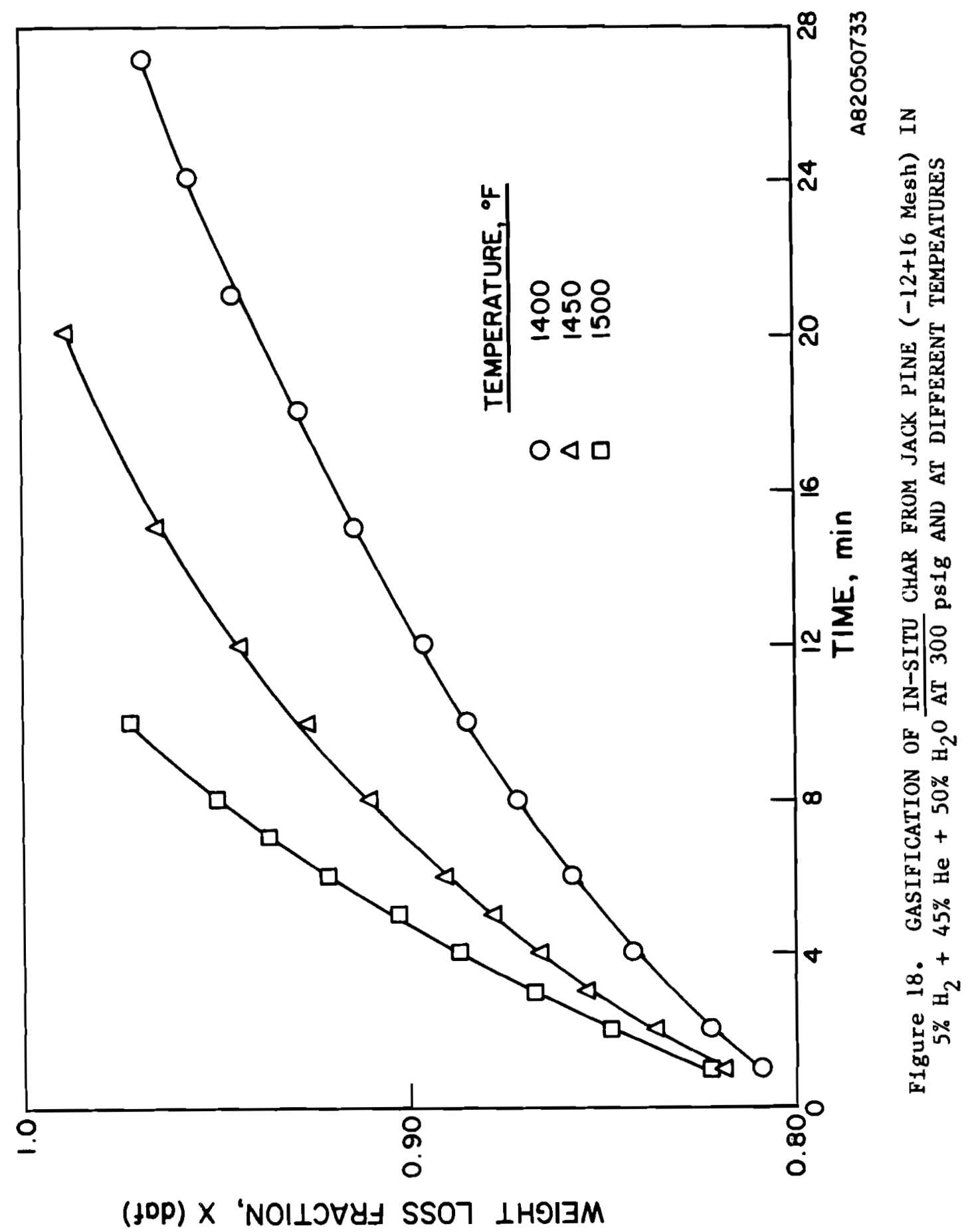




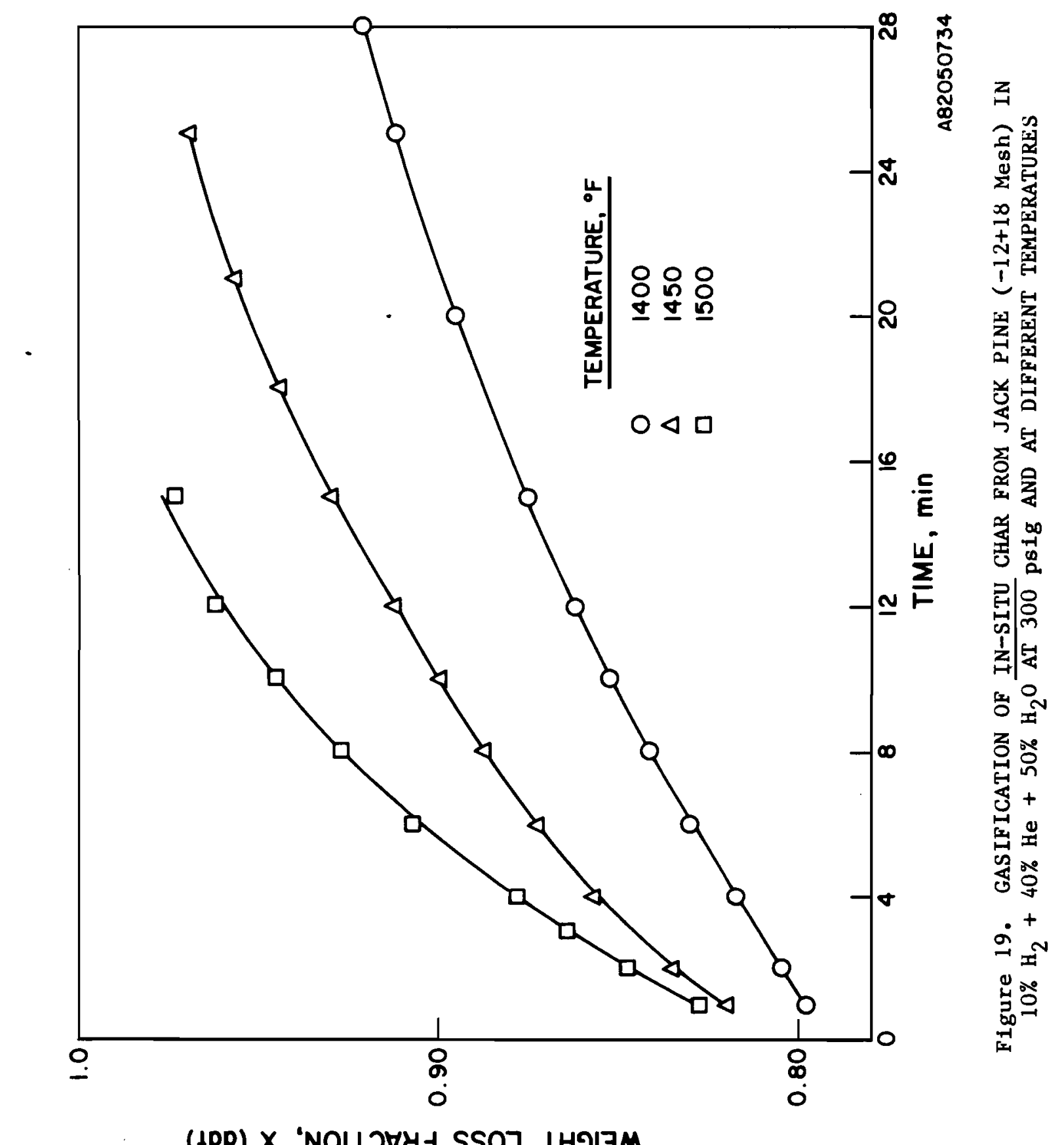




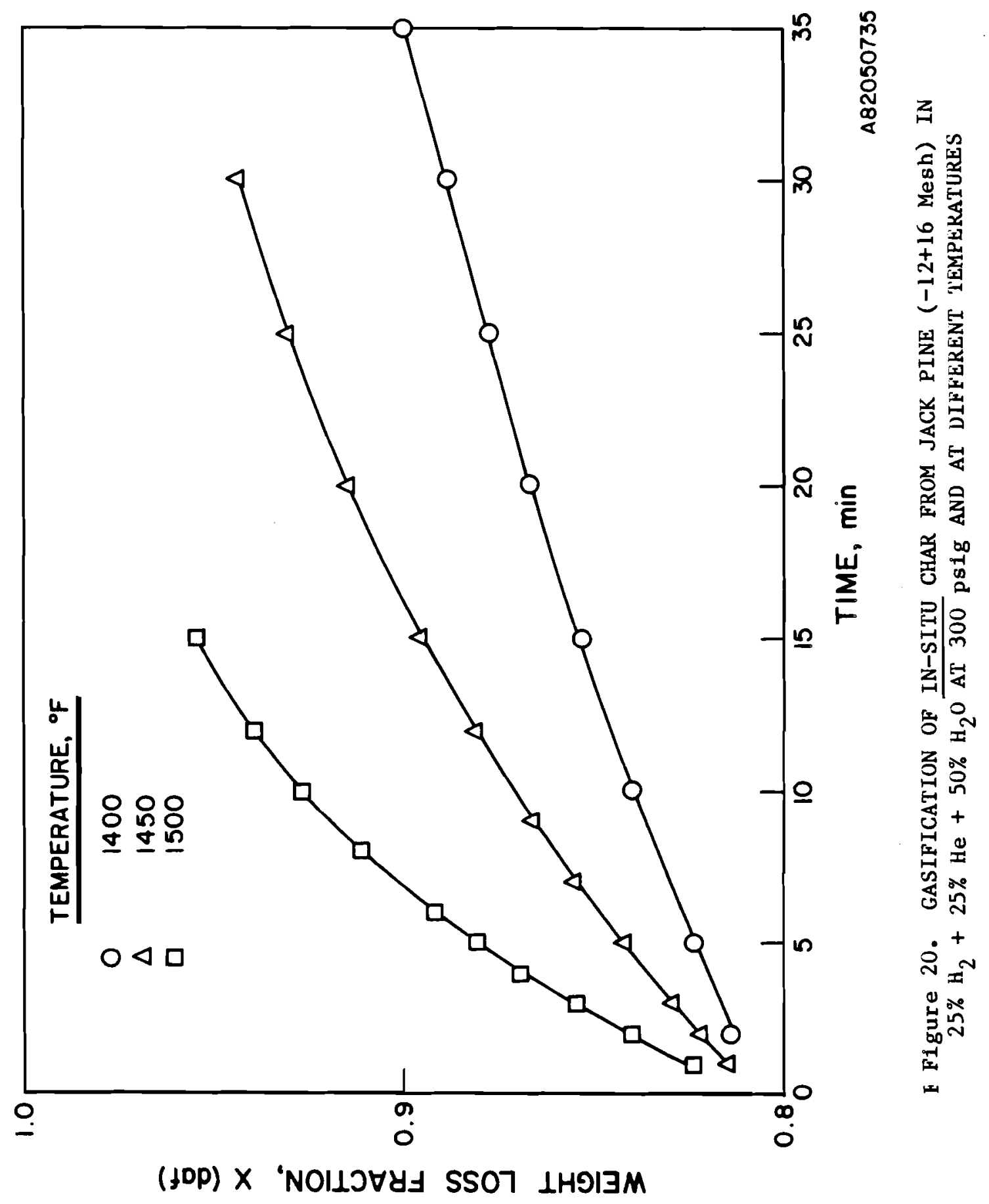


where -

$$
\begin{aligned}
& x_{c}=\text { weight loss fraction of char (daf) } \\
& t=\text { time, min } \\
& k=\text { reaction rate constant, } m^{-1}
\end{aligned}
$$

When starting with a raw wood sample to study "in-situ" char gasification the following definitions were used.

$X=$ total weight loss fraction (daf) of feed

$\mathrm{x}^{*}=$ weight loss of feed due to devolatilization

Therefore, the char carbon fraction is expressed as

$$
\mathrm{x}_{\mathrm{c}}=\left(\mathrm{x}-\mathrm{x}^{*}\right) /\left(1-\mathrm{x}^{*}\right)
$$

and from Equations 2 and 3

$$
-\ln (1-x)=-\ln \left(1-x^{*}\right)+k t
$$

Figure 21 is a plot according to Equation 4 of the typical experimental results shown in Figure 16. The data follow the straight lines, showing that the gasification reactions, are nearly first-order. The analyses and conclusions above were similar for all the experimental results presented in Figures 15 through 20 .

The values of all the first-order reaction rate constants, $k$, for maple and jack pine chars are presented in Table 9. The effect of pressure on $k$ was determined with the gas composition $5 \% \mathrm{H}_{2}+45 \% \mathrm{He}+50 \% \mathrm{H}_{2} \mathrm{O}$ for maple hardwood. The rest of the tests were conducted at $300 \mathrm{psig}$.

The Arrhenius equation was used to determine the apparent activation energy of the char gasification process in different gas mixtures:

$$
k=A \cdot e^{-E / R T}
$$

where -

$$
\begin{aligned}
& A=\text { preexponential factor } \\
& E=\text { apparent activation energy } \\
& R=\text { gas constant } \\
& T=\text { temperature, }{ }^{\circ} \mathrm{R}
\end{aligned}
$$




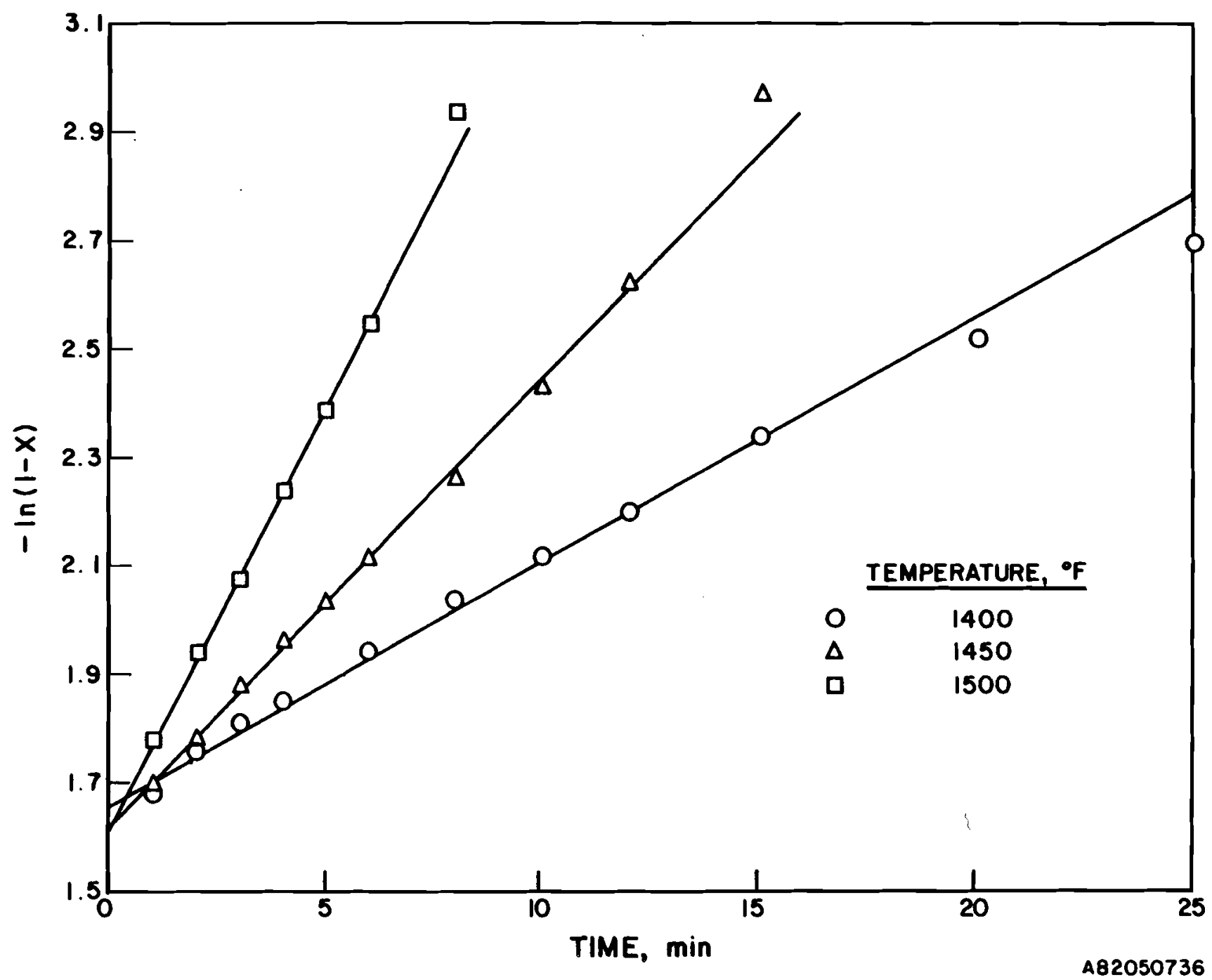

Figure 21. GASIFICATION OF MAPLE HAKDWOOD CHAR $(-12+16$ Mesh) IN GAS MIXTURE $\left(10 \% \mathrm{H}_{2}+40 \% \mathrm{He}+50 \% \mathrm{H}_{2}\right.$ ) AT A PRESSURE OF $300 \mathrm{psig}$ AND AT DIFFERENT TEMPERATURES - FIRST-OKDEK PLUT 
Table 9. REACTION RATE CONSTANT FOR THE GASIFICATION OF MAPLE HARDWOOD AND JACK PINE CHARS IN STEAM-HYDROGEN-HELIUM MIXTURES

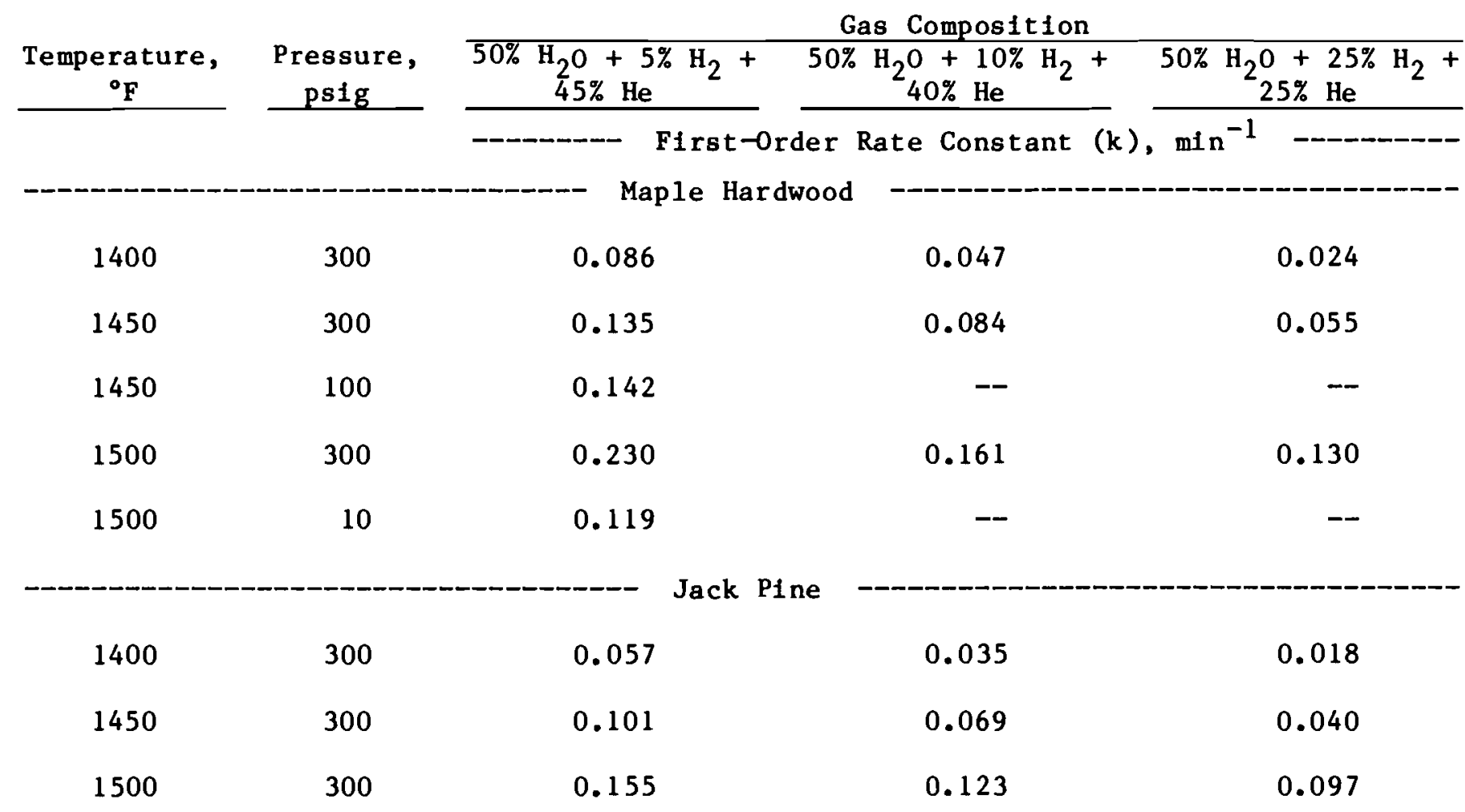

$171 / 65058 \mathrm{f}-\mathrm{t} / \mathrm{RPP}$ 
Taking the logarithm of Equation 5 yields -

$$
\ln k=\ln A-\frac{E}{R} \cdot \frac{1}{T}
$$

The data for maple hardwood are plotted according to the Arrhenius equation in Figure 22. Figure 23 is a similar plot for jack pine. The calculated values of $E$ (apparent activation energy) and $A$ (preexponential factor) are given in Table 10. The values obtained from the earlier steam gasification $\left(50 \% \mathrm{H}_{2} \mathrm{O}+\right.$ $50 \% \mathrm{~N}_{2}$ ) are also included for comparison. The value of $\mathrm{k}$ decreases with an increase in hydrogen concentration in this temperature range. At the same time, the apparent activation energy also increases with an increase in hydrogen concentration.

Table 10. APPARENT ACTIVATION ENERGY FOR THE GASIFICATION OF MAPLE HARDWOOD AND JACK PINE CHARS IN STEAM-HYDROGEN-HELIUM MIXTURES

$$
A, \min ^{-1} \quad \underline{E, B t u / 1 b-\operatorname{mol}}
$$

Gas Composition

Maple Hardwood

$$
\begin{array}{llr}
50 \% \mathrm{H}_{2} \mathrm{O}+50 \% \mathrm{~N}_{2} & 2.56 \times 10^{7} & 72,000 \\
50 \% \mathrm{H}_{2} \mathrm{O}+5 \% \mathrm{H}_{2}+45 \% \mathrm{He} & 2.44 \times 10^{7} & 72,500 \\
50 \% \mathrm{H}_{2} \mathrm{O}+10 \% \mathrm{H}_{2}+40 \% \mathrm{He} & 9.87 \times 10^{8} & 88,500 \\
50 \% \mathrm{H}_{2} \mathrm{O}+25 \% \mathrm{H}_{2}+25 \% \mathrm{He} & 2.14 \times 10^{12} & 119,500
\end{array}
$$

Jack Pine

$$
\begin{aligned}
& 50 \% \mathrm{H}_{2} \mathrm{O}+50 \% \mathrm{~N}_{2} \\
& 50 \% \mathrm{H}_{2} \mathrm{O}+5 \% \mathrm{H}_{2}+45 \% \mathrm{He} \\
& 50 \% \mathrm{H}_{2} \mathrm{O}+10 \% \mathrm{H}_{2}+40 \% \mathrm{He} \\
& 50 \% \mathrm{H}_{2} \mathrm{O}+25 \% \mathrm{H}_{2}+25 \% \mathrm{He}
\end{aligned}
$$$$
2.14 \times 10^{7}
$$$$
3.71 \times 10^{7}
$$$$
72,200
$$$$
1.97 \times 10^{9}
$$$$
75,500
$$$$
1.42 \times 10^{12}
$$$$
92,000
$$$$
119,000
$$

\section{Corn Stover Results}

A densified corn stover sample received from the University of California-Davis as 1-1/4-inch cubical pellets was ground to obtain a fraction of $-12+16$ mesh size for gasification tests. The ash content of this particular fraction was 7.75 weight percent, dry basis. As shown in previous characterization tests, the ash content of the total sample is probably higher in this fraction and is also expected to be greater in the smaller size fractions. 


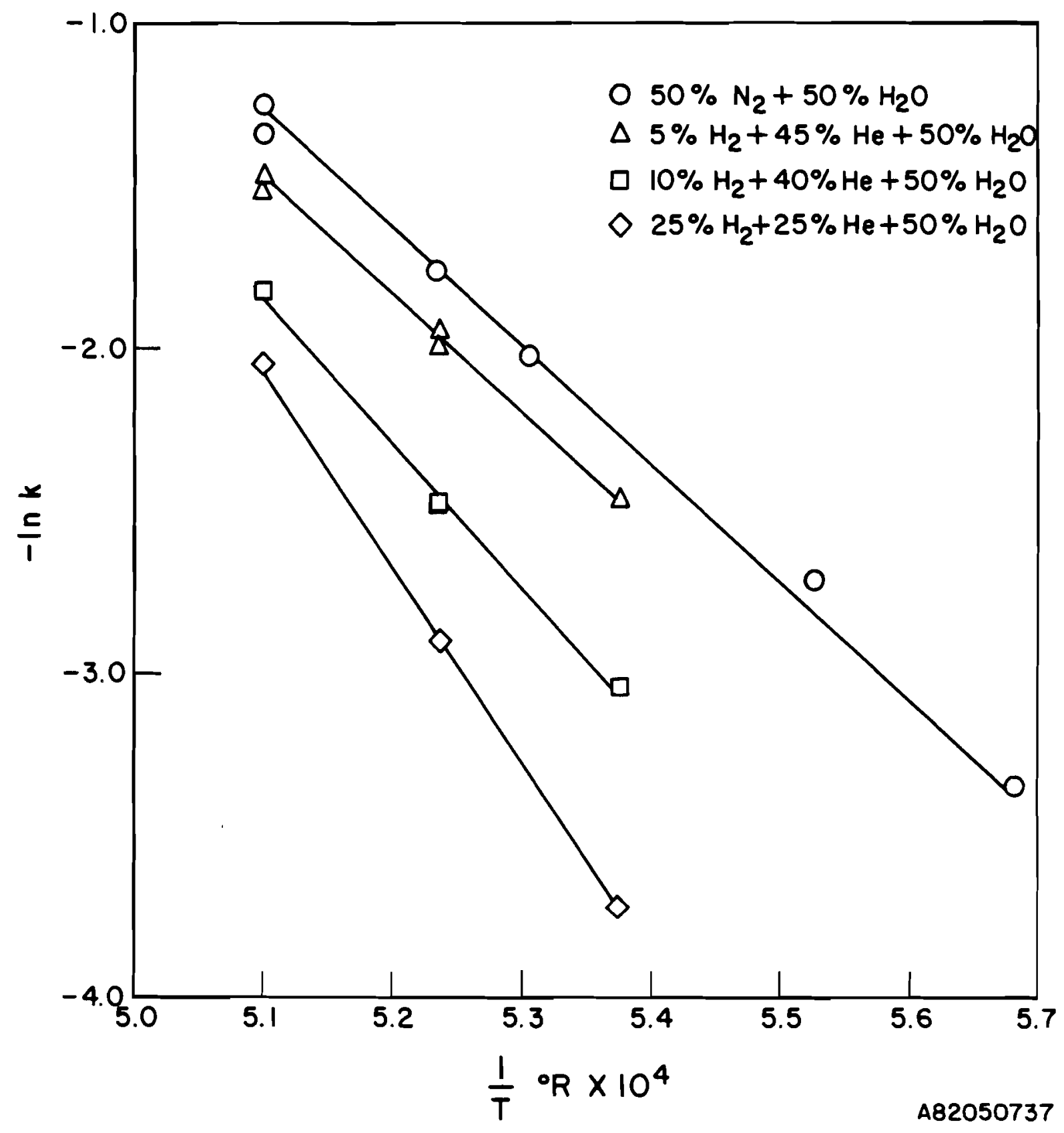

Figure 22. GASIFICATION OF MAPLE HARDWOOD CHAR $(-12+16$ Mesh) IN DIFFERENT GAS MEDIA - ARRHENIUS PLOT 


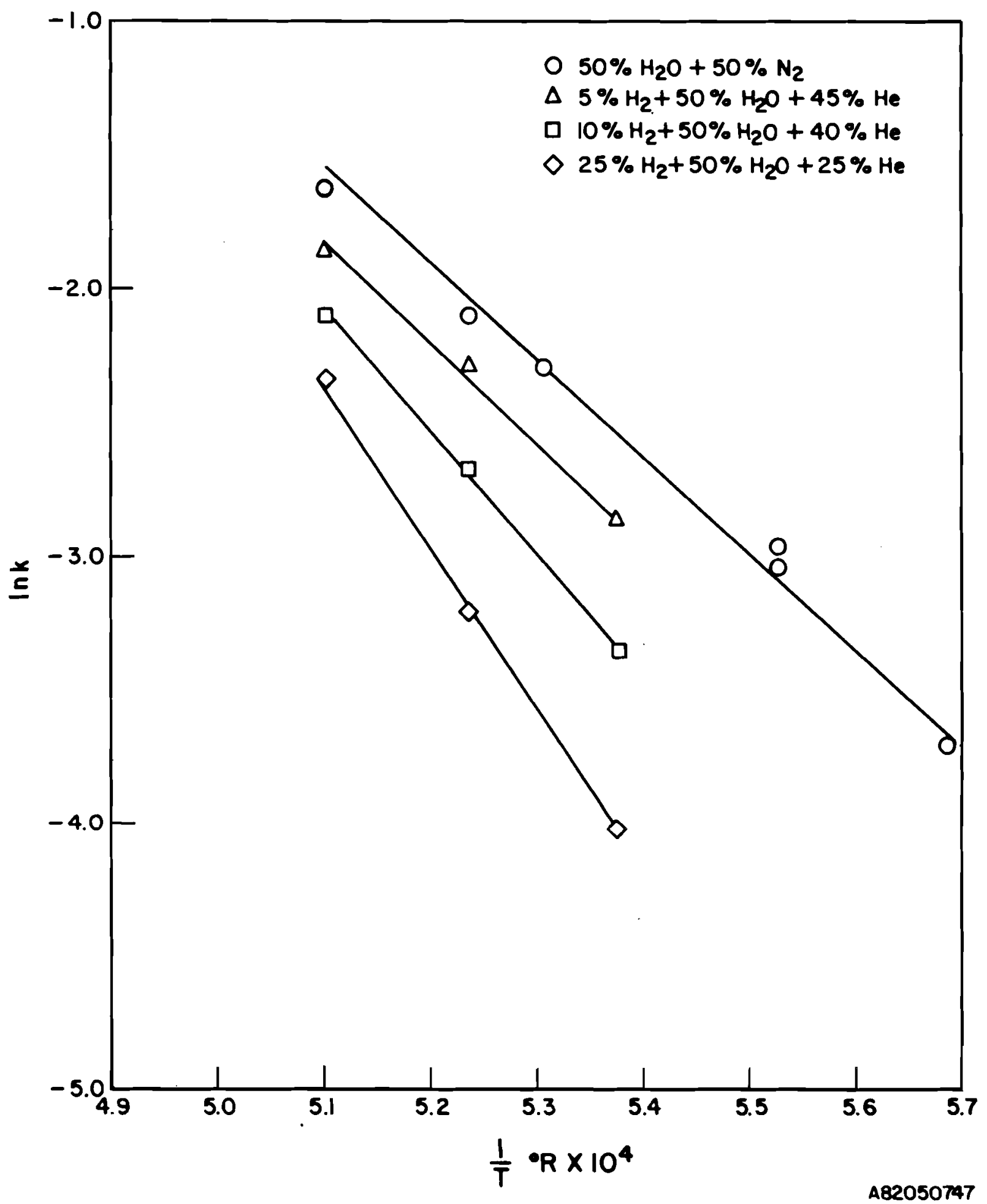

Figure 23. GASIFICATION OF JACK PINE CHAR (-12+16 Mesh) IN DIFFERENT GAS MEDIA - ARRHENIUS PLOT 
The gasification experiments were conducted in the temperature range from $1300^{\circ}$ to $1700^{\circ} \mathrm{F}$ at a pressure of 300 psig according to the in-situ procedure described earlier. Three gasification media were used for corn stover char with the following compositions, 1) $50 \% \mathrm{H}_{2} \mathrm{O}$ and $\left.50 \% \mathrm{~N}_{2} ; 2\right) 50 \% \mathrm{H}_{2} \mathrm{O}, 5 \% \mathrm{H}_{2}$, and $45 \% \mathrm{He}$; and 3) $50 \% \mathrm{H}_{2} \mathrm{O}, 10 \% \mathrm{H}_{2}$, and $40 \% \mathrm{He}$.

The experimental results for the ground sample of the densified corn stover cubes are presented in Figures 24 through 27 for various temperatures. The weight-loss fractions (daf) are plotted against reaction time in these figures. The gasification characteristics of the in-situ chars from the corn stover sample are markedly different from those of maple and jack pine, as was concluded also from the previous experimentation with the laboratory-prepared or stabilized chars of the biomass materials.

The calculated function $-\ln (1-X)$, when plotted, 1llustrates how the first-order equation used for the woody materials represents the corn stover data poorly and indicates a different behavior. Figure 28 is a typical plot of $-\ln (1-X)$ versus reaction time, $t$, for reaction Medium 2. For gasification temperatures $1600^{\circ}$ and $1700^{\circ} \mathrm{F}$, the experimental points are nearly linear, that is, at $1600^{\circ} \mathrm{F}$ or higher temperatures, the reaction was nearly first-order in $X$. The gasification characteristics for the other mixtures with corn stover char are qualitatively similar to that shown in Figure 26.

This initial attempt of the analysis of the corn stover data by a firstorder model did not describe the behavior adequately over all times or conversions. The model did not describe the complete gasification range (that 1s, all values of $\mathrm{X}$ ). To account for the overall kinetic behavior of densified corn stover, another model was developed, which is similar to that developed for 1ignite gasification. ${ }^{7}$ It is based on the assumption that two types of entities exist in the feed and are gasified sequentially. Let -

$$
\begin{aligned}
& \mathrm{X}=\text { total feed conversion, } \mathrm{dry} \text { ash-free basis } \\
& \mathrm{X}_{\mathrm{O}}=\text { total conversion due to devolatilization } \\
& \mathrm{Y}=\text { conversion of char. }
\end{aligned}
$$

From these definftions, then -

$$
Y=\left(X-X_{0}\right) /\left(1-X_{0}\right)
$$




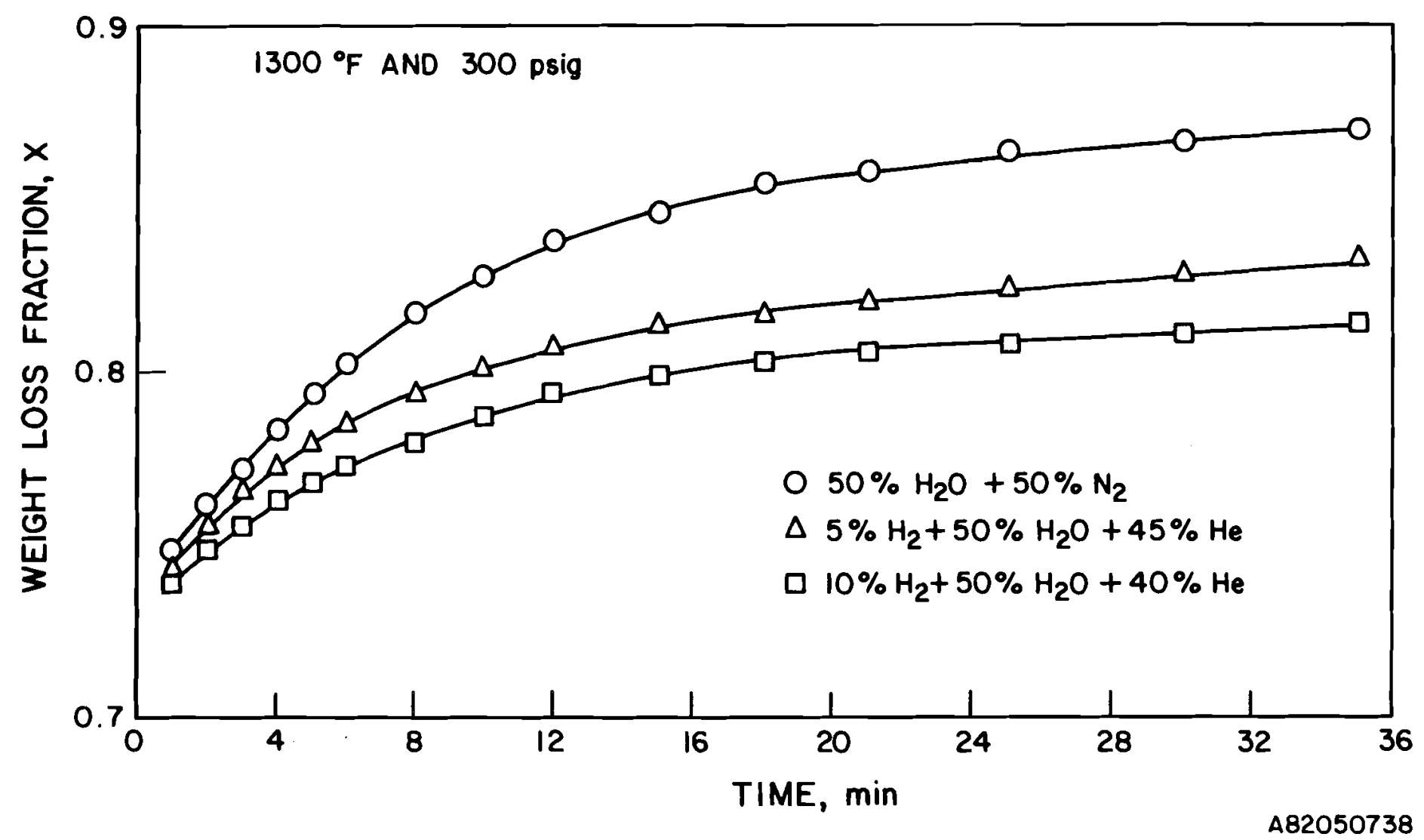

F1gure 24. GASIFICATION OF IN-SITU CHAR FROM DENSIFIED CORN STOVEK AT $1300^{\circ}$ AND AT A PRESSURE OF $\overline{300 \mathrm{ps} 1 \mathrm{~g}}$ WITH DIFFERENT REACTION GAS MEDIA 


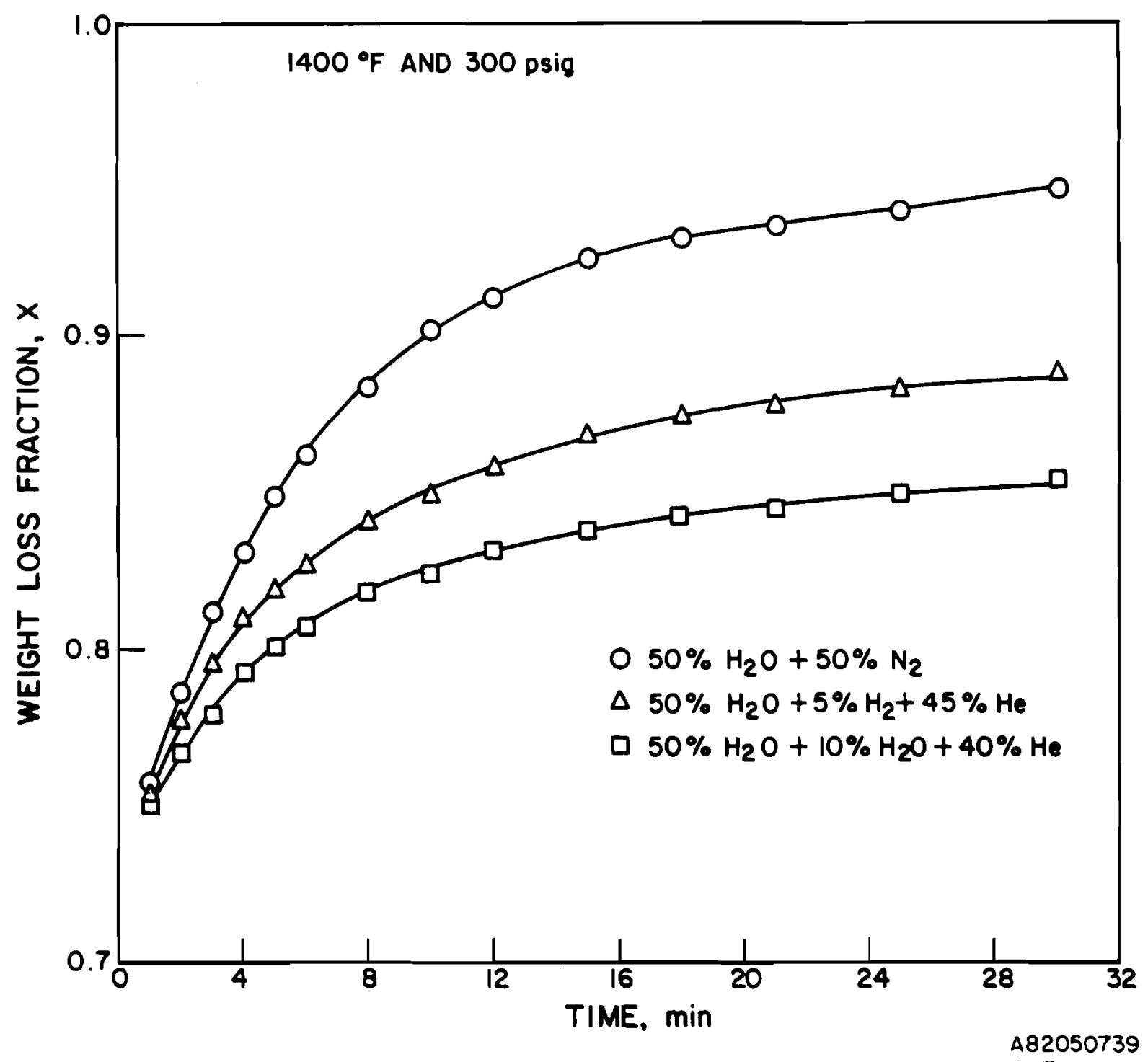

FIgure 25. GASIFICATION OF IN-SITU CHAR FROM DENSIFIED CORN STOVER AT

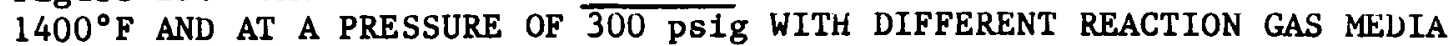




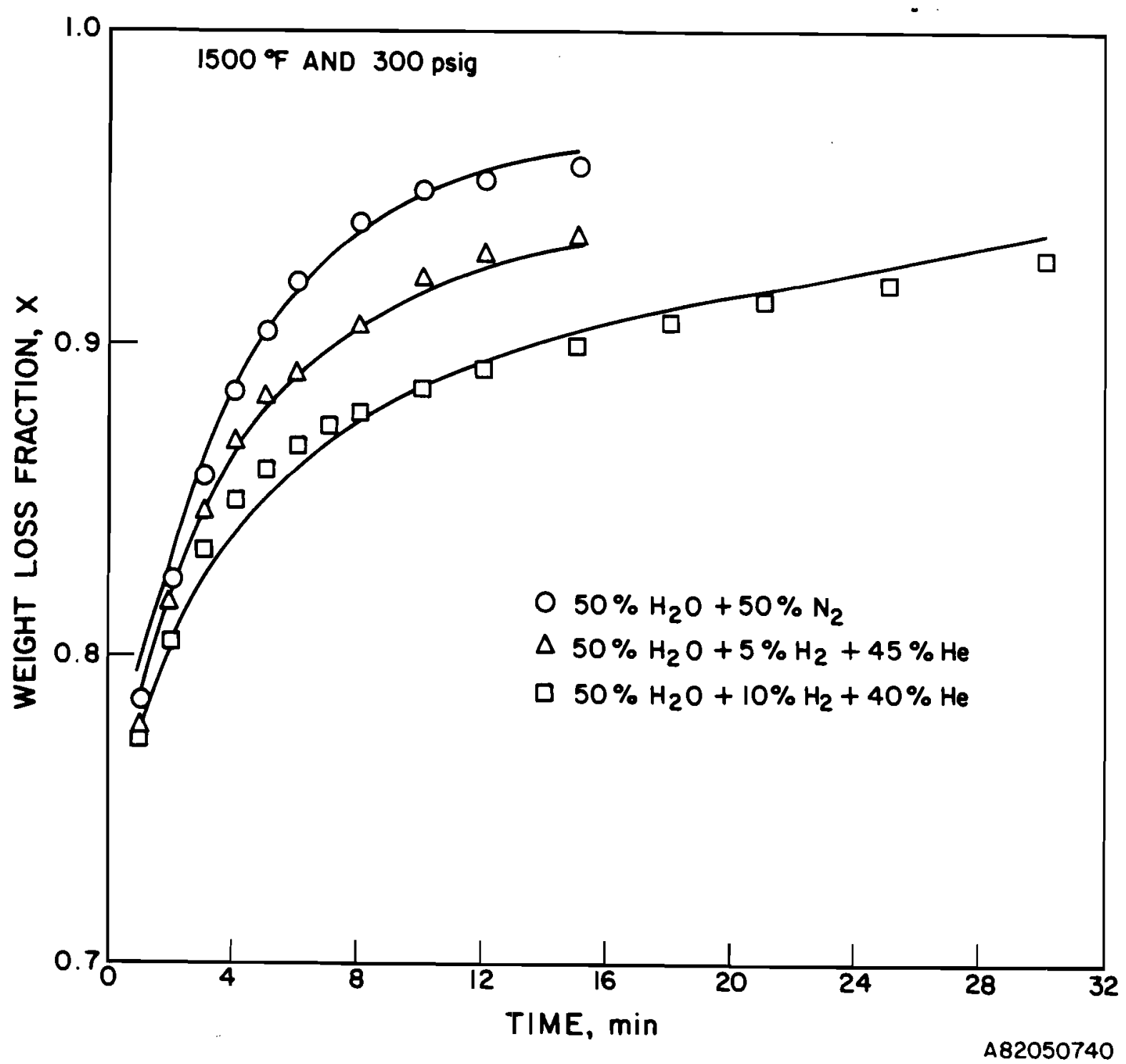

Figure 26. GASIFICATION OF IN-SITU CHAR FROM DENSIFIED CORN STOVER AT $1500^{\circ} \mathrm{F}$ AND AT A PRESSURE OF 300 psig WITH DIFFERENT REACTION GAS MEDIA 

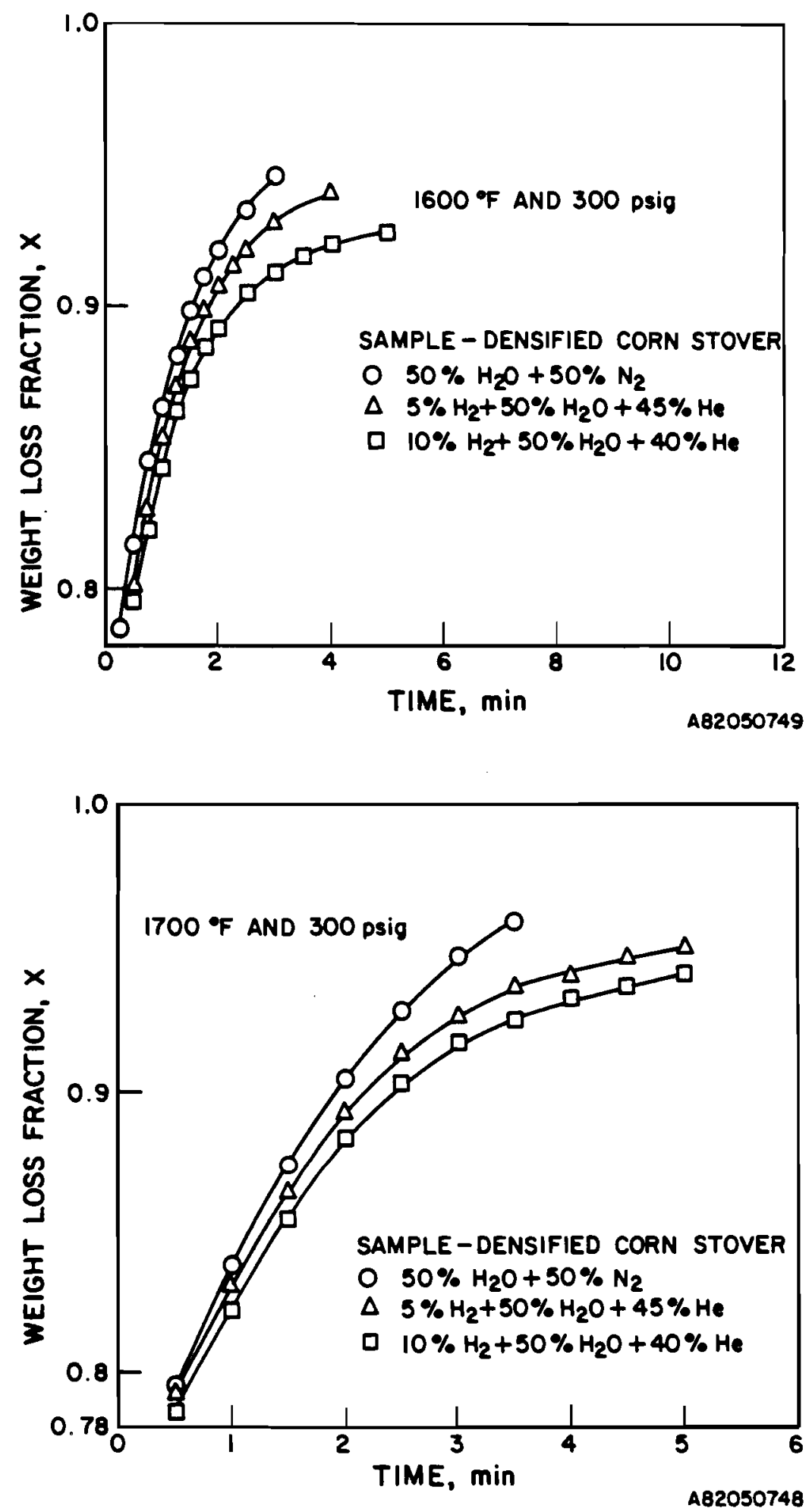

Figure 27. GASIFICATION OF IN-SITU CHAR FROM DENSIFIED CORN STOVER AT 300 psIg WITH DIFFERENT REACTION GAS MEDIA 


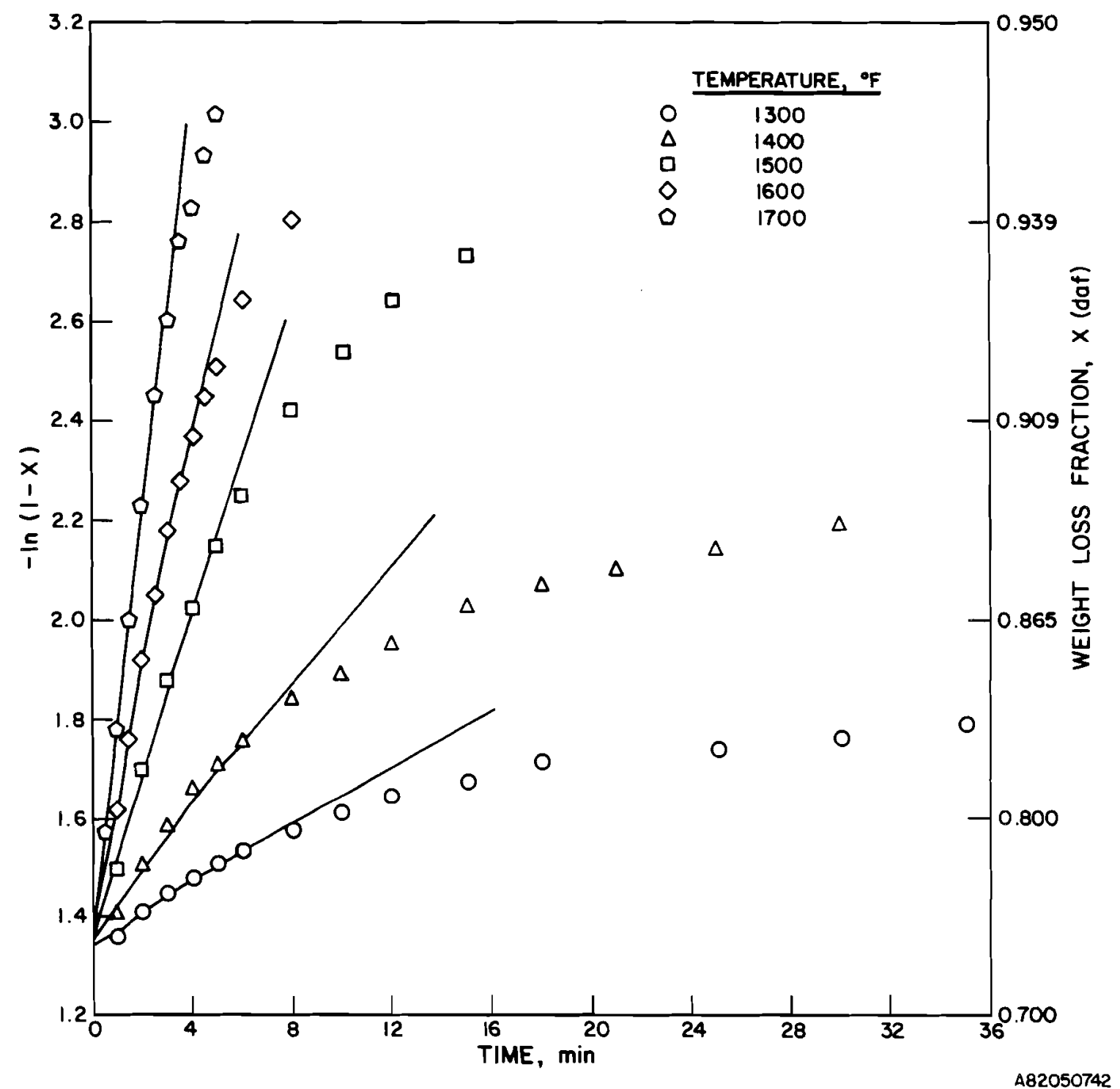

FIgure 28. GASIFICATION OF IN-SITU CHAR FROM DENSIFIED CORN STOVER WITH $50 \% \mathrm{H}_{2} \mathrm{O}, 5 \% \mathrm{H}_{2}$, and $45 \%$ He AT A PRESSURE OF 300 psig AND AT DIFFERENT TEMPERATURES - LIMITATIONS OF FIRST-ORDER FIT 
Hence, the proposed model assumes that the char can gasify by two routes:

$$
\begin{array}{ll}
\text { Char }-\mathrm{K}_{2} \rightarrow \text { Gaseous Products } & \text { (Reaction I) } \\
\text { Char } \stackrel{\mathrm{K}_{1}^{*}}{-\mathrm{n}^{*}}->\text { Gaseous Products } & \text { (Reaction II) }
\end{array}
$$

Reaction $I$ is uncatalyzed first-order reaction. Reaction II corresponds to a path in which some entity, $n^{*}$, catalyzes gasification. The rate of this reaction is $k_{1}^{*}$. The catalytic entity is assumed to be some structural component present in the char rather than some inorganic catalytic materials.

The overall gasification rate of the char is then described by the expressions -

$$
\mathrm{dY} / \mathrm{dt}=\left(\mathrm{K}_{2}+\mathrm{K}_{1}^{\star} \mathrm{C}_{\mathrm{n}}\right)(1-\mathrm{Y})
$$

where -

$$
\begin{aligned}
C_{n *} & =\text { concentration of catalytic entity, } n^{*} \text {, in char } \\
t & =\text { time, min. }
\end{aligned}
$$

Additionally, it is assumed that $\mathrm{n}^{*}$ deactivates by a first-order process, consistent with the expression -

$$
\mathrm{dC}_{n *} / \mathrm{dt}=\left(-\mathrm{K}_{0}^{*}\right) \mathrm{C}_{\mathrm{n}}
$$

where -

$$
\mathrm{K}^{*}{ }_{0}=\text { rate constant, } \min ^{-1} \text {. }
$$

Integrating Equation 9 at constant environmental conditions yields -

$$
c_{n *}=c_{n *}^{0} \exp \left(-K_{0}^{*} t\right)
$$

where -

$$
c_{n *}^{0}=\text { initial concentration of } n^{*} \text {. }
$$

Substituting Equation 10 into Equation 6 and integrating provides -

$$
-\ln (1-Y)=K_{2} t+\frac{K_{1}^{*} C_{n \star}^{0}}{K_{0}^{*}}\left[1-\exp \left(-K_{0}^{*} t\right)\right]
$$


From Equation 7 -

$$
-\ln (1-Y)=-\ln \left(1-X_{0}\right) /\left(1-X_{0}\right)
$$

Therefore -

$$
-\ln (1-x)=-\ln \left(1-x_{0}\right)+k_{p}\left[1-\exp \left(-k_{0}^{\star} t\right)\right]+k_{2} t
$$

where -

$$
\mathrm{K}_{\mathrm{p}}=\frac{\mathrm{k}_{1}^{\star} \mathrm{c}_{\mathrm{n}^{\star}}^{\mathrm{o}}}{\mathrm{k}_{\mathrm{o}}^{\star}}
$$

The experimental results presented in Figures 17 through 24 were analyzed via Equation 13, and the parameters $K_{p}, K_{0}^{*}$, and $K_{2}$ were evaluated for different gasification conditions. The values are given in Table 11. The value of $-\ln \left(1-x_{0}\right)$ was equal to 1.34 under all experimental conditions, a result similar to that of the first-order approach. The data fit are clearly satisfactory as shown in Figures 29 and 30.

As mentioned earlier, gasification results of stabilized chars (chars prepared by separate devolatilization in nitrogen) of corn stover in a gas mixture of $50 \% \mathrm{H}_{2} 0,5 \% \mathrm{H}_{2}$, and $45 \%$ He were reported previously. The data were reevaluated according to the model represented by Equation 13. As the stabilized char was devolatilized before gasification, the first term on the right-hand side of Equation 13 for the laboratory-prepared char will be zero. The other parameters of Equation 13 were evaluated from the experimental results for the gasification of stabilized chars from corn stover. The values are given in Table 12.

The values of the parameters shown in Table 12 were used to calculate the stabilized char curves shown in Figure 29; the experimental values of $X$ are shown by data points. The fit appears satisfactory. Although Equation 13 is unquestionably empirical, it is useful as a model for estimating the residence time in a reactor for a certain conversion under known conditions.

Comparison of the parameters for gasification of in-situ chars and stabilized chars in Tables 11 and 12 shows that the stabilized chars are less reactive than the in-situ chars. This is graphically illustrated in Figure 30. The conversion for the in-situ char at $1500^{\circ} \mathrm{F}$ appears to take about 1.5 times longer than for the stabilized chars. 
Table 11. THE VALUES OF KINETIC PARAMETERS FOR THE GASIFICATION OF IN-SITU CHARS FROM DENSIFIED CORN STOVER IN DIFFERENT MEDIA

\begin{tabular}{|c|c|c|c|c|c|c|c|c|c|}
\hline \multirow{3}{*}{ 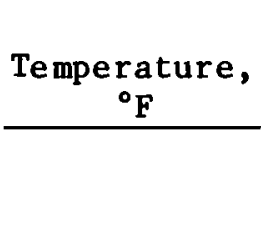 } & & \multicolumn{3}{|c|}{ Medium 2} & \multicolumn{3}{|c|}{ Medium 3} \\
\hline & $(50 \%$ & $\begin{array}{l}\text { Medium } \\
{ }_{2} \mathrm{O} \text { and }\end{array}$ & $\begin{array}{l}1 \\
\left.50 \% N_{2}\right) \\
\end{array}$ & $(50 \%$ & $\begin{array}{ll}0, & 5 \\
5 \% & \mathrm{H} \\
\end{array}$ & $\mathrm{H}_{2}$, and & $(50 \%$ & $\begin{array}{l}0,1 \\
40 \%\end{array}$ & $\mathrm{H}_{2}$, and \\
\hline & $K_{p}$ & $\mathrm{~K}_{0}^{*}$ & $\mathrm{~K}_{2}$ & $\mathrm{~K}_{\mathrm{p}}$ & $K_{0}^{*}$ & $\mathrm{~K}_{2}$ & $\mathrm{~K}_{\mathrm{p}}$ & $\mathrm{K}_{0}^{\star}$ & $\mathrm{K}_{2}$ \\
\hline 1300 & 0.40 & 0.14 & 0.0095 & 0.27 & 0.15 & 0.0051 & 0.18 & 0.14 & 0.0060 \\
\hline 1400 & 0.60 & 0.17 & 0.0400 & 0.54 & 0.19 & 0.0105 & 0.35 & 0.18 & 0.0094 \\
\hline 1500 & 0.86 & 0.20 & 0.0920 & 0.90 & 0.23 & 0.0330 & 0.66 & 0.22 & 0.0250 \\
\hline 1600 & & $\begin{array}{l}\text { ation } \\
\text { pplical }\end{array}$ & $\begin{array}{l}3 \text { not } \\
1 e^{\text {not }}\end{array}$ & 0.90 & 0.29 & 0.0850 & 0.85 & 0.28 & 0.0640 \\
\hline 1700 & & $\begin{array}{l}\text { ation } \\
\text { pplical }\end{array}$ & $\begin{array}{l}3 \text { not } \\
1 e^{-}\end{array}$ & & $\begin{array}{l}\text { tion } \\
\text { plice }\end{array}$ & $\begin{array}{l}3 \text { not } \\
\text { le }\end{array}$ & 0.90 & 0.40 & 0.1500 \\
\hline
\end{tabular}




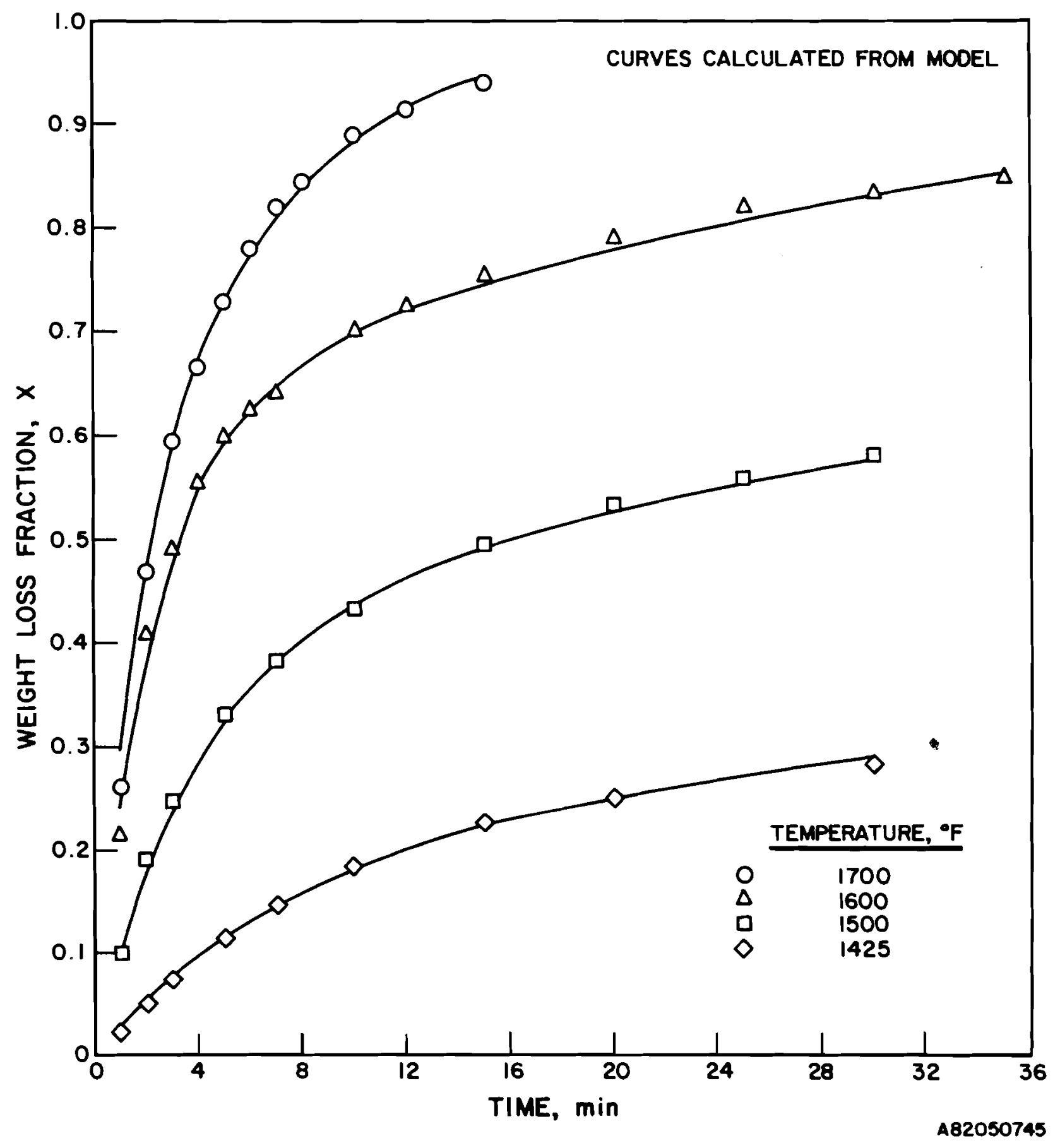

Figure 29. GASIFICATION OF STABILIZED CHAR FROM CORN STOVER WITH $5 \% \mathrm{H}_{2}+45 \% \mathrm{He}+50 \% \mathrm{H}_{2} \mathrm{O}$ AT 300 psig AND AT DIFFERENT TEMPERATURES 


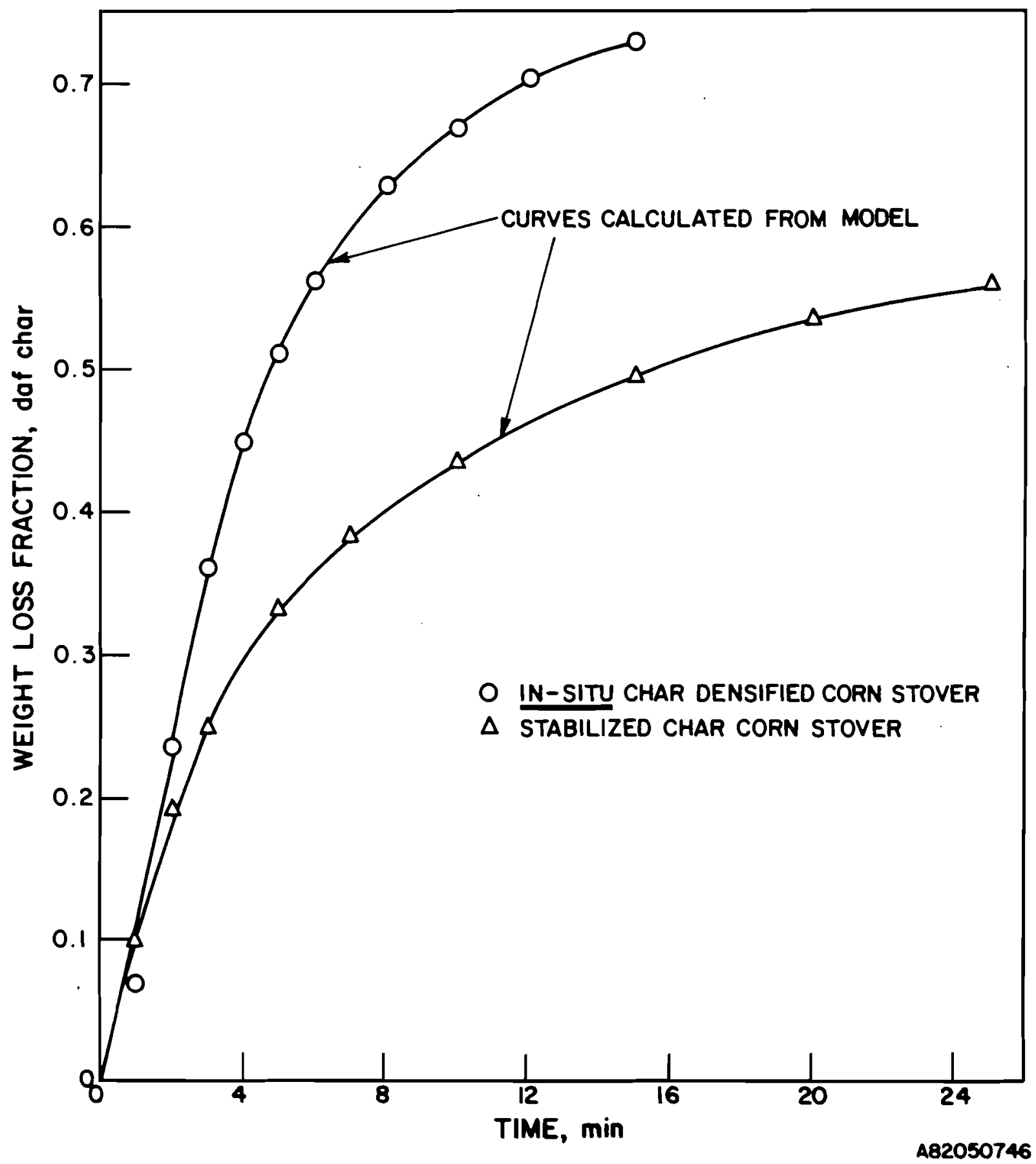

Figure 30. COMPARISON OF THE GASIFICATION OF STABILIZED CHAR FROM CORN STOVER WITH IN-SITU CHAR FROM DENSIFIED CORN STOVER AT $1500^{\circ} \mathrm{F}$ AND AT A PRESSURE OF 300 psig IN A GAS MIXTURE CONTAINING $5 \% \mathrm{H}_{2}, 45 \% \mathrm{He}$, AND $50 \% \mathrm{H}_{2} \mathrm{O}$ 
Figure 31 provides a comparison of the relative reactivities of the ins1tu chars obtained from the three biomass species with that of peat char and of bituminous coal char. The in-situ chars of the blomass species, as is generally known, are much more reactive than the peat char, which in turn $1 \mathrm{~s}$ more reactive than the bituminous coal char. In this study the in-situ

\section{Table 12. THE VALUES OF THE KINETIC PARAMETERS FOR THE GASIFICATION OF STAB ILIZED CHARS FROM CORN STOVER IN $50 \% \mathrm{H}_{2} \mathrm{O}, 5 \% \mathrm{H}_{2}$, AND $45 \%$ He AT DIFFERENT TEMPERATURES}

\begin{tabular}{|c|c|c|c|}
\hline$\underset{\substack{0 \\
{ }^{\circ}}}{\text { Temperature, }}$ & $K_{p}$ & $\mathrm{k}_{\mathrm{o}}^{*}$ & $\mathrm{~K}_{2}$ \\
\hline 1425 & 0.24 & 0.12 & 0.0037 \\
\hline 1500 & 0.54 & 0.20 & 0.0107 \\
\hline 1600 & 0.98 & 0.30 & 0.0271 \\
\hline 1700 & 0.60 & 0.40 & 0.1567 \\
\hline
\end{tabular}

blomass chars were found to be about 1.5 to 2.5 times more reactive than the stabilized, laboratory-prepared chars.

Char Surface-Area Measurements

The surface areas and total open pore volumes of the stabilized, laboratory-prepared chars of maple hardwood were determined. The chars were prepared by devolatilization of maple hardwood $(-12+16$ mesh) in nitrogen at I various temperatures from $1350^{\circ}$ to $1700^{\circ} \mathrm{F}$.

An Arrhenius plot of the rate of gasification of the maple hardwood chars was linear for gasification temperatures from $1350^{\circ}$ up to $1500^{\circ} \mathrm{F}$. The Inearly extrapolated value of the rate at $1700^{\circ} \mathrm{F}$ was higher, however, than the experimentally determined value. Table 13 lists the measured surface areas and pore volumes of the chars along with measurements of particle and true densities.

The nitrogen surface area was determined from adsorption of n1trogen at $-320^{\circ} \mathrm{F}$, using the BET equation. The carbon dioxide surface area was determined from the adsorption of carbon dioxide at $77^{\circ} \mathrm{F}$ with the DubininPolanzi equation. The total open pore volume was calculated from the mercury density and hellum density values of the chars. 


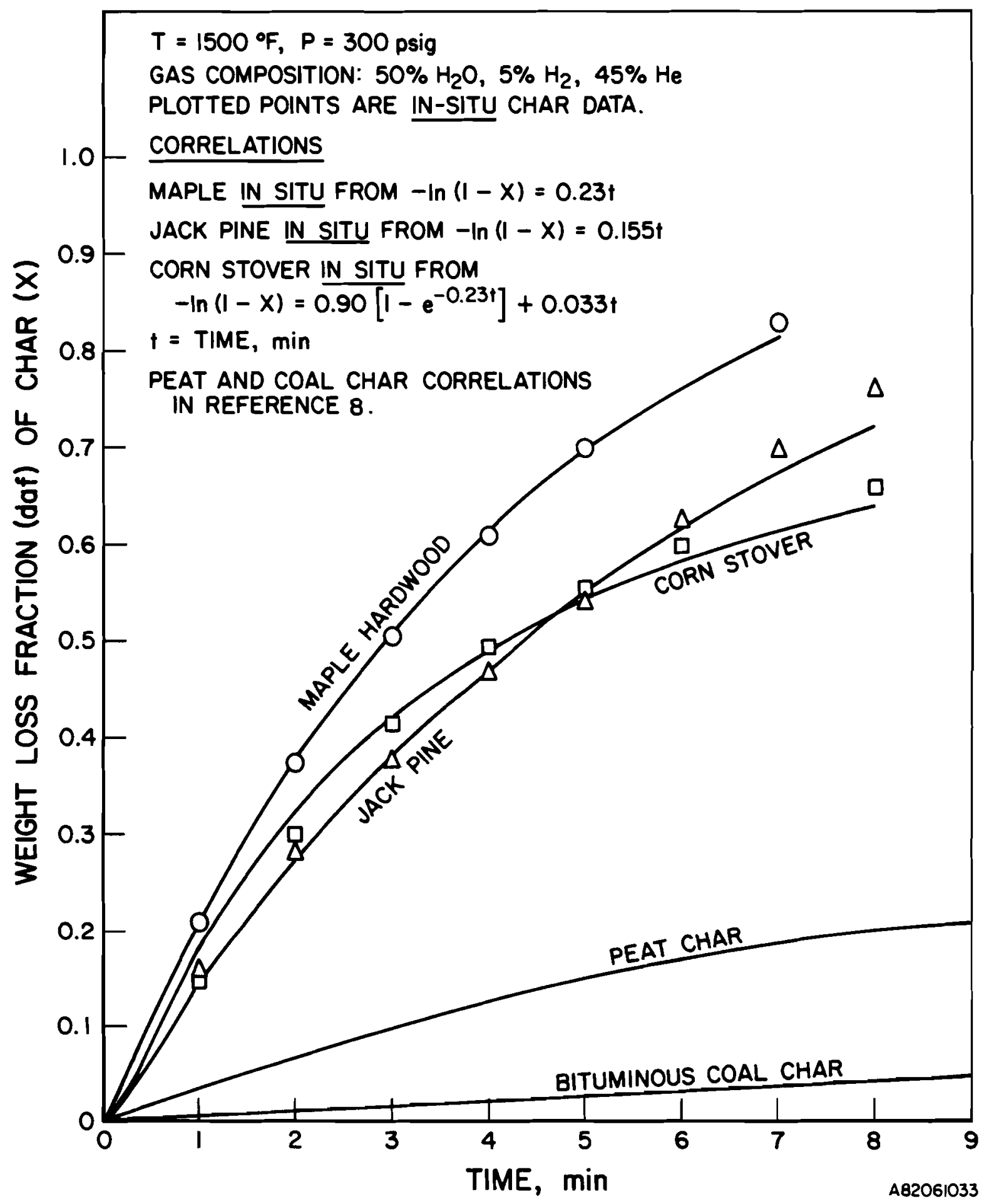

F1gure 31. COMPARISON OF THE GASIFICATION RATES OF JACK PINE, MAPLE HARDWOOD, AND CORN STOVER IN-SITU CHARS WITH PEAT AND BITUMINOUS COAL CHARS 


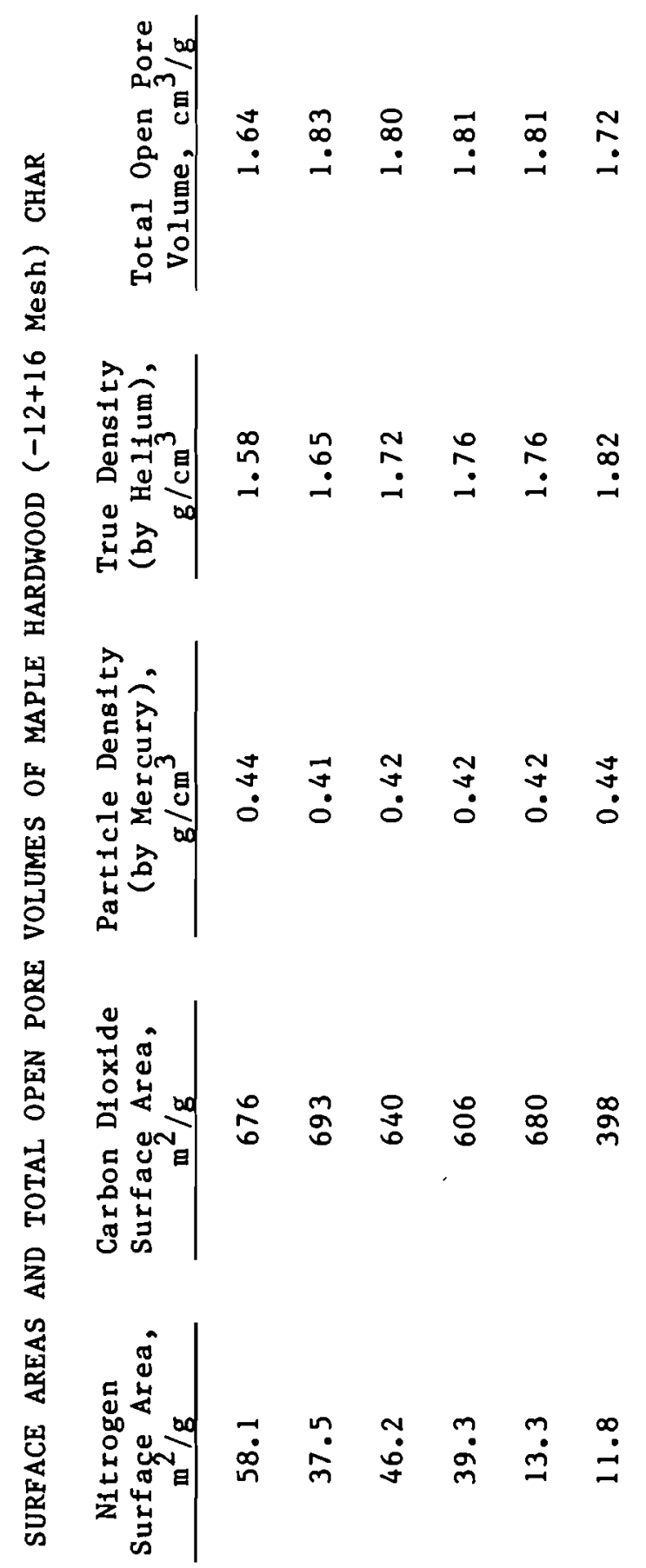

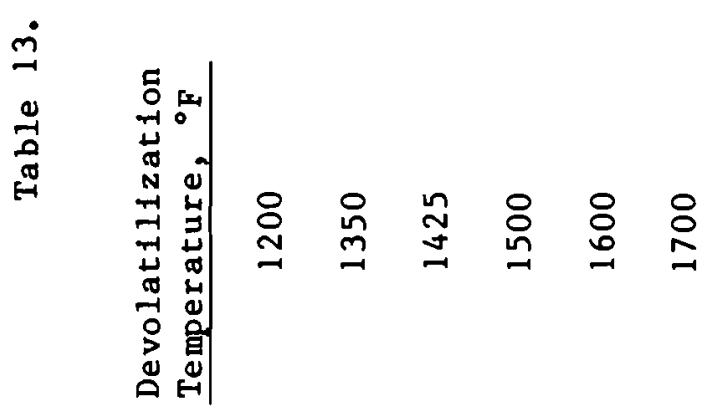

章 
In general, the nitrogen surface area values are smaller than the carbon dioxide values. Similar differences between the nitrogen and carbon dioxide values have been observed for coals ${ }^{9}$ and low-temperature coal chars. 10 It has been hypotheslzed that the n1trogen molecules at the low-temperature could not diffuse into all the micropores of coal and the low-temperature coal char. Hence, the carbon dioxide surface area, measured at room temperature, can be considered to account for most of the total surface area of the maple hardwoodchars. The nitrogen surface area can be considered to account for the geometric surface area of the particles plus the area of the relatively larger pores. It has been indicated 11 that the intermediate-sized pores ( $20 \AA$ to $40 \AA$ In diameter) work as a feeder or distributor for gas transport to the micropores.

As Table 13 shows that for maple hardwood laboratory-prepared chars, the carbon dioxide surface area values remain high up to a devolatilization temperature of $1600^{\circ} \mathrm{F}$. The measured value decreases only for the $1700^{\circ} \mathrm{F}$ char. The change in the nitrogen surface area value was relatively small for the chars prepared at up to $1500^{\circ} \mathrm{F}$, beyond which there is a significant decrease in the surface area values. The total open pore volumes of the chars as calculated remain almost unchanged from $1350^{\circ}$ to $1700^{\circ} \mathrm{F}$.

The results of these surface area determinations indicate that at devolatilization temperatures greater than $1500^{\circ} \mathrm{F}$, the accessible surface area of the chars decreases. This structure change could contribute to the lower reactivity observed for the stabilized chars at $1700^{\circ} \mathrm{F}$.

Task IV. Process Research Unit Tests

The goal of this task was to design, construct, and operate an adlabatic 11.5-inch-ID steam-oxygen-blown fluidized-bed gasifier as a PRU. The design of the PRU major vessels and other system components was based on the results of the first three program tasks. The unit was designed to operate up to $1800^{\circ} \mathrm{F}$ and $500 \mathrm{psig}$ with a maximum capacity of $1000 \mathrm{lb} / \mathrm{h}$ of biomass. The procurement activities for the construction of the PRU began after DOE author1zation was recelved on December 31, 1981. The major PRU vessels were delivered on-site at the end of June 1982. Other auxiliary equipment was delivered by August 1982. 
Construction of the PRU system was completed at the beginning of March 1983, 8 months after delivery of the major system vessels. Shakedown of individual units of the PRU system such as the feed preparation system and the live-bottom feed hopper, and lockhopper slide-gate valve system was done by January 1983. Shakedown of the integrated PRU system began in March 1983.

Description of the Process Research Unit

IGT built the PRU, at IGT's Energy Development Center (EDC) in Chicago. The PRU gasifier capacity is a nominal 12-TPD biomass feed. Figure 32 shows the isometric layout of the PRU equipment as installed in an existing structure, extending over 50 feet in total height. The 11.5-inch-ID, Incoloy $800 \mathrm{H}$ balanced pressure reactor 11 ner is surrounded by about 12 inches of fiber insulation in a 3-feet-OD X 24 feet carbon-steel pressure vessel. The 12 inches of bulk fiber insulation in the annular region is sufficient to assure a close approach to adiabatic gasification conditions. The pressure vessel is equipped with two horizontal 6-inch pipe nozzle positions (displaced by 2 feet) for introducing the feed biomass, at a point in the fluidized bed near the oxygen distributor. The gasifier is specifically designed to permit operational flexibility to study the effect of different bed heights and fluidizing-gas distributor positions relative to the feeding location. The total internal height of the gasifier is about 21 feet, with 10 feet for the reaction zone at the bottom and 11 feet for an enlarged 18-inch-diameter solids disengaging zone. The gasifier bottom closure flange has provisions for introducing the fluidization and gasification medium (steam and oxygen or air), a support member for thermocouples and fluldized-bed differential pressure probes and a solids drain. Two fluidizing-gas distributors are provided. One distributor is exclusively for fluidization control below the feed point and is positioned under the steam-oxygen or air distributor. This prevents the formation of a zone of stationary solids near the oxidizing gas distributor, which reduces the exposure of bed solids to possible high temperatures or sintering conditions.

In the PRU system the feed hopper and the assoclated solids handling equipment are designed for continuous feeding to the pressurized fluidized-bed gasifier. At the top of the continuously pressurlzed metering feed hopper is a 24-inch-ID by 6-feet-high lockhopper vessel, equipped with quick-openingand-closing gate valves, with provision for cyclic pressurization and 


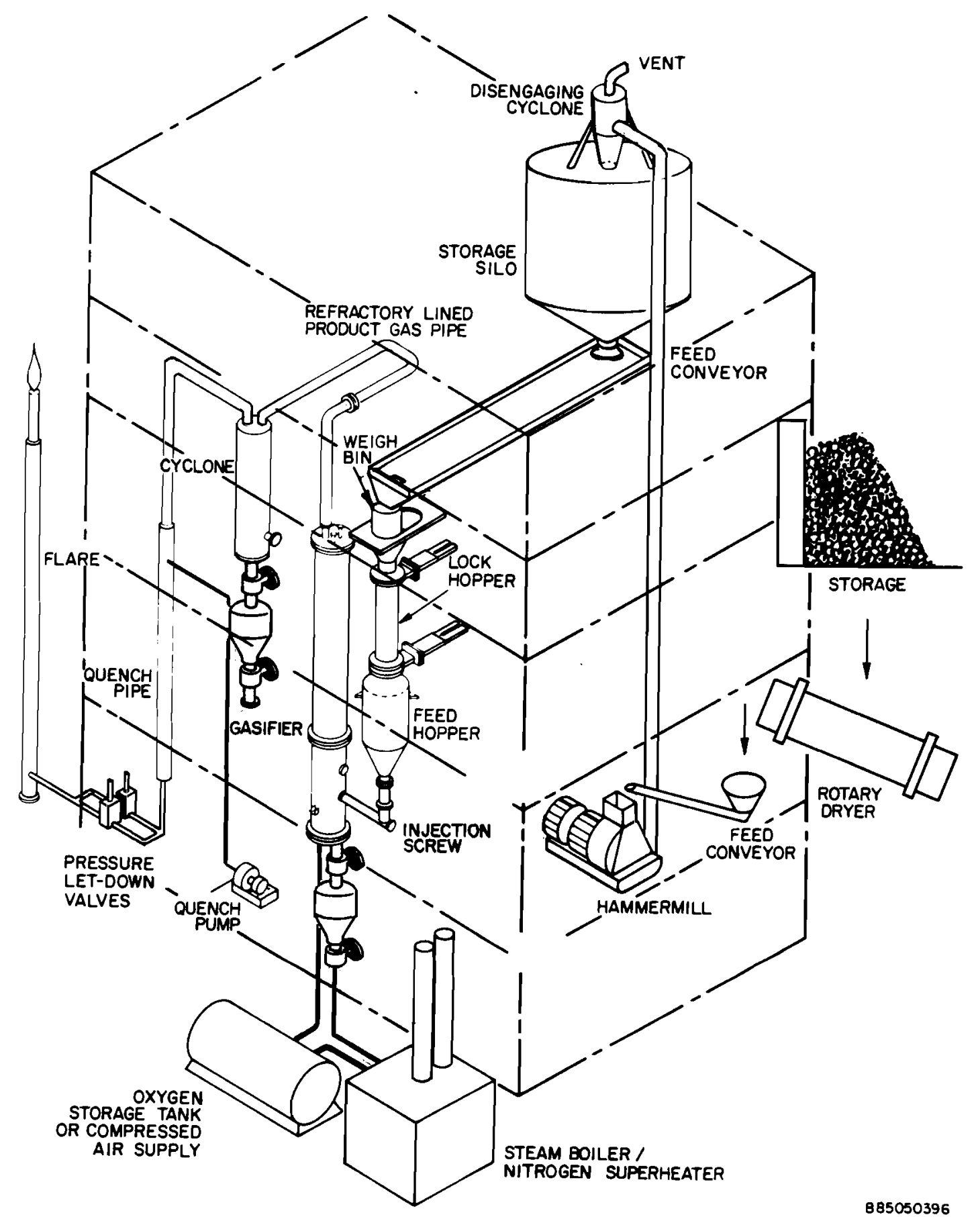

Figure 32. ISOMETRIC VIEW OF PRU EQUIPMENT LAYOUT 
depressurization with nitrogen. The opening diameters of the top and bottom gate valves for the tapered lockhopper vessel are 18 Inches and 24 Inches, respectively. The metering feed hopper is 4 feet in diameter, 9 feet high, and equipped with a multiple-screw live bottom, which meters and discharges the biomass material into the gasifier injector screw feeder. The entire feed system is designed for operating pressures up to $500 \mathrm{psig}$ and it is capable of continuously feeding $1500 \mathrm{lb} / \mathrm{h}$ of single screened biomass, with a top size of up to 1.5 inch. Some mechanical design drawings of the PRU are presented in Appendix A.

The piplng between the gasifier and the cyclone and between the cyclone and the downstream water spray quench is fabricated from refractory-lined carbon-steel. Partial quenching of the hot product gases after the cyclone to about $800^{\circ} \mathrm{F}$ avolds liquid condensation, and also permits the use of less expensive unlined carbon-steel pipe to direct the product gases to a metering station and pressure letdown system, before the gases are flared for disposal. The PRU also contains a lockhopper system to load the inert fluidization media Intially to the gasifier and on an "as required" basis. More detalls about the PRU instrumentation and experimental procedures are presented in Appendices $B$ and $C$, respectively.

\section{Shakedown Testing}

The shakedown of the entire PRU system began in March 1983 with a fourstep plan of tests. These steps included cold nitrogen pressurization tests; hot nitrogen $\left(700^{\circ} \mathrm{F}\right)$ pressure and flow tests; an extended hot nitrogen $\left(1100^{\circ} \mathrm{F}\right)$ flow test to dry the refractory linings and begin refractory curing; and a procedure test to heat the gasifier with charcoal and oxygen to $1500^{\circ} \mathrm{F}$ at 50 psig PRU system pressure.

This series of shakedown tests was successful. Minor leaks and instrumentation problems were corrected during the tests. The gasifier heat-up procedure established that a controlled startup would take about 8 hours. Additional corrections and recalibrations to various valves and instruments were completed after the tests.

During the heat-up test to reaction temperatures, charcoal was combusted with oxygen in the fluidized bed with sand. The gasifier temperature was held at $1500^{\circ} \mathrm{F}$ until the downstream piping temperatures exceeded $500^{\circ} \mathrm{F}$, to prevent 
downstream condensation of steam or blomass liquids. Hardwood charcoal was first used, but later coconut shell charcoal was ideal for the fluidized-bed combustion to bring the gasifier to operating temperature. Charcoal has a minimum of volatile material, which would condense on the colder downstream system. After the PRU system temperatures stabilized, the hot nitrogen and oxygen fluidizing gas was replaced with steam and oxygen, and dried pine wood was fed at a rate of about $100 \mathrm{lb} / \mathrm{h}$ for 2 hours at $1540^{\circ} \mathrm{F}$ and $61 \mathrm{psig}$. The transition to wood and steam was very smooth. Several samples of product gas were collected and the product gases were successfully flared.

Overall system operation was successful at 61-psig pressure. Analysis of the product gas by mass spectroscopy showed a typically expected mix of hydrogen, carbon monoxide, methane, carbon dioxide, and some $\mathrm{C}_{2}+$ gases. On a nitrogen-free basis the Btu content was about $300 \mathrm{Btu} / \mathrm{ft}^{3}$. No material balances were attempted in these shakedown tests. The adiabatic operation of the well-insulated gasifier was confirmed as the metal skin temperature of the pressure vessel was only a few degrees above ambient temperature.

Following this a program of system-proving tests was initiated to achieve operation of the PRU system at design conditions of temperature, pressure, and feed rates, and also to develop procedures to attain satisfactory material and energy balances.

\section{PRU System Proving Tests}

During a system pressurization test at 330 psig, a flange leak at the 24-inch slide-gate valve on the lockhopper vessel was found. Routine flange tightening procedure was followed, but the leak persisted and the opening and closing motion of the slide-gate became erratic with binding. Inspection after depressurization showed that the internal clearances within the slidegate retracting passage area were insufficient. The cause of the gate pinching and scoring was due to nonparallel cavity construction and raised weld beads that were not ground flush by the valve manufacturer.

The 4000-pound, 24-inch valve was removed from the PRU structure and shipped back to the manufacturer in Portland, Oregon. The defects in construction were repaired and the deeply scored knife gate faces were refinished. The 24-inch slide-gate valve was received from the manufacturer in the last week of April 1983 and reinstalled in the structure. To maintain 
the slide-gate clearances in the cavity and proper position during operation, seven hard plastic Rulon buttons of various thicknesses were installed to hold the gate in proper alignment to seal the 600-pound slide-gate in its closed position at IGT.

However, In the subsequent 300-psig pressure test the rear or lagging area of the gate would nọt seal properly with the existing adjustments. Therefore, two high-pressure, low-profile hydraulic jack cylinders were purchased and Installed Inside the valve's bonnet to push the gate up after its closing stroke. This modification achieved the approximate $0.020-1$ nch upward movement necessary to seal the gate at 300 psig.

In May 1983, the first test (WG-1) was made with gasifier operating conditions at about $1440^{\circ} \mathrm{F}, 200 \mathrm{psig}$, and $200 \mathrm{lb} / \mathrm{h}$ of $9 \%$-molsture maple hardwood. Start-up was smooth and wood charcoal was burned with oxygen with nitrogen as a moderator and fluidizing gas to heat the gasifier and downstream sections to operating temperatures. The charcoal was ignited at a temperature of $550^{\circ} \mathrm{F}$ instead of the $700^{\circ} \mathrm{F}$ as in the shakedown operations.

Just prior to achleving steady test temperatures with charcoal combustion and nitrogen fluidization medium in this test, a fallure with a lubrication pump for the high-pressure liquid nitrogen pump forced an earller-than-planned switchover to steam to malntain fluldization of the bed. The liquid nitrogen supply vendor replaced the pump after the run.

The switchover to steam for fluldization upon the loss of nitrogen, was done rapidly and the run proceeded with wood feeding and gasification. However, the fluidized-bed differential pressure sensing probes, which lost their high-pressure nitrogen purges during the abrupt transition to steam, plugged for the duration of the test, hence the state of the fluldized bed was unknown.

The test had lasted a 11ttle more than an hour when the bed temperature between the top and bottom reglons began to increase and diverge from their normally observed $\pm 20^{\circ} \mathrm{F}$ tight band. Temperature control of the bed could not be maintained and the test was terminated. Inspection of the bed silica sand material after draining the gasifier through the bottom 3-1nch nozzle showed some sintered sand material in the form of very porous friable clumps. 
It is possible that the sand bed defluidized for a short period during the emergency switchover to steam and caused a temperature excursion in a near-stagnant bed. After fluidization with steam was established the sintered lumps that formed interfered with fluidization and proper bed mixing.

Also, during this first system test, the 18-inch slide-gate valve began malfunctioning in a similar drag-grab manner that indicated clearance-stroking problems. After the test, the 18-inch valve was removed from the lockhopper and disassembled on-site. Repairs similar to what was done to the 24-inch valve were made by IGT personnel.

The gate cavity clearance, as manufactured, for the 18-inch gate was too tight and the weld fillets in the area were not ground smooth. This time a sheet of 1/8-inch Rulon hard plastic was installed under the gate to maintain gate position rather than plastic buttons as was done in the 24-inch valve. The gate-supporting rails were refurbished and aligned and the valve stroked smoothly and sealed properly.

After the delay caused by the 18-inch valve repair, the PRU system was readied for another test (WG-2). Gasifier operating conditions of $1430^{\circ} \mathrm{F}$, $210 \mathrm{psig}$, and $270 \mathrm{lb} / \mathrm{h}$ of maple hardwood were achieved and maintained for about 2 hours. All system components operated well in this test and operational control procedures were learned for the stable, smooth operation of the fluidized-bed gasifier.

The next shakedown test (WG-3) at 300 psig was made in June 1983 with the goal of achieving a $500 \mathrm{lb} / \mathrm{h}$ feed rate. After the gasifier heat-up period and after an hour into the approach to steady state at the first feed rate plateau of $270 \mathrm{lb} / \mathrm{h}$, the feed injector screw to the gasifier began binding. This caused the screw drive motor to overload and trip the circult breaker repeatedly. Consequently, steady-state conditions could not be achieved. The test was stopped to correct the injector screw operation. The cause of the screw binding was found to be a misalignment of the shaft-bearing with the screw-housing, which was corrected by slightly enlarging two of the flange bolt holes to accept pressed-fit body bolts to act as fixed alignment dowels to ensure proper flange mating and alignment after repeated post-test ins pections. 
All of the other mechanical equipment in the system worked well. The slide-gate valves operated smoothly and the lockhopper feed system cycle time was satisfactory for 6 to 7 cycles/h, which is sufficient to achieve feed rates about $1000 \mathrm{lb} / \mathrm{h}$.

During the pause in the DOE/PNL sponsored program following Test WG-3, pressurized (up to $500 \mathrm{psig}$ ) low-Btu gasification tests were conducted for a private sponsor in a 6-inch-ID fluidized-bed gasification system. Following the useful experience of this biomass test program, the DOE/PNL program was resumed to complete the remaining higher feed rate shakedown tests. It was learned that when silica sand is used as inert solids, there is a risk of forming clinkers during gasification at bed temperature between $1500^{\circ}$ and $1600^{\circ} \mathrm{F}$. Consequently, it was decided to use some form of alumina as the inert solids medium.

In February 1984, two more system proving tests (WG-4 and WG-5) at 300 psig and $1500^{\circ} \mathrm{F}$ were made to prove the PRU system at high feed rates of 500 and $1000 \mathrm{lb} / \mathrm{h}$. Alumina grit (No. $80 \mathrm{grit}$ ) was used as the inert solids in these tests.

The conditions of Test WG-4 held steady in the gasifier at the $500 \mathrm{lb} / \mathrm{h}$ feed rate for a half hour unt1l the automatic water quench flow became erratic. The water-spray quench controls the downstream gas temperatures from the exit of the refractory-lined pipe to the entrance to the uninsulated carbon steel piping to the flare. Because the gas temperatures were exceeding $800^{\circ} \mathrm{F}$ in the carbon steel plpe, the test was stopped. The total gasification time logged was about $2-1 / 2$ hours including the stepwise climb in feed rates at 200 and $3751 \mathrm{~b} / \mathrm{h}$.

The cause of the erratic quench flow was found after the test to be simply dislodged rust scale that plugged the 1/16-inch-diameter orifice in the spray nozzle. The lines were cleaned and a strainer was installed in the line.

The PRU system was prepared for Test WG-5, conducted at conditions of $.1500^{\circ} \mathrm{F}, 303 \mathrm{psig}$, and a set feed rate of $1000 \mathrm{lb} / \mathrm{h}$. The duration of the time at this setting was about $1-1 / 2$ hours (96 minutes) following perlods of 1 hour each at 250 and $500 \mathrm{lb} / \mathrm{h}$ feed rates. The test was stopped after 96 minutes 
because the high-pressure liquid oxygen pump was unable to be restarted at the oxygen storage and compression pad at EDC. The vendor repaired the pump after the test.

Samples from this test of the bed material, the solids receiver solids, and condensate collected from a raw gas slipstream were sent for analysis. The on-line gas chromatograph measured steady wet-gas compositions, which calculated to be about $350 \mathrm{Btu} / \mathrm{SCF}$ on a dry, nitrogen-free basis. The collected liquid sample appeared to be quite clear with some fine carbon black material and some naphthalene.

The wood metering screw feed rate calibration that was originally done at ambient conditions by collecting weighed quantities in a drum appeared to be about $12 \%$ higher in the last test than what was fed over the test period according to the weigh bin load cell recordings. The load cell weights over the test period indicated a wood feed rate of $853 \mathrm{lb} / \mathrm{h}$ as timed between occurrences of the "empty" condition light from the level sensor in the livebottom feed hopper.

According to the mid- and three-quarter position settings on the feeder system controls, the PRU system is capable of feeding and gasifying at higher rates. During Test WG-5, the lockhopper loading, pressurization, and depressurization cycle was consistently done within 4 minutes which, if continued automatically, would feed $1900 \mathrm{lb} / \mathrm{h}$. The feed system was calibrated earlier to $1600 \mathrm{lb} / \mathrm{h}$ of $10 \%$ moisture wood chips.

Tests WG-4 and WG-5 confirmed that the PRU system was capable of operating at the design conditions. Even though the system was able to feed and gasify in excess of $1000 \mathrm{lb} / \mathrm{h}$ of biomass at $1800^{\circ} \mathrm{F}$ and $500 \mathrm{psig}$, the "centerline" or baseline operating conditions for the parametric testing were selected to be at 750 to $800 \mathrm{1b} / \mathrm{h}$ of biomass at $1500^{\circ} \mathrm{F}$ and $300 \mathrm{psig}$. The performance trends that were found as a function of primary operating variables identified approaches for system optimization and indicated the need or extent of various upstream or downstream operations for scaled-up processes. The program test matrix covered a range of temperatures and feed rates that were distributed around the centerline conditions in order to determine the effect of operating variables, turndown limiting throughput capabilities, and feeds tock types. 
The results for Test WG-5 in Table 14 show that the specific feed throughput rate is about $1200 \mathrm{lb} / \mathrm{ft}^{2}-\mathrm{h}$ and the specific heat release amounts to $8.5 \times 10^{6} \mathrm{Btu} / \mathrm{ft}^{2}-\mathrm{h}$. A review of the system proving test results in this table show a learning and steady improvement in the PRU operating capabilities in terms of increasing temperatures, pressures, feed rates, reduction in steam and oxygen requirements, and an increase in carbon conversion.

\section{Parameter-Variation Tests}

IGT began the gasification parameter variation tests with the PRU in March 1984. The PRU tests were conducted at different gasification conditions to develop process optimization information on fluidized-bed gasification of biomass to produce medium-Btu value gas. A total of 22 tests have been conducted in the program. Fourteen of these tests were operated for steadystate data collection periods of approximately 4 hours, sufficient for parameter evaluation, while five tests were conducted for longer duration steady-state periods of up to 3 days. Three tests consisted of less than 4 hours steady-state operation.

These tests produced adiabatic, process-design data on the effect of temperature, steam feed rate, pressure, biomass throughput rate, type of feedstock, fluidized-bed height, and feed moisture content on pressurized oxygen-blown, fluidized-bed gasifier performance. The tests were conducted over the parameter range of $1390^{\circ}$ to $1800^{\circ} \mathrm{F}$ temperatures, 69 to $330 \mathrm{psig}$ pressures, and feed rates up to $1030 \mathrm{lb} / \mathrm{h}$. The steam input rates varied from 0.41 to $1.18 \mathrm{lb} / 1 \mathrm{~b}$ wood feed with the wood feed moisture content at approximately $10 \%$. Different tests were made with feed moisture contents from $5 \%$ to $27 \%$ by weight.

The following is a short summary of the tests conducted in the 11.5-inch I.D. PRU that highlights specific test purposes and describes system modifications and/or repairs. Table 15 presents all of the test conditions and analyzed test results. Gasification trends and the effects of the test parameters are discussed later.

Test GT-1. The first test of the PRU test parameter variation matrix was designed to investigate the effect of temperature on pressurized oxygen blown biomass gasification. Test GT-1 was conducted on March 21, 1984 at a temperature of $1500^{\circ} \mathrm{F}$ using No. 80 alumina grit as the inert solids in the fluidized bed. 
Table 14. SUMMARY OF SYSTEM PROVING TEST RESULTS

\begin{tabular}{|c|c|c|c|c|c|}
\hline Test No. & WG-1 & WG-2 & WG-3 & WG-4 & WG-5 \\
\hline Pressure, psia & 218 & 225 & $159-285$ & 315 & 318 \\
\hline Temperature, ${ }^{\circ} \mathrm{F}$ & 1444 & 1432 & 1368 & 1515 & 1510 \\
\hline Feed Rate, Ib/h & 200 & 270 & 270 & 461 & 853 \\
\hline Steam, $1 b / 1 b$ feed & 3.4 & 2.1 & 2.6 & 1.4 & 0.92 \\
\hline Oxygen, $1 b / 1 b$ feed & 0.58 & 0.29 & 0.44 & 0.4 & 0.3 \\
\hline $\begin{array}{l}\text { Product Gas Rate (dry), } \\
\text { SCF } / \mathrm{h}\end{array}$ & 5493 & 7668 & 10,755 & 15,042 & 20,065 \\
\hline \multicolumn{6}{|l|}{$\begin{array}{l}\text { Product Gas Composition } \\
(\text { dry }) \text {, mol \% }\end{array}$} \\
\hline $\mathrm{H}_{2}$ & 6.2 & 13.0 & 15.9 & 14.9 & 21.8 \\
\hline $\mathrm{CO}$ & 2.9 & 9.9 & 8.7 & 7.9 & 10.9 \\
\hline $\mathrm{CO}_{2}$ & 5.2 & 19.3 & 26.9 & 24.9 & 29.4 \\
\hline $\mathrm{CH}_{4}$ & 3.0 & 8.8 & 7.5 & 8.5 & 13.2 \\
\hline $\mathrm{C}_{2} \mathrm{H}_{6}$ & 0.3 & 0.8 & - & - & 0.4 \\
\hline $\mathrm{C}_{2} \mathrm{H}_{4}$ & 0.2 & 0.3 & - & -- & 0.1 \\
\hline $\mathrm{C}_{6}+$ & - & 0.2 & - & -- & 0.5 \\
\hline $\mathbf{N}_{2}$ & 82.2 & 47.7 & 41.0 & 43.8 & 23.7 \\
\hline Total & 100.0 & 100.0 & 100.0 & 100.0 & 100.0 \\
\hline $\begin{array}{l}\text { Dry, } \mathrm{N}_{2} \text {-free Gas, } \\
\quad \text { SCF/Ib feed }\end{array}$ & 4.9 & 14.9 & 23.5 & 18.3 & 17.9 \\
\hline $\begin{array}{c}\text { GHV, dry } \mathrm{N}_{2}-\mathrm{free} \\
\text { Gas, Btu/SCF }\end{array}$ & 384 & 363 & 264 & 284 & 349 \\
\hline
\end{tabular}




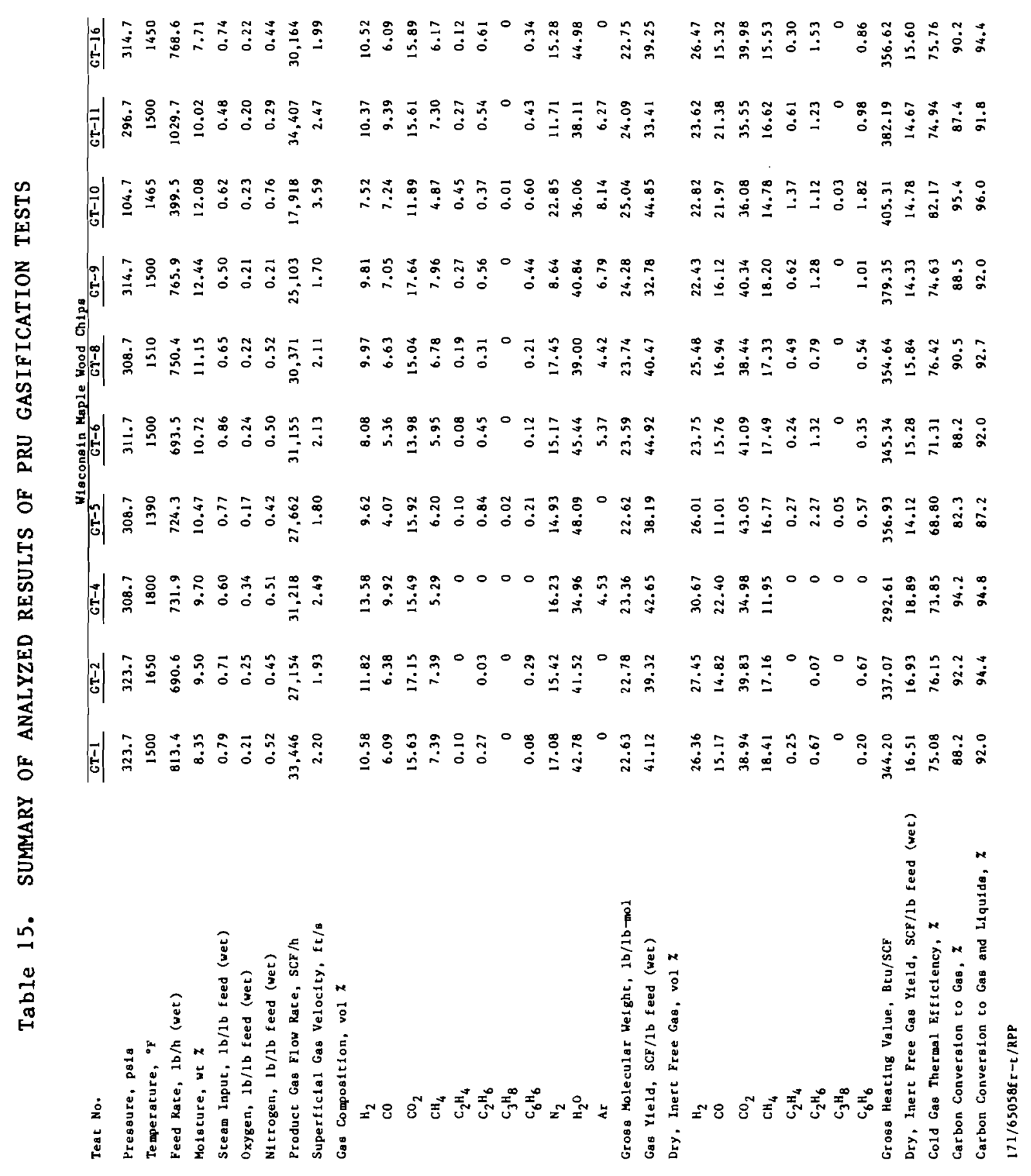




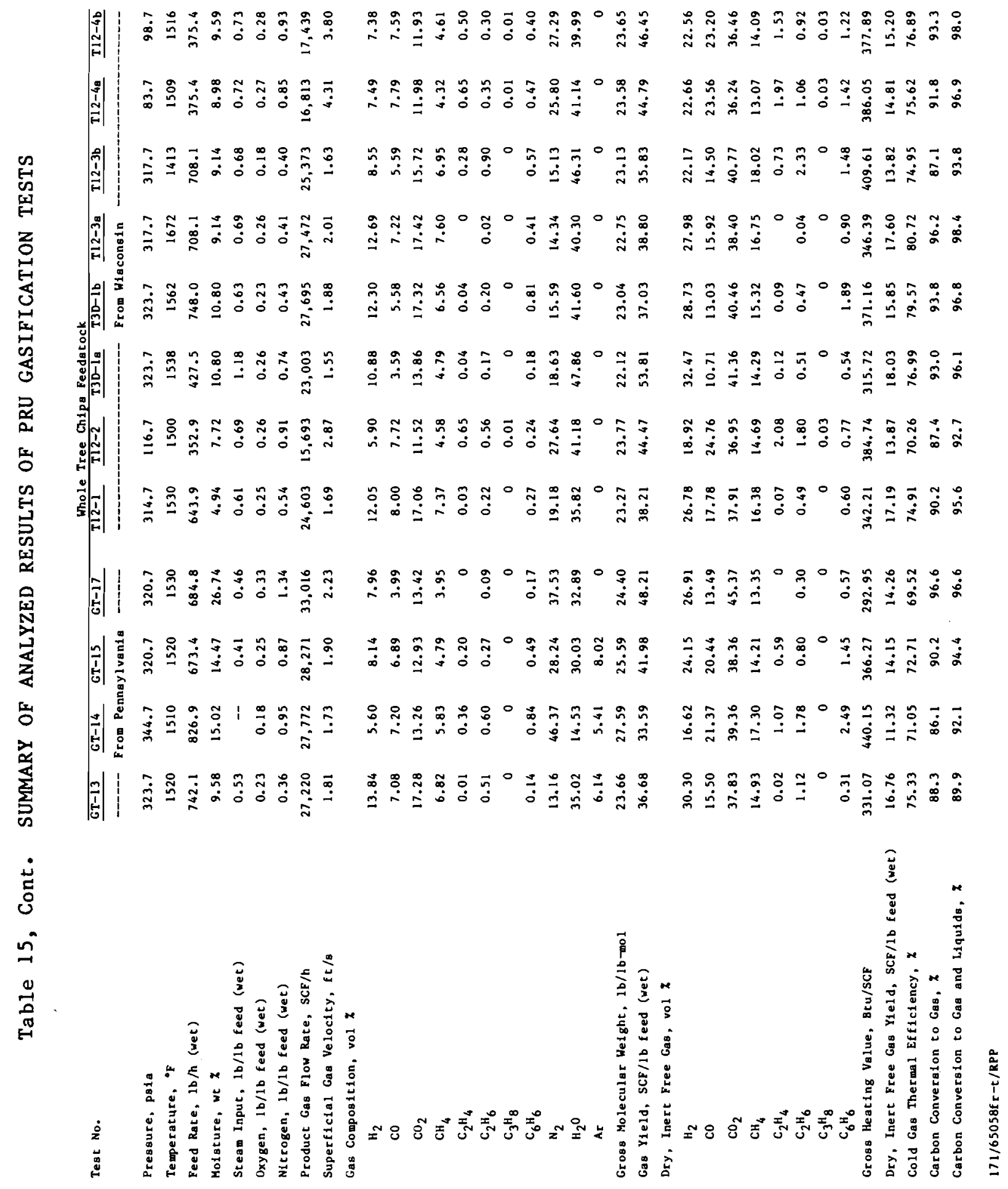


Test GT-1 was successfully completed with a 4-hour steady-state period at a feed rate of $813.4 \mathrm{lb} / \mathrm{h}$. The heat up and pressurization period went smoothly into the gasification period. Successive 1-hour steps at about 250 and $500 \mathrm{lb} / \mathrm{h}$ feed-rates preceded the target feed rate. The test was voluntarily terminated at the end of the 4-hour period. Post run inspection of the unit showed that a significant amount of the Inert alumina grit solids were carried overhead to the solids receiver vessel.

Because the carryover was a significant portion of the inert material in the bed, the alumina grit was replaced with slightly larger, but spherical alumina beads for Test GT-2 and used in the remainder of the tests in the program. The properties of the alumina grit and alumina beads are given in Table 16. Using these properties and the following correlation for the minimum fluidization velocity developed at IGT, the minimum fluidization velocity was calculated.

$$
u_{\mathrm{mf}}=\left(\mu / \rho_{g} D_{p}\right)\left\{\left[(25.25)^{2}+0.0651 \mathrm{Ar}\right]^{1 / 2}-25.25\right\}
$$

where -

Ar $=$ Archimedes Number

$$
=D_{p}^{3} \rho_{g}\left(\rho_{p}-\rho_{g}\right) \cdot g / \mu^{2}
$$

The fluidizing-gas properties used in the calculation were for steam at $1000^{\circ} \mathrm{F}$ and 300 psig.

Test GT-2. The second test in this series on gasification temperature variation (GT-2) was conducted on April 11,1984 at $300 \mathrm{psig}$ and $1650^{\circ} \mathrm{F}$. Test GT-2 was successfully completed at a feed rate of about $7001 \mathrm{~b} / \mathrm{h}$. The heat up and pressurization period went smoothly into the gasification period, which also followed successive 1-hour steps at about 250 and $500 \mathrm{lb} / \mathrm{h}$ feed rates before reaching the target feed rate. After achieving a 4-hour steadystate period the test was voluntarily terminated.

Test GT-3. Gasification Test GT-3 was attempted on Apri1 25, 1984 at $300 \mathrm{psig}$ and $1400^{\circ} \mathrm{F}$. However, during the steady-state period the injector screw stopped, interrupting the wood feed to the gasifier. The test was terminated to fix the injection screw alignment.

Test GT-4. Another gasification test was conducted on May 24, 1984. Test conditions for this test (GT-4) were $1800^{\circ} \mathrm{F}$ bed temperature at 300 psig 
Table 16. PROPERTIES OF GASIFIER INERT SOLIDS

\begin{tabular}{|c|c|c|}
\hline & $\begin{array}{l}\text { Alumina Grit } \\
\text { (No. } 80 \text { grit) } \\
\end{array}$ & $\begin{array}{l}\text { Alumina Beads } \\
(40 \times 70 \text { mesh }) \\
\end{array}$ \\
\hline IGT Sample No. & 48925 & 48926 \\
\hline U.S. Sieve & $--\infty-\infty$ wt & $-\infty-\infty-\infty$ \\
\hline 40 & 0.0 & 0.3 \\
\hline 45 & 0.0 & 54.4 \\
\hline 50 & 0.0 & 37.1 \\
\hline 60 & 0.1 & 7.8 \\
\hline 70 & 13.7 & 0.3 \\
\hline 80 & 53.1 & 0.1 \\
\hline 100 & 29.8 & 0.0 \\
\hline 120 & 3.1 & 0.0 \\
\hline 140 & 0.1 & 0.0 \\
\hline 170 & 0.1 & 0.0 \\
\hline Pan & 0.0 & 0.0 \\
\hline Total & 100.0 & 100.0 \\
\hline Bulk Density, lb/CF & 125.3 & 138.6 \\
\hline Particle Density, $1 \mathrm{~b} / \mathrm{CF}$ & 306.0 & 223.0 \\
\hline $\begin{array}{l}\text { Calculated Minimum } \\
\text { Fluidization Velocity, } \mathrm{ft} / \mathrm{s} \\
\text { for Fluidization Medium of } \\
\text { (Steam at } 1000^{\circ} \mathrm{F}, 300 \mathrm{psi} \text { ) }\end{array}$ & 0.2 & 0.38 \\
\hline
\end{tabular}

Alumina Grit

(No. 80 grit)

48925

IGT Sample No.

U.S. Sieve

40

45

80

100

120

140

170

Pan

Total

Bulk Density, Ib/CF

Particle Density, 1b/CF

$171 / 65058 f r-t / R P P$

Alumina Beads

48926 
with about $700 \mathrm{lb} / \mathrm{h}$ feed rate. An inert tracer gas injection system was installed for perlodic checking of the product gas flow measurements. Argon was chosen as the inert gas. The argon input flow rate was regulated to result in a $5 \%$ concentration in the raw gas downstream from the gasifier. A 5\% argon concentration was able to override the low background argon (about $0.1 \%$ ) normally contalned in the feed oxygen. The argon was metered for a 1-hour period during the steady gasification pertod at the feed injection screw's nitrogen purge position. The nitrogen purge was shut off during this period so as to not inject an additional amount of cold gas into the gasifier. The feed hopper purge nitrogen, however, was always maintained.

Test GT-5. On June 13, 1984 Test GT-5 was conducted with nominal test conditions of $1390^{\circ} \mathrm{F}, 300 \mathrm{psig}$, and at a wood feed rate of about $720 \mathrm{lb} / \mathrm{h}$. An improved sampling system was installed prior to Test GT-5 to obtain a large isokinetic raw-gas sample for measuring solids carryover and liquids production rates. The sampling system was designed to operate for 1 hour during the steady 4-hour period and to withdraw a sample at a rate of approximately $1 \%$ of the total flow from the gasifier. The solids are first removed with a hot sintered metal filter, then the stream is cooled and the liquids are condensed first in a water-cooled condenser then by an ice bath-trap condenser. The condensate-free raw gas is then metered and vented. The collection of a large volume of condensate provided a representative sample that contributed to better off-line chemical analysis and consequently to improved elemental and material balances. The measured steam condensate rate also obtained was useful in validating the undecomposed steam concentration in the raw gas as determined by the on-line wet-gas chromatograph. A more detailed description of this isokinetic sampling system is presented in Appendix D.

Test GT-6. Test GT-6 was conducted on June $28 \mathrm{th}$ at $1500^{\circ} \mathrm{F}, 300 \mathrm{ps} 1 \mathrm{~g}$, and about $700 \mathrm{lb} / \mathrm{h}$ feed rate.

During the 4-hour steady-state operation period in Test GT-6, the heatsensitive vessel paint showed an isolated hot spot, of about a 12-inch diameter near the top of the gasifier pressure vessel. The skin temperature in this spot ranged from $250^{\circ}$ to $500^{\circ} \mathrm{F}$. To complete the 4-hour steady-state operation and collect the required data, the hot spot was controlled with water cooling. 
To correct this insulation breach between the liner and pressure vessel the reactor top head was removed for inspection as part of the post run activities of Test GT-6. The top 4 feet of the bulk fiber insulation in the annular region of the pressure vessel, enclosing the hot spot, was removed and repacked. The numerous pressurizations and depressurizations over the previous tests could have caused a slumping of the insulation.

Test GT-7. After the insulation was repacked, gasification Test GT-7 was conducted on July 20,1984 . The nominal test conditions were $1500^{\circ} \mathrm{F}$, $300 \mathrm{psig}$, and $700 \mathrm{1b} / \mathrm{h}$ of maple wood feed. The purpose of this test was to reduce the s.team-to-wood ratio to about 0.6 as part of the overall test plan. During the steady-state operation, the steam boller went off-line when the feedwater control on the boller malfunctioned and interrupted the flow of makeup water to the boller. Even though the boller was brought back on-line within minutes, the fluidizing-gas distributor ring, with flow interrupted, became plugged with the fluidized-bed inert solids. Consequently, it was impossible to resume fluidization, and the test was terminated.

During this test, different hot spot regions, about 5 feet from the top, appeared at a lower elevation opposite to the first hot spot area. The shell temperature was again controlled by a small water spray to complete the test, but to correct the problem for continued testing, the annular insulation region was emptied and repacked uniformly down to about 6 feet from the gasifier top.

Test GT-8. After a general check-out of the PRU, gasification Test GT-8 was conducted on August 2, 1984. Nominal test conditions were $1500^{\circ} \mathrm{F}$, $300 \mathrm{psig}$, and $750 \mathrm{lb} / \mathrm{h}$ of maple hardwood feed. The purpose of this test, similar to that of the aborted test, GT-7, was to reduce the steam-to-wood ratio to complement the previous steam-to-wood ratio tests. The heat-up and pressurization period went smoothly into the gasification period, which followed a stepwise wood feed rate of about $300 \mathrm{lb} / \mathrm{h}$ before reaching the target feed rate of about $750 \mathrm{lb} / \mathrm{h}$. The test was voluntarily terminated at the end of a 2.5-hour steady-state period when the feed supply was depleted from the 20-ton overhead storage silo.

During this test the gasifier shell hot spots described earlier appeared again, Indicating that a persistent flow of product gas was bypassing through the insulation area. After the run, the gasifier top head was removed and the 
insulation in the annular area was removed and inspected. It was eventually repacked to a depth of 12 feet from the top. (The overall length of the upper gasiffer shell is 16 feet.)

However, upon further examination, by separating the upper and lower reactor vessel sections, it was found that part of the product gas was bypassing from the slip-joint area between the two reactor sections. This was caused by a fallure in a seal weld of the semitorroidal bellows that isolate the Insulation section from the fluidization zone and also isolate the lower and upper sections of the reactor vessel. The bellows had flexed and the weld to the reactor liner gave way. The gasifier construction drawings for the balanced pressure liner is shown in Appendix A.

The procedure selected for repairing the upper bellows involved concentrically cutting the bellows about 4 inches away from the 11.75-inch-OD liner and inserting a short, space-filling cylinder and disc set about the liner as a transition plece between the bellows and liner, providing an accessible welding area. The welding of the thin-gauge semitorroidal bellows to the installed transition repair piece was done by using an inert gasmultiple-pass arc welding technique.

During the time of this repair procedure, a new outlet pipe flange set was installed in the 8-1nch-ID refractory-lined product-gas pipe, as part of the same welding job order. With this extra flange in place, only a short length of product-gas pipe has to be removed to permit easy access to the top of the reactor for maintenance and inspection. New instruments were also added to prevent Inadvertent overpressurization of each of the annular insulation areas with respect to the liner.

Also, In July 1984, a new component was added to the PRU system to improve the method of loading the inert fluidized-bed solids into the gasifier. A lockhopper system was fabricated with components on-site at IGT. This vessel is now charged with inert solids for the test and pressurized to the system pressure. The solids are discharged from the vessel through one of the unused sight-port nozzles installed on the feed hopper. The solids flow directly down the wood chute to the injection screw without contacting the metering screws. This system simplified the loading procedure, which previously had required the opening, closing, and sealing of the 24-bolt, 24-1nch manway on the feed hopper. 
Test GT-9. The conditions for Test GT-9, conducted on October 11, 1984, were $1500^{\circ} \mathrm{F}$ and $300 \mathrm{psig}$ with a feed rate of $7651 \mathrm{~b} / \mathrm{h}$. The test achieved a low steam-feed rate of $0.5 \mathrm{lb}$ steam/1b feed. The operation of Test GT-9 also confirmed the successful repair of the bellows seal arrangement for 1solation of the two bulk fiber insulation zones from the gasification zone. The gasifier pressure vessel skin temperatures remained at about $110^{\circ} \mathrm{F}$ during the test, with no hot spots appearing on the top section of the gasifier. The start-up procedure was also modified to protect the bellows 1solation seal by slowly pressurizing the PRU before beginning the heat-up.

Test GT-10. Test GT-10 was operated at a gasifier bed temperature of $1465^{\circ} \mathrm{F}$ and a system pressure of 100 psig to investigate the effect of lower system pressure on gasifier performance. The feed rate of maple wood was reduced to $400 \mathrm{lb} / \mathrm{h}$ to maintain the correct superficial gas velocity.

Test GT-11. After the system turnaround period, Test GT-11 was conducted on November 8, 1984. Conditions for this test were a gasifier bed temperature of $1500^{\circ} \mathrm{F}$ and a gasifier bed pressure of 300 psig. Test GT-11 achieved the highest wood feed rate of the program. The wood feed rate was increased in a stepwise fashion to about $1030 \mathrm{lb} / \mathrm{h}$. The test was conducted at this feed rate for a steady-state period of 4-1/2 hours, with a period of approximately $1 / 2$ hour of reduced feed rate when the supply of wood feed in the storage s1lo was depleted and additional wood chips had to be crushed to continue the test at the higher feed rate. No operational difficulties were encountered when the operation was resumed following the interruption in the wood feed rate. After a 4-hour steady-state period at a feed rate of $1030 \mathrm{lb} / \mathrm{h}$ was achieved, Test GT-11 was voluntarily terminated. Up to this point all tests were conducted with maple wood chips.

Test GT-12. Test GT-12 was the first gasification test conducted with Pennsylvania whole tree chips at a feed rate of $750 \mathrm{lb} / \mathrm{h}$ at $1500^{\circ} \mathrm{F}$ and 300 psig. The operation of the PRU system went smoothly with this material. The operation differed from that with the maple feedstock only in that the lower bulk density of the whole tree chips required a lower lockhopper-charge weight in the feeding cycle. The product gas composition indicated by the online gas chromatograph was similar to the past maple feedstock gasification tests. 
Test GT-12 had to be stopped after about 2-1/2 hours into the steady operating perlod when a 0.5-inch-OD tubing-to-pipe cap seal weld failed on the product gas particulate and condensate sampling probe. The leak opening was located upstream of the first shutoff valve and could not be isolated. A new sampling probe was constructed with thicker wall tubing to make heavier welds in the area, and it was installed for the next test.

Test GT-13. Test GT-13 was conducted on December 13, 1984. Conditions for this test were similar to those for the aborted Test GT-12. The gasifier was operated at $300 \mathrm{psig}$ and a bed temperature of $1520^{\circ} \mathrm{F}$ with a feed rate of $740 \mathrm{lb} / \mathrm{h}$ of whole tree chips. Test GT-13 was the first successful test using Pennsylvania whole tree chips as feed material. No operational difficulties were encountered during the approximately 4-hour steady-state period. After this period, the test was voluntarily terminated.

During the earlier system proving tests, a leak occurred in the slidegate valves of the lockhopper feeding system as was described previously. The early repairs or modifications were not completely successful as the leak at the 24-inch valve flange to the lockhopper flange persisted throughout the initial parametric variation testing. The leak, however, was measurable and the leaking gas was also feed hopper makeup nitrogen. The problem persisted because the slide-gate valve's flange thickness was designed by the valve manufacturer for 500 psig cold water pressure code. These flanges, therefore, were only about half the thickness required by the ASME-ANSI pressure code by which the PRU system was designed. This fact and the valve's horizontal installation position rather than the manufacturer's normal vertical installation positions contributed to a poor seal integrity in this new valve application. Thicker flanges and substantial slide-gate support provisions were necessary to improve the operational reliability of these valves. An improved valve design was made by Thomas R. Miles Design Consulting Engineers in Portland, Oregon. The original manufacturer did not indicate that they were willing to improve and build the new valves.

During January 1985, the improved-design 18- and 24-inch-diameter-opening replacement slide-gate valves for the feed system lockhopper were installed. The existing slide-gate valves from the Fabrivalve Co. were removed and stored aside. Physical modifications to the system were straightforward in fitting the valves in place and rearranging the electrical and pneumatic system components and interlocking safety functions. 
Many design features were incorporated on these valves to make field servicing simple. After installation, the valves were disassembled to install the ring-type seals of the slide-gate. This operation, with a practiced crew and with in-place hoisting could be completed in 1 day for both valves. This was a major improvement in comparison to the previous valves, which required over 1 week for a similar seal replacement operation.

In addition, the valves were test-cycled, before delivery to IGT, for 350 cycles. The original Fabrivalve Co. valves had to be repaired and modified after 50 cycles. After the last test in this program, the new valves had 1500 cycles of operation with no sealing difficulties.

A pressure test of the new valves and feed system indicated that no leaks were present at the gate seals or at the flange areas. The new valves operated satisfactorily during the remainder of the tests. The opening and closing strokes and the gate's "1ift-to-seal" mechanism operated silently and smoothly compared to the original valve's "bump-nose" lifting. This performance attests to the operational improvements provided by the substantial railsupport and alignment provisions for the sliding gate. The gate "Ifft-toseal" mechanism also prohibits rubbing wear on the elastomer seal ring, which was severely galled in the original valves. A mechantcal gate stroke counter was installed to monttor the performance of the valves.

Test GT-14. Test GT-14 was conducted on February 14, 1985 to Investigate gasifier operation without external steam addition other than that from the molsture content of the whole tree chip feed and the chemically produced water In the gasifler. Steam produced from the $15 \%$ moisture in the wood feed and from chemically produced water accounted for a steam-to-wood ratio of $0.23 \mathrm{lb} / 1 \mathrm{~b}$. For th1s test, the normally used steam was replaced with nitrogen to maintain a minimum fluidization velocity near the oxygen distributor and the feed location. The nitrogen was preheated to about $900^{\circ} \mathrm{F}$ before entering the gasifier distributor ring and nozzle. No operational difficulties were encountered using nitrogen gas as the fluidizing medium.

Test GT-15. Test GT-15 using the whole tree chips as feed material, was begun on February 28, 1985 and completed on March 1, 1985. For Test GT-15, the PRU steam flow-control system was modified to permit nitrogen to mix with steam at the entrance to the gasifier. This allowed a lower steam-to-wood ratio of $0.411 \mathrm{~b} / 1 \mathrm{~b}$. With the existing steam supply system it was not 
possible to superheat both nitrogen and steam; therefore, cold nitrogen was added to steam, reducing the incoming fluidizing-gas temperature to $640^{\circ} \mathrm{F}$ from the normal operating temperature of about $800^{\circ} \mathrm{F}$. Consequently, to obtain a gasifier bed temperature of $1500^{\circ} \mathrm{F}$, the oxygen flow was increased to compensate for the mixture of cooler incoming fluidizing steam and nitrogen. During Test GT-15, steady-state operation was maintained for a period of $3-1 / 2$ hours before the test was terminated due to a leak in the low-pressure piping downstream of the pressure letdown valves.

Test GT-16. Maple wood chips were used as feed materlal for Test GT-16 with the purpose to investigate the gasification process with a lower fluidized-bed height and compare to the previous tests. The gasifier was operated at $1450^{\circ} \mathrm{F}$ and $300 \mathrm{psig}$ with a wood feed rate of $770 \mathrm{lb} / \mathrm{h}$. The fluidized-bed height-to-diameter ratio (L/D) was between 3 and 4 compared with the previous maple wood feed tests with a ratio of about 6 . The wood feed and, consequently, the oxygen flow were interrupted in the middle of this test for a brief period in order to repair a bearing on the wood-feed drag conveyor supplying wood to the weigh bin. The gasifier continued to operate smoothly after this quick repair, and the test was voluntarily terminated after a cumulative steady-state operation of 4 hours.

Test GT-17. Test GT-17 was conducted on March 29, 1985 using 27\% molsture content whole tree chip feed material. Conditions for this test were $1530^{\circ} \mathrm{F}$ and $306 \mathrm{psig}$. Some conveying equipment difficulties were encountered In handling the higher moisture content feed, but these were overcome by reducing each charge of wood to the weigh bin. Longer sliver-type wood pieces present in the feed at this moisture level helped to lock together clumps of feed and restrict the flow.

After Test GT-17, work began on the modifications to the PRU equipment and piping for the extended duration gasification tests for up to 1 week. In preparation for the modifications to the PRU, certain equipment was cleared from the work area, pipe insulation was removed, and cuts were made in the product gas pipe sections.

An internal cyclone was fabricated and installed in the solids receiver vessel to continuously collect the carryover solids. A char collection lockhopper vessel was fabricated and installed under the solids recelver vessel to periodically discharge the collected char during the long-term 
gasification tests. Special high-temperature service ball valves were installed between the lockhopper and the cyclone. New control instrumentation with safety interlocks was installed in the control room for the lockhopper vesse1.

The 8-inch-OD product gas pipe was repacked with refractory at each new weld joint with cast, mitred joints to assure the thermal insulation integrity. A new thermocouple supporting lance for the fluidized-bed temperatures was made with the thermocouples now placed inside the lance to protect against long-term test erosion. The oxygen nozzle and steam distributing ring were raised about 18 inches to reduce the gasification zone under the feed location.

Explosion-proof motors for the hammermil1, pneumatic lift fan, and the feed drag conveyor were installed, which permitted simultaneous operation in the buflding during gasification tests. New feed level sensors that do not require periodic calibration were installed in the lockhopper and the 1ivebottom feed hopper. The new feed hopper level sensor was a vast improvement over the original sensor. It consisted of a vertical probe that continuously indicated the level in the hopper, rather than, as before, indicating just an empty condition.

Test T12-1. The first test of the long-term test series (T12-1) was completed on June 20, 1985. The test logged 10.5 hours of steady-state operation at $1530^{\circ} \mathrm{F}, 300 \mathrm{psig}$, and $640 \mathrm{lb} / \mathrm{h}$ feed rate. The, feed material for this test and the other long-term duration tests was whole tree chips obtained from Wisconsin instead of Pennsylvania. The new material fed well in general, except that a couple of hours elapsed before the feed rate stabilized at $640 \mathrm{lb} / \mathrm{h}$. The lower charging/feeding rate could have been due to the possibility of air-segregation of particles first loaded into the storage silo as they free-fell down about 30 feet from the top filling port of the silo.

During the test the cyclone operated satisfactorily at process temperature and pressure. The cyclone lockhopper discharge system worked well on a 1/2-hour emptying cycle. The discharged solids were blown Into a large existing vessel outside the PRU building. The flare plume was visually clean, free of the occasional puffs of dark dust that occurred before the cyclone was installed. 
The test was terminated after 10.5 hours of operation because of a rapid loss of fluldized-bed gasifler thermocouples. The test was terminated to avold the possibility of excessive temperatures occurring in the gasifier. Post-run Inspection of the gasifier showed that the gasifier bed thermocouple lance, a 3/4-inch SS pipe, was severed about 2 feet above the steam-oxygen nozzle. Some agglomerates of char were retrleved from the gasifier vessel that could have diverted a sand-blast jet to the lance. The longest bed differential pressure probe was also cut at a 45 degree angle. The lance cutoff could have also interfered with the incoming feed, blocking the mixing, and caused the clumping of the feed.

Test T12-2. The lance was repaired and reinforced and a successful gasification test at $1500^{\circ} \mathrm{F}$ and 102 psig (T12-2) was made on July 18 and 19 , 1985. This second test of the long-term PRU test series logged 20 hours of steady-state operation, surpassing the 12 hour test goal.

The feed material again was whole tree chips obtained from Wisconsin. The test was conducted at a pressure of 102 psig because internal wear degraded the feedwater pump supply pressure to the boller. The pump could only produce 350 psig, which was insufficlent to supply steam to the flow measurement orifices required for operation at 300 psig system pressure. A new pump was installed for the 3-day steady-state period test that was conducted in August. In preparation of the PRU system for the 3 day test, all lines, filters, and instrument taps were cleaned and all mechanical equipment was lubricated.

Test 3D-1. The 3-day steady-state operation period was conducted at $1550^{\circ} \mathrm{F}$ and 309 psig during the week of August 12, 1985. The test covered two periods with different feed rates; 430 and $750-1 \mathrm{~b} / \mathrm{h}$. The test began with the lower feed rate to allow the entire PRU and piping system to come to thermal equilibrium with the ambient conditions. A minor problem was corrected during the lower feed rate perlod without shutting down the gasifier. The difficulty was that dust accumulation in the 18-inch slide-gate valve bonnet prevented the gate from being fully opened by about 5 inches. This incomplete retraction of the slide-gate promoted bridging of part of the drop charge from the weigh bin to the lockhopper, and the balance of each charge had to be manually assisted. Overa11, the PRU performed well in this extended period. Valuable additional information was provided on long duration process operation, such 
as the possible breakthrough observation of minor or very low concentration process components, the equilibration of vessel temperature gradients to establish a true process heat balance, and long-term equipment operation handling dust and tar containing streams.

Tests T12-3 and T12-4. The last two tests of the program were conducted in September and October of 1985 with each test consisting of two different process parameter set points. Test T12-3 was conducted on September 18 and 19. The gasification period was maintained for 12 hours at 303 psig pressure, but within this period two gasification test temperatures of $1413^{\circ}$ and $1672^{\circ} \mathrm{F}$ were studied. Each steady period was maintained for about 4 hours. Test T124 was conducted on October 9 and 10 at $69 \mathrm{psig}$ and $1510^{\circ} \mathrm{F}$. Again, two gasification periods with different operational set points were conducted in this test. The first gasification period was operated with a fluidized-bed L/D ratio of 3 to 4 . Additional inert bed material was then added after the first period to increase the fluidized-bed L/D ratio to about 5 to 6 .

Task V. Data Review for Scale-Up Tests

The following sections present the gasification test reslts, analysis, effect of various parameters, and information relative to process scale-up. The gasification and process performance data in this analysis were obtained from PRU test operations conducted over steady gasification periods of up to 3 days and from the process parameter variation tests of 4- and 12- hour steady-state periods. The startup and shutdown phases of the PRU operation were each done slowly in 8-hour periods before and after the gasification periods and are mainly pertinent for the operation of the PRU. The adiabatic process data from the PRU system is detailed in the following section and is necessary to identify the optimum process conditions for a proposed scaled-up application.

Figure 33 presents the chronological history of key inputs and fluidizedbed temperature for the 3-day steady duration PRU gasification test. No differences in performance were evident between the shorter steady gasification test periods and the 3-day test, indicating that the heat and material balances from the shorter tests reflect the true, adiabatic process. The normal feed rates of up to $1000 \mathrm{lb}$ biomass per hour and the normal fluidizedbed volumes used in the tests results in approximately 15 bed turnovers of material per hour. Hence, a steady-state test of about 4 hours duration is in a we11-defined steady state regime. 
BIOMASS FEED, Ib/h

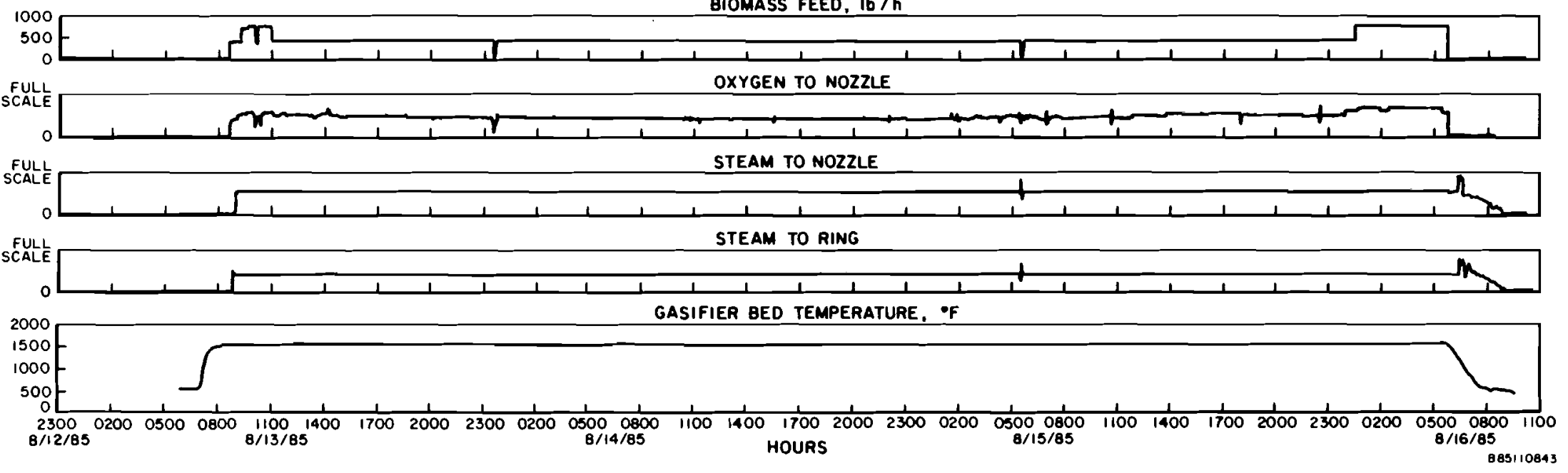

Figure 33. CHRONOLOGY OF SELECTED PROCESS CONTROL PARAMETERS DURING TEST T3D-1 
Table 15 summarizes the results from the 19 tests that achieved steadystate operation periods of 4 hours or more. Material and energy balances for each Individual test are presented in Appendix E. Corrections were made to the raw data to establish $100 \%$ elemental and material balances before correlating the data for process evaluation purposes. Appendix F lists the properties of entrained solids for each test. The size analysis of the entrained solids show that none of the inert solids are carried over with the raw gases. Hence, the PRU operation resulted in the discharge of feed ash containing some unconverted carbon, with the product gas stream.

Tests GT-1 through GT-11 and GT-16 were conducted using maple wood chips from northern Wisconsin as feed material. Whole tree chips from Pennsylvania were used as feed material for Tests GT-13, GT-14, GT-15, and GT-17. Whole tree chips were also used as feed materlal for the subsequent long duration tests except that this feed material was obtained from Wisconsin. Representative samples of the prepared wood feed were analyzed for their physical and chemical properties. The proximate analysis, ultimate analysis, bulk density, and gross heating value of typical samples of maple wood chips and whole tree chips are given in Table 17.

\section{Effect of Temperature}

The first tests that were conducted obtained data on the effect of temperature on gasifier performance. The gasifier was operated at a pressure of $300 \mathrm{psig}$ and temperatures ranging from $1390^{\circ}$ to $1800^{\circ} \mathrm{F}$.

The results from these tests are plotted In Figures 34 through 37 and show the effect of temperature on process performance. The temperature value used in these plots is an average of at least four thermocouples inside the fluidized bed at vartous heights covering a fluidized-bed helght of up of to 74 inches above the oxygen distributor. In these tests the measured differences in temperature between these thermocouples was from $45^{\circ}$ to $90^{\circ} \mathrm{F}$. An additional 12 thermocouples are tack welded to the outside of the PRU fluidized-bed liner.

Figure 34 shows the oxygen required to achieve average fluidized-bed gasification temperatures ranging from $1390^{\circ}$ to $1800^{\circ} \mathrm{F}$ at about $300 \mathrm{psig}$. The oxygen values reported here for these tests are given per pound of feed dried to $10 \%$ molsture leve1. Oxygen demand at a given temperature increases as the 
Table 17. TYPICAL WOOD FEED PROPERTIES

$$
\text { Maple Wood* } \begin{array}{cc}
\text { Whole Tree } & \begin{array}{c}
\text { Whole Tree } \\
\text { Chips* From } \\
\text { Pennsylvania }
\end{array} \\
\hline
\end{array}
$$

Proximate Analysis, wt \%

Moisture

Volatile Matter

Ash

Fixed Carbon (By Diff.)

Total

Ultimate Analysis, wt \%

As $h$

Carbon

Hydrogen

Sulfur

Nitrogen

Oxygen (By Diff.)

Total

Bulk Density, $1 \mathrm{~b} / \mathrm{ft}^{3}$

Gross Heating Value, Btu/1b

Ash Fusion Temperature, ${ }^{\circ} \mathrm{F}$

$$
12.26
$$

73.94

0.43

$\frac{13.37}{100.00}$

0.50

49.54

6.11

0.02

0.10

$\frac{43.73}{100.00}$

16.6

8306

$>2700$
10.89

73.53

0.84

$\frac{14.74}{100.00}$
7.72

77.07

0.75

14.46

100.00

* Average of two samples (Tests GT-9 and GT-10).

** Average of two samples (Tests GT-12 and GT-13).

$\dagger$ Average of two samples (Test T12-2).

ESTIMATED SPECIE COMPOSITION OF TEST FEEDSTOCKS

Feedstock

Maple Wood

Whole Tree Chips from Pennsylvania

Whole Tree Chips from Wisconsin
Estimated Specie Composition, vol \%

$100 \%$ maple pulpwood

$90 \%$ red oak, balance chestnut, aspen, black birch

$34 \%$ maple, $33.5 \%$ oak, $19.6 \%$ birch, $12.9 \%$ pine and brush 


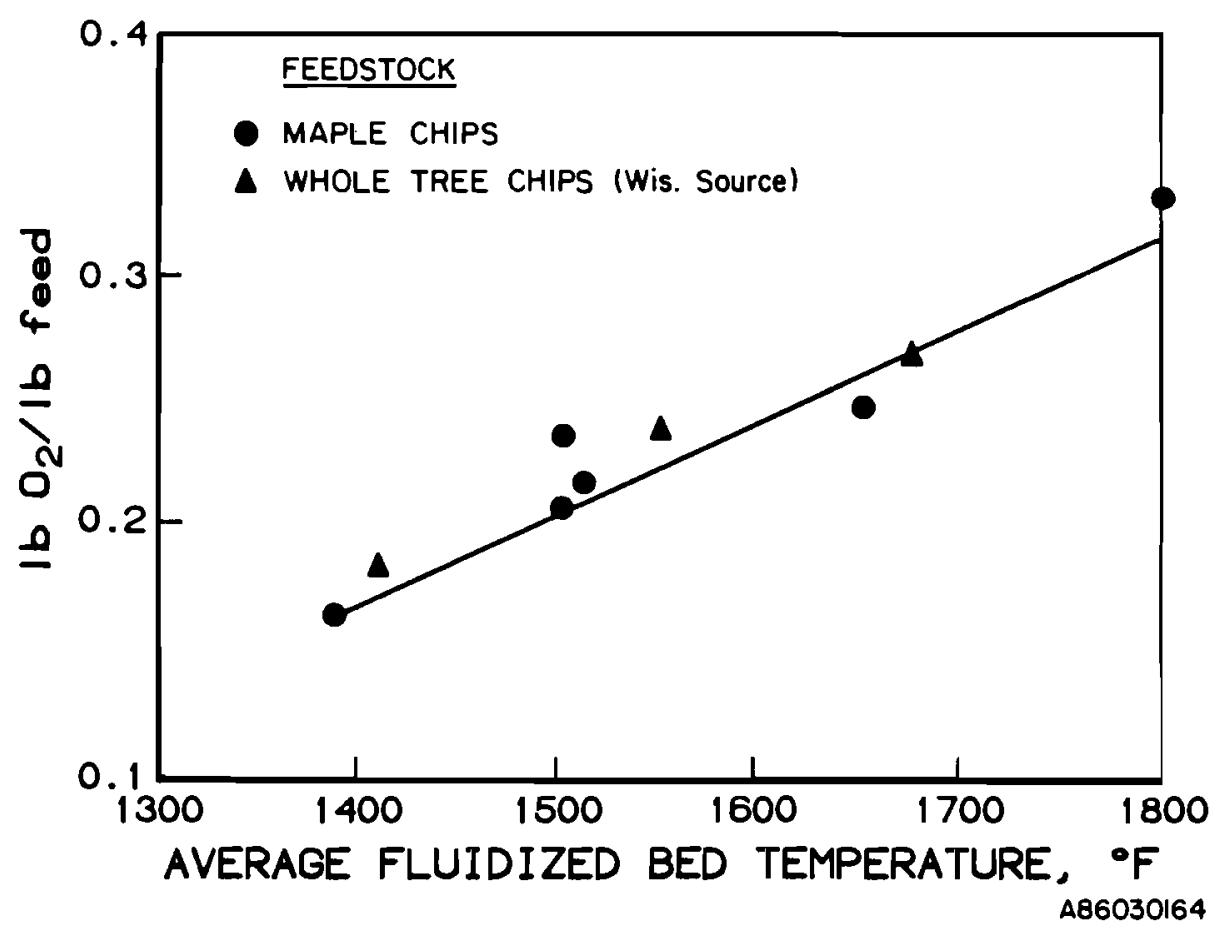

Figure 34. OXYGEN REQUIRED AS A FUNCTION OF GASIFICATION TEMPERATURE

(Maple Feed: Tests GT-1 Through GT-8 and Wisconsin Whole Tree Chips: Tests T12-3a, T12-3b, T3D-1b)

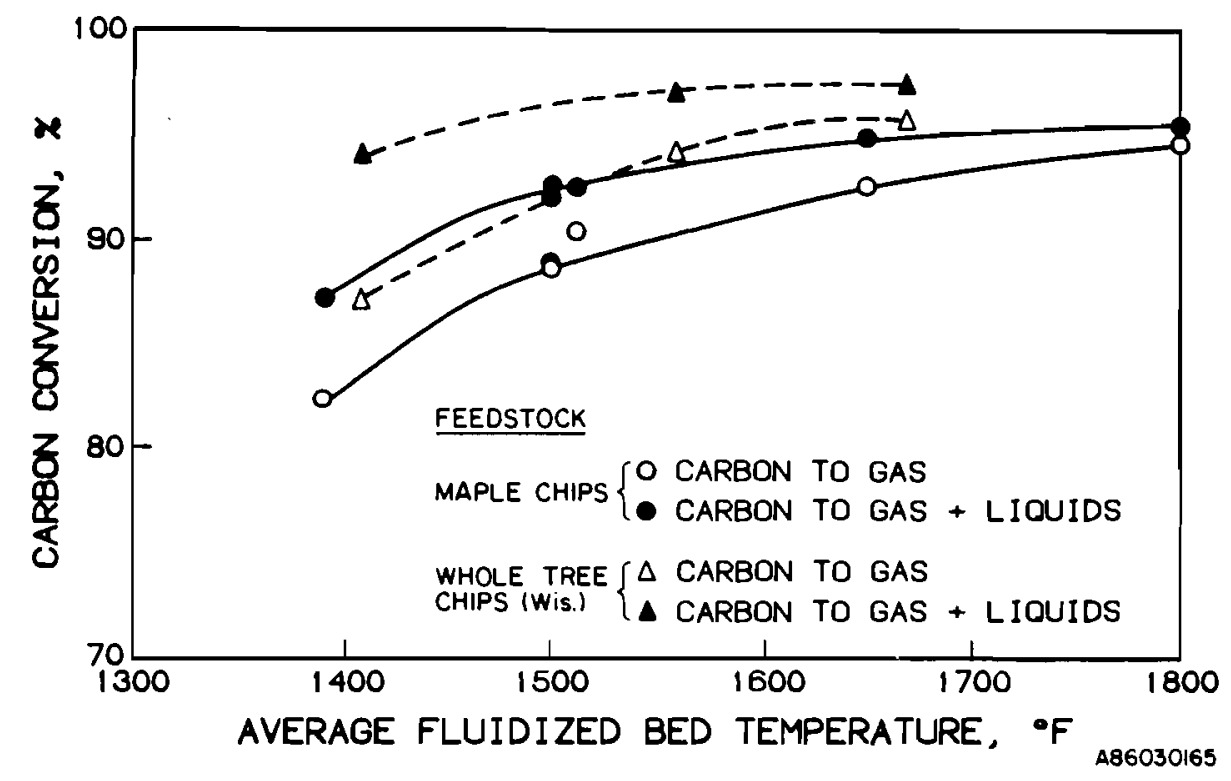

Figure 35. FEED CARBON CONVERSION AS A FUNCTION OF GASIFICATION TEMPERATURE (Maple Feed: Tests GT-1 Through GT-8 and Wisconsin Whole Tree Chips: Tests T12-3a, T12-3b, T3D-1b) 


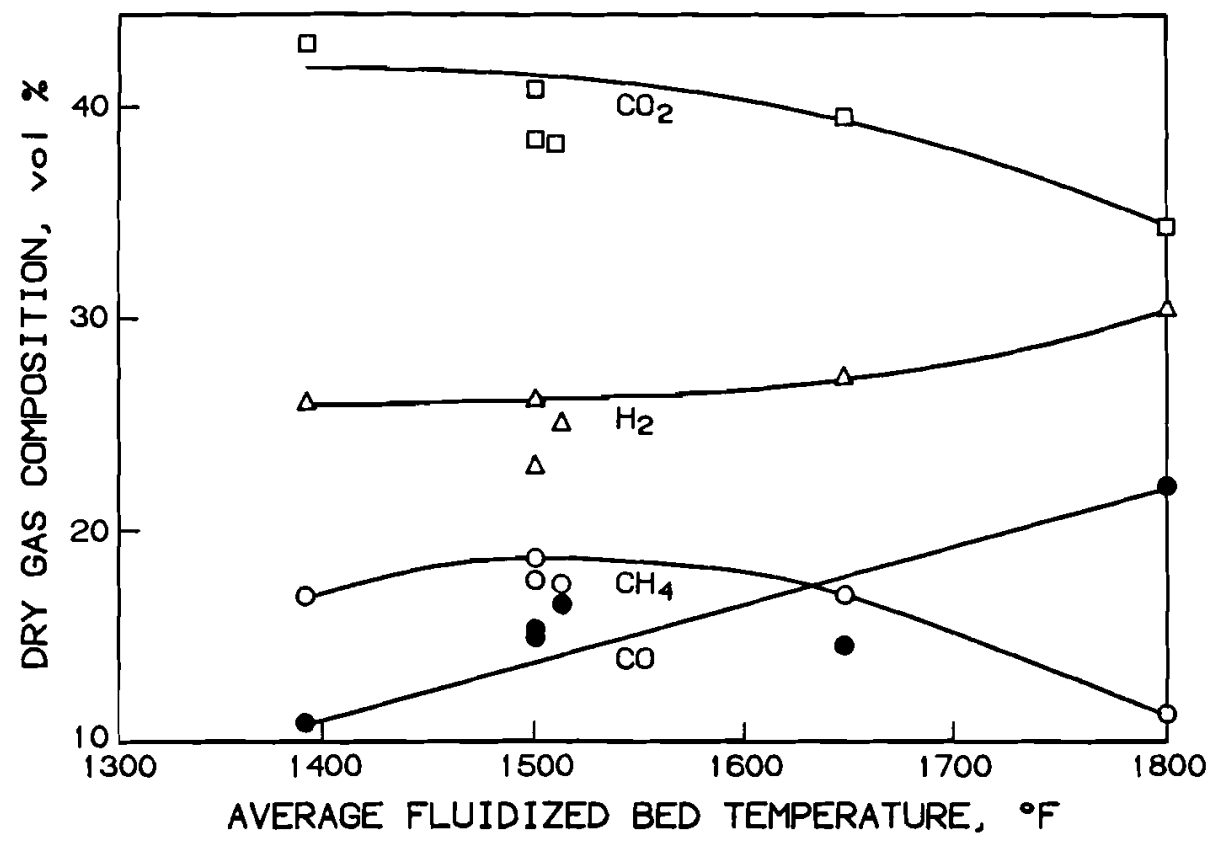

F1gure 36. PRODUCT GAS COMPOSITION AS A FUNCTION OF GASIFICATION TEMPERATURE (Maple Feed: Gasification Tests GT-1 through GT-8)

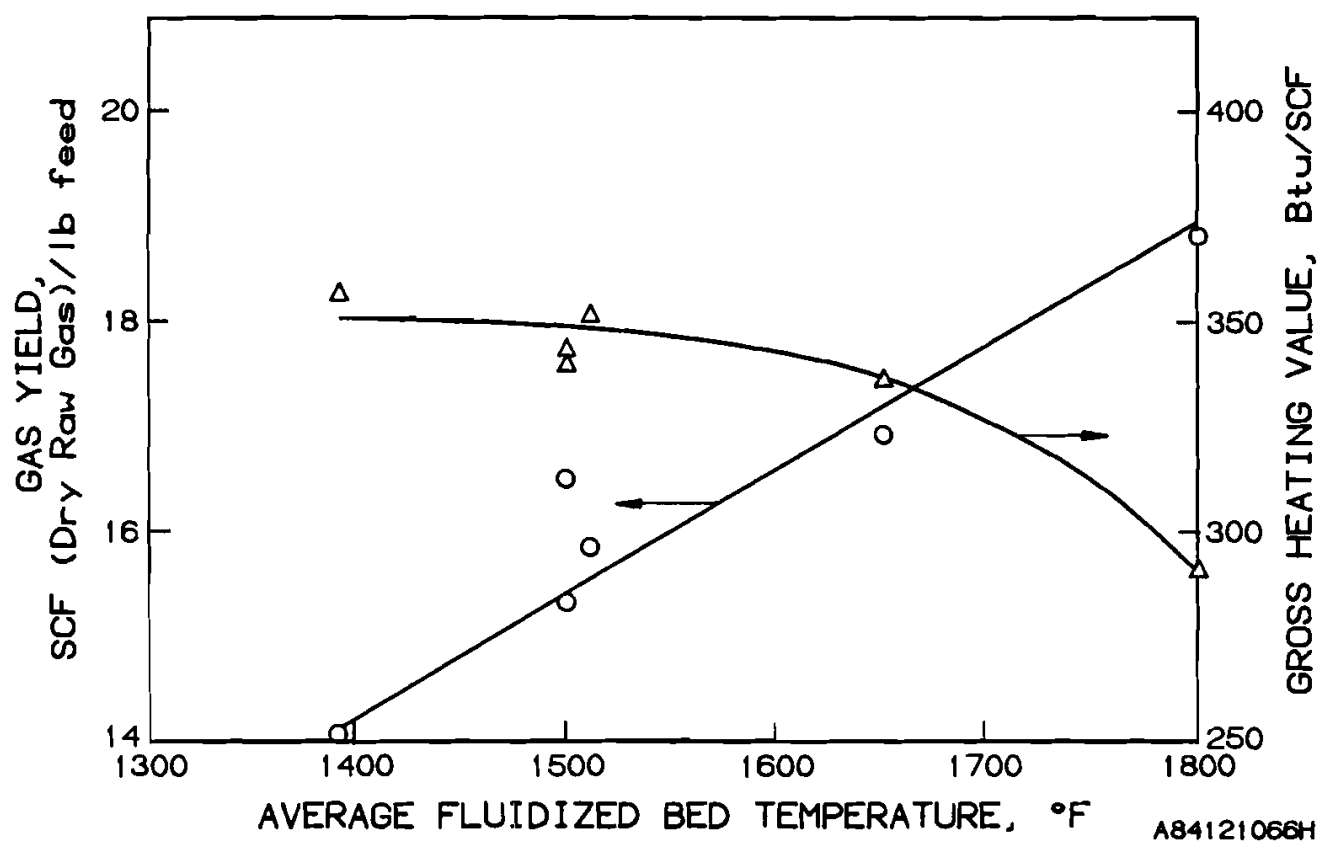

F1gure 37. GAS YIELD AND HEATING VALUE AS A FUNCTION OF TEMPERATURE (Maple Feed: Gasification Tests GT-1 Through GT-8) 
feed molsture content increases (see Tests GT-13, GT-14, GT-15, and GT-17 in Table 15), so the representative level of $10 \%$ feed moisture was chosen in the gasification tests as any commercial process would operate at a molsture level somewhat above bone dry.

The measured oxygen requirement vartes from $0.17 \mathrm{lb}$ oxygen/1b feed for the test at $1390^{\circ} \mathrm{F}$ to $0.34 \mathrm{lb}$ oxygen/lb feed for the highest temperature test at $1800^{\circ} \mathrm{F}$. For the gasification tests with maple hard wood at $1500^{\circ} \mathrm{F}$ and $300 \mathrm{psig}$, the oxygen required was in the range of 0.21 to $0.241 \mathrm{~b} / 1 \mathrm{~b}$ of approximately $10 \%$ moisture feed. Gasification of Pennsylvania whole tree chips at the same operating conditions required 0.23 to $0.251 \mathrm{~b}$ oxygen/1b feed and the Wisconsin whole tree chips required 0.23 to $0.27 \mathrm{lb}$ oxygen/1b feed. It is possible that the higher bark content in the whole tree chips, compared to the pulpwood quality maple chips, may be the reason for the slightly higher oxygen requirement.

As expected, carbon conversion in the gasification process increases with increasing fluidized-bed temperature as shown in Figure 35. The total carbon conversions for all the tests, at $1500^{\circ} \mathrm{F}$ and $300 \mathrm{ps} 1 \mathrm{~g}$, is in the range of $92 \%$ to $96 \%$, except Test GT-13, which has a measured carbon conversion of $89.9 \%$. In this one case, the olls and tar yields measured were unusually low, and a $2 \%$ increase in the measured ofl yield value (typical of other tests) would raise the total carbon conversion to the same level.

The carbon utilization could be further improved by recycling the elutriated carbon to the high-temperature region of the gasifier. Figure 35 also shows the amount of condensibles produced decreases with increasing temperature. The olls and tar yields for all the tests at $1500^{\circ} \mathrm{F}$ and $300 \mathrm{psig}$, for the three feedstocks, are in the range of 1.8 to $2.21 \mathrm{~b} / 100 \mathrm{lb}$ feed. These condensible organics would contribute heating value to the fuel gases in applications where.noncondensing conditions could be maintained between the gasifier and the combustor. In processes where the condensibles would have to be separated, the oils and tars could be gasified by recycling to the high-temperature gasification zone.

The effect of gasification temperature on gas composition is shown in Figure 36. In the temperature range of $1390^{\circ}$ to $1800^{\circ} \mathrm{F}$, the methane content reaches a maximum at about $1500^{\circ} \mathrm{F}$ and is reduced at higher temperatures. The hydrogen concentration increases with temperature; the observed hydrogen is 
produced during biomass devolatilization, steam-char gasification, and the reforming of light and heavy hydrocarbons. Superimposed on these reactions is the water-gas shift reaction, which further alters the overall gas composition. As expected, carbon monoxide increases steadily with temperature, whereas temperature has an Inverse effect on carbon dioxide.

The gas ylelds and their gross heating values are shown as a function of temperature in Figure 37 . The results conform with the anticipated trends of Increased gas ylelds coupled with decreasing heating value as the gasification temperature is raised. The reforming of light hydrocarbons, such as methane and ethane, above $1500^{\circ} \mathrm{F}$ is the reason for the reduction in the fuel gas heating value. The heating value is about $350 \mathrm{Btu} / \mathrm{SCF}$ at $1500^{\circ} \mathrm{F}$, which is considered a good quality medium-Btu gas.

\section{Effect of Steam Feed Rate}

With maple wood chips, Tests GT-1, GT-6, GT-8, and GT-9 were conducted at different steam-to-wood ratios ranging from 0.50 to $0.86 \mathrm{lb}$ steam/1b biomass feed. For the analyzed results for these tests it is observed that steam feed rate has very little effect on gas composition as shown in Figure 38 . The small variations in the concentrations of $\mathrm{CO}_{2}, \mathrm{H}_{2}, \mathrm{CH}_{4}$, and $\mathrm{CO}$ can be attributed to the small differences in pressure and temperature that may alter the extent of the water-gas shift reaction and reforming of hydrocarbons. The biomass carbon conversion 1 s also not affected by the amount of steam input. The total carbon conversion is $92 \%$ for three of the tests and $92.7 \%$ for the other test. The results also show, as expected, that additional steam input contributes only to the undecomposed steam content in the product gas and does not affect the relative content of other gaseous constituents. This 1s, however, slightly different for the whole tree chip feedstocks from Pennsylvania and Wisconsin, which show some variations as indicated in Figures 39 and 40 . The gas composition is at most slightly affected by steam input amounts; however, the character of the ofls and tars from these tests is significantly affected as is shown later.

\section{Effect of Operating Pressure}

Test GT-10 was operated at $90 \mathrm{psig}$ to investigate the effect of system pressure on gasifier performance, using maple wood chips as feed material. Results from this test were compared with Test GT-8 conducted at 300 psig 


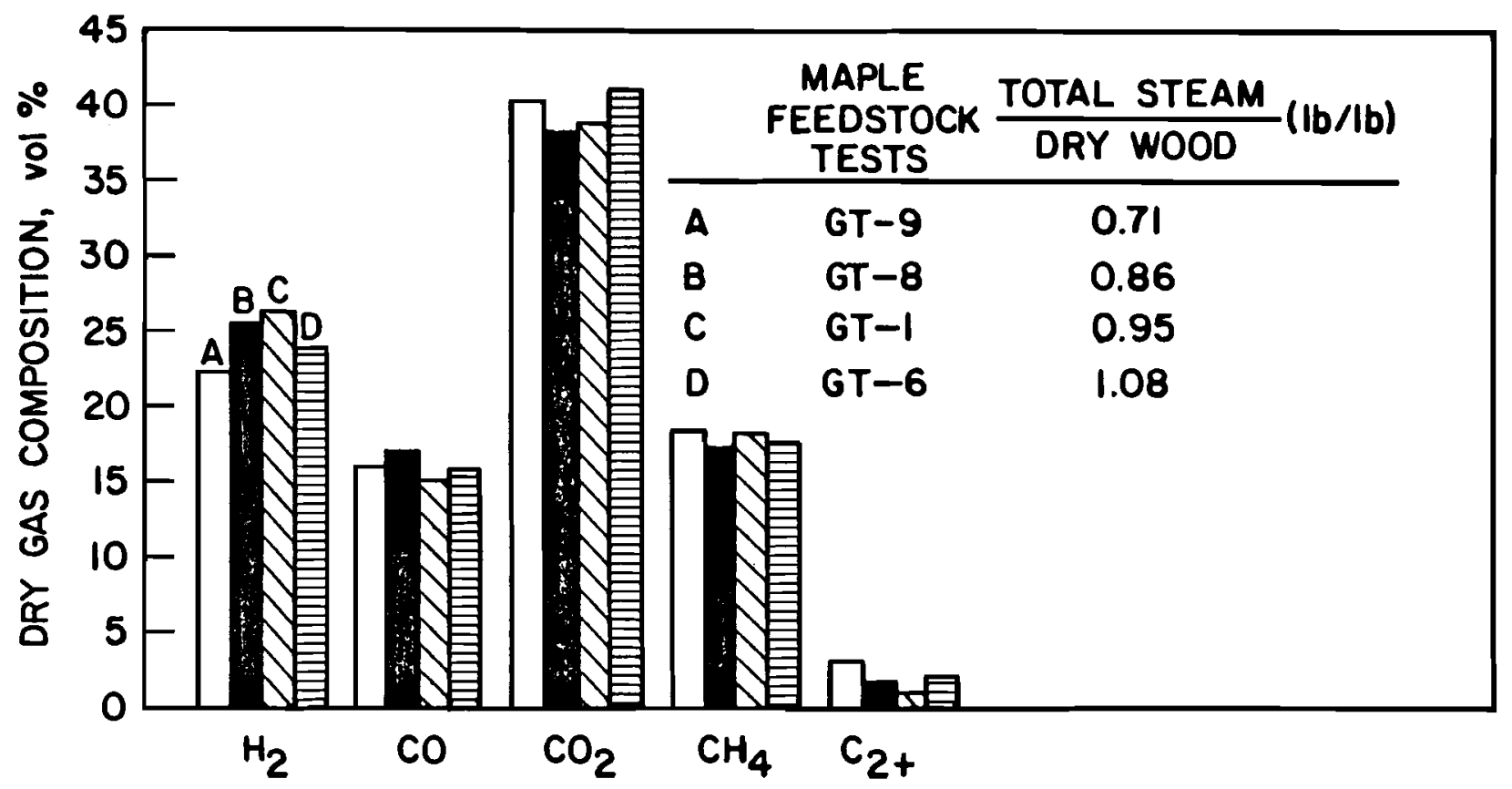

Figure 38. EFFECT OF STEAM ON PRODUCT GAS COMPOSITION (Maple Feed) 


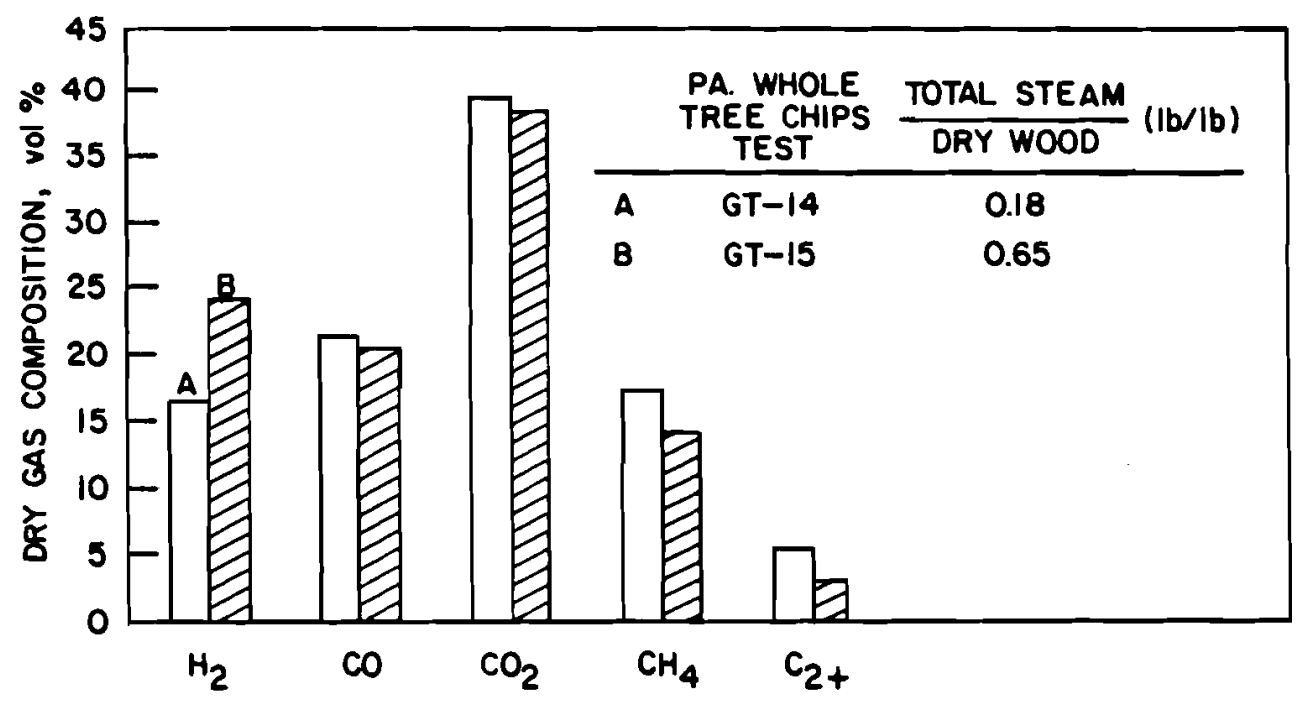

Figure 39. EFFECT OF STEAM ON PRODUCT GAS COMPOSITION (Whole Tree Chips From Pennsylvania)

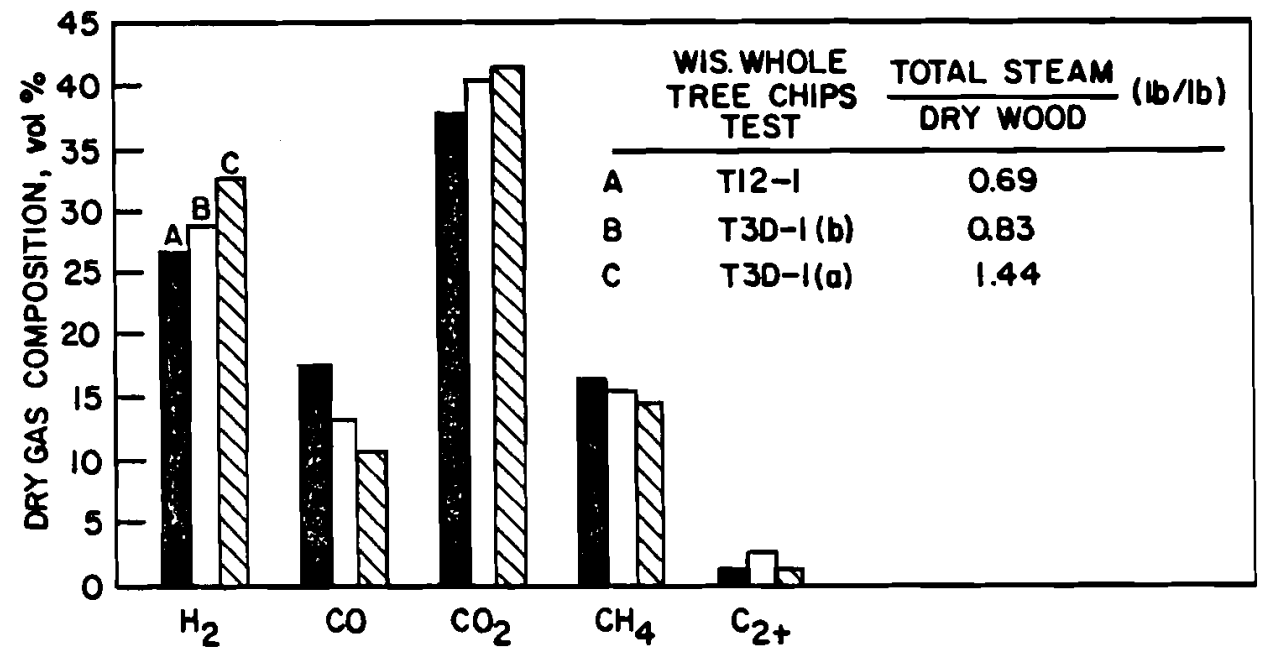

Figure 40. EFFECT OF STEAM ON PRODUCT GAS COMPOSITION (Whole Tree Ch1ps From W1sconsin) 
because of the similar steam and oxygen feed rates relative to the biomass feed rate. For the low-pressure case, in order to maintain the proper superficlal gas velocity in the gasifier, the throughput rate was decreased by about 50\% in comparison to Test GT-8. Under the conditions of different through-put rates at different pressures, the comparison shows that the lowpressure gasification test resulted in a higher carbon conversion to gas and a lower production of oils and tars. A comparison of the gas composition shows that the concentration of the major gaseous components is nearly the same, except for the anticlpated lower methane yield at the lower pressure. The apparent higher hydrocarbons content in the product gas for Test GT-10 explains the higher heating value and consequently the higher cold-gas thermal efficiency in comparison to Test GT-8.

A comparison of Tests $\mathrm{T} 12-1$ and T12-2 with the 12 hour steady-state gasification periods conducted at $300 \mathrm{psig}$ and $102 \mathrm{psig}$, respectively, with Wisconsin whole tree chips shows that the low-pressure test resulted in slightly lower carbon conversion. However, the methane content is lower and higher concentration of higher hydrocarbons are observed in the low-pressure Test T12-2 in comparison to the high-pressure Test T12-1. Because of the high concentration of the higher hydrocarbons, the low-pressure gasification test resulted in a higher dry inert-free heating value gas compared to the latter. But, due to the lower carbon conversion and gas yleld, the cold-gas thermal efficiency for the low-pressure test is lower than that of the high-pressure test.

\section{Effect of Feed Rate}

The operating conditions for Test GT-11 were $1500^{\circ} \mathrm{F}$ and $300 \mathrm{psig}$ at a maple wood feed rate of $1030 \mathrm{lb} / \mathrm{h}$. The wood feed rate was increased in a stepwise manner to $1030 \mathrm{lb} / \mathrm{h}$, which was the PRU design capacity, and maintained at this feed rate for a steady-state period of 4-1/2 hours before the test was voluntarily terminated.

A comparison of the results from Tests GT-9 and GT-11 in Table 15, shows the effect of the variation in feed rates. The oxygen requirement, total carbon conversion, product gas heating value, calculated cold gas thermal efficiency, and gas yield per pound of biomass feed are roughly the same for both tests. The only apparent difference is in the product gas composition. The higher feed rate test shows higher carbon monoxide and lower carbon 
dioxide concentrations, which could be simply a function of the extent of the water-gas shift reaction occurring within the gasification system. Similar carbon conversions and cold-gas thermal efficlencies show that the PRU did not approach its 11miting throughput rate at the $1030 \mathrm{lb} / \mathrm{h}$ value.

Effect of Feedstock Type and Role of Steam

Test GT-13 was the first test using whole tree chips as feed material. No operational difficulties were encountered during the approximately 4-hour steady-state period with this waste feedstock.

Test GT-14 was conducted to investigate gasifier operation with no external steam addition other than that from the moisture content of the whole-tree-chip feed and the chemically produced water. Steam produced from the $15 \%$ molsture in the wood feed and from chemically produced water accounted for a steam-to-wood ratio of $0.23 \mathrm{lb} / 1 \mathrm{~b}$. For this test, the steam normally used was replaced with nitrogen to maintain a minimum fluidization velocity near the oxygen distributor and the feed location. The nitrogen was heated to about $900^{\circ} \mathrm{F}$ before entering the gasifier distributor ring and nozzle. No operational difficulties were encountered using nitrogen gas as the fluidizing medium.

For Test GT-15, the PRU steam flow control system was modified to permit nitrogen to $\mathrm{mix}$ with steam at the entrance to the gasifier. This provided a steam-to-wood ratio of $0.41 \mathrm{lb} / 1 \mathrm{~b}$ for this test. With the existing system $1 \mathrm{t}$ is not possible to superheat both nitrogen and steam; therefore, cold nitrogen was added to steam, reducing the fluldizing-gas temperature to $640^{\circ} \mathrm{F}$ from the normal operating temperature of about $800^{\circ}$ to $850^{\circ} \mathrm{F}$. To obtain a gasifier bed temperature of $1500^{\circ} \mathrm{F}$, increased oxygen flow was required to compensate for the mixture of cooler flufdizing steam and nitrogen.

A comparison of the dry gas compositions from Tests GT-14 and GT-15 in Figure 39 shows a higher carbon monoxide content and a lower hydrogen concentration in Test GT-14. This difference can be attributed to the low steam-to-wood ratio in Test GT-14, which could alter the extent of the watergas shift equilibrium reaction. Less of the higher hydrocarbons were observed in Test GT-15, suggesting their possible reforming in the presence of excess steam. 
Effect of Bed Height

The purpose of Test GT-16 was to Investigate the effect of bed height on process performance. The fluidized-bed L/D was kept between 3 and 4 compared with previous maple wood feed tests with a ratio of about 6 . Results from Test GT-16 were compared with those from Tests GT-1 and GT-8. A11 three tests were conducted with otherwise similar operating conditions using maple wood chips as feed material. The results indicate that Test GT-16 produced a lower methane concentration coupled with higher concentrations of ethane and $\mathrm{C}_{6}+$ hydrocarbons. This could be attributed to the lower gas residence time in the inert solids fluidized-bed reactor section allowing less time for reforming of hydrocarbons.

Effect of Moisture

Comparing Test GT-17 with a higher feed moisture to Test GT-15 with a lower feed moisture, but otherwise similar operating conditions, there is also a significant difference in the product gas concentrations of $\mathrm{CO}$ and $\mathrm{CO}_{2}$ in addition to the obvious increase in oxygen demand for the higher moisture content feed material. The higher moisture feed produces a product gas with a higher concentration of $\mathrm{CO}_{2}$ and a lower concentration of $\mathrm{CO}$ when compared with the test with a lower molsture content feed material. This can be explained by the higher demand for combustion for drying blomass inside the gasifler, and the simultaneously occurring water-gas shift reaction in which there is more water avallable to convert $\mathrm{CO}$ to $\mathrm{CO}_{2}$ and $\mathrm{H}_{2}$. A comparison of the measured raw gas composition with the calculated equilibrium gas composition shows that the gas composition is closer to equilibrium in the higher feed molsture content test. The high molsture feed test also resulted in little or no olls and tars compared to the nearly $2 \%$ olls and tars measured in Test GT-15. It is not clear whether the higher oxygen demand for the high moisture feed, extended the combustion zone within the gasifier to the extent that the devolatilized ofls and tars were selectively combusted as they were formed or whether there were slight measurement errors. The lower product gas heating value can be attributed to the lower amounts of higher hydrocarbons produced from the higher molsture feed material. 


\section{Environmental Aspects}

Some of the by-products of biomass gasification will require treatment or removal before they can be discharged to the environment. These include ammonia, phenols and other organic acids, benzene, and polyaromatic hydrocarbons and potentially, sulfur-containing gases. Due to the low sulfur content ( 0.02 to 0.04 weight percent) of the feedstock, the formation of sulfur compounds is well within all foreseeable standards. Small amounts ( 0 to $150 \mathrm{ppm}$ ) of cos were occasionally found in the product gas sample bombs, but no $\mathrm{H}_{2} \mathrm{~S}$ has been detected to date.

Ammonia, phenol, cresols, acetic acid, methanol, and other water-soluble heterocyclic organic compounds were found in the aqueous phase of the gasifier condensate. Due to the presence of ammonia, the $\mathrm{pH}$ of the condensate was generally around 8.0, and it was well-buffered, which is favorable for blological wastewater treatment processes which are sensitive to $\mathrm{pH}$. The levels of all water-soluble organic species in the condensate are indicated by total organic carbon (TOC). It was found that TOC in the aqueous effluent declines with increasing gasification temperature; this is shown in Figure 41.

An ofl phase is also present in the gasifier condensate. This has been extensively analyzed by GC/MS, and the results are tabulated in Table 18. 011 components were predominantly aromatic hydrocarbons, with naphthalene and benzene as the most abundant species. In contrast to coal-derived ofls, no aliphatic hydrocarbons were identified, although some could be present in the unidentified portions, which comprised $3 \%$ to $11 \%$ of the total o1l. Oxygenated species accounted for $0.4 \%$ to $7.5 \%$ of the oll collected and included phenols, naphthols, and furans. Nitrogen- and sulfur-contalning ofl components were very low, which is to be expected from the low sulfur and nitrogen content of the feed.

Polyaromatic hydrocarbons ( $\mathrm{PAH}$ ) are organlc compounds containing two or more fused benzene rings. Two- and three-ring hydrocarbons, such as naphthalene and phenanthrene, do not pose any special environmental hazards. Compounds with four or more condensed rings, however, generally 1nclude hazardous substances such as fluoranthene, chrysene, and benz(a)pyrene. In this section, PAH w1ll refer to the latter class of compounds, those with more than three fused rings. Although higher temperatures tend to favor the condensation reactions that produce these substances, the data show that the 


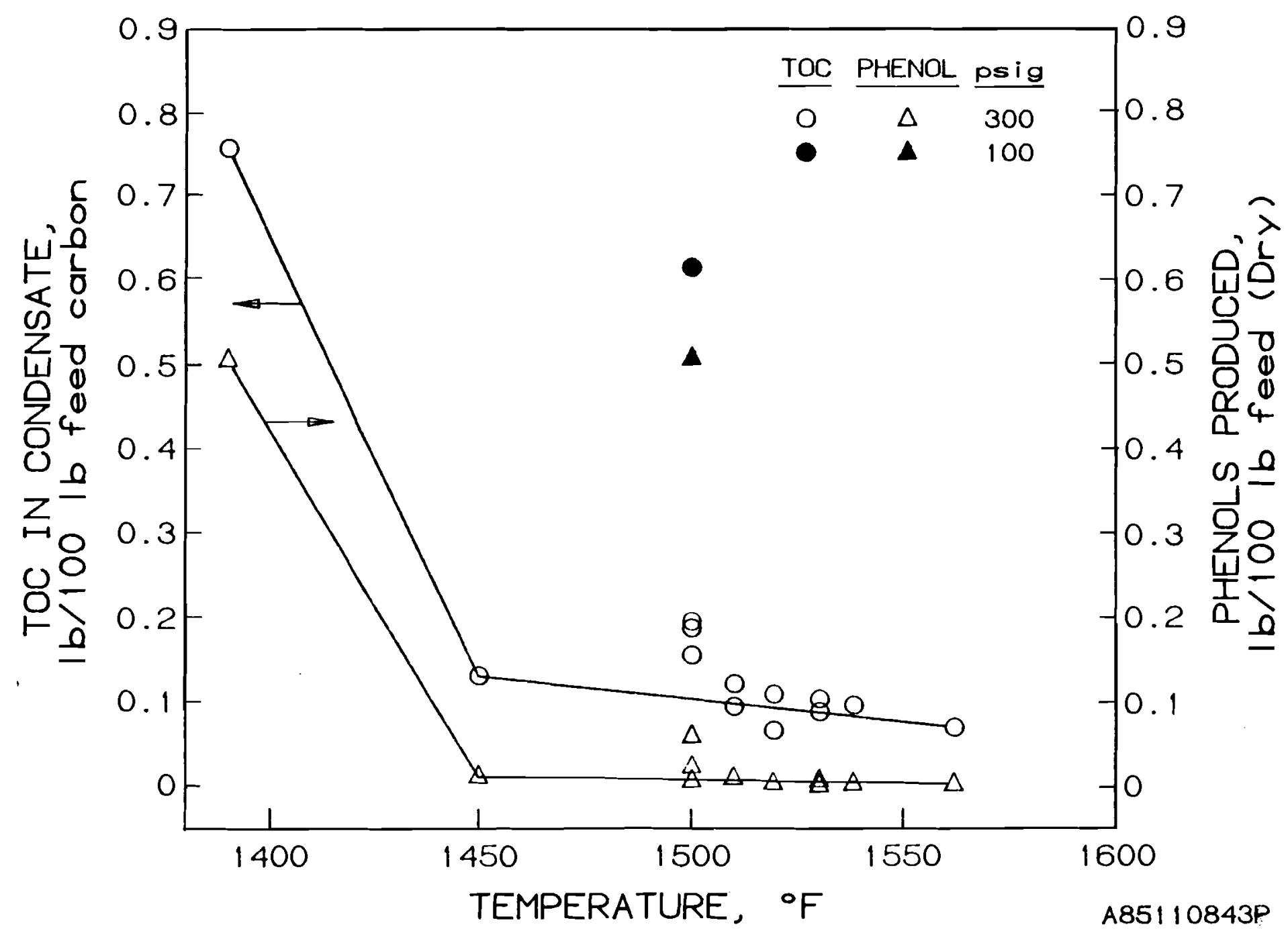

Figure 41. PRODUCTION OF PHENOLS AND TOTAL ORGANIC CARBON IN CONDENSATE AS A FUNCTION OF GASIFICATION TEMPERATURE 
Table 18. COMPOSITION OF OILS FOUND IN PRODUCT GAS

IN PRU GASIFICATION TESTS

\begin{tabular}{|c|c|c|c|c|c|c|c|c|c|}
\hline Test No. & $\underline{G T-5}$ & GT-6 & $\underline{G T-8}$ & $\underline{G T-9}$ & $\underline{G T-10}$ & $\underline{G T-11}$ & $\mathrm{GT}-13$ & GT-14 & $\underline{G T-15}$ \\
\hline Temperature, ${ }^{\circ} \mathrm{F}$ & 1390 & 1500 & 1510 & 1500 & 1465 & 1500 & 1520 & 1510 & 1520 \\
\hline 011 Yleld, 1b/100 1b blomass" & 2.84 & 2.18 & 1.33 & 1.83 & 0.34 & 2.33 & 1.66 & 3.00 & 2.26 \\
\hline \multicolumn{10}{|l|}{ Products, wt $Z$ in 0118} \\
\hline One-RIng Hydrocarbons & 28.6 & 30.6 & 24.4 & 40.8 & 15.0 & 39.9 & 8.4 & 31.2 & 26.8 \\
\hline Benzene & 8.9 & 24.9 & 20.1 & 36.2 & 4.1 & 34.9 & 6.1 & 23.7 & 23.9 \\
\hline Toluene and Xylenes & 12.1 & 2.9 & 2.3 & 2.1 & 2.9 & 2.3 & 0.7 & 4.7 & 1.2 \\
\hline Others & 7.6 & 2.8 & 2.0 & 2.6 & 8.0 & 2.7 & 1.6 & 2.9 & 1.7 \\
\hline Two-R1ng Hydrocarbons & 28.8 & 39.0 & 39.5 & 33.5 & 40.4 & 29.7 & 54.5 & 32.2 & 36.5 \\
\hline Naphthalene & 17.6 & 32.2 & 32.1 & 28.4 & 26.5 & 24.5 & 48.7 & 25.7 & 30.3 \\
\hline Methylnaphthalene & 4.5 & 0.9 & 0.8 & 0.6 & 3.0 & 0.6 & 0.6 & 1.2 & 0.6 \\
\hline Other $\mathrm{s}$ & 6.7 & 5.9 & 6.6 & 4.5 & 11.0 & 4.5 & 5.3 & 5.4 & 5.6 \\
\hline Three-Rdng Hydrocarbons & 14.0 & 10.8 & 13.2 & 9.1 & 20.3 & 10.3 & 12.3 & 11.6 & 11.7 \\
\hline Fluorene & 3.5 & 2.8 & 2.6 & 2.2 & 4.3 & 2.2 & 3.2 & 2.2 & 2.3 \\
\hline Phenanthrene and Anthracene & 5.8 & 7.0 & 8.6 & 5.9 & 11.8 & 6.6 & 7.9 & 7.5 & 7.9 \\
\hline Other 8 & 4.7 & 1.8 & 2.0 & 1.0 & 4.3 & 1.5 & 1.3 & 1.9 & 1.5 \\
\hline Four-RIng Hydrocarbons & 9.6 & 9.7 & 13.3 & 8.2 & 13.2 & 10.7 & 10.1 & 10.8 & 12.6 \\
\hline Five-Ring Hydrocarbons & 2.2 & 2.2 & 2.6 & 2.4 & 2.5 & 3.1 & 4.1 & 4.4 & 4.7 \\
\hline H1gher Aromatic Hydrocarbons & 0.0 & 0.8 & 1.4 & 1.8 & 1.0 & 1.9 & 1.6 & 2.4 & 2.6 \\
\hline Tota1 Hydrocarbons & 83.2 & 93.1 & 94.4 & 95.8 & 92.4 & 95.6 & $\underline{91.1}$ & $\underline{92.6}$ & 94.8 \\
\hline 0-Containing Compounds & 7.5 & 1.1 & 0.9 & 0.7 & 3.5 & 1.0 & 0.5 & 1.9 & 0.4 \\
\hline Phenol and Cresols & 3.2 & 0.1 & 0.04 & 0.1 & 0.4 & 0.1 & 0.0 & 0.9 & 0.04 \\
\hline Benzofurans and Dibenzofurans & 3.7 & 1.0 & 0.6 & 0.5 & 2.4 & 0.7 & 0.004 & 1.0 & 0.4 \\
\hline Others & 0.6 & 0.0 & 0.3 & 0.1 & 0.7 & 0.2 & 0.1 & 0.02 & 0.03 \\
\hline N-Containing Compounds & 0.7 & 0.4 & 0.3 & 0.4 & 0.5 & 0.5 & 0.4 & 0.9 & 0.7 \\
\hline S-Containing Compounds & 0.2 & 0.1 & 0.02 & 0.02 & 0.04 & 0.02 & 0.2 & 0.0 & 0.01 \\
\hline Total Heterocyclic Compounds & 8.4 & 1.6 & 1.2 & 1.1 & 4.0 & 1.5 & 1.1 & 2.8 & 1.1 \\
\hline Un1dent1f1ed Compounds & 8.4 & 5.3 & 4.4 & 3.1 & 3.6 & 3.0 & 7.8 & 4.6 & 4.1 \\
\hline
\end{tabular}

* Dry Basis.

$171 / 65058 \mathrm{fr}-\mathrm{t} / \mathrm{RPP}$ 
Table 18, Cont. COMPOSITION OF OILS FOUND IN PRODUCT GAS

IN PRU GASIFICATION TESTS

Test No.

Temperature, ${ }^{\circ} \mathrm{F}$

011 Y1eld, 1b/100 1b biomass*

Products, wt $Z$ in $011 \mathrm{~s}$

One-RIng Hydrocarbons

Benzene

Toluene and Xylenes

Others

Two-Ring Hydrocarbons

Naphthalene

Methylnaphthalene

Others

Three-Ring Hydrocarbons

Fluorene

Phenanthrene and Anthracene

Others

Four-Ring Hydrocarbons

Five-Ring Hydrocarbons

H1gher Aromatic Hydrocarbons

Total Hydrocarbons

o-Contalning Compounds

Phenol and Cresols

Benzofurans and Dibenzofurans

Others

N-Containing Compounds

S-Containing Compounds

Total Heterocyclic Compounds

Unidentifled Compounds

* Dry Basis.

$171 / 65058 f r-t / R P P$
$\underline{G T-16}$ T12-1 T12-2 T3D-1a T3D-1b I12-3a T12-3b T12-4a T12-4b

$\begin{array}{lllllllll}1450 & 1530 & 1500 & 1538 & 1562 & 1672 & 1413 & 1509 & 1516 \\ 1.96 & 3.16 & 3.32 & 1.65 & 1.93 & 1.12 & 3.51 & 2.69 & 2.48\end{array}$

$\begin{array}{lllllllll}31.5 & 18.2 & 23.5 & 21.8 & 26.0 & 17.2 & 38.8 & 15.1 & 11.9\end{array}$

$\begin{array}{lllllllll}26.1 & 14.9 & 9.0 & 19.5 & 23.2 & 15.6 & 27.5 & 6.6 & 6.7\end{array}$

$\begin{array}{lllllllll}2.0 & 1.0 & 7.1 & 0.8 & 1.2 & 0.6 & 6.6 & 2.2 & 1.1\end{array}$

$\begin{array}{lllllllll}3.4 & 2.3 & 7.4 & 1.5 & 1.6 & 1.0 & 4.6 & 6.2 & 4.1\end{array}$

$\begin{array}{lllllllll}33.8 & 38.3 & 39.0 & 46.9 & 39.5 & 35.9 & 35.8 & 41.8 & 42.3\end{array}$

$\begin{array}{lllllllll}28.5 & 31.9 & 27.0 & 41.1 & 33.4 & 32.7 & 27.9 & 30.2 & 32.4\end{array}$

$\begin{array}{lllllllll}0.6 & 0.4 & 3.9 & 0.6 & 0.9 & 0.5 & 1.9 & 2.2 & 1.5\end{array}$

$\begin{array}{lllllllll}4.7 & 6.0 & 8.1 & 5.2 & 5.1 & 2.8 & 6.0 & 9.4 & 8.4\end{array}$

$\begin{array}{lllllllll}9.2 & 16.6 & 12.5 & 12.1 & 12.8 & 11.6 & 9.8 & 16.0 & 14.9\end{array}$

$\begin{array}{lllllllll}2.3 & 2.3 & 2.7 & 2.6 & 2.5 & 1.3 & 3.0 & 3.6 & 2.9\end{array}$

$\begin{array}{lllllllll}5.8 & 9.7 & 7.3 & 8.2 & 8.4 & 7.9 & 4.9 & 8.9 & 8.9\end{array}$

$\begin{array}{lllllllll}1.1 & 4.6 & 2.5 & 1.3 & 1.9 & 2.4 & 1.9 & 3.6 & 3.1\end{array}$

$\begin{array}{lllllllll}8.2 & 13.4 & 7.3 & 10.9 & 11.3 & 17.1 & 5.3 & 10.6 & 12.6\end{array}$

$\begin{array}{lllllllll}3.4 & 4.9 & 3.0 & 3.1 & 3.3 & 6.8 & 1.2 & 4.1 & 5.1\end{array}$

$\begin{array}{lllllllll}2.0 & 2.6 & 0.8 & 1.1 & 1.7 & 5.7 & 1.0 & 2.8 & 3.0\end{array}$

$\underline{88.0} \quad \underline{94.0} \quad \underline{86.1} \quad \underline{95.9} \quad \underline{94.6} \quad \underline{94.2} \quad \underline{91.9} \quad \underline{90.4} \quad \underline{89.8}$

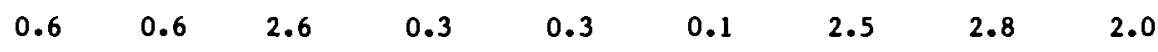

$\begin{array}{lllllllll}0.04 & 0.02 & 1.0 & 0.0 & 0.0 & 0.0 & 1.0 & 0.3 & 0.1\end{array}$

$\begin{array}{lllllllll}0.5 & 0.3 & 1.6 & 0.3 & 0.3 & 0.1 & 1.5 & 2.3 & 1.8\end{array}$

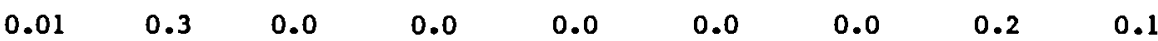

$\begin{array}{lllllllll}1.3 & 0.8 & 1.4 & 0.08 & 0.7 & 0.3 & 0.8 & 0.8 & 1.1\end{array}$

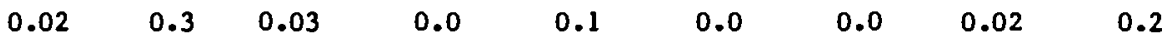

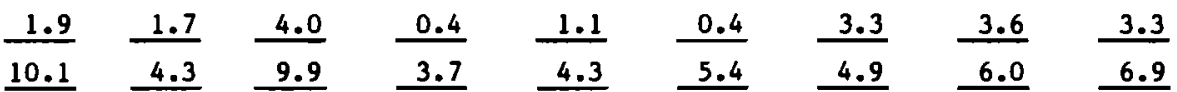


overall yleld of o1ls and tars in the PRU decreased considerably at the higher temperatures, so that the net environmental burden may actually be less. This can be seen graphically in Figure 42, which compares Tests GT-5 and GT-8.

It is apparent from the data shown in Table 18 and Figure 42 that higher operating temperatures, in addition to reducing the o1l yleld, also cause a sharp decline in the relative concentrations of heterocyclic and alkylsubstituted hydrocarbons in favor of unsubstituted aromatic hydrocarbons. Referring back to Figure 41 , it is seen that the overall yield of phenols, which is distributed between the aqueous and organic phases of condensate, declines by $97 \%$ to $99 \%$ when the gasification temperature is increased to $1510^{\circ} \mathrm{F}$ from $1390^{\circ} \mathrm{F}$.

There is also a relationship between the amount of steam present in the gasifier (steam input plus biomass feed moisture) and the nature of organic 1iquids produced. Figure 43 shows that the concentration of oxygenated oil components, as well as the overall phenols yield, declines as the steam-towood ratio is increased. Although more data points are needed in the range of 0.2 to 0.5 steam-to-wood ratio $(1 \mathrm{~b} / 1 \mathrm{~b})$ to confirm this, it appears that the yield of oxygen-containing oils (phenols in particular) reaches a steady minimum at a value of about $0.7 \mathrm{lb}$ steam/lb wood. The overall oil yield, however, seems to depend more on other factors, such as temperature, pressure, and feed material. Just as the results in Figure 42 showed the dependency of o11 yield on gasifler temperature, results in Figures 44 and 45 show how pressure and feed type affect the yleld and composition of organic 11quids found in the effluent. The production of all organic types except highly condensed aromatics ( $\mathrm{PAH}$ ) was much higher at the lower pressure. The overall yield of ofl decreased with increased pressure as well. Most strikingly, the yield of phenols decreased by a factor of 67 with the increase in pressure from 102 to 300 psig, and the yield of water-soluble organics, excluding phenols, likewise declined by a factor of about 7 . The results in Figure 45 show that the relative proportions of liquid product types did not change as much with varying feed material, although the total organic 11quid yield did. Whole tree chips, with a higher content of bark, leaves, and other nonwood pulp components, did produce more ofls than the maple wood chips.

There was a complete absence of oils in the condensate from Test GT-17. This test was performed with wetter (26.7\% molsture) wood. The reason for the 


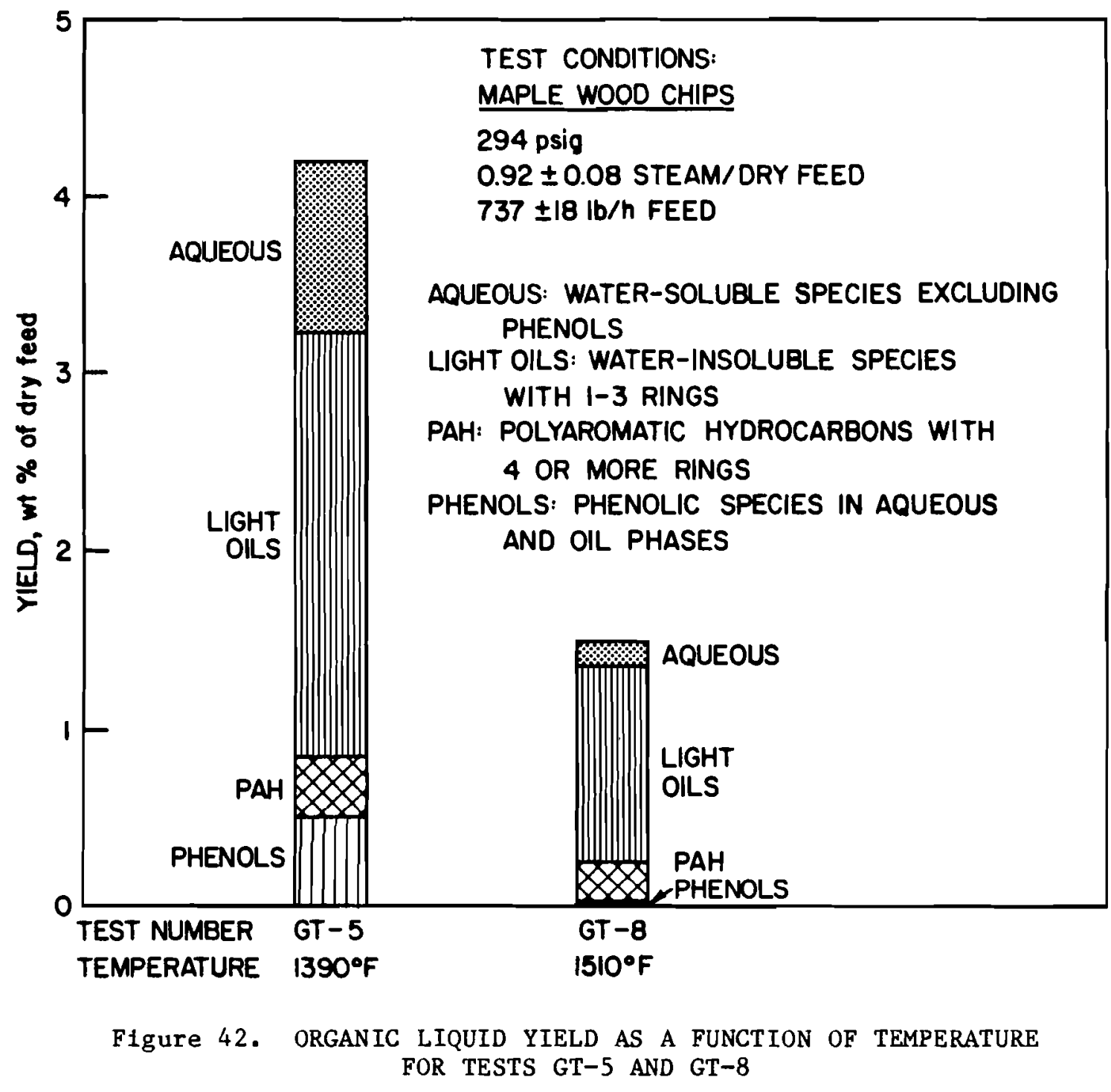




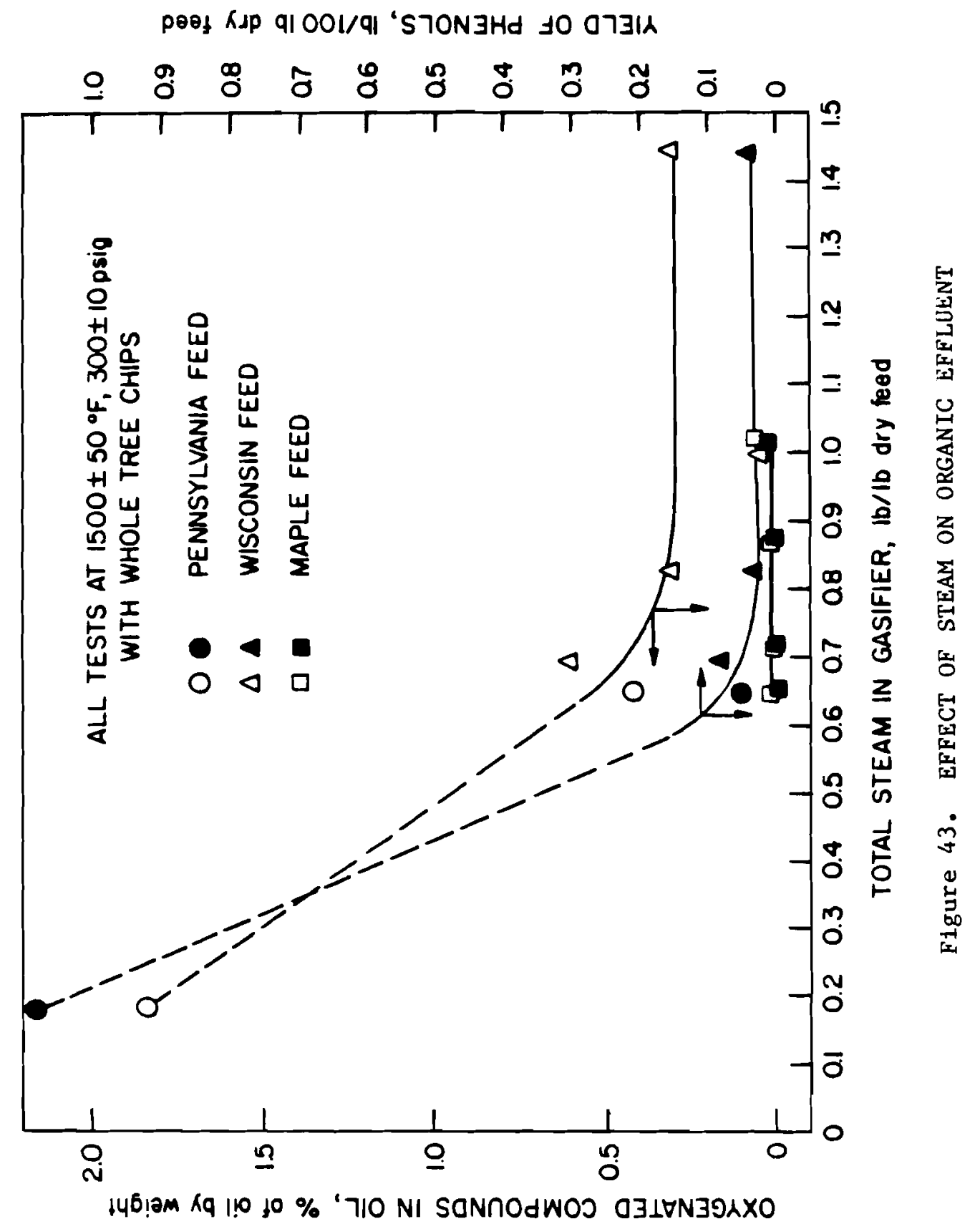




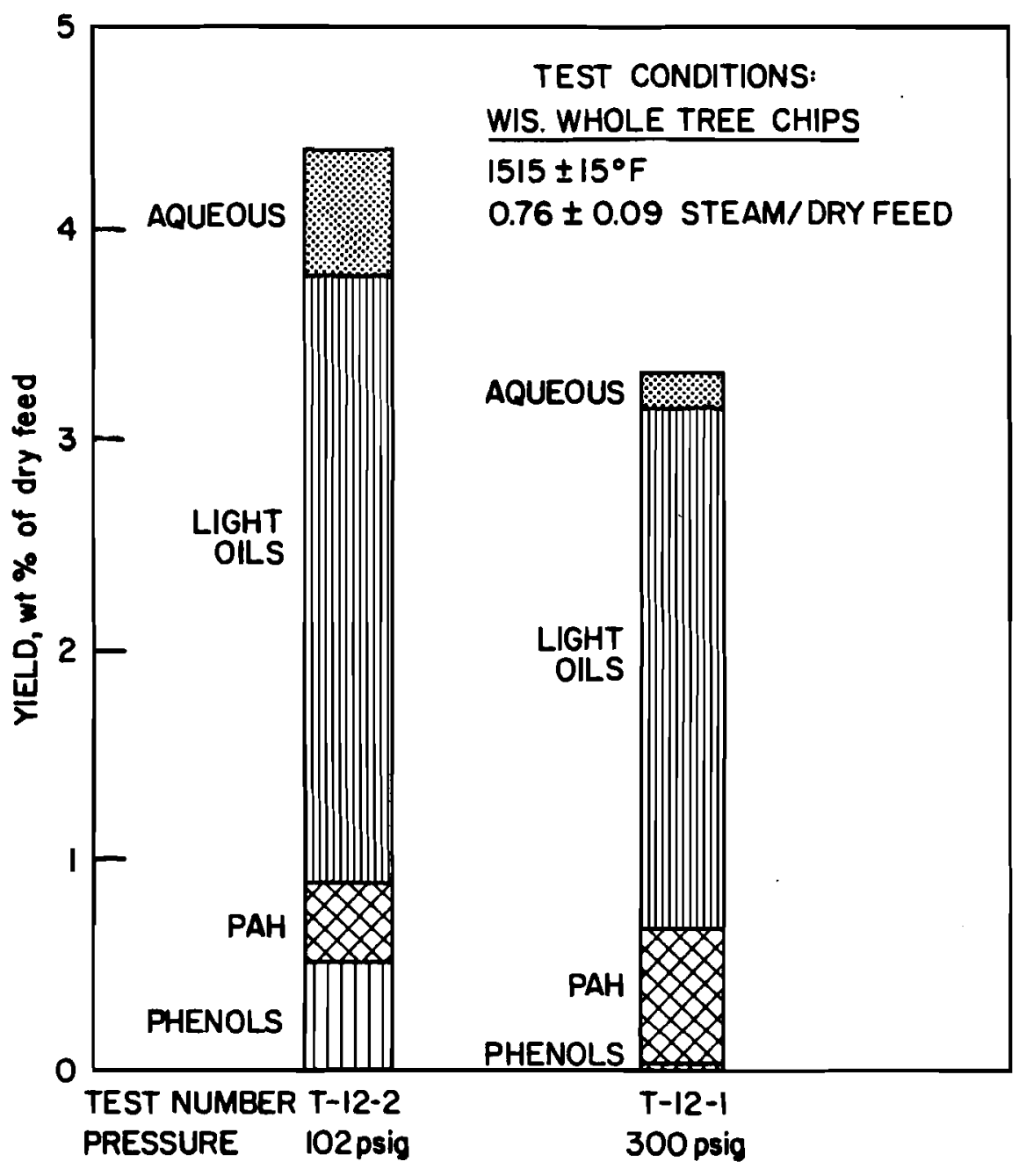

Figure 44. OIL YIELD AS A FUNCTION OF GASIFIER PRESSURE FOR TESTS T12-1 AND T12-2 


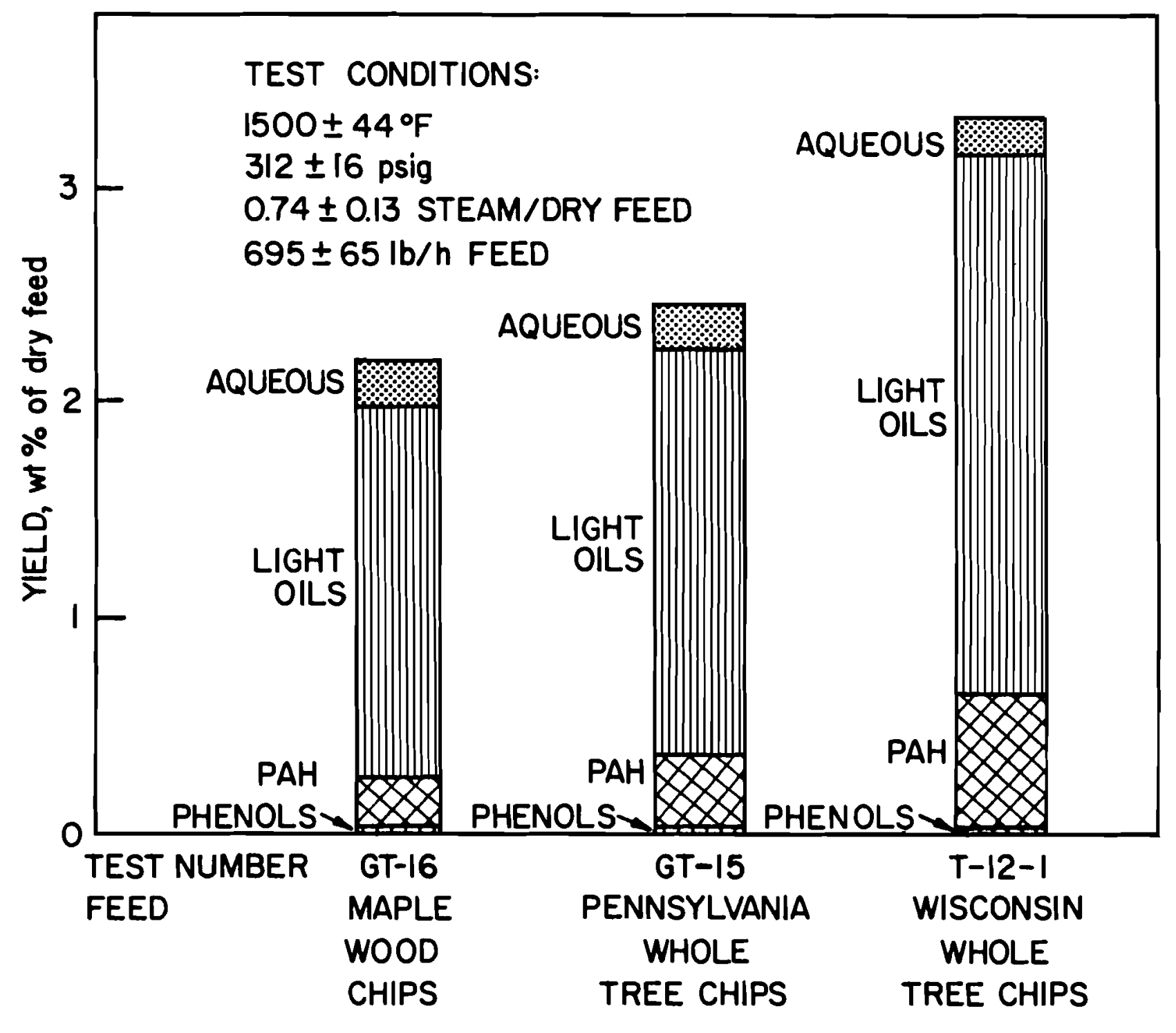

Figure 45. OIL YIELD AS A FUNCTION OF FEEDSTOCK FOR TESTS GT-15, GT-16, AND T12-1 
absence of olls is not clear, although it may be related to the high heat demand required to drive water from the incoming feed. A higher oxygen rate was required for combustion to supply this heat, and the combustion of ofls as well as some gaseous hydrocarbons may have occurred.

In conclusion, the analyzed data indicate that the production of organic 1iquid by-products can be minimized by increased temperature and pressure, but may also be somewhat related to feed type. From an environmental standpoint, conditions that favor lower concentrations of oxygenated, water-soluble components, particularly phenols, are desirable. These include higher temperature and pressure, and a steam-to-wood ratio above a minimum value which is in the neighborhood of 0.6 to $0.7 \mathrm{lb} / \mathrm{b}$. Dealkylation and dehydroxylation reactions, which bring about the decomposition of such undesirable by-products are favored by high hydrogen partial pressure and high temperature. Hydrogen in this case is supplied by the decomposition of steam through water-gas shift and steam-carbon reactions, as well as direct reactions of steam with organic liquid species in the gasifier. 


\section{CONCLUSIONS}

The Institute of Gas Technology (IGT) has conducted a pressurized, fluidized-bed blomass gasification process development program from laboratory-scale, bench-scale, and PRU process and equipment design phases to the construction and operation of a large-scale 12-TPD PRU system. The program culminated with the successful operation of the PRU over a range of process condition parameters and a successful 3-day steady-state operation of the pressurfzed fluidized-bed gasifler and auxiliary equipment.

The PRU support research and PRU tests were conducted with woody biomass, maple wood chips, and whole tree chips (a mixture of hard and soft wood species). A pressurized isokinetic probe, designed and constructed at IGT, coupled with a successfully operating wet-gas chromatograph significantly improved the data acquisition and analysis capability.

Test results (up to 3 days of steady-state operation) have shown that pressurized, fluidized-bed gasification at $300 \mathrm{psig}, 1500^{\circ} \mathrm{F}$, and feed rates up to $1030 \mathrm{lb} / \mathrm{h}$ of whole tree chips is a simple operation. Material and energy balances showed that the total carbon conversion is about $95 \%$ in the 1ongduration tests; this could be further increased by recycling the entrained char to the high-temperature region of the gasifler. The oxygen requirement at $1500^{\circ} \mathrm{F}$ was about $0.22 \mathrm{lb} / 1 \mathrm{~b}$ of feed material. Over the temperature range of $1400^{\circ}$ to $1800^{\circ} \mathrm{F}$ in the parameter-variation tests, the dry gas yield ranged from 14 to $19 \mathrm{SCF} / 1 \mathrm{~b}$ feed, and the gross caloriflc value of the fuel gas ranged from about 340 to $290 \mathrm{Btu} / \mathrm{SCF}$, respectively. The cold gas thermal efficiency at $1500^{\circ} \mathrm{F}$ and 300 psig operation was about $75 \%$.

Analyzed data of the small oll and tar fraction indicated that its production is dependent upon feedstock type and can be reduced by increased gasification temperature and pressure. The new information obtained in this program on the ofl and tar fraction is important environmentally and 1mpacts upon the scope and duty of process cleaning equipment. 


\section{ACKNOWLEDGMENTS}

Contributions by Dr. G. R. Rose and Dr. R. F. Zabransky on blomass devolitilization and Dr. S. P. Nand1 on char gasification are gratefully acknowledged. Dr. T. M. Knowlton and his staff assisted in the fluidization cold flow modeling studies. Mr. Gregory Kosowski's efforts in the construction and early operation of the PRU were vital to the success of this program. IGT acknowledges the helpful guldance provided by Mr. Mark Gerber and Mr. Gary Schiefelbein of PNL and Mr. Simon Frledrich of U.S. DOE. 
REFERENCES CITED

1. Institute of Gas Technology, "Development of Hydroconversion of Biomass to Synthetic Fuels," Final Technical Progress Keport, DOE Contract No. DE-AC02-80CS83004, 1981 .

2. Kosowski, G. M., Rose, G. R., Nandi, S. P. Singh, S. P., Onischak, M., Zabransky, R. F. and Babu, S. P., "Development of Biomass Gasification to Produce Substitute Fuels," Progress Report to the Thirteenth Biomass Thermochemical Conversion Contractors' Meeting, Arlington, VA., October 1981 .

3. Kosowski, G. M., Rose, G. R., Nandi, S. P., Singh, S. P., Unischak, M., Zabransky, R. F. and Babu, S. P., "Development of Biomass Gasification to Produce Substitute Fuels," Project 65058 Technical Progress Report for the period September 15 through December 15, 1981, Institute of Gas Technology, Chicago, March 1982.

4. Engstrom, S. and Lindman, N., "A New Synthesis Gas Process for Biomass and Peat," in Symposium Papers, Energy From Biomass and Wastes V, Sponsored by Institute of Gas Technology, in Orlando, Florida, January 1981.

5. Waldheim, L. and Rensfelt, E., "Methanol From Wood and Peat in Sweden," in Proceedings of Biomass-to-Methanol Specialists' Workshop, Solar Energy Research Institute, Golden, Colorado, March 3-5, 1982.

6. Sakoda, A., Sadakata, M., Koya, T., Furusawa, T. and Kuni1, D., "Gasification of Biomass in a Fluidized Bed," Chem. Eng. J. 22, 221-27 (1981).

7. Nandi, S. P. and Johnson, J., "Relation of Coal Properties to Gasification Reactivity and the Effect of Alkali Metal Catalysts on the Kinetics of Coal Gasification," Final Report GRI-78/0048, National Technical Information Service, Springfield, Virginia, November 1980.

8. Institute of Gas Technology, "Experimental Program for the Development of Peat Gasification," Interim Report No. 2, DUE Contract No. E(49-18)-2649, 1977.

9. Gran, H. S., Nandi, S. P. and Walker, Jr., P. L., "Nature of Porosity in American Coals," Fuel 51, 272 (1972).

10. Roy, T. N. and Nandi, S. P., "Pore Structure of Low Temperature Chars," Fue1 $49,346(1970)$.

11. Dubinin, M. M., "Porous Structure and Adsorption Properties of Active Carbons;" in Chemistry and Physics of Carbon, Vol. 2, 51-120, New York: Marcel Dekker, Inc., 1966. 


\section{APPENDIX A.}

Mechanical Design Drawings of the Process Research Unit Test System 


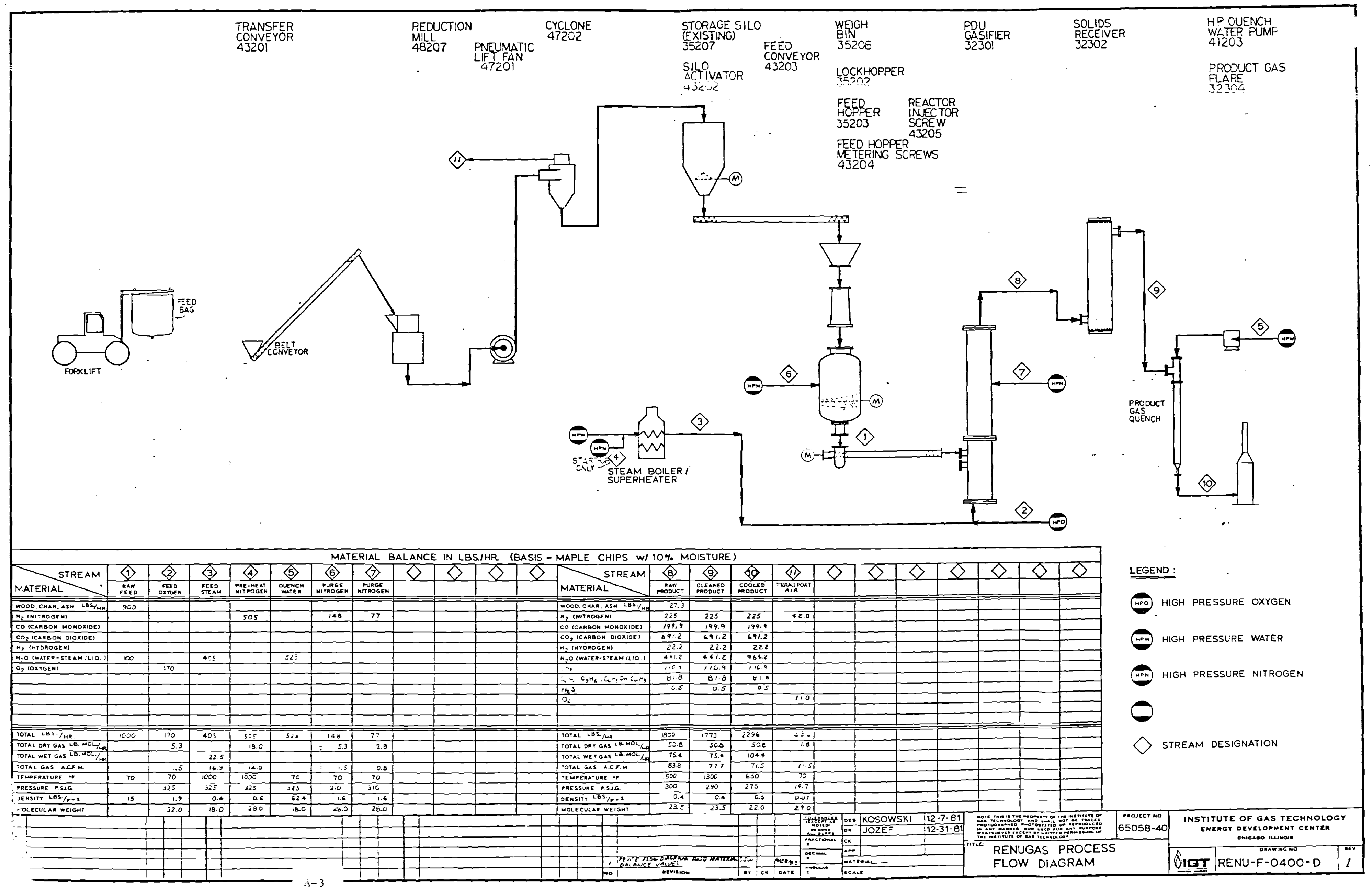




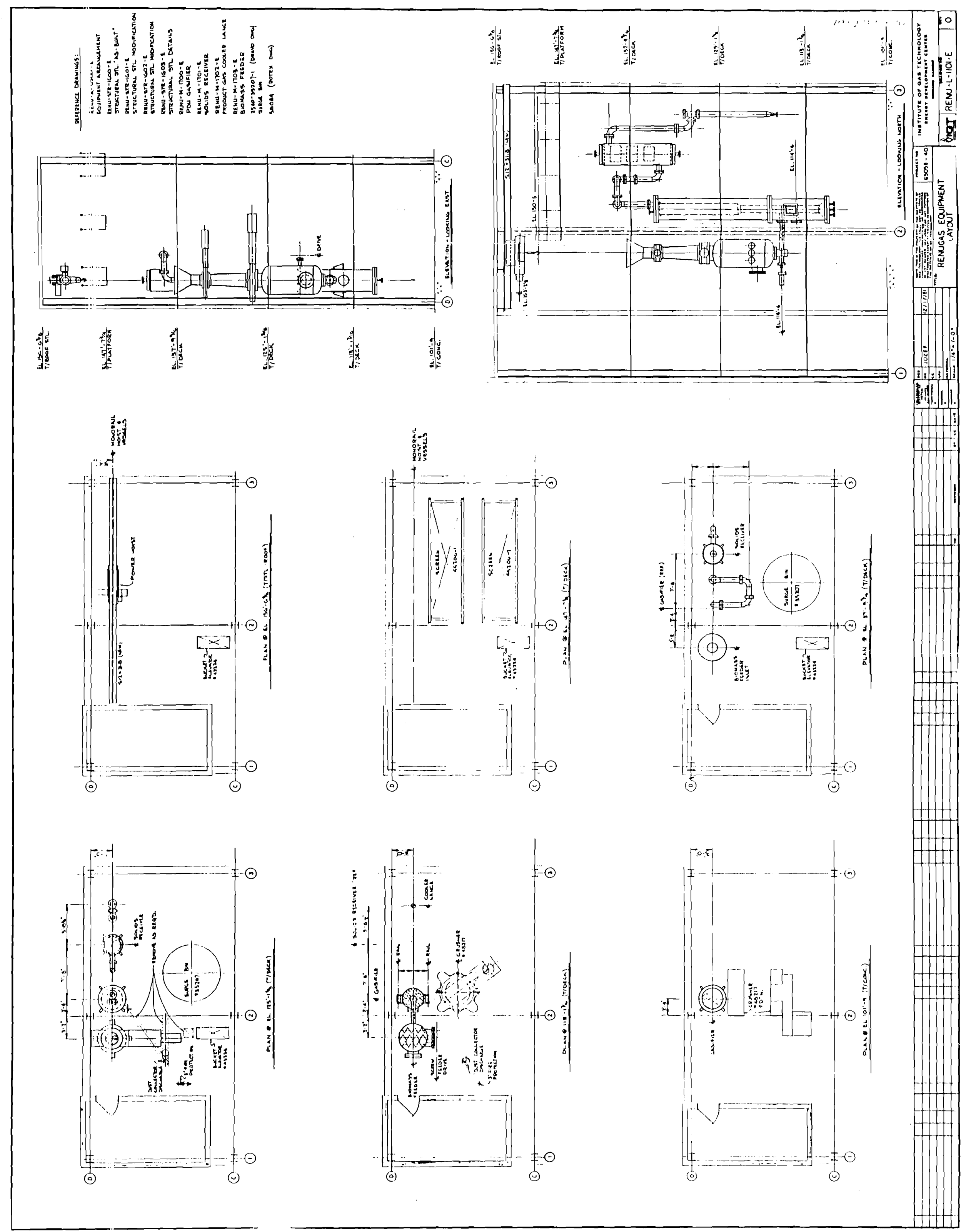




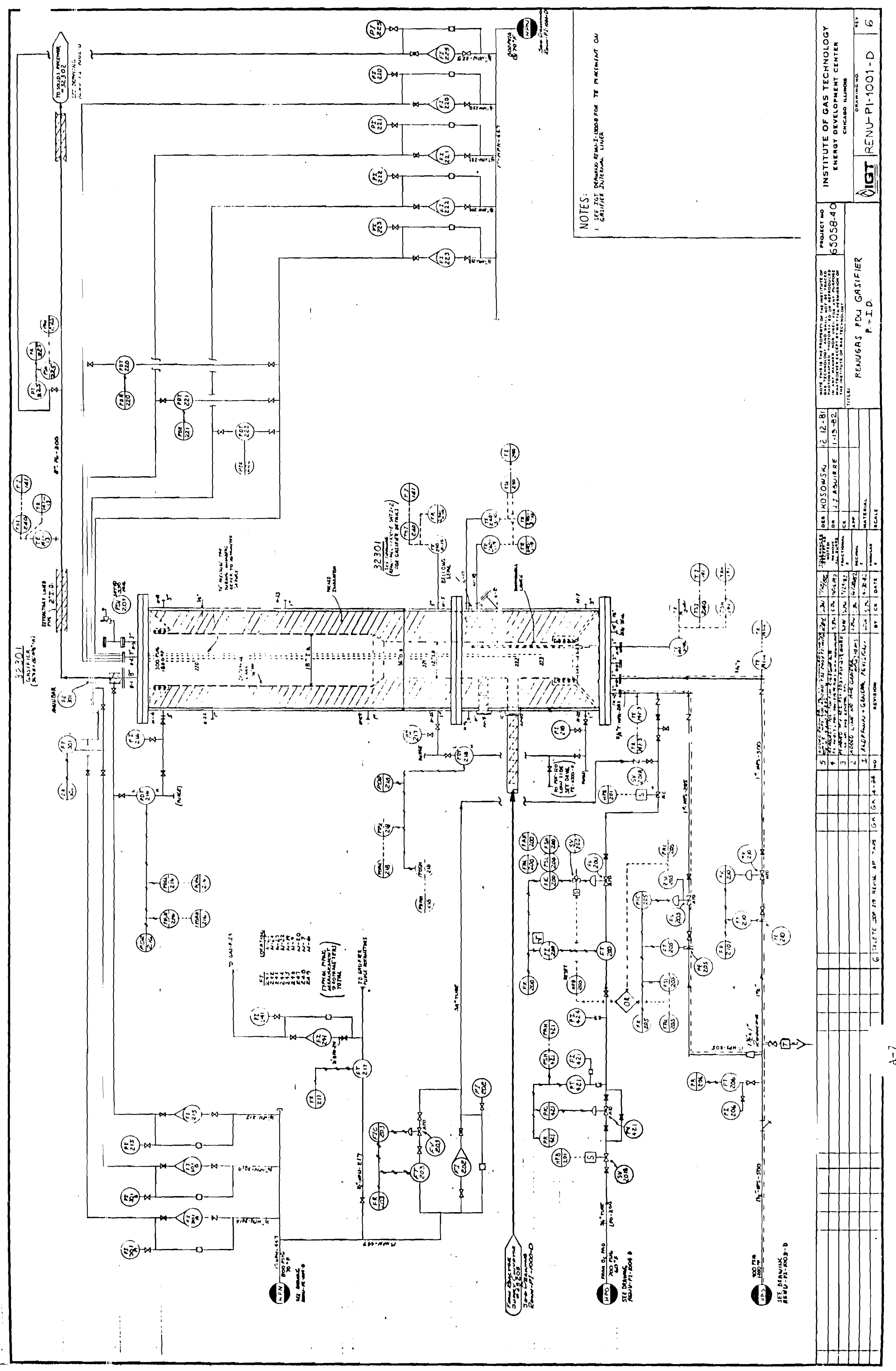




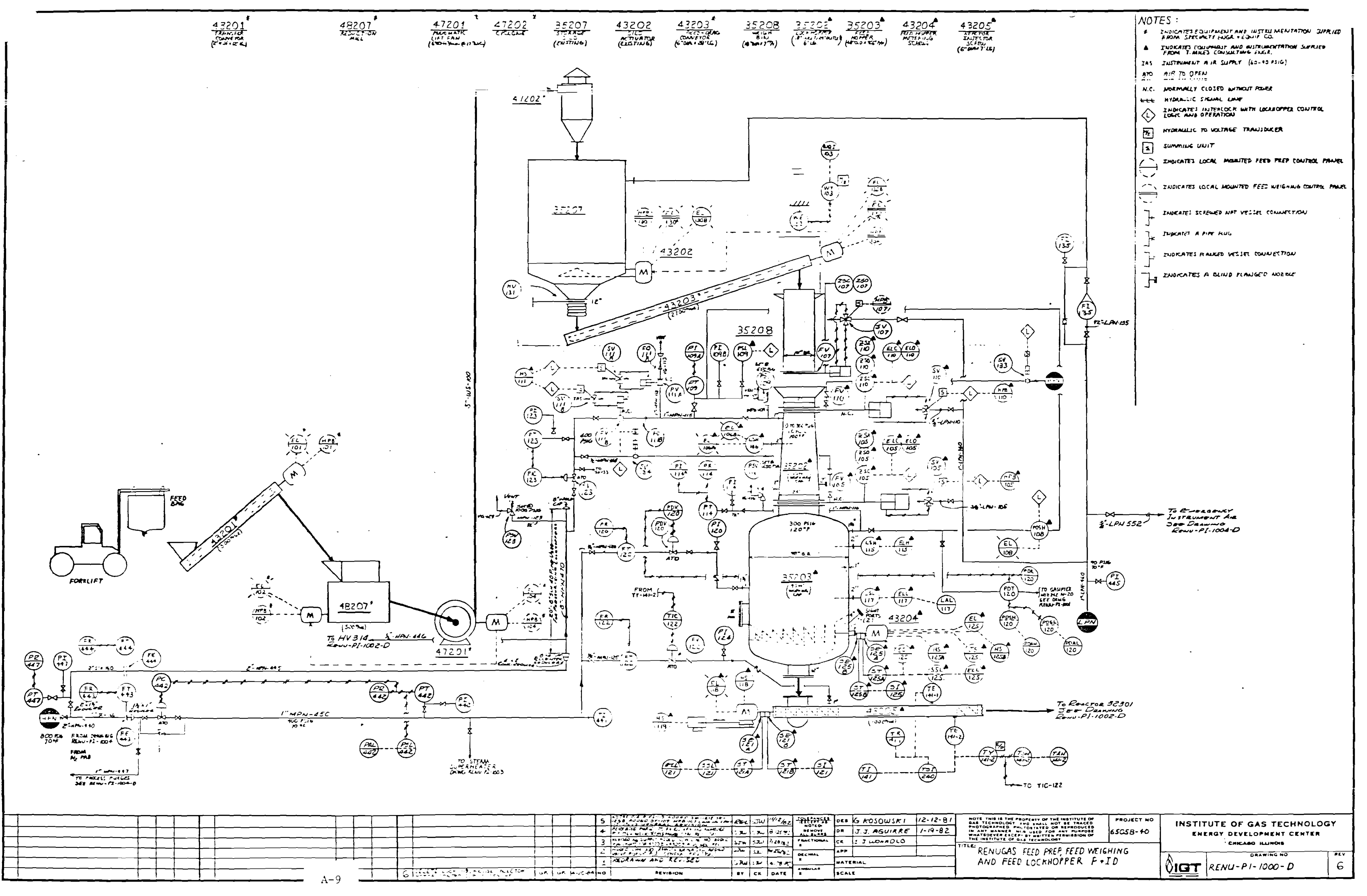




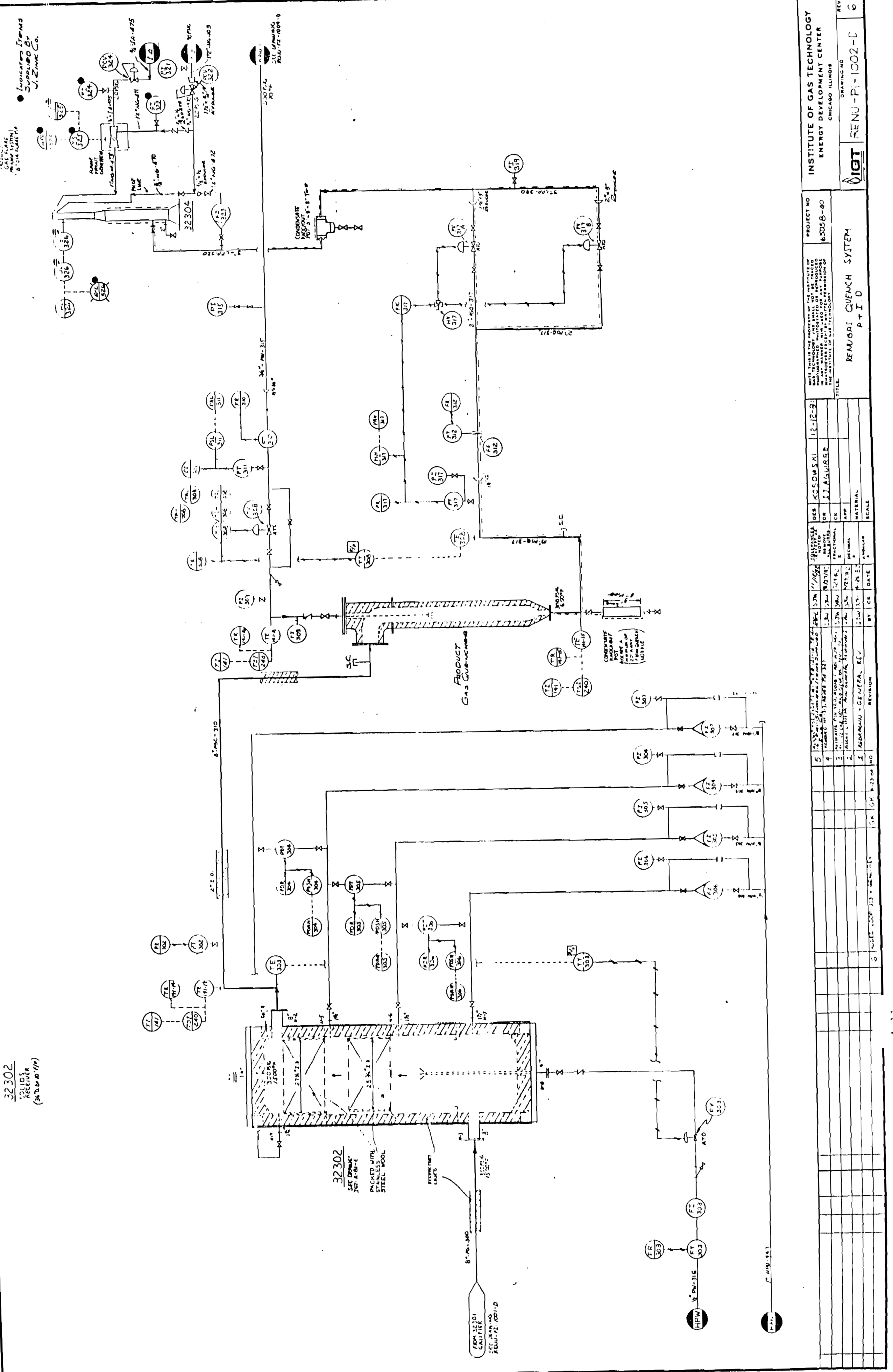




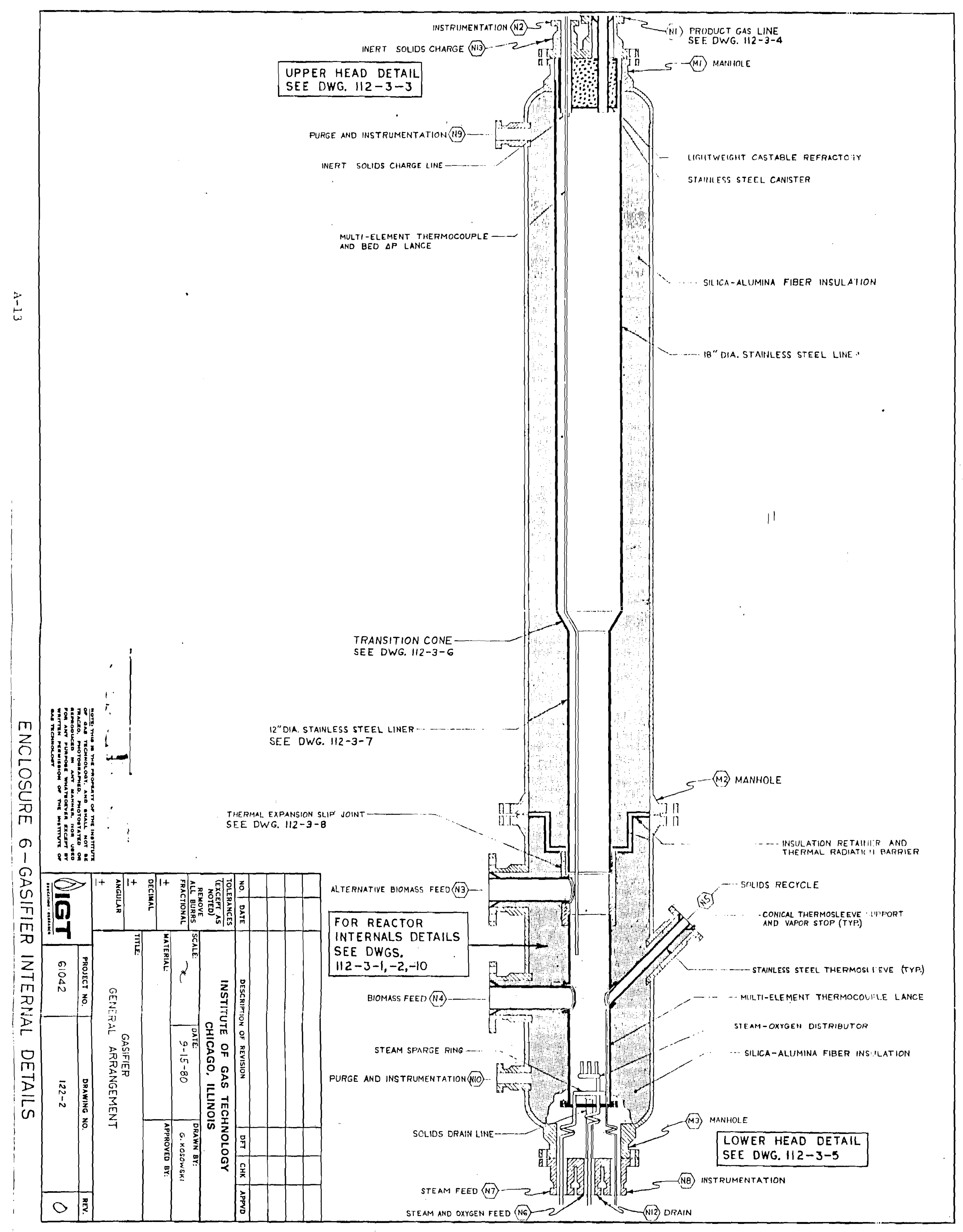


过

and

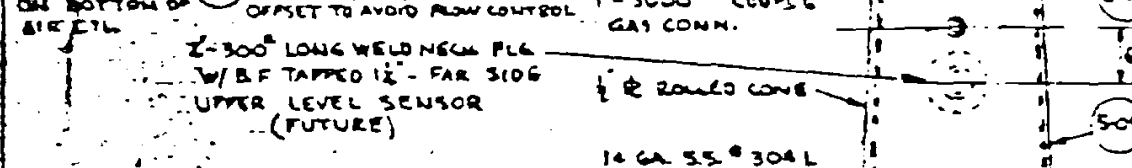

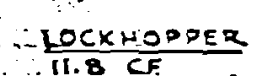

DNTED 160

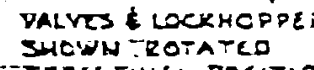

trot

trot

and

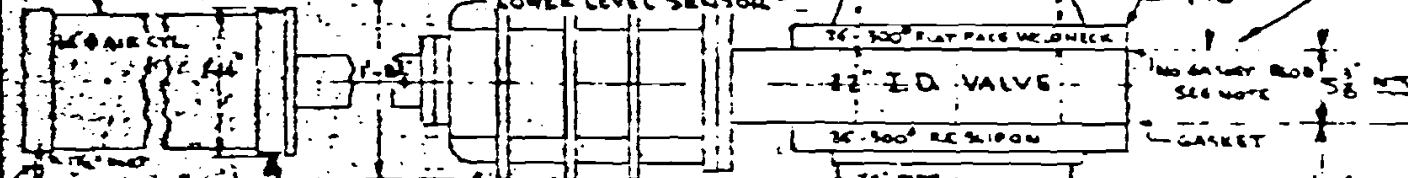

1.

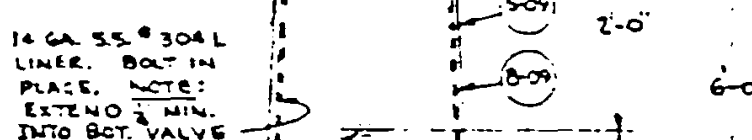

$+; \quad ; \quad 6$

$$
2
$$
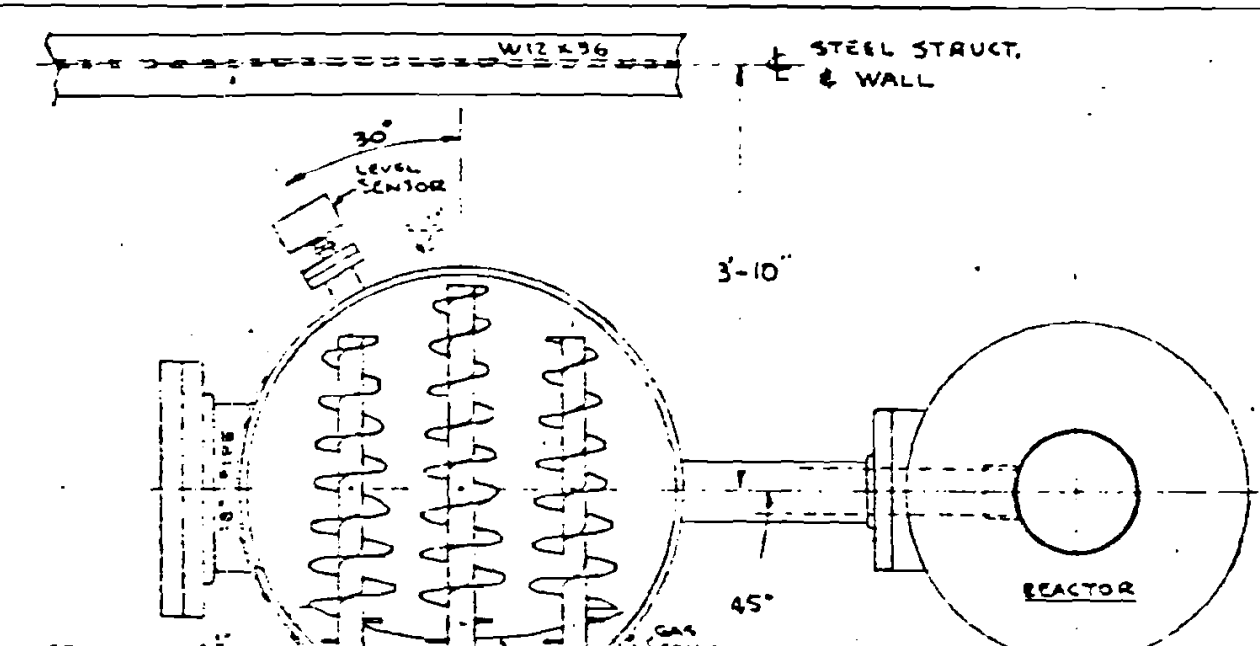
oi

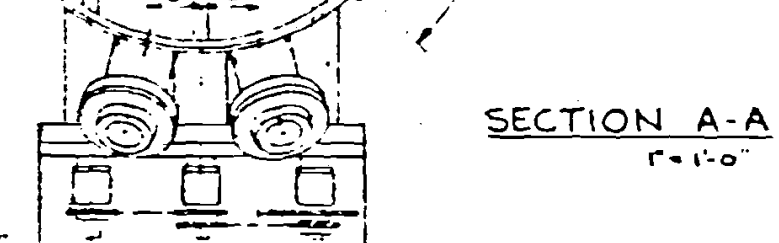

$\zeta^{E}$

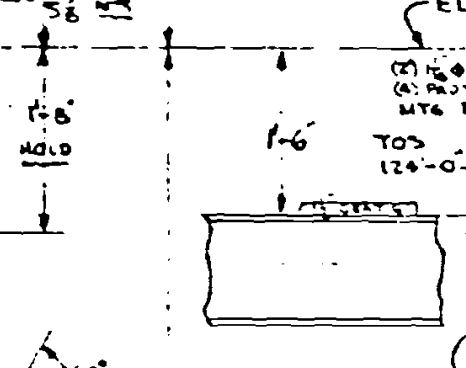

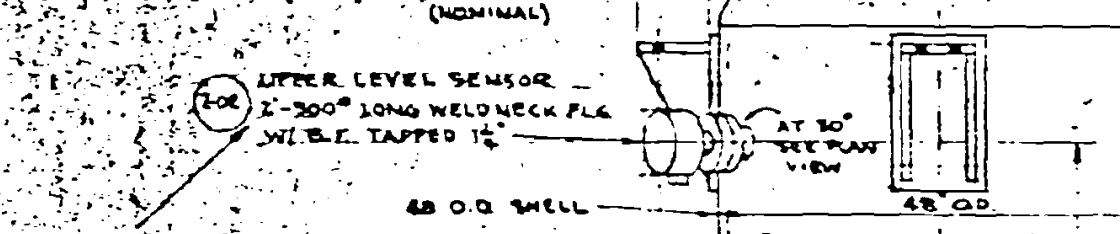

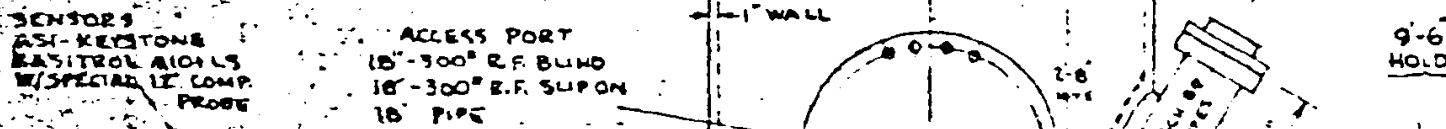

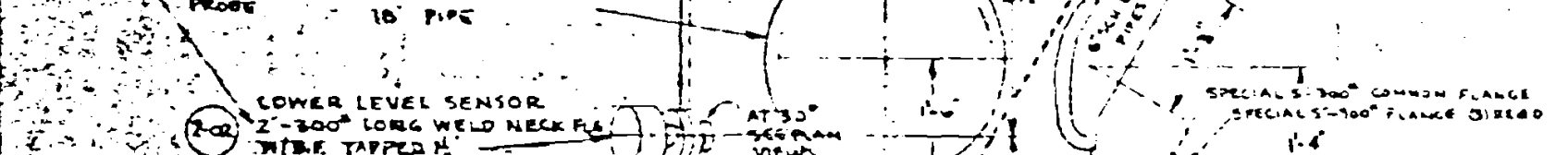

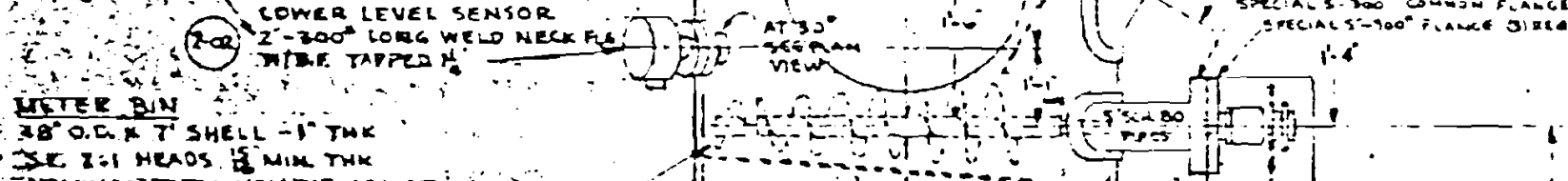

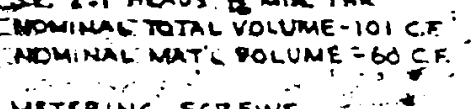

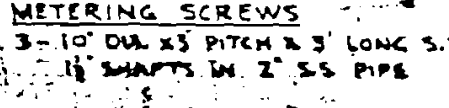

(1:
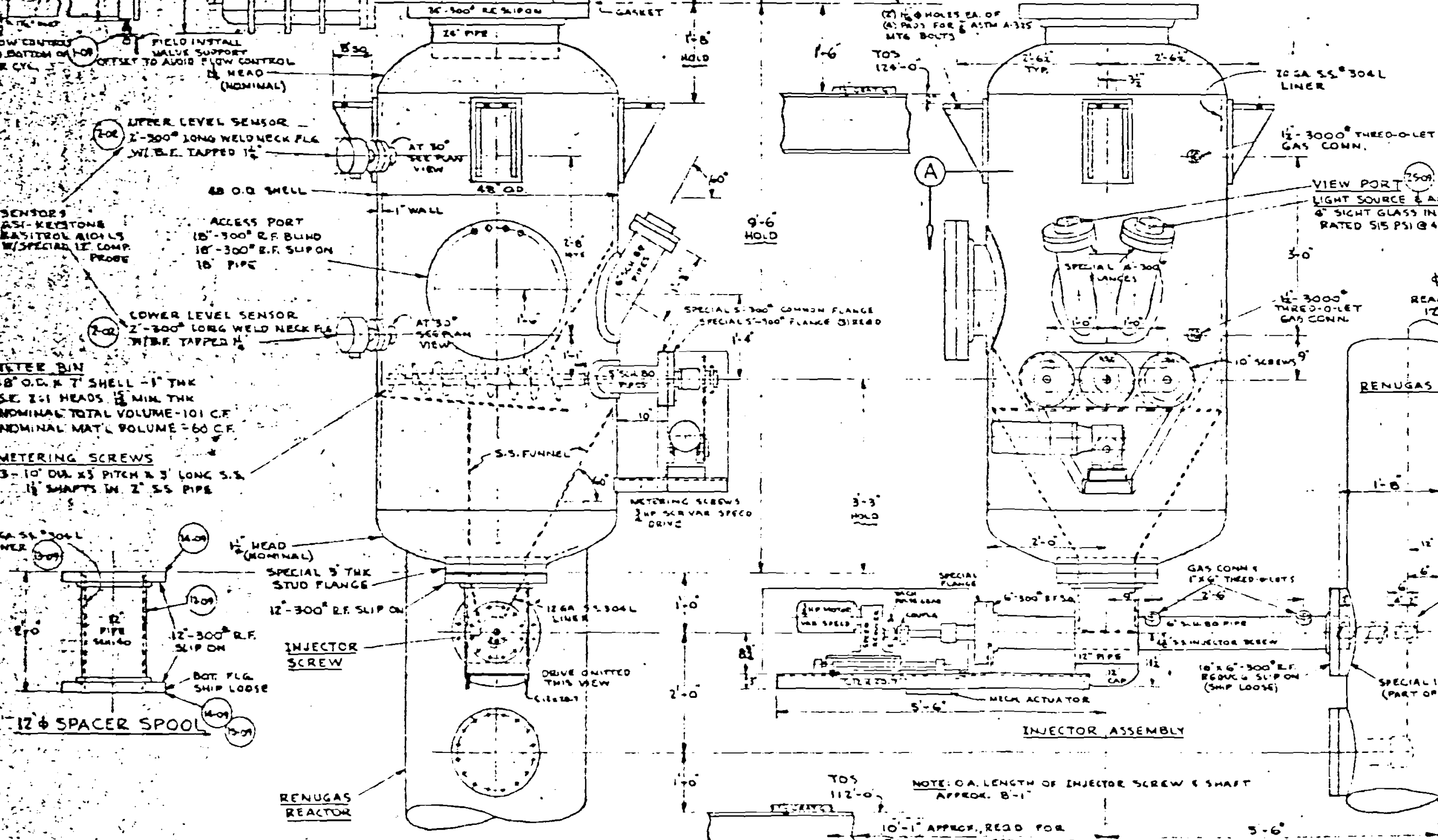

\section{Lr}
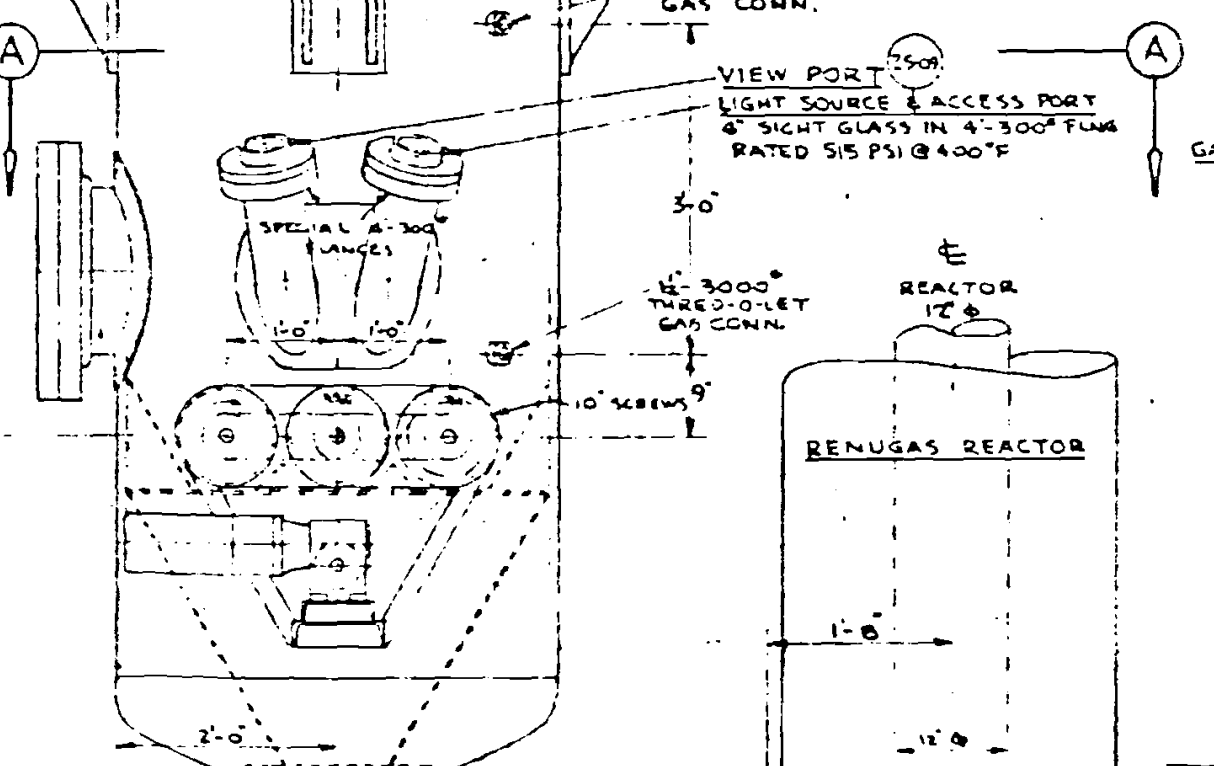

$1 \ldots 1-120$ $\frac{1}{101000}$ 1 ai

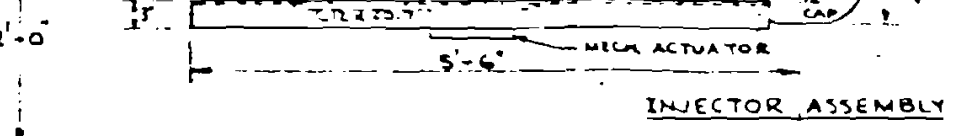

BererenCE Deawing

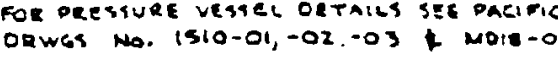

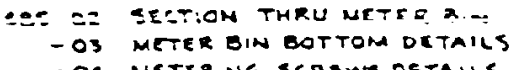

- os metreinc screms acaring assix D.
-

- og Misc. oetaiss

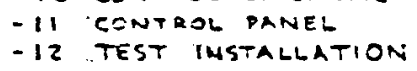

\section{NOTES}

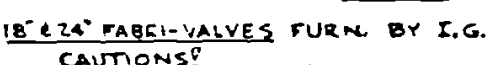

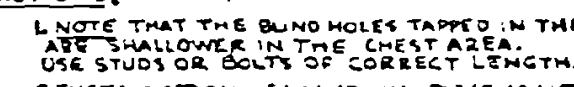

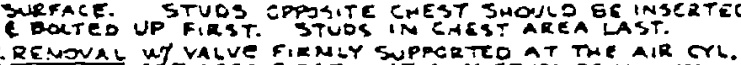

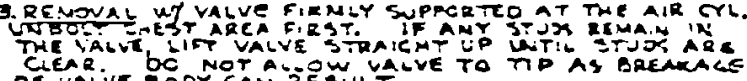
Metreing Sersws

Sccecw secese o pols Rem max.

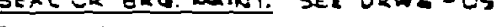

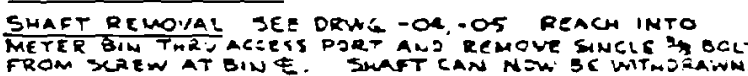
INSCTOR SSREW

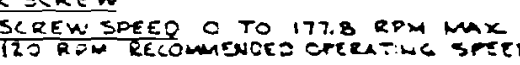

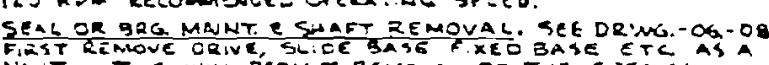

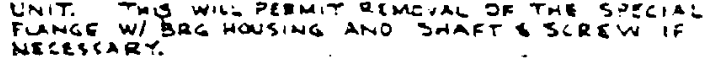

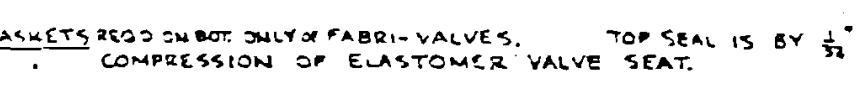

OESIGN TEMPERATURE - 150

DESIGN PRESSURE- 500 PSIC

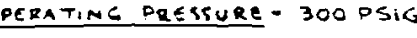

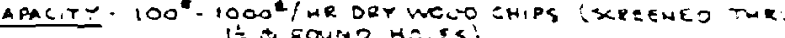

FOR MORE DETALIS- STE SENGRAL DESTLN SPECS,

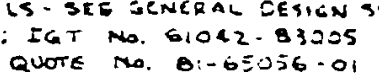

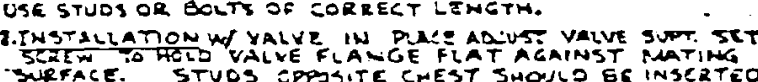

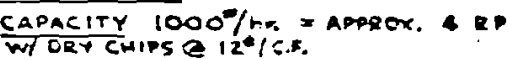

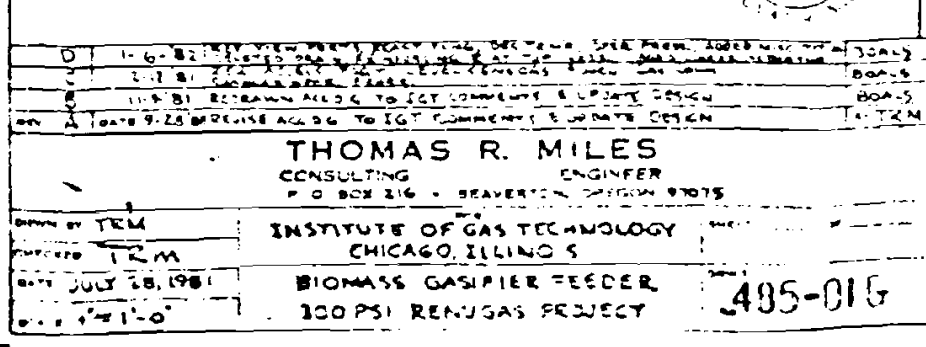




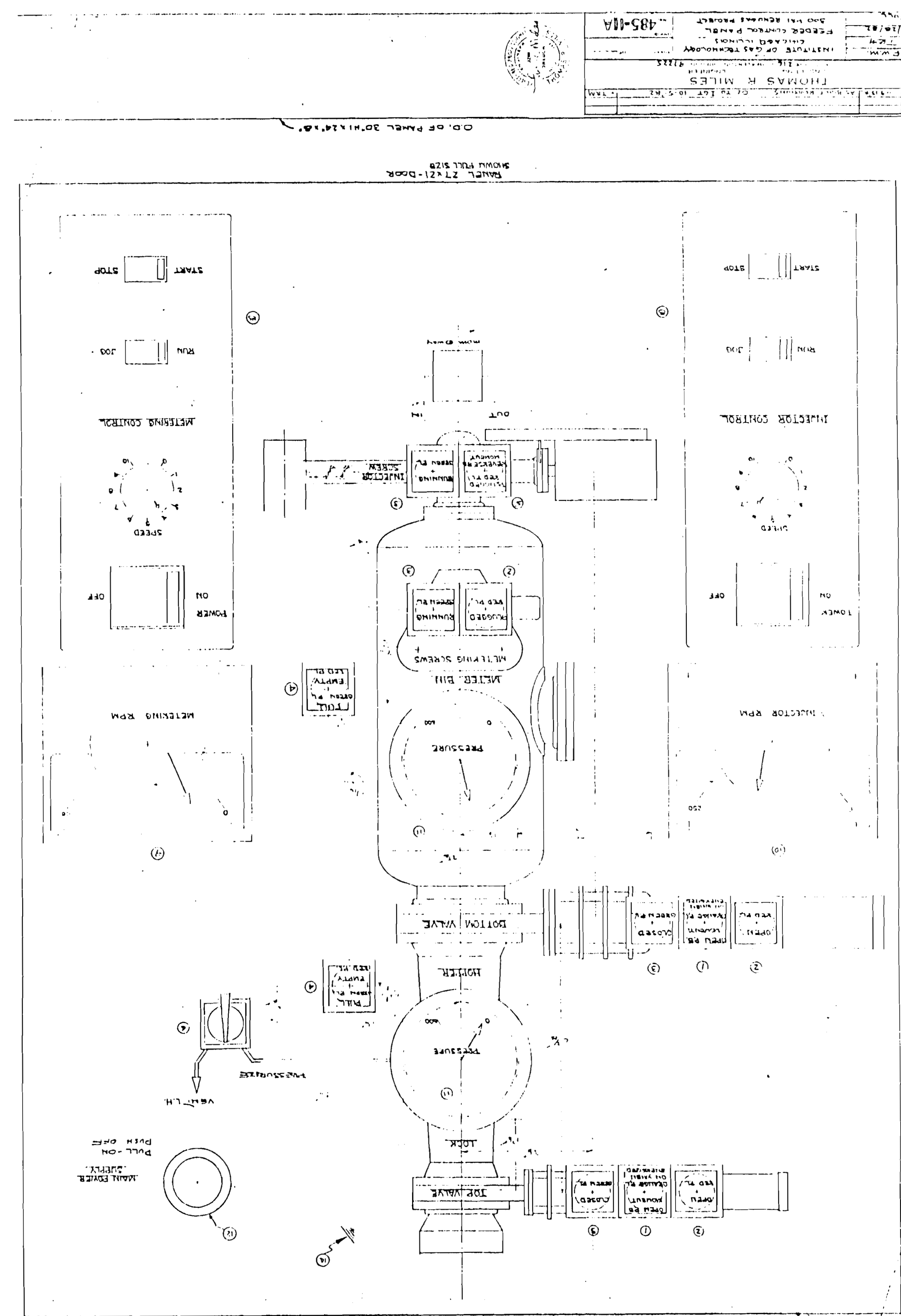

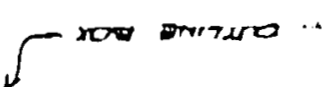




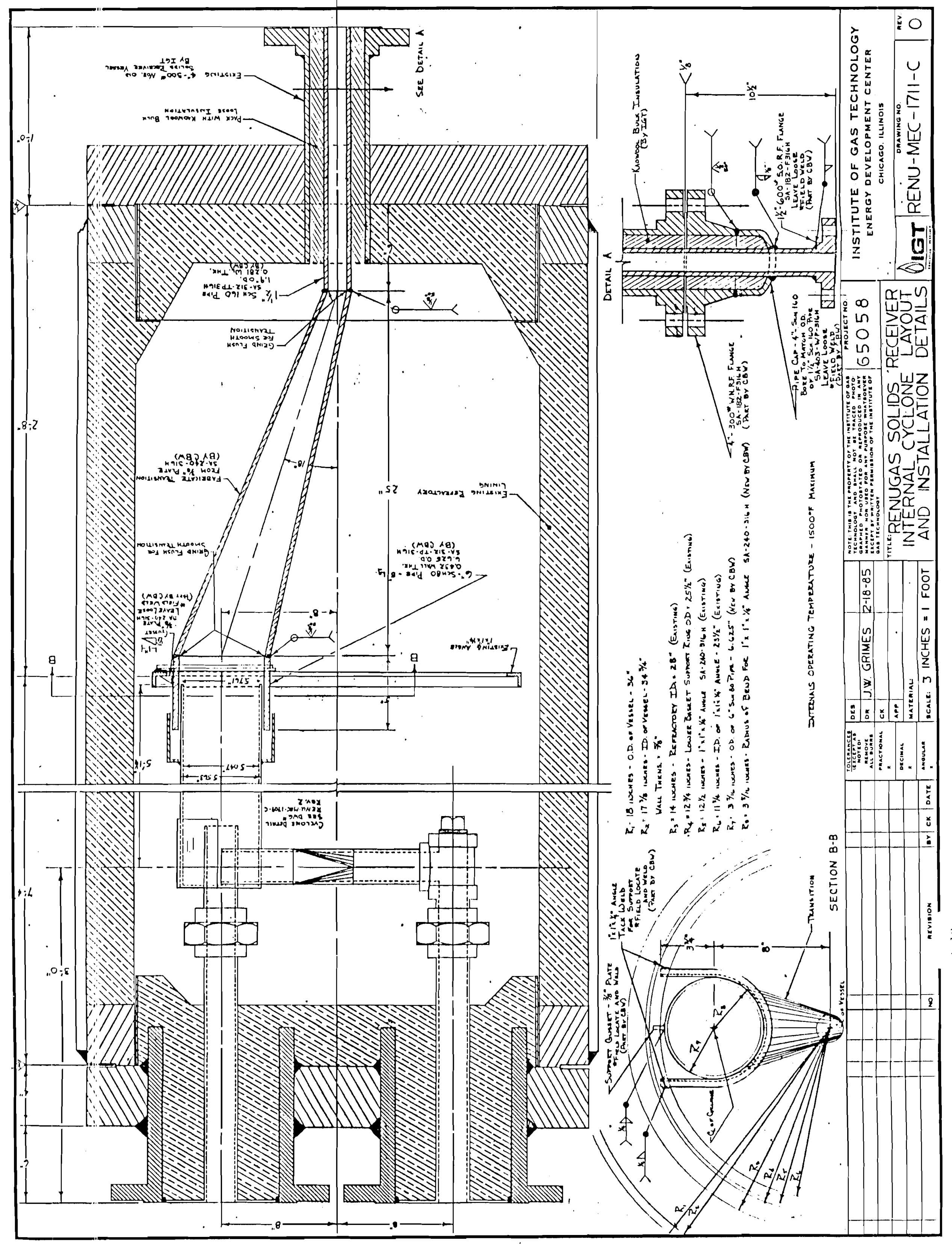


APPENDIX B.

Description of PRU Instrumentation 
Description of PRU Instrumentation

Successful PRU operation has been achieved with conventional, off-theshelf instruments specially adapted to measure and control the special PRU applications. Process variables monitored included: flow, pressure, temperature, and fluidized-bed density and level. These measurements are made at pressures up to $500 \mathrm{psig}$ and temperatures up to $1800^{\circ} \mathrm{F}$.

The control system utilizes a pneumatic system with basic feedback type control loops consisting of proportional and integral (PI) and proportional, integral, and derivative (PID) control modes to provide satisfactory control and performance. Pneumatic equipment offers easy maintenance and reliability.

For extended duration tests of several days, a 32 channel multipoint recorder and data logger was used for Interfacing with a Compaq Plus portable computer. The multipoint recorder has the feature of both trend recording and data logging. Normal trend recording can be interrupted to allow a digital data logging of all input signals, and then return to trend recording. The computer output bullt into the recorder/data logger makes possible the sending of process data to the personal computer. The raw data from the tests are permanently stored on floppy disks for easy retrleval. The PRU is also equipped with pneumatic/current $(P / I)$ transducers and computer interface to send RS-232 transmission into the Compaq personal computer for real-time data storage.

An important criteria for proper control of the RENUGAS fluidized-bed system is the accurate knowledge of bed density and total bed height. Conventional differential pressure techniques are used for both measurements. The density of the bed is determined by using the pressure difference between two fixed points of known elevation. Overall bed height is then measured using the total pressure drop over the entire reactor and the bed density measurement.

The differential pressure measurement is done by a sensor utilizing a diaphragm element connected to a force balance transmitter. The transmitter output signal ( 3 to $15 \mathrm{psig}$ ) is sent to a central control panel for recording. Because the reactor system contains suspended solids (fines), inert gas purges keep the pressure impulse lines free from plugging and solids accumulation. Proper purge control is required and regulated through the use of rotameters. 
Another use of differential pressure transmitters in the PRU is for gas and liquid flow metering. All liquid, gas, and steam flows are measured by conventional head-type meter installations where differential pressure is measured across a primary element to indicate flow. Industry standardized concentric sharp-edge orifice meter runs are used along with integral-type orifice meters specifically utilized for low flow rates. With head-type meters, pressure and temperature measurements are required for compensation to obtain mass flow for material balance data.

The biomass feed rate to the gasifier is monitored by a hydraulic load cell measuring feed batches dumped into the feed system described earlier. The weight of a single batch is approximately 100 pounds. The solids are dumped out of the lockhopper into the feed hopper, which contains a metering screw regulating the solids flow into the gasifier. Solids level in the metering feed hopper is monitored by a capacitance probe technique that provides a proportional level signal. Solids feed rate can be adjusted through a variable frequency $A C$ motor drive system controlling the metering screw's revolutions per minute. All controls for the lockhopper operation and screw speed control are located at the control panel.

Temperature measurement in the PRU is accomplished by conventional thermometry. Chromel-alumel (Type K) thermocouple junctions are used throughout the unit to monitor temperatures ranging up to $2000^{\circ} \mathrm{F}$. The elements are the ceramic-insulated, sheathed type and are 1/8-inch in diameter. Conax sealing glands have successfully been used as a device to route these thermocouples into the PRU pressurized vessels. The thermocouple extension wires used are of the same metallurgy.

Pressure in the PRU is maintained by regulating the flow of reactor offgas through a pressure letdown valve. The gas flowing through the letdown valve is hot and erosive in nature because of suspended fines. IGT has pioneered work in severe pressure letdown valves in prior coal gasification work (specifically the HYGAS and Steam-Iron Processes) by utilizing a commercially manufactured rotary choke valve constructed with tungsten-carbide discs with diamond lapped mating surfaces. The basic valve was modifled by IGT with features that significantly improved service life and control performance. The rotary discs consist of one fixed disc in the valve body while the other is rotated $90^{\circ}$ to open or block the flow. Actuation is 
provided by a spring/diaphragm operator receiving its pneumatic signal from a controller on the control panel.

$171 / R P P / 65058 \mathrm{APB}$ 
APPENDIX $C$.

PRU Experimental Procedures

C-1 


\section{Startup Procedure}

The startup of the PRU is a simple three part procedure. The first part consists of preheating the gasifier, containing about 800 pounds of inert solids, with hot nitrogen. During startup the steam superheater is employed to preheat the nftrogen to about $1100^{\circ} \mathrm{F}$. The temperature of the inert flutdized solids reaches about $550^{\circ} \mathrm{F}$ in about 4 hours. The system is slowly brought to the test pressure in this time. During heatup the nitrogen flow is regulated to maintain minimum fluidization conditions for the inert solids; a superficial gas velocity of at least $0.4 \mathrm{ft} / \mathrm{sec}$ at low startup pressure. The differential pressure between the balanced-pressure insulation zone and the liner is maintained at about 15 to $25 \mathrm{psi}$, which is within the specified mechanical design conditions.

The second part of the startup procedure consists of loading about 120 pounds of coconut shell charcoal (-1/8-inch size) into the live-bottom metering bin. Charcoal feed into the $550^{\circ} \mathrm{F}$ inert solids fluldized bed is Initiated at approximately $60 \mathrm{1b} / \mathrm{h}$. The charcoal is ignited by slowly adding oxygen to the fluidizing nitrogen stream. The fluldized-bed temperature rises uniformly to the gasification test temperature and is maintained there for about 2 hours. Because the charcoal has little or no volatile matter, there is no chance for ofl or tar deposttion in the cooler downstream section of the PRU system. In these 2 hours of charcoal heatup operation the downstream piping and vessels gradually heat up. The heatup procedure is considered complete and the reactor is ready for gasifylng woody biomass when the refractory piping at the downstream water quench reaches $500^{\circ} \mathrm{F}$.

The third and final phase of the startup procedure involves initiating wood feed at $300 \mathrm{lb} / \mathrm{h}$ and the flow rates of steam and purge nitrogen are established switching from nitrogen to steam flow to the superheater. At this point the oxygen flow is regulated to maintain the predetermined gasification test temperature for about an hour, before increasing the wood feed to the selected test feed rate. The elapsed time from cold start to flow stabilization and beginning of wood gasification steady state is about 10 to 12 hours.

The PRU operating procedures for all the tests were the same. Three tests were conducted with low steam-to-wood ratios (Tests GT-14, GT-15, and GT-17) as a part of the parametric studies with minimal deviations. 
Modifications for low flow measurements and consequent instrument range adjustments were made for these tests in order to meet the objectives of the tests.

Shutdown Procedure

Shutdown operations for the PRU system required about 6 hours from the time the wood feed, steam, and oxygen (or air) were stopped. Most of the time was required for depressurization and reduction of the bed temperature to below $500^{\circ} \mathrm{F}$. During this time the superheater was slowly cooled with nitrogen, which also flows through the gasifier. This slow cooling procedure assured protection of the PRU equipment. Rapid cool down procedures could be possible if bypass piping and hot service valves were installed at various locations. In either case, the overall shutdown procedure was very simple. When the fluidized-bed temperature was below $500^{\circ} \mathrm{F}$, the nitrogen flows were stopped and the inputs to the gasifier were blocked off while the valves at the pressure letdown station were locked open. The entire system then cooled down in this mode.

$171 / \mathrm{RPP} / 65058 \mathrm{ApC}$ 
APPENDIX D.

Description of Gas, Liquids, and Solids Sampling System 
The sampling of gases, liquids, and solids from the product gas stream is achieved by the operation of two sampling systems: the gas analyzer system (GAS) and the isokinetic sampling system (ISS). Both streams are withdrawn at a common sampling point close to the gasifier exit. Each sample probe consists of a 1/4-inch 316 SS tube extending into the center of the 2-inch-IU, 8-inch-OD refractory-lined product gas pipe. Both sample tubes are welded to a 1/2-inch NPT pipe cap on the end of a position-adjustable pipe assembly. A cut-away view of the pipe showing the sampling probe arrangement is illustrated in Figure $\mathrm{D}-1$ and the overall sampling system is shown schematically in Figure D-2.

The particulate and condensate ISS probe faces into the center of the flowing gas stream, and withdraws approximately $1 \%$ of the total gas flow at isokinetic conditions. The leading edge of the open ended tube is tapered outward to reduce impingement.

The product gas sample 1s drawn through the ISS probe at a velocity approximately equal to the estimated gas velocity in the product gas line. The product gas velocity is estimated from the gasifier input rates and the feed conversion to gaseous products. Using the steam content measured by the on-line GC, a dry gas flow rate for the sample is calculated and maintained at the dry gas meter. At the proper operating conditions the ISS probe gas sample flow rate is about $1 \%$ to $1.5 \%$ of the total product gas flow rate. The ISS is operated for 1 hour during the steady operating period. The ISS withdraws a representative sample of product gas, which passes through a preheated $\left(450^{\circ} \mathrm{F}\right)$ filter canister housing containing a glass filter element. The entrained particles are trapped here and the clean gas flows through a water-cooled condenser. The condensate is collected in a 1-gallon $316 \mathrm{SS}$ pressure vessel and the cooled stream then passes into a similar pressure vessel submerged in an ice-water bath. The gas stream is then reduced in pressure by a pneumatically operated $1 / 4-$ inch regulating valve. A final sintered stainless steel filter removes the remaining entrained particles and the sampled gas flow is measured with a dry test meter. The collected liquid and solid samples are weighed and analyzed, yielding average values for the solids entrainment rate and the condensate water and oil rate during the steady gasification period. 


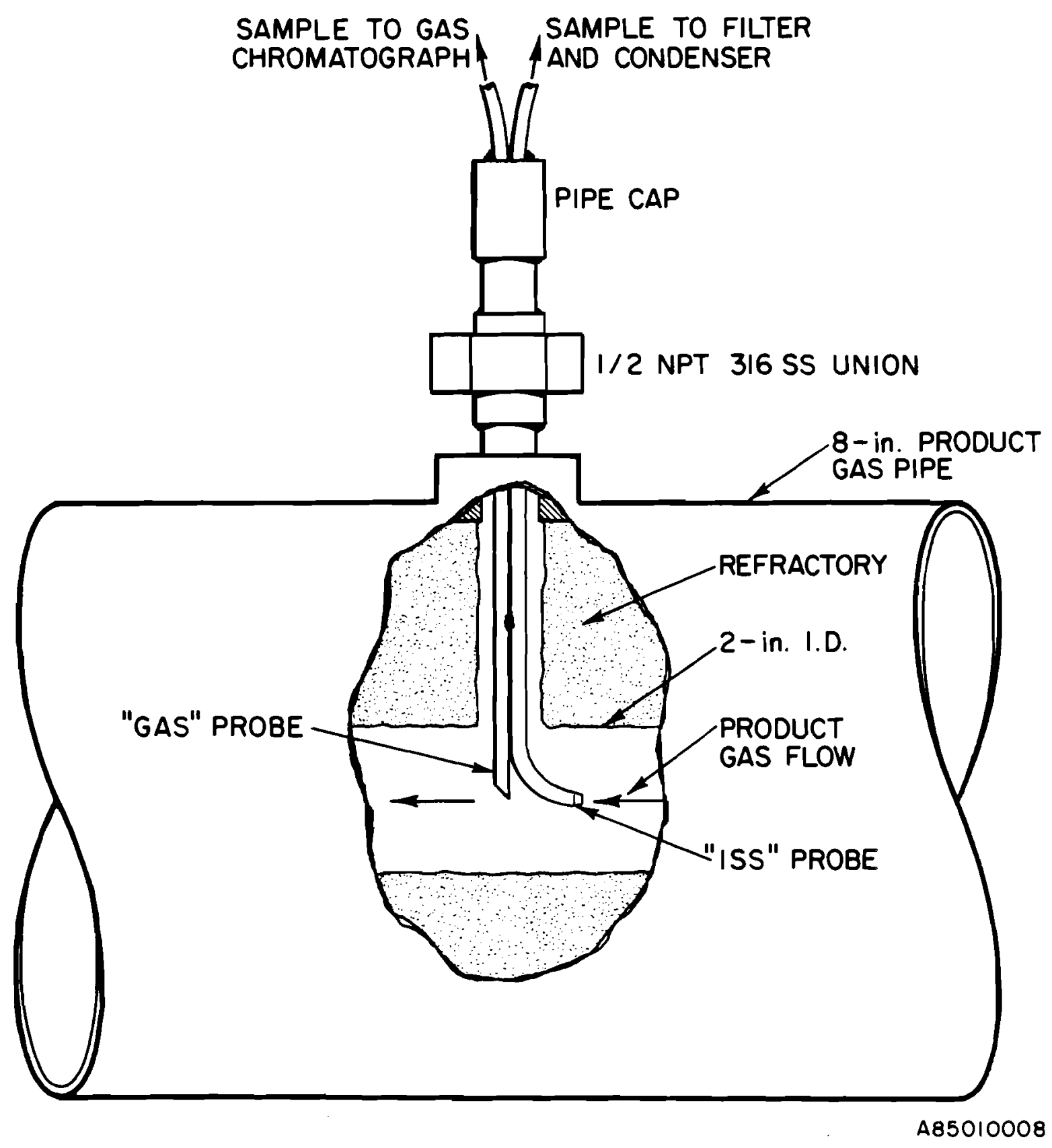

Figure D-1. DUAL SAMPLE PROBE 


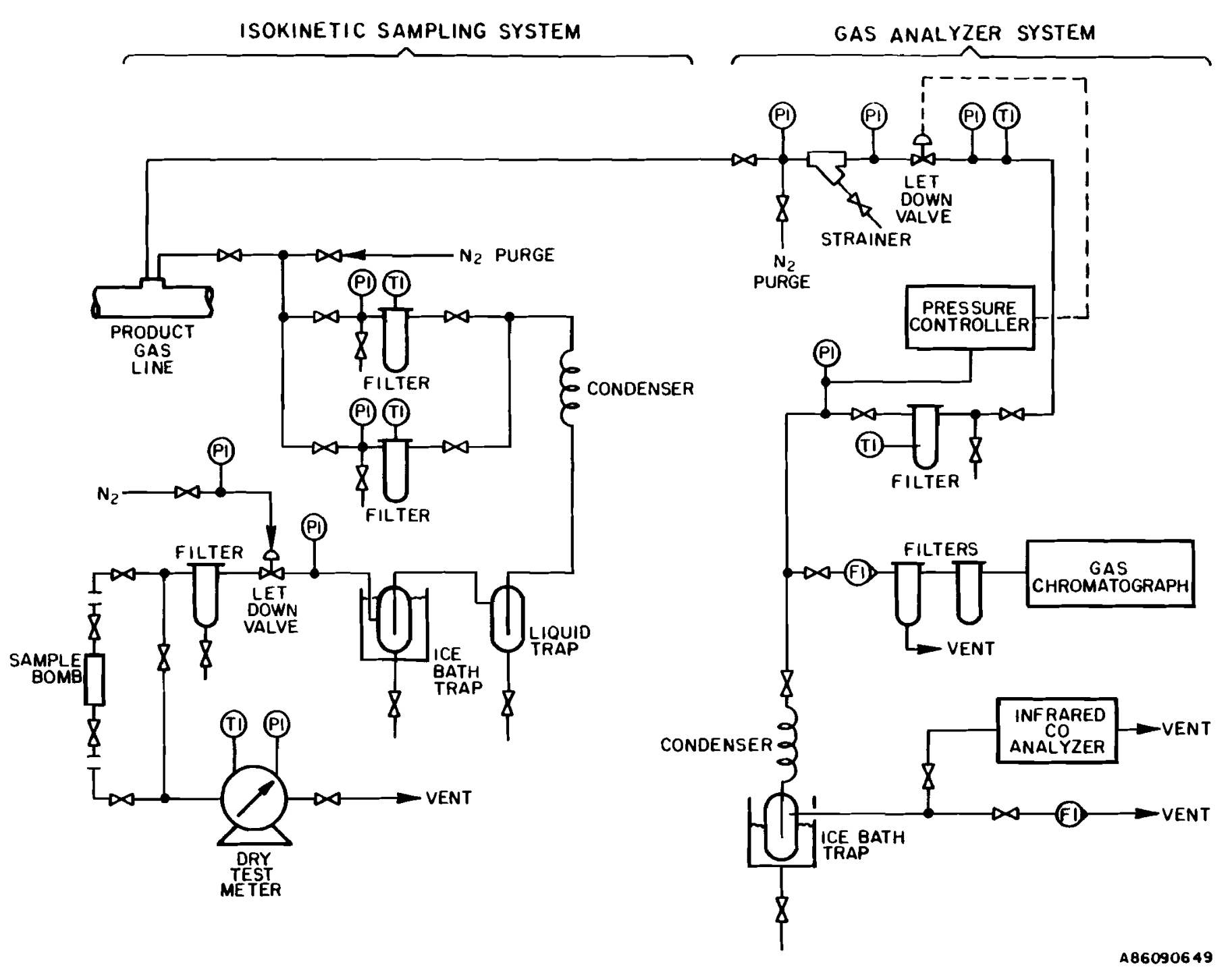

Figure D-2. SAMPLE SYSTEM FOK GASES, LIQUIDS, AND SOLIDS 
The ISS and associated instruments are installed close to the sampling point. The entire tubing length from sample inlet to gas flow meter is about 16 feet, which includes a 4-foot coil inside the water condenser. Except for the sample tube inside the product gas line and the line downstream of the ice-water bath, larger 3/8-inch and 1/2-inch 316 stainless steel tubing is used to avoid plugging by tars and particulates.

The GAS probe faces away from the direction of gas flow to minimize solids withdrawal. The tube size increases to $1 / 2-1$ nch as it leaves the probe and the pressure is reduced to $15 \mathrm{psig}$ by use of a pneumatically-controlled 1/4-inch regulating valve. From this point, the sample lines are electrically heated to prevent condensation. The sample enters a canister type filter housing containing a l-micron fibrous glass filter element to trap almost all of the particulates. The canister is also electrically heated to $300^{\circ} \mathrm{F}$ to ensure that no water condenses. The stream goes directly to a bypass filter Inside a heated cabinet and then passes through a final sintered metal filter before entering the on-line gas chromatograph (GC). The GC automatically analyzes $\mathrm{H}_{2}, \mathrm{CO}_{2}, \mathrm{Ar} / \mathrm{O}_{2}, \mathrm{CH}_{4}, \mathrm{CO}$, and $\mathrm{H}_{2} \mathrm{O}$ once every 12 minutes.

The gas chromatograph and instruments were installed as close as possible to the sampling point to minimize the lag time and the potential for cold spots and tar bulld-up.

The gas analysis instruments are calibrated with a standard gas mixture before and after each test. In addition, the GC Is calibrated on a dry basis every 90 minutes during a test. A wet-gas calibration of the GC is done before each test by bubbling dry calibration gas through an electrically heated bubbler filled with distilled water.

During the steady-state operation, samples of cool, dry, clean gas are also taken in stainless steel sample bombs for a confirmatory analysis by a laboratory gas chromatograph that analyzes for additional hydrocarbon species.

An "Annubar" pressure differentlal flow meter installed in the gasifier exit line, and a standard orifice meter in the product gas line measure the product gases before and after quenching. A purge-nitrogen balance is routinely made to verify the product gas flow rate. In addition, the PRU operating procedure can also use a metered injected argon tracer gas to serve as a double check on the raw gas production rate. 
Over 19 adiabatic biomass gasification tests have been conducted in the PRU at feed rates of up to $1430 \mathrm{lb} / \mathrm{ft}^{2}-\mathrm{h}$ of biomass at $300 \mathrm{psig}$ and $1500^{\circ} \mathrm{F}$. The large-scale operation, combined with the use of the on-line isokinetic sampling system, the on-line wet-GC, and off-line gas and liquid sample analyses ensures the collection of the field of data necessary to prepare accurate material and energy balances for process evaluation and scale-up. $171 / \mathrm{RPP} / 65058 \mathrm{APA}$ 
APPENDIX E.

Summary of Material and Energy Balances

for Individual Gasification Tests

E-1 
Summary of Material and Energy Balances for Individual Gasification Tests

Each test was conducted at predetermined gasification conditions to develop process scale-up information. Tests were conducted for steady-state periods of approximately 4 hours except for the long duration tests which were conducted for steady-state periods of up to 3 days.

Determination of steady-state operation is defined by the following:

1. Changes or deviations in the wood feed rate are about: $\pm 5 \%-10 \%$

2. Adjustments or deviations to the steam and oxygen input rates are about: $\pm 2 \%$

3. Deviations or differences in the product gas composition as observed by the on-line gas chromatograph are about: $\pm 2 \%$

4. The variations in reactor bed temperature profiles is on the order of: $\pm 75^{\circ} \mathrm{F}$

Once these criteria are met, the PRU is operated for a predetermined duration. Data are collected during this time period that enable the establishment of material and energy balances. Corrections are made to the raw data to establish $100 \%$ elemental and material balances before any correlation of the data to predict gasifier performance is made.

The following procedure was adopted to adjust the raw data to a $100 \%$ elemental and material balance and used for all of the gasification tests:

1. The product gas flow rate based on the orifice meter measurement has inherent inaccuracies due to the buildup of carryover solids across the orifice plate. Thus, the product gas flow rate was obtained by using the product gas composition from the off-line GC and calculating a $100 \%$ carbon balance. Four equations with four unknowns were solved simultaneously to obtain the product gas flow rate and the quantities of carbon in the entrained solids, in the tars and oils, and in the dry product gas.

2. Next, the hydrogen balance was obtained by adjusting the liquid condensate rate to match the total hydrogen in the input streams.

3. After the product gas flow rate and the condensate collection rate were corrected, the input oxygen rate was adjusted to balance with the total oxygen in the output streams.

4. The input nitrogen flow rate was adjusted to match the nitrogen in the product gases.

5. Because the fluidized-bed gasifier contains very little of the feed material in a residual form, it is assumed that the entire ash in the 
feed material is carried overhead by the product gases. The input feed ash is assigned to the ash in the entrained solids to obtain a $100 \%$ ash balance.

Using this procedure, the measured results from all the tests were adjusted to close the elemental and mass balances, which are summarized in the following tables. The overall energy balances calculated from the adjusted material balances are also presented.

$171 /$ RPP/65058ApD 
Table E-1. MATERIAL AND ENERGY BALANCE SUMMARY FOR RENUGAS PRU TEST GT-1

$$
\begin{aligned}
& \text { Test Date: 3-21-84 } \\
& \text { Study Period: Fron 1645 Hour to } 2045 \text { Hour }
\end{aligned}
$$

\begin{tabular}{|c|c|c|c|c|c|c|c|}
\hline Input & C & H & 0 & $\mathbf{N}$ & Ash & Total & $10^{6} \mathrm{Btu}$ \\
\hline Blomass (Dry) & 364.1 & 45.5 & 325.4 & 0.0 & 10.4 & 745.5 & 6.1 \\
\hline Steam to BIng & & 42.7 & 341.3 & & & 384.0 & 0.5 \\
\hline Steam to Nozzle & & 29.1 & 232.7 & & & 261.8 & 0.3 \\
\hline Oxygen to Nozzle & & & 171.8 & & & 171.8 & \\
\hline N1trogen Purge & & & & 421.9 & & 421.9 & \\
\hline Total Input & 364.1 & 124.9 & 1131.9 & 421.9 & 10.4 & 2052.9 & 6.9 \\
\hline Output & & & & & & & \\
\hline Entrained Solids & 29.1 & 0.0 & & & 10.4 & 39.5 & 0.5 \\
\hline $011 / \mathrm{Tar} 8$ & 13.8 & 2.4 & & & & 16.2 & 0.3 \\
\hline Product Gas Components & & & & & & & \\
\hline $\mathrm{H}_{2}$ & & 18.7 & & & & 18.7 & \\
\hline $\mathrm{CO}$ & 64.5 & & 86.0 & & & 150.5 & \\
\hline $\mathrm{CO}_{2}$ & 165.5 & & 441.4 & & & 606.9 & \\
\hline $\mathrm{CH}_{4}$ & 78.3 & 26.1 & & & & 104.3 & \\
\hline $\mathrm{C}_{2} \mathrm{H}_{4}$ & 2.1 & 0.4 & & & & 2.5 & \\
\hline $\mathrm{C}_{6} \mathrm{H}_{6}$ & 5.1 & 0.4 & & & & 5.5 & \\
\hline $\mathbf{N}_{2}$ & & & & 422.0 & & 422.0 & \\
\hline $\mathrm{H}_{2} \mathrm{O}$ & & 75.5 & 604.1 & & & 679.6 & \\
\hline Total Gas & 321.2 & 122.5 & 1131.4 & 422.0 & & 1997.1 & 6.1 \\
\hline Total Output & 364.1 & 124.9 & 1131.4 & 422.0 & 10.4 & 2052.9 & 6.9 \\
\hline Balance (Output/Input), 7 & 100.0 & 100.0 & 100.0 & 100.0 & 100.0 & 100.0 & 100.0 \\
\hline
\end{tabular}

Bas1s: 1 Hour; All Units in Pounds Unless Otherwise Noted. 
Table E-2 - MATERIAL AND ENERGY BALANCE SUMMARY FOR RENUGAS PRU TEST GT-2

Test Date: 4-11-84

Study Period: From 1325 Hour to 1725 Hour

Bas18: 1 Hour; All Units In Pounds Unless Otherwlse Noted.

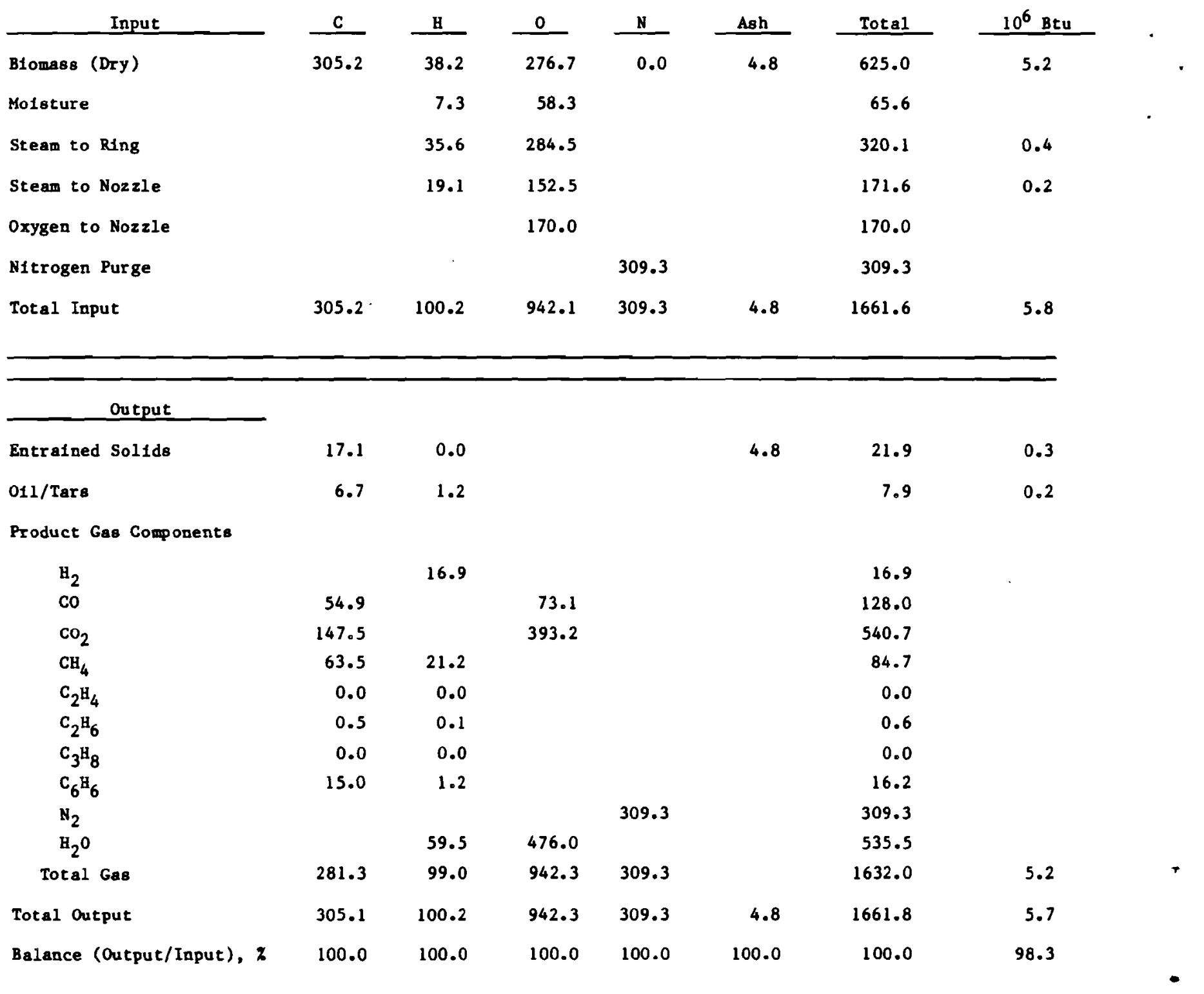

171/RPP/65058ApE 
Table E-3 - MATERIAL AND ENERGY BALANCE SUMMARY FOR RENUGAS PRU TEST GT-4

Test Date: 5-24-84

Study Period: From 1230 Hour to 1630 Hour

Bas18: 1 Hour; All Units in Pounds Unless Otherwise Noted.

\begin{tabular}{|c|c|c|c|c|c|c|c|}
\hline Input & C & H & 0 & $\mathrm{~N}$ & Ash & Total & $10^{6} \mathrm{Btu}$ \\
\hline Biomass (Dry) & 322.1 & 40.7 & 294.3 & 0.7 & 3.1 & 660.9 & 5.5 \\
\hline Moisture & & 7.9 & 63.1 & & & 71.0 & \\
\hline Steam to R1ng & & 29.5 & 235.6 & & & 265.1 & 0.4 \\
\hline Steam to Nozzle & & 19.6 & 157.2 & & & 176.8 & 0.2 \\
\hline Oxygen to Nozzle & & & 249.4 & & & 249.4 & \\
\hline Nitrogen Purge & & & & 373.5 & & 373.5 & \\
\hline Total Input & 322.1 & 97.7 & 999.6 & 374.2 & 3.1 & 1796.7 & 6.1 \\
\hline Output & & & & & & & \\
\hline Entrained Solids & 16.7 & 0.0 & & & 3.1 & 19.7 & 0.2 \\
\hline $011 / \operatorname{Tar} B$ & 1.9 & 0.3 & & & & 2.2 & \\
\hline Product Gas ComponentB & & & & & & & \\
\hline $\mathrm{H}_{2}$ & & 22.4 & & & & 22.4 & \\
\hline Co & 98.1 & & 130.7 & & & 228.8 & \\
\hline $\mathrm{CO}_{2}$ & 153.1 & & 408.3 & & & 561.4 & \\
\hline $\mathrm{CH}_{4}$ & 52.3 & 17.4 & & & & 69.7 & \\
\hline $\mathrm{C}_{2} \mathrm{H}_{4}$ & 0.0 & 0.0 & & & & 0.0 & \\
\hline $\mathrm{C}_{2} \mathrm{H}_{6}$ & 0.0 & 0.0 & & & & 0.0 & \\
\hline $\mathrm{C}_{3} \mathrm{H}_{8}$ & 0.0 & 0.0 & & & & 0.0 & \\
\hline $\mathrm{C}_{6} \mathrm{H}_{6}$ & 0.0 & 0.0 & & & & 0.0 & \\
\hline $\mathrm{N}_{2}$ & & & & 374.3 & & 374.3 & \\
\hline $\mathrm{H}_{2} \mathrm{O}$ & & 57.6 & 460.7 & & & 518.3 & \\
\hline Total Gas & 303.5 & 97.4 & 999.8 & 374.3 & & 1775.0 & 5.4 \\
\hline Total Output & 322.1 & 97.7 & 999.8 & 374.3 & 3.1 & 1797.0 & 5.6 \\
\hline Balance (Output/Input), $\varnothing$ & 100.0 & 100.0 & 100.0 & 100.0 & 100.0 & 100.0 & 91.8 \\
\hline
\end{tabular}


Table E-4. MATERIAL AND ENERGY BALANCE SUMMARY FOR RENUGAS PRU TEST GT-5

Test Date: 6-13-84

Study Period: From 1250 Hour to 1650 Hour

Basis: 1 Hour; All Units In Pounds Unless Otherwise Noted.

\begin{tabular}{|c|c|c|c|c|c|c|c|}
\hline Input & c & $\mathbf{H}$ & 0 & $\mathbf{N}$ & Ash & Total & $10^{6} \mathrm{Btu}$ \\
\hline Blomass (Dry) & 312.9 & 40.2 & 292.5 & 0.3 & 2.6 & 648.5 & 5.3 \\
\hline Molsture & & 8.4 & 67.4 & & & 75.8 & \\
\hline Steam to Rfing & & 38.0 & 304.4 & & & 342.4 & 0.5 \\
\hline Steam to Nozzle & & 24.1 & 193.1 & & & 217.2 & 0.3 \\
\hline Oxygen to Nozzle & & & 123.4 & & & 123.4 & \\
\hline N1trogen Purge & & & & 304.9 & & 304.9 & \\
\hline Total Input & 312.9 & 110.8 & 980.8 & 305.2 & 2.6 & 1712.2 & 6.1 \\
\hline Output & & & & & & & \\
\hline Entralned Solids & 39.9 & 0.7 & & & 2.6 & 43.4 & 0.6 \\
\hline $011 / \operatorname{Tar} 8$ & 15.6 & 2.8 & & & & 18.4 & 0.4 \\
\hline Product Gas Components & & & & & & & \\
\hline $\mathrm{H}_{2}$ & & 14.0 & & & & 14.0 & \\
\hline Co & 35.6 & & 47.5 & & & 83.2 & \\
\hline $\mathrm{CO}_{2}$ & 139.4 & & 371.8 & & & 511.3 & \\
\hline $\mathrm{CH}_{4}$ & 54.3 & 18.1 & & & & 72.4 & \\
\hline $\mathrm{C}_{2} \mathrm{H}_{4}$ & 1.8 & 0.3 & & & & 2.0 & \\
\hline $\mathrm{C}_{2} \mathrm{H}_{6}$ & 14.7 & 3.7 & & & & 18.4 & \\
\hline $\mathrm{C}_{3} \mathrm{H}_{8}$ & 0.5 & 0.1 & & & & 0.6 & \\
\hline $\mathrm{C}_{6} \mathrm{H}_{6}$ & 11.0 & 0.9 & & & & 12.0 & \\
\hline $\mathrm{N}_{2}$ & & & & 305.1 & & 305.1 & \\
\hline $\mathrm{H}_{2} \mathrm{O}$ & & 70.2 & 561.6 & & & 631.8 & \\
\hline Total Gas & 257.4 & 107.4 & 981.0 & 305.1 & & 1650.8 & 4.8 \\
\hline Total Output & 312.9 & 110.8 & 981.0 & 305.1 & 2.6 & 1712.4 & 5.8 \\
\hline Balance (Output/Input), z & 100.0 & 100.0 & 100.0 & 100.0 & 100.0 & 100.0 & 95.1 \\
\hline
\end{tabular}


Table E-5. MATERIAL AND ENERGY BALANCE SUMMARY FOR RENUGAS PRU TEST GT-6

$$
\begin{aligned}
& \text { Test Date: } 6-28-84 \\
& \text { Study Period: From 1130 Hour to } 1530 \text { Hour }
\end{aligned}
$$

\begin{tabular}{|c|c|c|c|c|c|c|c|}
\hline Input & C & $\mathbf{H}$ & 0 & $\mathbf{N}$ & Ash & Total & $10^{6} \mathrm{Btu}$ \\
\hline Blomass (Dry) & 302.6 & 38.3 & 273.9 & 0.2 & 4.1 & 619.2 & 5.1 \\
\hline Molsture & & 8.3 & 66.1 & & & 74.3 & \\
\hline Steam to Rfing & & 40.8 & 326.5 & & & 367.3 & 0.5 \\
\hline Steam to Nozzle & & 25.3 & 202.2 & & & 227.5 & 0.3 \\
\hline Oxygen to Nozzle & & & 167.3 & & & 167.3 & \\
\hline N1trogen Purge & & & & 349.1 & & 349.1 & \\
\hline Total Input & 302.6 & 112.7 & 1036.0 & 349.3 & 4.1 & 1804.7 & 5.9 \\
\hline \multicolumn{8}{|l|}{ Output } \\
\hline Entralned Sollds & 24.2 & 0.0 & & & 4.1 & 28.3 & 0.4 \\
\hline $011 /$ Tars & 11.5 & 2.0 & & & & 13.5 & 0.3 \\
\hline \multicolumn{8}{|l|}{ Product Gas Components } \\
\hline $\mathrm{H}_{2}$ & & 13.3 & & & & 13.3 & \\
\hline $\mathrm{CO}$ & 52.9 & & 70.5 & & & 123.4 & \\
\hline $\mathrm{CO}_{2}$ & 137.9 & & 367.7 & & & 505.7 & \\
\hline $\mathrm{CH}_{4}$ & 58.7 & 19.6 & & & & 78.3 & \\
\hline $\mathrm{C}_{2} \mathrm{H}_{4}$ & 1.6 & 0.3 & & & & 1.8 & \\
\hline $\mathrm{C}_{2} \mathrm{H}_{6}$ & 8.9 & 2.2 & & & & 11.1 & \\
\hline $\mathrm{C}_{3} \mathrm{H}_{8}$ & 0.0 & 0.0 & & & & 0.0 & \\
\hline $\mathrm{C}_{6} \mathrm{H}_{6}$ & 7.1 & 0.6 & & & & 7.7 & \\
\hline $\mathrm{N}_{2}$ & & & & 349.2 & & 349.2 & \\
\hline $\mathrm{B}_{2} \mathrm{O}$ & & 74.7 & 597.7 & & & 672.4 & \\
\hline Total Gas & 267.0 & 110.6 & 1035.9 & 349.2 & & 1762.7 & 5.0 \\
\hline Total Output & 302.8 & 112.6 & 1035.9 & 349.2 & 4.1 & 1804.6 & 5.7 \\
\hline Balance (Output/Input), $z$ & 100.1 & 100.0 & 100.0 & 99.9 & 100.0 & 100.0 & 96.6 \\
\hline
\end{tabular}

Bas1s: 1 Hour; All Untts in Pounds Uniess Otherwise Noted. 
Table E-6 - MATERIAL AND ENERGY BALANCE SUMMARY FOR RENUGAS PRU TEST GT-8

$$
\begin{aligned}
& \text { Test Date: } 8-2-84 \\
& \text { Study Perlod: Fr om } 1130 \text { Hour to } 1400 \text { Hour }
\end{aligned}
$$

\begin{tabular}{|c|c|c|c|c|c|c|c|}
\hline Input & C & H & 0 & N & Ash & Total & $10^{6} \mathrm{Btu}$ \\
\hline B1omsss (Dry) & 326.1 & 41.9 & 295.6 & 0.7 & 2.5 & 666.7 & 5.5 \\
\hline Mo1sture & & 9.3 & 74.4 & & & 83.7 & \\
\hline Steam to R1ng & & 33.1 & 264.4 & & & 297.5 & 0.4 \\
\hline Steam to Nozzle & & 21.2 & 169.9 & & & 191.1 & 0.2 \\
\hline Oxygen to Nozzle & & & 166.3 & & & 166.3 & \\
\hline N1trogen Purge & & & & 390.8 & & 390.8 & \\
\hline Total Input & 326.1 & 105.5 & 970.6 & 391.5 & 2.5 & 1796.1 & 6.1 \\
\hline Output & & & & & & & \\
\hline Entralned Sollds & 23.8 & 0.4 & & & 2.5 & 26.3 & 0.4 \\
\hline $011 /$ Tars & 7.1 & 1.8 & & & & 8.9 & 0.2 \\
\hline Product Gas Components & & & & & & & \\
\hline $\mathrm{H}_{2}$ & & 16.0 & & & & 16.0 & \\
\hline $\mathrm{co}$ & 63.8 & & 85.0 & & & 148.8 & \\
\hline $\mathrm{CO}_{2}$ & 144.6 & & 385.7 & & & 530.3 & \\
\hline $\mathrm{CH}_{4}$ & 65.2 & 21.7 & & & & 86.9 & \\
\hline $\mathrm{C}_{2} \mathrm{H}_{4}$ & 3.7 & 0.6 & & & & 4.3 & \\
\hline $\mathrm{C}_{2} \mathrm{H}_{6}$ & 6.0 & 1.5 & & & & 7.5 & \\
\hline $\mathrm{C}_{3} \mathrm{H}_{8}$ & 0.0 & 0.0 & & & & 0.0 & \\
\hline $\mathrm{C}_{6} \mathrm{H}_{6}$ & 12.1 & 1.0 & & & & 13.1 & \\
\hline $\mathbf{N}_{2}$ & & & & 391.5 & & 391.5 & \\
\hline $\mathrm{H}_{2} \mathrm{O}$ & & 62.5 & 500.0 & & & 562.5 & \\
\hline Total Gas & 295.3 & 103.3 & 970.7 & 391.5 & & 1760.9 & 5.5 \\
\hline Total Output & 326.2 & 105.5 & 970.7 & 391.5 & 2.5 & 1796.5 & 6.1 \\
\hline Balance (Output/Input), $z$ & 100.0 & 100.0 & 100.0 & 100.0 & 100.0 & 100.0 & 100.0 \\
\hline
\end{tabular}

Bas1s: 1 Hour; All Un1ts 1n Pounds Unless Otherwise Noted. 
Table $\overline{\mathrm{i}}-7$. MATERIAL AND ENERGY BALANCE SUMMARY FOR RENUGAS PRU TEST GT-9

Test Date: 10-11-84

Study Period: From 1300 Hour to 1600 Hour

Basis: 1 Hour; All Units in Pounds Unless Otherwise Noted.

\begin{tabular}{|c|c|c|c|c|c|c|c|}
\hline Input & C & H & 0 & $\mathbf{N}$ & Ash & Total & $10^{6} \mathrm{Btu}$ \\
\hline Biomass (Dry) & 331.8 & 41.0 & 294.7 & 0.6 & 2.5 & 670.6 & 5.6 \\
\hline Molsture & & 10.6 & 84.7 & & & 95.3 & \\
\hline Steam to Ring & & 25.7 & 205.6 & & & 231.3 & 0.3 \\
\hline Steam to Nozzle & & 16.9 & 135.0 & & & 151.9 & 0.2 \\
\hline Oxygen to Nozzle & & & 161.4 & & & 161.4 & \\
\hline N1trogen Purge & & & & 159.5 & & 159.5 & \\
\hline Total Input & 331.8 & 94.1 & 881.4 & 160.1 & 2.5 & 1470.0 & 6.1 \\
\hline Output & & & & & & & \\
\hline Entrained Solids & 26.7 & 0.4 & & & 2.5 & 29.7 & 0.4 \\
\hline $011 / \operatorname{Tar} 8$ & 11.5 & 0.8 & & & & 12.3 & 0.3 \\
\hline Product Gas Components & & & & & & & \\
\hline $\mathrm{H}_{2}$ & & 13.0 & & & & 13.0 & \\
\hline $\mathrm{Co}$ & 56.0 & & 74.7 & & & 130.7 & \\
\hline $\mathrm{CO}_{2}$ & 140.2 & & 373.9 & & & 514.1 & \\
\hline $\mathrm{CH}_{4}$ & 63.3 & 21.1 & & & & 84.4 & \\
\hline $\mathrm{C}_{2} \mathrm{H}_{4}$ & 4.3 & 0.7 & & & & 5.0 & \\
\hline $\mathrm{C}_{2} \mathrm{H}_{6}$ & 8.9 & 2.2 & & & & 11.1 & \\
\hline $\mathrm{C}_{3} \mathrm{H}_{8}$ & 0.0 & 0.0 & & & & 0.0 & \\
\hline $\mathrm{C}_{6} \mathrm{H}_{6}$ & 21.0 & 1.7 & & & & 22.7 & \\
\hline $\mathbf{N}_{2}$ & & & & 160.2 & & 160.2 & \\
\hline $\mathrm{H}_{2} \mathrm{O}$ & & 54.1 & 432.8 & & & 486.9 & \\
\hline Total Gas & 293.7 & 92.9 & 881.4 & 160.2 & & 1428.2 & 5.2 \\
\hline Total Output & 331.9 & 94.1 & 881.4 & 160.2 & 2.5 & 1470.2 & 5.9 \\
\hline Balance (Output/Input), $z$ & 100.0 & 99.9 & 100.0 & 100.1 & 100.0 & 100.0 & 96.7 \\
\hline
\end{tabular}


Tále E-8. MATERIAL AND ENERGY BALANCE SUMMARY FOR RENUGAS PRU TEST GT-10

Test Date: 10-25-84

Study Period: From 1415 Hour to 1800 Hour

Bas18: 1 Hour; All Units 1n Pounds Unless Otherwise Noted.

\begin{tabular}{|c|c|c|c|c|c|c|c|}
\hline Input & $\mathrm{c}$ & H & 0 & $\mathbf{N}$ & Ash & Total & $10^{6} \mathrm{Btu}$ \\
\hline Biomass (Dry) & 174.2 & 21.4 & 153.1 & 0.4 & 2.1 & 351.2 & 2.9 \\
\hline Moisture & & 5.4 & 42.9 & & & 48.3 & 0.2 \\
\hline Steam to RAng & & 16.7 & 133.4 & & & 150.1 & 0.1 \\
\hline Steam to Nozzle & & 10.8 & 86.5 & & & 97.3 & \\
\hline Oxygen to Nozzle & & & 91.5 & & & 91.5 & \\
\hline Nitrogen Purge & & & & 302.0 & & 302.0 & \\
\hline Total Input & 174.2 & 54.3 & 507.4 & 302.4 & 2.1 & 1040.4 & 3.2 \\
\hline Output & & & & & & & \\
\hline Entralned Sol1ds & 7.0 & 0.1 & & & 2.1 & 8.4 & 0.1 \\
\hline $011 / \operatorname{Tar} 8$ & 1.1 & 0.1 & & & & 1.2 & - \\
\hline Product Gas Components & & & & & & & \\
\hline $\mathrm{H}_{2}$ & & 7.1 & & & & 7.1 & \\
\hline co & 41.1 & & 54.8 & & & 95.8 & \\
\hline $\mathrm{CO}_{2}$ & 67.5 & & 179.9 & & & 247.3 & \\
\hline $\mathrm{CB}_{4}$ & 27.6 & 9.2 & & & & 36.8 & \\
\hline $\mathrm{C}_{2} \mathrm{H}_{4}$ & 5.1 & 0.9 & & & & 6.0 & \\
\hline $\mathrm{C}_{2} \mathrm{H}_{6}$ & 4.2 & 1.0 & & & & 5.2 & \\
\hline $\mathrm{C}_{3} \mathrm{H}_{8}$ & 0.2 & 0.0 & & & & 0.2 & \\
\hline $\mathrm{C}_{6} \mathrm{H}_{6}$ & 20.4 & 1.7 & & & & 22.1 & \\
\hline $\mathrm{N}_{2}$ & & & & 302.5 & & 302.5 & \\
\hline $\mathrm{b}_{2} \mathrm{O}$ & & 34.1 & 272.8 & & & 306.9 & \\
\hline Total Gas & 166.1 & 54.1 & 507.4 & 302.5 & & 1030.0 & 3.0 \\
\hline Total Output & 174.2 & 54.3 & 507.4 & 302.5 & 2.1 & 1040.5 & 3.1 \\
\hline Balance (Output/Input), $z$ & 100.0 & 100.0 & 100.0 & 100.0 & 100.0 & 100.0 & 96.9 \\
\hline
\end{tabular}


Table E-9. MATERIAL AND ENERGY BALANCE SUMMARY FOR RENUGAS PRU TEST GT-11

Test Date: 11-8-84

Study Perlod: From 1130 Hour to 1600 Hour

Bas18: 1 Hour; All Units in Pounds Unless Otherwlse Noted.

\begin{tabular}{|c|c|c|c|c|c|c|c|}
\hline Input & $\mathrm{c}$ & H & 0 & $\mathbf{N}$ & Ash & Total & $10^{6}$ Btu \\
\hline B1omass (Dry) & 455.0 & 56.7 & 410.6 & 0.0 & 4.2 & 926.5 & 7.7 \\
\hline Molsture & & 11.5 & 91.7 & & & 103.2 & \\
\hline Steam to RIng & & 33.3 & 266.3 & & & 299.6 & 0.4 \\
\hline Steam to Nozzle & & 21.4 & 171.6 & & & 193.0 & 0.2 \\
\hline Oxygen to Nozzle & & & 203.3 & & & 203.3 & \\
\hline N1trogen Purge & & & & 297.7 & & 297.7 & \\
\hline Total Input & 455.0 & 122.9 & 1143.5 & 297.7 & 4.2 & 2023.3 & 8.3 \\
\hline Output & & & & & & & \\
\hline Entrained Solids & 37.3 & 0.6 & & & 4.2 & 41.7 & 0.6 \\
\hline $011 /$ Tars & 20.1 & 1.5 & & & & 21.6 & 0.4 \\
\hline \multicolumn{8}{|l|}{ Product Gas Components } \\
\hline $\mathrm{B}_{2}$ & & 18.8 & & & & 18.8 & \\
\hline co & 102.3 & & 136.4 & & & 238.7 & \\
\hline $\mathrm{CO}_{2}$ & 170.1 & & 453.5 & & & 623.5 & \\
\hline $\mathrm{CH}_{4}$ & 79.5 & 26.5 & & & & 106.0 & \\
\hline $\mathrm{C}_{2} \mathrm{H}_{4}$ & 5.9 & 1.0 & & & & 6.9 & \\
\hline $\mathrm{C}_{2} \mathrm{H}_{6}$ & 11.8 & 2.9 & & & & 14.7 & \\
\hline $\mathrm{C}_{3} \mathrm{H}_{8}$ & 0.0 & 0.0 & & & & 0.0 & \\
\hline $\mathrm{C}_{6} \mathrm{H}_{6}$ & 28.1 & 2.3 & & & & 30.4 & \\
\hline$N_{2}$ & & & & 297.7 & & 297.7 & \\
\hline $\mathrm{H}_{2} \mathrm{O}$ & & 69.2 & 553.6 & & & 622.8 & \\
\hline Total Gas & 397.6 & 120.8 & 1143.4 & 297.7 & & 1959.5 & 7.2 \\
\hline Total Output & 455.1 & 122.8 & 1143.4 & 297.7 & 4.2 & 2023.2 & 8.2 \\
\hline Balance (Ou tput/Input), $z$ & 100.0 & 99.9 & 100.0 & 100.0 & 100.0 & 100.0 & 98.8 \\
\hline
\end{tabular}


Table E-10 - MATERIAL AND ENERGY BALANCE SUMMARY FOR RENUGAS PRU TEST GT-13

$$
\begin{aligned}
& \text { Test Date: 12-13-84 } \\
& \text { Study Period: From } 1300 \text { Hour to } 1645 \text { Hour }
\end{aligned}
$$

\begin{tabular}{|c|c|c|c|c|c|c|c|}
\hline Input & C & $\mathbf{H}$ & 0 & $\mathbf{N}$ & Ash & Total & $10^{6}$ Btu \\
\hline Blomass (Dry) & 322.8 & 41.7 & 298.7 & 0.8 & 7.0 & 671.0 & 5.5 \\
\hline Molsture & & 7.9 & 63.2 & & & 71.1 & \\
\hline Steam to Ring & & 25.9 & 207.0 & & & 232.9 & 0.3 \\
\hline Steam to Nozzle & & 18.0 & 143.9 & & & 161.9 & 0.2 \\
\hline Oxygen to Nozzle & & & 168.1 & & & 168.1 & \\
\hline N1trogen Purge & & & & 263.7 & & 263.7 & \\
\hline Total Input & 322.8 & 93.4 & 880.9 & 264.5 & 7.0 & 1568.7 & 6.0 \\
\hline Output & & & & & & & \\
\hline Entralned Solids & 32.5 & 0.4 & & & 7.0 & 38.2 & 0.5 \\
\hline 011/Tars & 5.4 & 0.4 & & & & 5.8 & 0.1 \\
\hline Product Gas Components & & & & & & & \\
\hline $\mathrm{H}_{2}$ & & 19.9 & & & & 19.9 & \\
\hline $\mathrm{Co}$ & 61.0 & & 81.4 & & & 142.4 & \\
\hline $\mathrm{CO}_{2}$ & 148.9 & & 397.1 & & & 546.1 & \\
\hline $\mathrm{CH}_{4}$ & 58.8 & 19.6 & & & & 78.4 & \\
\hline $\mathrm{C}_{2} \mathrm{H}_{4}$ & 0.2 & 0.0 & & & & 0.2 & \\
\hline $\mathrm{C}_{2} \mathrm{H}_{6}$ & 8.8 & 2.2 & & & & 11.0 & \\
\hline $\mathrm{C}_{3} \mathrm{H}_{8}$ & 0.0 & 0.0 & & & & 0.0 & \\
\hline $\mathrm{C}_{6} \mathrm{H}_{6}$ & 7.2 & 0.6 & & & & 7.8 & \\
\hline $\mathbf{N}_{2}$ & & & & 264.6 & & 264.6 & \\
\hline $\mathrm{H}_{2} \mathrm{O}$ & & 50.3 & 402.4 & & & 452.7 & \\
\hline Total Gas & 284.9 & 92.6 & 880.9 & 264.6 & & 1523.1 & 5.2 \\
\hline Total Output & 322.8 & 93.4 & 880.9 & 264.6 & 7.0 & 1568.8 & 5.8 \\
\hline Balance (Output/Input), 7 & 100.0 & 100.0 & $100 \cdot 0$ & 100.0 & 100.0 & 100.0 & 96.7 \\
\hline
\end{tabular}

Bas1s: 1 Hour; All Unlts in Pounds Unless Otherwlse Noted. 
Table E-11. MATERIAL AND ENERGY BALANCE SUMMARY FOR RENUGAS PRU TEST GT-14

Test Date: 2-14-85

Study Per1od: From 1200 Hour to 1630 Hour

Bas1s: 1 Hour; All Units in Pounds Unless Otherwise Noted.

\begin{tabular}{|c|c|c|c|c|c|c|c|}
\hline Input & c & H & 0 & $\mathbf{N}$ & Ash & Total & $10^{6} \mathrm{Btu}$ \\
\hline Biomass (Dry) & 339.8 & 42.0 & 307.4 & 1.3 & 12.2 & 702.7 & 5.8 \\
\hline Molsture & & 13.8 & 110.4 & & & 124.2 & \\
\hline N1trogen to Ring & & & & 365.9 & & 365.9 & 0.1 \\
\hline Nitrogen to Nozzle & & & & 416.6 & & 416.6 & 0.1 \\
\hline Oxygen to Nozzle & & & 147.9 & & & 147.9 & \\
\hline N1trogen Purge & & & & 167.8 & & 167.8 & \\
\hline Total Input & 339.8 & 55.8 & 565.7 & 951.9 & 12.2 & 1925.1 & 6.0 \\
\hline Output & & & & & & & \\
\hline Entrained Sollds & 26.9 & 0.4 & & & 12.2 & 33.0 & 0.4 \\
\hline $011 / \operatorname{Tar} 8$ & 20.7 & 1.4 & & & & 22.1 & 0.4 \\
\hline Product Gas Components & & & & & & & \\
\hline $\mathrm{H}_{2}$ & & 8.2 & & & & 8.2 & \\
\hline co & 63.3 & & 84.4 & & & 147.7 & \\
\hline $\mathrm{CO}_{2}$ & 116.6 & & 310.9 & & & 427.5 & \\
\hline $\mathrm{CH}_{4}$ & 51.3 & 17.1 & & & . & 68.4 & \\
\hline $\mathrm{C}_{2} \mathrm{H}_{4}$ & 6.3 & 1.1 & & & & 7.4 & \\
\hline $\mathrm{C}_{2} \mathrm{H}_{6}$ & 10.6 & 2.6 & & & & 13.2 & \\
\hline $\mathrm{C}_{3} \mathrm{H}_{8}$ & 0.0 & 0.0 & & & & 0.0 & \\
\hline $\mathrm{C}_{6} \mathrm{~B}_{6}$ & 44.3 & 3.7 & & & & 48.0 & \\
\hline $\mathrm{N}_{2}$ & & & & 951.4 & & 951.4 & \\
\hline $\mathrm{H}_{2} \mathrm{O}$ & & 21.3 & 169.6 & & & 191.7 & \\
\hline Total Gas & 292.4 & 54.0 & 571.7 & 951.4 & & 1863.5 & 5.2 \\
\hline Total Output & 339.9 & 55.7 & 571.7 & 951.4 & 12.2 & 1925.0 & 6.0 \\
\hline Balance (Output/Iaput), $z$ & 100.0 & 99.8 & 100.0 & 100.0 & 100.0 & 100.0 & 100.0 \\
\hline
\end{tabular}


Table E-12. MATERIAL AND ENERGY BALANCE SUMMARY FOR RENUGAS PRU TEST GT-15

$$
\begin{aligned}
& \text { Test Date: 3-1-85 } \\
& \text { Study Period: From 1130 Hour to } 1500 \text { Hour }
\end{aligned}
$$

\begin{tabular}{|c|c|c|c|c|c|c|c|}
\hline Input & $\mathrm{c}$ & H & 0 & $\mathbf{N}$ & Ash & Total & $10^{6} \mathrm{Btu}$ \\
\hline Btomass (Dry) & 282.8 & 34.7 & 251.6 & 0.9 & 5.9 & 576.0 & 4.8 \\
\hline Mo1sture & & 10.8 & 86.6 & & & 97.4 & \\
\hline Steam to $R 1 n g$ & & 18.0 & 144.4 & & & 162.4 & 0.2 \\
\hline Steam to Nozzle & & 12.7 & 101.5 & & & 114.2 & 0.1 \\
\hline Oxygen to Nozzle & & & 165.2 & & & 165.2 & \\
\hline N1trogen Purge & & & & 588.9 & & 588.9 & 0.1 \\
\hline Total Input & 282.8 & 76.3 & 749.3 & 589.8 & 5.9 & 1704.1 & 5.2 \\
\hline Output & & & & & & & \\
\hline Entrained Solids & 15.5 & 0.2 & & & 5.9 & 19.5 & 0.2 \\
\hline $011 / \operatorname{Tar} 8$ & 12.1 & 0.8 & & & & 12.9 & 0.3 \\
\hline Product Gas Components & & & & & & & \\
\hline $\mathrm{H}_{2}$ & & 12.1 & & & & 12.1 & \\
\hline CO & 61.7 & & 82.2 & & & 143.9 & \\
\hline $\mathrm{CO}_{2}$ & 115.7 & & 308.6 & & & 424.4 & \\
\hline $\mathrm{CH}_{4}$ & 42.9 & 14.3 & & & & 57.2 & \\
\hline $\mathrm{C}_{2} \mathrm{H}_{4}$ & 3.6 & 0.6 & & & & 4.2 & \\
\hline $\mathrm{C}_{2} \mathrm{H}_{6}$ & 4.8 & 1.2 & & & & 6.0 & \\
\hline $\mathrm{C}_{3} \mathrm{H}_{8}$ & 0.0 & 0.0 & & & & 0.0 & \\
\hline $\mathrm{C}_{6} \mathrm{H}_{6}$ & 26.3 & 2.2 & & & & 28.5 & \\
\hline $\mathrm{N}_{2}$ & & & & 589.8 & & 589.8 & \\
\hline $\mathrm{H}_{2} \mathrm{O}$ & & 44.8 & 358.4 & & & 403.2 & \\
\hline Total Gas & 255.0 & 75.2 & 749.3 & 589.8 & & 1669.3 & 4.5 \\
\hline Total Output & 282.6 & 76.3 & 749.3 & 589.8 & 5.9 & 1703.9 & 5.0 \\
\hline Balance (Output/Input), $x$ & 99.9 & 100.0 & 100.0 & 100.0 & 100.0 & 100.0 & 96.2 \\
\hline
\end{tabular}

Bas1s: 1 Hour; All Un1ts in Pounds Unless Otherwise Noted. 
Table E-13. MATERIAL AND ENERGY BALANCE SUMMARY FOR RENUGAS PRU TEST GT-16

$$
\begin{aligned}
& \text { Test Date: } 3-15-85 \\
& \text { Study Perlod: Frow 1130 Hour to } 1500 \text { Hour }
\end{aligned}
$$

\begin{tabular}{|c|c|c|c|c|c|c|c|}
\hline Input & $\mathrm{C}$ & $\mathrm{H}$ & 0 & $\mathbf{N}$ & Ash & Total & $10^{6} \mathrm{Btu}$ \\
\hline Biomass (Dry) & 335.0 & 44.4 & 324.3 & 0.5 & 5.1 & 709.3 & 5.6 \\
\hline Moisture & & 6.6 & 52.7 & & & 59.3 & \\
\hline Steam to R1ng & & 45.4 & 363.3 & & & 408.7 & 0.6 \\
\hline Steam to Nozzle & & 17.8 & 142.3 & & & 160.1 & 0.2 \\
\hline Oxygen to Nozzle & & & 172.4 & & & 172.4 & \\
\hline Nitrogen Purge & & & & 340.1 & & 340.1 & \\
\hline Total Input & 335.0 & 114.2 & 1055.0 & 340.6 & 5.1 & 1849.9 & 6.4 \\
\hline Output & & & & & & & \\
\hline Entrained Sollds & 19.1 & 0.3 & & & 5.1 & 22.0 & 0.3 \\
\hline $011 / \operatorname{Tar} \mathrm{s}$ & 13.8 & 1.0 & & & & 14.8 & 0.3 \\
\hline Product Gas Components & & & & & & & \\
\hline $\mathrm{H}_{2}$ & & 16.7 & & & & 16.7 & \\
\hline $\mathrm{co}$ & 58.2 & & 77.6 & & & 135.7 & \\
\hline $\mathrm{CO}_{2}$ & 151.8 & & 404.7 & & & 556.5 & \\
\hline $\mathrm{CH}_{4}$ & 58.9 & 19.6 & & & & 78.6 & \\
\hline $\mathrm{C}_{2} \mathrm{H}_{4}$ & 2.3 & 0.4 & & & & 2.7 & \\
\hline $\mathrm{C}_{2} \mathrm{H}_{6}$ & 11.7 & 2.9 & & & & 14.6 & \\
\hline $\mathrm{C}_{3} \mathrm{H}_{8}$ & 0.0 & 0.0 & & & & 0.0 & \\
\hline $\mathrm{C}_{6} \mathrm{H}_{6}$ & 19.5 & 1.6 & & & & 21.1 & \\
\hline $\mathrm{N}_{2}$ & & & & 340.5 & & 340.5 & \\
\hline $\mathrm{H}_{2} \mathrm{O}$ & & 71.6 & 572.8 & & & 644.4 & \\
\hline Total Gas & 302.3 & 112.9 & 1055.0 & 340.5 & & 1810.7 & 5.6 \\
\hline Total Output & 335.2 & 114.2 & 1055.0 & 340.5 & 5.1 & 1850.1 & 6.2 \\
\hline Balance (Output/Input), $z$ & 100.0 & 100.0 & 100.0 & 100.0 & 100.0 & 100.0 & 96.9 \\
\hline
\end{tabular}

Bas1s: 1 Hour; All Units in Pounds Unless Otherwlse Noted. 
Table E-14 MATERIAL AND ENERGY BALANCE SUMMARY FOR RENUGAS PRU TEST GT-17

Test Date: 3-29-85

Study Period: From 1615 Hour to 1800 Hour

Bas1s: 1 Hour; All Un1ts in Pounds Unless Otherwise Noted.

\begin{tabular}{|c|c|c|c|c|c|c|c|c|}
\hline Input & $\mathrm{C}$ & $\mathbf{H}$ & 0 & $\mathbf{N}$ & As h & Tota 1 & $10^{6}$ Btu & \\
\hline Biomass (Dry) & 244.1 & 30.9 & 220.6 & 0.6 & 5.5 & 501.7 & 4.1 & \\
\hline Molsture & & 20.3 & 162.8 & & & 183.1 & & \\
\hline Steam to Ring & & 20.7 & 165.9 & & & 186.6 & 0.2 & \\
\hline Steam to Nozzle & & 14.4 & 115.5 & & & 129.9 & 0.2 & \\
\hline Oxygen to Nozzle & & & 223.3 & & & 223.3 & & \\
\hline Nitrogen Purge & & & & 914.9 & & 914.9 & 0.1 & \\
\hline Total Input & 244.1 & 86.4 & 888.0 & 915.5 & 5.5 & 2139.5 & 4.6 & \\
\hline Output & & & & & & & & \\
\hline Entrained Sollds & 8.1 & 0.1 & & & 5.5 & 10.1 & 0.1 & \\
\hline $011 /$ Tars & 0.0 & 0.0 & & & & 0.0 & & \\
\hline
\end{tabular}

Product Gas Components

$\mathrm{B}_{2}$

Co

$\mathrm{CO}_{2}$

$\mathrm{CH}_{4}$

$\mathrm{C}_{2} \mathrm{H}_{4}$

$\mathrm{C}_{2} \mathrm{H}_{6}$

$\mathrm{C}_{3} \mathrm{H}_{8}$

$\mathrm{C}_{6} \mathrm{H}_{6}$

$\mathrm{N}_{2}$

$\mathrm{H}_{2} \mathrm{O}$

Total Gas

Total Output

Balance (Output/Input), 7
13.9

41.7

140.3

41.3

0.0

1.9

0.0

10.7

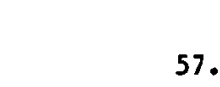

235.8

243.9

99.9

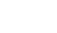

$$
55.6
$$

374.1

13.8

0.0

0.5

0.0

0.9

\section{3}

86.3

86.4

100.0
888.1

881.1

100.
915.4

915.4

915.4

100.0
13.9

97.3

514.4

55.1

0.0

2.4

0.0

11.6

915.4

515.7

2125.7

4.2

5.5

2139.4

4.3

100.0

93.5

171/RPP/65058APE 
Table E-15. MATERIAL AND ENERGY BALANCE SUMMARY FOR RENUGAS PRU TEST T12-1

$$
\begin{aligned}
& \text { Test Date: 6-20-85 } \\
& \text { Study Period: From } 1030 \text { Hour to } 2100 \text { Hour }
\end{aligned}
$$

\begin{tabular}{|c|c|c|c|c|c|c|c|}
\hline Input & C & H & 0 & $\mathbf{N}$ & Ash & Total & $10^{6}$ Btu \\
\hline Blomass (Dry) & 298.4 & 38.3 & 270.7 & 1.2 & 3.5 & 612.1 & 5.1 \\
\hline Molsture & & 3.5 & 28.3 & & & 31.8 & \\
\hline Steam to RIng & & 26.0 & 207.8 & & & 233.8 & 0.3 \\
\hline Stean to Nozzle & & 17.4 & 139.4 & & & 156.8 & 0.2 \\
\hline Oxygen to Nozzle & & & 163.3 & & & 163.3 & \\
\hline N1trogen Purge & & $\cdot$ & & $347 \cdot 6$ & & 347.6 & \\
\hline Total Input & 298.4 & 85.3 & 809.4 & 348.8 & 3.5 & 1545.4 & 5.6 \\
\hline Output & & & & & & & \\
\hline Entralned Solids & 13.0 & 0.2 & & & 3.5 & 15.4 & 0.2 \\
\hline $011 /$ Tar 8 & 16.3 & 1.8 & & & & 18.1 & 0.4 \\
\hline Product Gas Components & & & & & & & \\
\hline $\mathrm{H}_{2}$ & & 15.6 & & & & 15.6 & \\
\hline $\mathrm{CO}$ & 62.3 & & 83.1 & & & 145.4 & \\
\hline $\mathrm{CO}_{2}$ & 132.9 & & 354.4 & & & 487.3 & \\
\hline $\mathrm{CH}_{4}$ & 57.4 & 19.1 & & & & 76.5 & \\
\hline $\mathrm{C}_{2} \mathrm{H}_{4}$ & 0.5 & 0.1 & & & & 0.5 & \\
\hline $\mathrm{C}_{2} \mathrm{H}_{6}$ & 3.4 & 0.9 & & & & 4.3 & \\
\hline $\mathrm{C}_{3} \mathrm{H}_{8}$ & 0.0 & 0.0 & & & & 0.0 & \\
\hline $\mathrm{C}_{6} \mathrm{H}_{6}$ & 12.6 & 1.1 & & & & 13.7 & \\
\hline $\mathbf{N}_{2}$ & & & & $348 \cdot 6$ & & 348.6 & \\
\hline $\mathrm{H}_{2} \mathrm{O}$ & & 46.5 & 372.0 & & & 418.6 & \\
\hline Total Gas & 269.1 & 83.3 & 809.5 & 348.6 & & 1510.6 & 4.8 \\
\hline Total Output & 298.4 & 85.3 & 809.5 & 348.6 & 3.5 & 1545.3 & 5.4 \\
\hline Balance (Output/Input), $z$ & 100.0 & 100.1 & 100.0 & 99.9 & 100.0 & 100.0 & 96.4 \\
\hline
\end{tabular}

Bas1s: 1 Hour; All Units in Pounds Unless Otherwise Noted. 
Table E-16. MATERIAL AND ENERGY BALANCE SUMMARY FOR RENUGAS PRU TEST T12-2

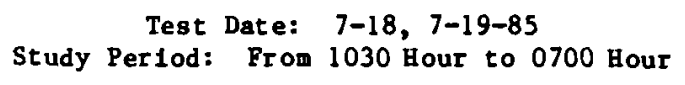

Bas1s: 1 Hour; All Units In Pounds Unless Otherwise Noted.

\begin{tabular}{|c|c|c|c|c|c|c|c|}
\hline Input & c & H & 0 & $\mathbf{N}$ & Ash & Total & $10^{6}$ Btu \\
\hline Blomass (Dry) & 157.6 & 20.5 & 144.1 & 0.7 & 2.7 & 325.7 & 2.7 \\
\hline Mo1sture & & 3.0 & 24.2 & & & 27.2 & \\
\hline Steam to Rfng & & 16.9 & 135.3 & & & 152.2 & 0.2 \\
\hline Steam to Nozzle & & 10.3 & 82.7 & & & 93.0 & 0.1 \\
\hline Oxygen to Nozzle & & & 90.3 & & & 90.3 & \\
\hline N1trogen Purge & & & & 319.8 & & 319.8 & \\
\hline Total Input & 157.6 & 50.8 & 476.6 & 320.5 & 2.7 & 1008.2 & 3.0 \\
\hline Output & & & & & & & \\
\hline Entralned Sollds & 11.5 & 0.2 & & & 2.7 & 14.2 & 0.2 \\
\hline $011 /$ Tars & 8.4 & 0.9 & & & & 9.3 & 0.2 \\
\hline Product Gas Components & & & & & & & \\
\hline $\mathrm{H}_{2}$ & & 4.9 & & & & 4.9 & \\
\hline Co & 38.4 & & 51.1 & & & 89.5 & \\
\hline $\mathrm{CO}_{2}$ & 57.2 & & 152.6 & & & 209.9 & \\
\hline $\mathrm{CH}_{4}$ & 22.8 & 7.6 & & & & 30.3 & \\
\hline $\mathrm{C}_{2} \mathrm{H}_{4}$ & 6.5 & 1.1 & & & & 7.5 & \\
\hline $\mathrm{C}_{2} \mathrm{H}_{6}$ & 5.6 & 1.4 & & & & 7.0 & \\
\hline $\mathrm{C}_{3} \mathrm{H}_{8}$ & 0.1 & 0.0 & & & & 0.2 & \\
\hline $\mathrm{C}_{6} \mathrm{H}_{6}$ & 7.2 & 0.6 & & & & 7.8 & \\
\hline $\mathbf{N}_{2}$ & & & & 320.5 & & 320.5 & \\
\hline $\mathrm{H}_{2} \mathrm{O}$ & & 34.1 & 272.8 & & & 306.9 & \\
\hline Total Gas & 137.7 & 49.7 & 476.6 & 320.5 & & 984.4 & 2.5 \\
\hline Total Output & 157.6 & 50.8 & 476.6 & 320.5 & 2.7 & 1008.2 & 2.9 \\
\hline Balance (Output/Input), 7 & 100.0 & 99.9 & 100.0 & 100.0 & 100.0 & 100.0 & 96.7 \\
\hline
\end{tabular}


Table E-17. MATERIAL AND ENERGY BALANCE SUMMARY FOR RENUGAS PRU TEST T3D-1a

$$
\begin{aligned}
& \text { Test Date: 8-13, 8-15-85 } \\
& \text { Study Per1od: From } 1109 \text { Bour to } 2348 \text { Hour }
\end{aligned}
$$

\begin{tabular}{|c|c|c|c|c|c|c|c|}
\hline Input & $\mathrm{C}$ & 豆 & 0 & $\mathbf{N}$ & Ash & Total & $10^{6} \mathrm{BtI}$ \\
\hline B1omass (Dry) & 185.9 & 23.9 & 168.2 & 0.6 & 2.7 & 381.3 & 3.2 \\
\hline Molsture & & 5.1 & 41.0 & & & 46.2 & \\
\hline Steam to R1ng & & 34.9 & 279.3 & & & 314.2 & 0.4 \\
\hline Steam to Nozzle & & 21.0 & 167.8 & & & 188.8 & 0.2 \\
\hline Oxygen to Nozzle & & & 112.5 & & & 112.5 & \\
\hline N1trogen Purge & & & & 316.0 & & 316.0 & \\
\hline Total Input & 185.9 & 84.9 & 768.9 & 316.6 & 2.7 & 1359.0 & 3.8 \\
\hline \multicolumn{8}{|l|}{ Output } \\
\hline Entrained Sol1ds & 7.4 & 0.1 & & & 2.7 & 9.3 & 0.1 \\
\hline $011 / \operatorname{Tar} 8$ & 5.7 & 0.4 & & & & 6.1 & 0.1 \\
\hline \multicolumn{8}{|l|}{ Product Gas Components } \\
\hline $\mathrm{H}_{2}$ & & 13.2 & & & & 13.2 & \\
\hline co & 26.1 & & 34.9 & & & 61.0 & \\
\hline $\mathrm{CO}_{2}$ & 100.9 & & 269.2 & & & 370.1 & \\
\hline $\mathrm{CH}_{4}$ & 34.9 & 11.6 & & & & 46.5 & \\
\hline $\mathrm{C}_{2} \mathrm{H}_{4}$ & 0.6 & 0.1 & & & & 0.7 & \\
\hline $\mathrm{C}_{2} \mathrm{H}_{6}$ & 2.5 & 0.6 & & & & 3.1 & \\
\hline $\mathrm{C}_{3} \mathrm{H}_{8}$ & 0.0 & 0.0 & & & & 0.0 & \\
\hline $\mathrm{C}_{6} \mathrm{~B}_{6}$ & 7.9 & 0.7 & & & & 8.5 & \\
\hline $\mathrm{N}_{2}$ & & & & 316.6 & & 316.6 & \\
\hline $\mathrm{H}_{2} \mathrm{O}$ & & 58.1 & 464.8 & & & 522.9 & \\
\hline Total Gas & 172.9 & 84.3 & 768.8 & 316.6 & & 1342.6 & 3.5 \\
\hline Total Output & 185.9 & 84.8 & 768.8 & 316.6 & 2.7 & 1358.9 & 3.7 \\
\hline Balance (Output/Input), 7 & 100.0 & 100.0 & 100.0 & 100.0 & 100.0 & 100.0 & 97.4 \\
\hline
\end{tabular}

Bas1s: 1 Hour; All Units 1n Pounds Unless Otherwise Noted. 
Table E-18. MATERIAL AND ENERGY BALANCE SUMMARY FOR RENUGAS PRU TEST T3D-1b

Test Date: 8-16-85

Study Period: From 0228 Hour to 0528 Hour

Bas1s: 1 Hour; All Units in Pounds Unless Otherwise Noted.

\begin{tabular}{|c|c|c|c|c|c|c|c|}
\hline Input & C & H & 0 & $\mathbf{N}$ & $\mathbf{A s h}$ & Total & $10^{6} \mathrm{Btu}$ \\
\hline Blomass (Dry) & 325.3 & 41.8 & 294.3 & 1.1 & 4.8 & 667.2 & 5.5 \\
\hline Moisture & & 9.0 & 71.8 & & & 80.8 & \\
\hline Steam to Ring & & 31.6 & 252.5 & & & 284.1 & 0.4 \\
\hline Steam to Nozzle & & 21.1 & 169.0 & & & 190.1 & 0.2 \\
\hline Oxygen to Nozzle & & & 168.9 & & & 168.9 & \\
\hline Nitrogen Purge & & & & 317.9 & & 317.9 & \\
\hline Total Input & 325.3 & 103.4 & 956.5 & 319.0 & 4.8 & 1709.0 & 6.1 \\
\hline output & & & & & & & \\
\hline Entralned Solids & 10.5 & 0.2 & & & 4.8 & 13.1 & 0.2 \\
\hline $011 /$ Tars & 9.7 & 0.7 & & & & 10.4 & 0.2 \\
\hline Product Gas Components & & & & & & & \\
\hline $\mathrm{H}_{2}$ & & 18.0 & & & & 18.0 & \\
\hline co & 48.9 & & 65.2 & & & 114.2 & \\
\hline $\mathrm{CO}_{2}$ & 151.9 & & 405.0 & & & 556.9 & \\
\hline $\mathrm{CH}_{4}$ & 57.5 & 19.2 & & & & 76.7 & \\
\hline $\mathrm{C}_{2} \mathrm{H}_{4}$ & 0.7 & 0.1 & & & & 0.8 & \\
\hline $\mathrm{C}_{2} \mathrm{H}_{6}$ & 3.5 & 0.9 & & & & 4.4 & \\
\hline $\mathrm{C}_{3} \mathrm{H}_{8}$ & 0.0 & 0.0 & & & & 0.0 & \\
\hline $\mathrm{C}_{6} \mathrm{H}_{6}$ & 42.6 & 3.6 & & & & 46.2 & \\
\hline $\mathbf{N}_{2}$ & & & & 319.0 & & 319.0 & \\
\hline $\mathrm{H}_{2} \mathrm{O}$ & & 60.8 & 486.4 & & & 547.2 & \\
\hline Total Gas & 305.2 & 102.5 & 956.6 & 319.0 & & 1683.3 & 5.6 \\
\hline Total output & 325.4 & 103.4 & 956.6 & 319.0 & 4.8 & 1709.2 & 6.0 \\
\hline Balance (Output/Input), $\bar{x}$ & 100.0 & 100.0 & 100.0 & 100.0 & 100.0 & 100.0 & 98.4 \\
\hline
\end{tabular}


Table E-19. MATERIAL AND ENERGY BALANCE SUMMARY FOR RENUGAS PRU TEST T12-3a

Test Date: 9-19-85

Study Per1od: From 1100 Hour to 1430 Hour

Bas1s: 1 Hour; All Units 1n Pounds Unless Otherwise Noted.

\begin{tabular}{|c|c|c|c|c|c|c|c|}
\hline Input & C & H & 0 & $\mathbf{N}$ & Ash & Total & $10^{6} \mathrm{Btu}$ \\
\hline Blomass (Dry) & 314.1 & 40.0 & 282.6 & 1.2 & 5.5 & 643.4 & 5.3 \\
\hline Molsture & & 7.2 & 57.5 & & & 64.7 & \\
\hline Steam to Ring & & 32.7 & 261.2 & & & 293.9 & 0.4 \\
\hline Steam to Nozzle & & 21.4 & 170.9 & & & 192.3 & 0.3 \\
\hline Oxygen to Nozzle & & & 182.9 & & & 182.9 & \\
\hline N1trogen Purge & & & & 289.8 & & 289.8 & \\
\hline Total Input & 314.1 & 101.2 & 955.2 & 291.0 & 5.5 & 1667.0 & 6.0 \\
\hline \multicolumn{8}{|l|}{ Output } \\
\hline Entralned Solids & 5.4 & 0.1 & & & 5.5 & 6.6 & 0.1 \\
\hline $011 /$ Tars & 6.8 & 0.5 & & & & 7.2 & 0.1 \\
\hline \multicolumn{8}{|l|}{ Product Gas Components } \\
\hline $\mathrm{H}_{2}$ & & 18.4 & & & & 18.4 & \\
\hline $\mathrm{CO}$ & 62.8 & & 83.7 & & & 146.5 & \\
\hline $\mathrm{CO}_{2}$ & 151.5 & & 404.1 & & & 555.6 & \\
\hline $\mathrm{CH}_{4}$ & 66.1 & 22.0 & & & & 88.1 & \\
\hline $\mathrm{c}_{2} \mathrm{H}_{4}$ & 0.0 & 0.0 & & & & 0.0 & \\
\hline $\mathrm{C}_{2} \mathrm{H}_{6}$ & 0.3 & 0.1 & & & & 0.4 & \\
\hline $\mathrm{C}_{3} \mathrm{H}_{8}$ & 0.0 & 0.0 & & & & 0.0 & \\
\hline $\mathrm{C}_{6} \mathrm{H}_{6}$ & 21.4 & 1.8 & & & & 23.2 & \\
\hline $\mathrm{N}_{2}$ & & & & 291.0 & & 291.0 & \\
\hline $\mathrm{H}_{2} \mathrm{O}$ & & 58.4 & 467.4 & & & 525.8 & \\
\hline Total Gas & 302.2 & 100.7 & 955.2 & 291.0 & & 1649.1 & 5.6 \\
\hline Total Output & 314.3 & 101.3 & 955.2 & 291.0 & 5.5 & 1667.3 & 5.8 \\
\hline Balance (Output/Input), $\chi$ & 100.1 & 100.0 & 100.0 & 100.0 & 100.0 & 100.0 & 96.7 \\
\hline
\end{tabular}


Table E-20. MATERIAL AND ENERGY BALANCE SUMMARY FOR RENUGAS PRU TEST T12-3b

Test Date: 9-19-85

Study Perlod: From 1600 Hour to 2000 Hour

Basis: 1 Hour; All Units In Pounds Unless Otherwise Noted.

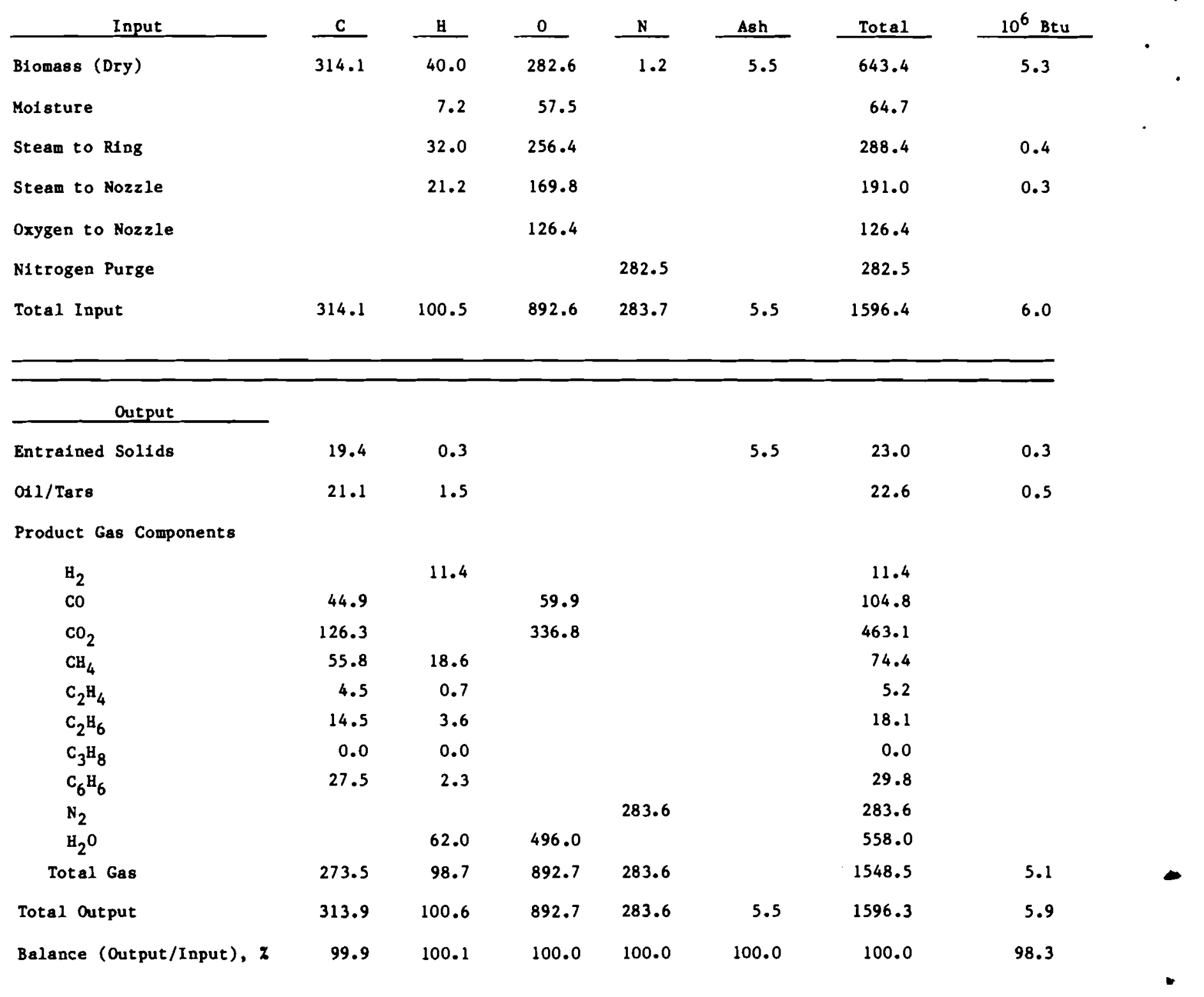


Table E-21. MATERIAL AND ENERGY BALANCE SUMMARY FOR RENUGAS PRU TEST T12-4a Test Date: 10-10-85

Study Perlod: From 1230 Hour to 1600 Hour

Bas1s: 1 Hour; All Units in Pounds Unless Otherwise Noted.

\begin{tabular}{|c|c|c|c|c|c|c|c|}
\hline Input & c & $\mathrm{H}$ & 0 & $\mathbf{N}$ & ABh & Tota1 & $10^{6} \mathrm{Btu}$ \\
\hline Blomass (Dry) & 167.9 & 21.1 & 147.3 & 0.9 & 4.4 & 341.7 & 2.8 \\
\hline Molsture & & 3.7 & 30.0 & & & 33.7 & \\
\hline Steam to Ring & & 18.1 & 144.7 & & & 162.8 & 0.2 \\
\hline Steam to Nozzle & & 12.0 & 95.6 & & & 107.6 & 0.2 \\
\hline Oxygen to Nozzle & & & 99.6 & & & 99.6 & \\
\hline N1trogen Purge & & & & 319.7 & & 319.7 & \\
\hline Total Input & 167.9 & 54.9 & 517.3 & 320.6 & 4.4 & 1065.1 & 3.2 \\
\hline Output & & & & & & & \\
\hline Entrained Solids & 5.2 & 0.1 & & & 4.4 & 6.6 & 0.1 \\
\hline $011 / \operatorname{TarB}$ & 8.6 & 0.6 & & & & 9.2 & 0.2 \\
\hline Product Gas Components & & & & & & & \\
\hline $\mathrm{H}_{\mathbf{2}}$ & & 6.6 & & & & 6.6 & \\
\hline co & 41.5 & & 55.3 & & & 96.8 & \\
\hline $\mathrm{CO}_{2}$ & 63.8 & & 170.1 & & & 233.8 & \\
\hline $\mathrm{CH}_{4}$ & 23.0 & 7.7 & & & & 30.7 & \\
\hline $\mathrm{C}_{2} \mathrm{H}_{4}$ & 6.9 & 1.2 & & & & 8.1 & \\
\hline $\mathrm{C}_{2} \mathrm{H}_{6}$ & 3.7 & 0.9 & & & & 4.7 & \\
\hline $\mathrm{C}_{3} \mathrm{H}_{8}$ & 0.2 & 0.0 & & & & 0.2 & \\
\hline $\mathrm{C}_{6} \mathrm{H}_{6}$ & 15.0 & 1.3 & & & & 16.3 & \\
\hline $\mathrm{N}_{2}$ & & & & 320.5 & & 320.5 & \\
\hline $\mathrm{H}_{2} \mathrm{O}$ & & 36.5 & 292.0 & & & 328.5 & \\
\hline Total Gas & 154.1 & 54.2 & 517.4 & 320.5 & & 1046.1 & 2.9 \\
\hline Total Output & 167.9 & 54.8 & 517.4 & 320.5 & 4.4 & 1065.1 & 3.2 \\
\hline Balance (Output/Input), 7 & 100.0 & 99.9 & 100.0 & 100.0 & 100.0 & 100.0 & 100.0 \\
\hline
\end{tabular}


Table E-22. MATERIAL AND ENERGY BALANCE SUMMARY FOR RENUGAS PRU TEST T12-4b

$$
\begin{aligned}
& \text { Test Date: } 10-10-85 \\
& \text { Study Period: From } 1700 \text { Hour to } 1830 \text { Hour }
\end{aligned}
$$

\begin{tabular}{|c|c|c|c|c|c|c|c|}
\hline Input & $\mathrm{c}$ & $\mathrm{H}$ & 0 & $\mathbf{N}$ & Ash & Total & $10^{6}$ Btu \\
\hline B1omass (Dry) & 166.7 & 21.1 & 146.7 & 0.7 & 4.2 & 339.4 & 2.8 \\
\hline Molsture & & 4.0 & 32.0 & & & 36.0 & \\
\hline Steam to RAng & & 18.3 & 146.1 & & & 164.4 & 0.2 \\
\hline Steam to Nozzle & & 12.1 & 96.5 & & & 108.6 & 0.1 \\
\hline Oxygen to Nozzle & & & 104.6 & & & 104.6 & \\
\hline Nitrogen Purge & & & & 350.9 & & 350.9 & \\
\hline Total Input & 166.7 & 55.5 & 525.9 & 351.6 & 4.2 & 1103.9 & 3.1 \\
\hline \multicolumn{8}{|l|}{ Output } \\
\hline Entralned Solids & 3.4 & 0.1 & & & 4.2 & 4.5 & \\
\hline 011/Tars & 7.9 & 0.5 & & & & 8.4 & 0.2 \\
\hline \multicolumn{8}{|l|}{ Product Gas Components } \\
\hline $\mathrm{H}_{2}$ & & 6.8 & & & & 6.8 & \\
\hline $\mathrm{co}$ & 41.9 & & 55.9 & & & 97.8 & \\
\hline $\mathrm{CO}_{2}$ & 65.9 & & 175.7 & & & 241.5 & \\
\hline $\mathrm{CH}_{4}$ & 25.5 & 8.5 & & & & 33.9 & \\
\hline $\mathrm{C}_{2} \mathrm{H}_{4}$ & 5.5 & 0.9 & & & & 6.4 & \\
\hline $\mathrm{C}_{2} \mathrm{H}_{6}$ & 3.3 & 0.8 & & & & 4.1 & \\
\hline $\mathrm{C}_{3} \mathrm{H}_{8}$ & 0.2 & 0.0 & & & & 0.2 & \\
\hline $\mathrm{C}_{6} \mathrm{H}_{6}$ & 13.3 & 1.1 & & & & 14.4 & \\
\hline $\mathrm{N}_{2}$ & & & & 351.6 & & 351.6 & \\
\hline $\mathrm{H}_{2} \mathrm{O}$ & & 36.8 & 294.4 & & & 331.2 & \\
\hline Total Gas & 155.5 & 55.0 & 526.0 & 351.6 & & 1088.0 & 2.9 \\
\hline Total Output & 166.7 & 55.6 & 526.0 & 351.6 & 4.2 & 1104.0 & 3.1 \\
\hline Balance (Output/Input), $z$ & 100.0 & 100.2 & 100.0 & 100.0 & 100.0 & 100.0 & 100.0 \\
\hline
\end{tabular}

Bas1s: 1 Hour; All Units in Pounds Unless Otherwise Noted. 
APPENDIX F .

Properties of Entrained Solids

F-1 
Properties of Entrained Solids

For tests GT-1, GT-2, and GT-4, the entrained solids were collected from the solids reciever vessel at the end of each test. Starting with test GT-5 and onward, all entrained solids have been collected during the tests by the isokinetic sampling system that has been described in Appendix D.

The complete analyses (including size distribution, proximate and ultimate analyses, heating value, and bulk density) of these solids are presented in this Appendix. The anaylses show that no inert bed material was carried overhead along with the entrained solids and that approximately $80 \%$ by weight of the material is sized 200 mesh or smaller. The high heating value of $\sim 12,000 \mathrm{Btu} / \mathrm{dry} 1 \mathrm{~b}$ makes this material attractive as boiler feed or can be reinjected into the gasifier bed to achieve greater carbon conversion. The subsieve particle analysis of the material collected in the pan was conducted using a coulter-counter. 
Table F-1, Part 1. PROPERTIES OF ENTKAINED SOLIDS

Test No.

IGT Sample No.

Screen Analysis

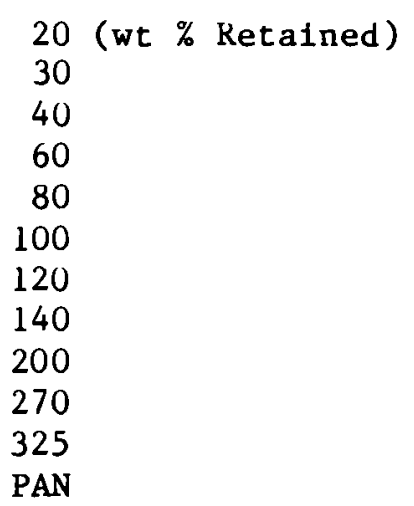

Proximate Analysis, wt \%

Moisture

Volatile Matter

Ash

Fixed Carbon

Total

Ultimate Analysis, dry wt \%

$\begin{array}{llllll}\mathrm{GT}-1 & \mathrm{GT}-2 & \mathrm{GT}-4 & \mathrm{GT}-5 & \mathrm{GT}-0 \\ & & & & & \\ 49281 & 49405 & 49729 & 49835 & 49871 \\ 49282 & 49406 & 49730 & 49836 & \end{array}$

\begin{tabular}{|c|c|c|c|c|}
\hline 0.3 & $\mathrm{~N} / \mathrm{A}$ & 0 & 0.7 & 0.3 \\
\hline 0 & & 0 & 0 & 0 \\
\hline 0.1 & & 0 & 0 & 0.3 \\
\hline 0.5 & & 1.5 & 0.7 & 0.9 \\
\hline 2.5 & & 2.9 & 3.3 & 2.4 \\
\hline 3.0 & & 2.9 & 4.6 & 3.3 \\
\hline 4.0 & & 4.4 & $3 . y$ & 3.3 \\
\hline 5.0 & & 10.1 & 6.5 & 5.1 \\
\hline 6.0 & & 19.6 & 17.6 & 14.4 \\
\hline 21.0 & & 13.5 & 22.9 & 19.5 \\
\hline 9.6 & & 4.4 & 12.4 & 9.6 \\
\hline 38.0 & & 40.7 & 27.4 & 40.9 \\
\hline
\end{tabular}

\begin{tabular}{rrrrr}
5.24 & 3.21 & 4.13 & 5.11 & 2.04 \\
5.19 & N/A & 7.47 & N/A & N/A \\
9.68 & 13.45 & 14.02 & 4.89 & 8.33 \\
79.89 & N/A & $\frac{74.38}{100.00}$ & N/A & N/A \\
\hline 100.00 & -- & --
\end{tabular}

\begin{tabular}{rrrrr}
10.21 & 13.91 & 14.63 & 5.14 & 8.50 \\
85.40 & 81.86 & 80.41 & 89.51 & 85.65 \\
1.23 & 1.22 & 1.05 & 1.62 & 1.47 \\
N/A & N/A & N/A & N/A & N/A \\
N/A & N/A & N/A & N/A & N/A \\
N/A & N/A & N/A & N/A & N/A \\
\hline-- & -- & - & -- & --
\end{tabular}

$12,832 \quad 11,394 \quad 11,788 \quad 13,550 \quad 13,008$

$\begin{array}{lllll}25.1 & 18.2 & 13.4 & 21.4 & 19.2\end{array}$

Bulk Density, $1 \mathrm{~b} / \mathrm{ft}^{3}$

N/A = Not Analyzed.

$171 / \mathrm{RPP} / 65058 \mathrm{ApE}$ 
Table F-1, Part 2. PROPERTIES OF ENTRAINED SOLIDS

Test No.

IGT Sample No.

Screen Analysis

20 (wt \% Retained)
30
40
60
80
100
120
140
200
270
325
PAN

Proximate Analysis, wt \%

Moisture
Volatile Matter
Ash
Fixed Carbon
$\quad$ Total

U1timate Analysis, dry wt \%

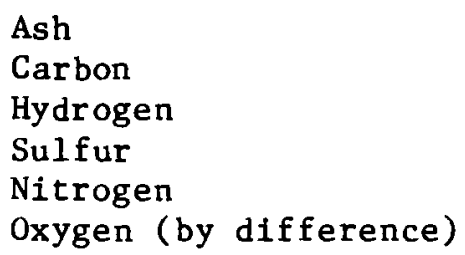
Total

Gross Heating Value, Btu/dry lb

Bulk Density, $1 \mathrm{~b} / \mathrm{ft}^{3}$

N/A $=$ Not Analyzed.

$171 / \mathrm{RPP} / 65058 \mathrm{ApE}$

$$
\begin{array}{lllll}
\mathrm{GT}-8 & \mathrm{GT}-9 & \mathrm{GT}-10 & \mathrm{GT}-11 & \frac{G T-13}{50053} \\
50544 & 50590 & 50656 & 50929
\end{array}
$$

$\begin{array}{rrrrr}0 & 0 & 0 & 0 & 0 \\ 0 & 0 & 0.4 & 0 & 0 \\ 0 & 0.5 & 0.4 & 0.2 & 0 \\ 0.6 & 0.5 & 2.3 & 0.5 & 0.6 \\ 2.6 & 2.2 & 3.0 & 2.2 & 3.8 \\ 3.5 & 2.7 & 2.7 & 2.5 & 4.4 \\ 2.9 & 3.8 & \text { N/A } & \text { N/A } & 4.7 \\ 5.5 & \text { N/A } & 5.7 & 7.5 & 5.3 \\ 13.2 & 15.8 & 10.2 & 13.7 & 11.7 \\ 21.0 & 17.5 & 17.0 & 20.6 & 15.5 \\ 18.4 & 9.3 & 10.6 & 10.0 & 6.7 \\ 32.3 & 47.5 & 47.7 & 43.0 & 47.3\end{array}$

$\begin{array}{rrrrr}3.08 & 7.87 & 4.10 & 18.47 & 4.12 \\ 6.97 & 6.08 & \text { N/A } & 4.16 & 8.84 \\ 7.59 & 5.82 & 11.15 & 3.55 & 12.15 \\ 82.36 & \frac{80.23}{100.00} & \text { N/A } & \frac{73.82}{100.00} & \frac{74.89}{100.00}\end{array}$

$\begin{array}{rrrrr}7.83 & 6.32 & 11.62 & 4.36 & 12.67 \\ 86.90 & 89.80 & 83.40 & 89.54 & 82.18 \\ 1.44 & 1.34 & 1.42 & 1.32 & 1.03 \\ 0.04 & 0.03 & \text { N/A } & 0.03 & 0.03 \\ 0.16 & 0.13 & \text { N/A } & 0.15 & 0.07 \\ 3.63 & 2.38 & \text { N/A } & \frac{4.60}{100.00} & \frac{4.02}{100.00}\end{array}$

$13,204 \quad 13,505 \quad 12,617 \quad 13,692 \quad 12,196$

$\begin{array}{lllll}19.2 & 18.6 & 20.9 & 18.2 & 20.5\end{array}$ 
Table F-1, Part 3. PROPERTIES OF ENTRAINED SOLIDS

Test No.

IGT Sample No.

Screen Analysis

20 (wt \% Retained)
30
40
60
80
100
120
140
200
270
325
PAN

Proximate Analysis, wt \%

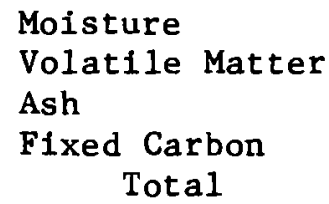

U1timate Analysis, dry wt \%

Ash
Carbon
Hydrogen
Sulfur
Nitrogen
Oxygen (by difference)
$\quad$ Total

Gross Heating Value, Btu/dry $1 b$

Bulk Density, $1 \mathrm{~b} / \mathrm{ft}^{3}$

N/A = Not Analyzed.

$\begin{array}{lllll}\mathrm{GT}-14 & \mathrm{GT}-15 & \mathrm{GT}-16 & \mathrm{GT}-17 & \frac{\mathrm{T} 12-1}{51127} \\ 51255 & 51373 & 51548 & 850604101\end{array}$

$\begin{array}{rrrrr}\text { N/A } & \text { N/A } & \text { N/A } & \text { N/A } & \text { N/A } \\ \text { N/A } & \text { N/A } & \text { N/A } & \text { N/A } & \text { N/A } \\ 0.5 & 0 & 0.5 & 0 & 0 \\ \text { N/A } & \text { N/A } & \text { N/A } & \text { N/A } & \text { N/A } \\ \text { N/A } & \text { N/A } & \text { N/A } & \text { N/A } & \text { N/A } \\ \text { N/A } & \text { N/A } & \text { N/A } & \text { N/A } & \text { N/A } \\ \text { N/A } & \text { N/A } & \text { N/A } & \text { N/A } & \text { N/A } \\ 16.4 & 18.2 & 17.4 & 11.9 & 9.9 \\ 16.9 & 13.1 & 11.4 & 11.0 & 16.9 \\ \text { N/A } & \text { N/A } & \text { N/A } & \text { N/A } & \text { N/A } \\ \text { N/A } & \text { N/A } & \text { N/A } & \text { N/A } & \text { N/A } \\ \text { 45.0 } & 57.0 & 61.1 & 67.9 & 55.0\end{array}$

$\begin{array}{rrrrr}0.70 & 1.68 & 1.50 & 2.06 & 1.74 \\ 8.73 & 10.04 & 6.61 & 11.97 & 7.90 \\ 12.39 & 14.03 & 7.78 & 24.45 & 8.47 \\ \frac{78.18}{100.00} & \frac{74.25}{100.00} & \frac{84.11}{100.00} & \frac{61.52}{100.00} & \frac{81.89}{100.00}\end{array}$

\begin{tabular}{rrrrr}
12.48 & 14.27 & 7.90 & 24.96 & 8.62 \\
81.47 & 79.72 & 87.02 & 68.33 & 84.17 \\
1.08 & 1.04 & 1.49 & 1.21 & 1.41 \\
0.04 & 0.06 & 0.41 & 0.07 & 0.05 \\
0.17 & 0.10 & 0.06 & 0.04 & 0.19 \\
4.76 & $\frac{4.81}{100.00}$ & $\frac{3.12}{100.00}$ & $\frac{5.39}{100.00}$ & $\frac{5.56}{100.00}$ \\
\hline 100.00 & & & & \\
12,168 & 11,724 & 13,237 & 10,064 & 12,732 \\
17.4 & 17.3 & 18.6 & 20.1 & 13.7
\end{tabular}

$171 / 65058 \mathrm{ApE} / \mathrm{RPP}$ 
Table F-1, Part 4. PROPERTIES OF ENTRAINED SOLIDS

Test No.

IGT Sample No.

Screen Analysis

20 (wt \% Retained)
30
40
60
80
100
120
140
200
270
325
PAN

Proximate Analysis, wt \%

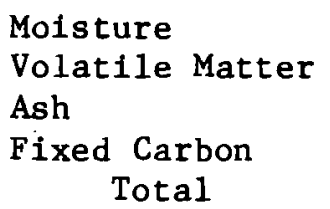

U1timate Analysis, dry wt \%

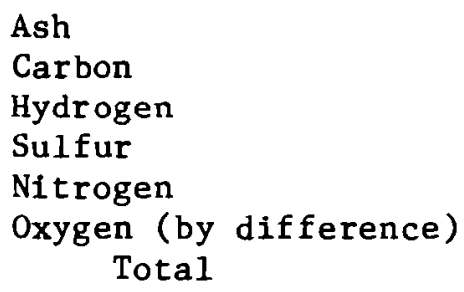

Gross Heating Value, Btu/dry $1 b$

Bulk Density, $1 \mathrm{~b} / \mathrm{ft}^{3}$

N/A $=$ Not Analyzed.

\begin{tabular}{|c|c|c|c|}
\hline T12-2 & T3 $\mathrm{v}-1 \mathrm{a}$ & T3D-1b & $\mathrm{T} 1<-3 \mathrm{a}$ \\
\hline $\begin{array}{l}850702703 \\
850702704\end{array}$ & $\begin{array}{l}850802205 \\
850802206\end{array}$ & 850802208 & 85 \\
\hline & 850802207 & & \\
\hline
\end{tabular}

$$
\text { N/A }
$$

N/A

4.8

$\mathrm{N} / \mathrm{A}$

N/A

N/A

N/A

26.2

$21 \cdot 1$

N/A

N/A

32.3

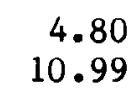

4.80
10.99

11.18

73.03

100.00

5.24
9.37
13.52

71.87

$\frac{71.87}{100.00}$

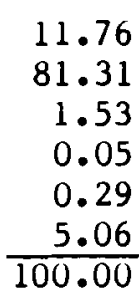

$$
\begin{array}{r}
14.20 \\
79.07 \\
1.38 \\
0.03 \\
0.14 \\
5.18 \\
\hline 100.00
\end{array}
$$

$$
\begin{array}{r}
13.24 \\
80.45 \\
1.37 \\
0.07 \\
0.15 \\
4.72 \\
\hline 100.00
\end{array}
$$

12.42

81.25

1.47

0.04

0.09

12,364

11,934

12,140

$\frac{4.73}{100.00}$

17.2

15.4

14.7

12,244

14.8 
Table F-1, Part 5. PROPERTIES OF ENTKALNED SOLIDS

Test No.

IGT Sample No.

Screen Analysis

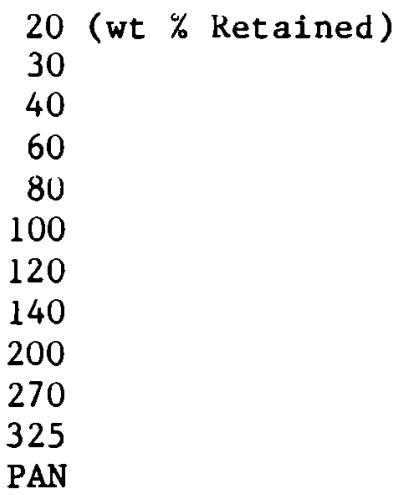

Proximate Analysis, wt \%

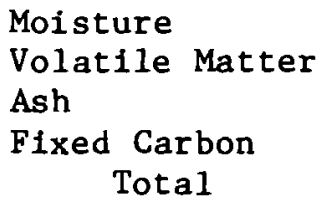

Ultimate Analysis, dry wt \%

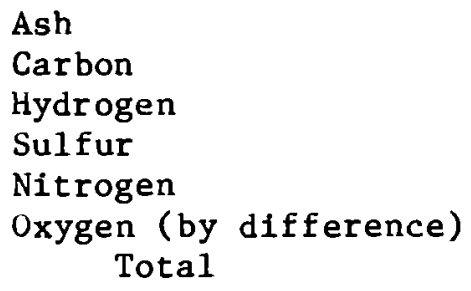

Gross Heating Value, Btu/dry lb

Bulk Density, $1 \mathrm{~b} / \mathrm{ft}^{3}$

$\mathrm{N} / \mathrm{A}=$ Not Analyzed.

$171 / \mathrm{RPP} / 65058 \mathrm{ApE}$

$\frac{T 12-3 b}{850902902} \quad \frac{T 12-4 a}{851001803} \quad \frac{T 12-4 b}{851001804}$.

$\begin{array}{rrr}0 & 0 & 0 \\ 0 & 0 & 0 \\ 0 & 0.3 & 0 \\ 0.3 & 1.1 & 0.7 \\ 3.4 & 2.2 & 0.7 \\ 3.1 & 1.3 & 0.7 \\ 2.8 & 1.6 & 0.7 \\ 7.9 & 3.2 & 2.0 \\ 9.7 & 8.9 & 6.1 \\ 29.4 & 11.3 & 14.9 \\ 9.3 & 33.4 & 28.4 \\ 4.1 & 36.7 & 45.8\end{array}$

\begin{tabular}{rrr}
1.37 & 2.04 & 1.33 \\
8.55 & 9.11 & 10.54 \\
9.55 & 13.37 & 15.90 \\
80.53 & 75.48 & 72.23 \\
\hline 100.00 & $\frac{700.00}{100.00}$
\end{tabular}

\begin{tabular}{rrr}
9.68 & 13.64 & 16.12 \\
84.16 & 79.49 & 75.52 \\
1.49 & 1.27 & 1.31 \\
0.04 & 0.06 & 0.06 \\
0.20 & 0.21 & 0.25 \\
4.43 & 5.33 & $\frac{6.74}{100.00}$ \\
\hline 100.00 & 100.00 & \\
12,825 & 11,946 & 11,412 \\
15.0 & & \\
& 23.2 & 20.1
\end{tabular}


Table F-2. SUBSIEVE PARTICLE ANALYSES OF ENTRAINED SOLIDS

Test No.

Subsieve Particle Analysis
$\underline{G T-1} \quad \underline{G T-2} \quad \underline{G T-4} \quad \underline{G T-5} \quad \underline{G T-6} \quad \underline{\text { GT-8 }}$

N/A

N/A

0.0
0.3
3.2
8.8
17.2
24.4
29.6
33.6
36.9
39.5
40.6
40.7

N/A

0.3
0.3
1.7
6.2
12.3
18.2
23.0
26.6
29.4
31.2
31.9
32.3

GT-9 GT-10

$\underline{\mathrm{GT}-11} \quad \mathrm{GT}-13$

$\underline{G T-14}$

容
N/A

.2

8.8

4.4

29.6

33.6

9.5

40.7
$0.0 \quad 0.0$

0.2

6.8

15.8

25.4

33.2

38.9

42.7

45.3

46.9

47.4

47.5
$0.0 \quad 0.0$

0.5

12.0

20.1

27.7

34.1

39.5

43.4

46.2

47.3

47.7

0.0
0.5
4.4

4.4

11.8

20.9

28.0

33.1

37.0

39.8

41.8

42.6

43.0

$\begin{array}{rr}0.0 & 0.0 \\ 0.4 & 2.6 \\ 4.9 & 9.4 \\ 12.8 & 16.9 \\ 21.2 & 25.4 \\ 28.4 & 31.7 \\ 33.7 & 36.2 \\ 38.4 & 39.5 \\ 42.2 & 41.9 \\ 45.2 & 43.8 \\ 46.5 & 44.5 \\ 47.3 & 45.0\end{array}$

$\underline{\mathrm{GT}-15}$ GT-16 GT-17 $\underline{\mathrm{T} 12-1}$ T12-2 T3D-1a T3D-1b T12-3a T12-3b $\underline{\text { T12-4a }}$ T12-4b

50.8
40.3
32.0
25.4
20.2
16.0
12.7
10.1
8.0
6.4
5.0
4.0

$\begin{array}{rrrrrrr}2.3 & 0.4 & 2.8 & 0.0 & 0.4 & 0.0 & 0.0 \\ 7.2 & 5.3 & 10.9 & 2.4 & 3.6 & 0.0 & 0.1 \\ 16.3 & 15.3 & 23.0 & 9.3 & 10.3 & 1.6 & 1.1 \\ 25.8 & 25.8 & 34.0 & 19.2 & 17.5 & 6.9 & 4.5 \\ 34.3 & 35.1 & 43.2 & 29.1 & 23.6 & 15.0 & 9.8 \\ 41.3 & 42.9 & 50.5 & 37.3 & 27.3 & 22.4 & 15.1 \\ 46.1 & 48.2 & 55.5 & 42.9 & 29.6 & 28.2 & 19.5 \\ 50.0 & 52.5 & 59.7 & 47.2 & 31.0 & 32.4 & 23.0 \\ 53.2 & 56.0 & 63.2 & 50.6 & 31.8 & 35.4 & 25.6 \\ 55.7 & 59.1 & 66.1 & 53.3 & 32.3 & 37.5 & 27.4 \\ 56.6 & 60.3 & 67.1 & 54.4 & 32.3 & 38.3 & 28.2 \\ 57.0 & 61.1 & 67.9 & 55.0 & 32.3 & 38.9 & 28.6\end{array}$




\section{DISTRIBUTION}

No. of

Copies

OFFSITE

10 DOE/Office of Scientific and Technical Information

Villian Ayres

Pyrotech, Inc.

8016 Stateline

Suite 101

Leawood, KS 66208

6 Suresh Babu

Institute of Gas Technology

IIT Center

3424 South State Street

Chicago, IL 69616

Phillip Badger

Bionass Fuels Progran

Tennessee Valley Authority

Muscle Shoals, NL 35860

Millian Bair

Institute of Gas Tochnology

IIT Center

3424 South State Street

Chicago, IL 66616

David Bancroft

Council of Great Lakes

Covernors

122 West Washington Ave., $1801 \AA$

Madison, WI 63763

David S. Backner

Office of Solid Waste and

Renewable Resources

Illinois Department of Energy and Natural Resources

326 W. Adans St., Roon 360

Springfiold, IL 62704-1892

K. Durai-Swany

Managenent and Technical

Consultants, Inc.

13680 Park Street

Santa Fe Springs, CA 96670

Robert Evans

Institute of Gas Technology

IIT Conter

3424 South State Streot

Chicago, IL 60616

Herman F. Feldanan

Battol le-Col unabus

Laboratories

505 King Avenue

Coluabus, OH 43201
No. of

Copies

Virgil J. Flanigan

Univ. of Missouri-Rolla

223 Engineering Research Lab.

Rolla, MO 65401

Patrick Fox

Pacific Northwest and Alaska Bioenergy Progra

Bonneville Power

Adninistration

Routing, EPG

U.S. Department of Energy

P.0. Box 3261

Portland, OR 97268

4 Sinon Friedrich

Biofuels and Municipal Waste Technology Division

U.S. Department of Energy

Forrestal Building (CE-341)

1600 Independence Avenue

Washington, D.C. 26586

Robert Gyllenborg

Southwest Regional Bionass

Energy Progran

Western Area Power Authority

P. O. Box 3462

Colden, CO 89461

Barbara Coodanan

Solar Energy Research

Institute

1817 Cole Blyd.

Colden, CO 80401

John Coss

Departaent of Agricultural

Engineering

2036 Baines $\mathrm{Hall}$

University of California, Dayis

Davis, CA 95816

Michael S. Graboski

Syngas Systens Inc.

P. 0. Box 757

Colden, CO 86462-0757
No. of

Copies

aues E. Helt

Chen ical Engineer

Argonne National Laboratory

Building 205

9706 S. Cass Avenue

Argonne, IL 66439

v. Densnore Hunter, Manager Energy Technology Department Weyerhaeuser Company

VTC-1B-38

Tacoma, WA 98477

James D. Kerstetter Mashington State Energy Office

State of Washington 869 Legion Yay S.E. ER-11

Olyapia, WA 98504-1211

Donald L. Klass

Institute of Gas Technology

IIT Conter

3424 South State Street

Chicago, IL 68616

Richard Knight

Institute of Gas Technology IIT Center

3424 South State Street

Chicago, IL Bg618

Janes Kuester

Dept. of Chen. Engineering

Arizona State University

Teape, NZ 85281

Ronald Loose, Director

Office of Renewable Technology

U.S. Departnent of Energy

Forrestal Building

1000 Independence Arenue

Washington, D.C. 26585

Parker D. Mathusa

Progran Director

New York State Energy Research

and Developaent Authority

2 Rockefeller Plaza

Albany, NY 12223 
No. of

Thonas R. Miles, Sr.

Consulting Design Engineers

5475 S.II. Arrowwood Lane

Portland, OR 97225

Terrance R. Miller, Manager

Office of Solid Waste and

Renewable Resources

Il ino is Dept. of Energy 4

Natural Resources

325 V. Adans, Roon 390

Springfield, IL 62704-1892

Thomas A. Milne

Solar Energy Research Inst.

1617 Cole Blvd.

Golden, CO 86461

Russe II D'Connel I

Northwest Regional Bionass

Energy Progran

Coalition of Northeastern

Governors

406 N. Capital St., Ni",

Suite 38

Washington, D.C. 20001

Nichael Dnischak

Institute of Gas Technology

IIT Center

3424 South State Streot

Chicago, IL 66616

Mark Paisley

Battel le-Colunbus

Laboratories

595 King Arenue

Colunbus, DH 43281

Thomas Reed

Department of Engineering

Colorado School of Mines

Colden, CO BQ461

Coorge Simons

California Energy Connission

1516 - 9th Street, MS-43

Sacranento, CA 9581

Stan loy Sobczynaki

Division of Improved Energy Productivity

U.S. Departinent of Energy

Forrestal Building CE-142

1600 Independence Avenue

Washington, DC 26585

C. Edward Taylor

Corporate Energy \& Env. Mgr.

Louisiana-Pacific Corporation

P.D. Box 158

Sanoa, CA 95564
No. of

Copies

Carl J. Wallace

Solar Energy Research

Institute

5109 Leesburg Pike,

Suite 414

Falls Church, VA 22041

Donald K. Nalter, Director Biofuels and Municipal Waste Technology Division

U.S. Department of Energy Forrestal Building (CE-341)

1006 Independence Avenue

Washington, D.C. 29585

Edward I. Wan

Science Applications

International Corporation

1710 Goodridge Drive

McLean, VA 22162

\section{Ed Wood}

Energetics, Inc

9219 Route 168

Columbia, MD 21045

Richard C. Wright

Energy Research Associates

2115 \%. Norfolk

Wequon, NI 53892

FOREIGN

Tony Bridgwater

The University of Aston in Birninghan

Dept. of Chenical Engineering

Costa Green

Birninghan

ENGAND B4 7ET

\section{DNSITE}

DOE Richland

Dperations office

D. R. Segna

19 Pacific Northwest Laboratory

E. G. Baker

M. A. Gerber

R. J. Hall

L. K. Mudge

G. F. Schiofelboin (5)

L. J. Sealock

D. J. Stevens

P. C. Malkup

Publishing

Coordination (2)

Technical Report Files (5) 